UNIVERSIDADE DE SÃO PAULO

INSTITUTO DE GEOCIENNCIAS

\title{
SELEÇÃO DE SIITIOS VISANDO A IMPLANTAÇÃO DE ATERROS SANITÁRIOS COM BASE EM CRITÉRIOS GEOLÓGICOS, GEOMORFOLÓGICOS E HIDROLÓGICOS
}

\author{
MARIA CANDIDA BARBOSA DO NASCIMENTO
}

Orientador: Prof. Dr. Uriel Duarte

DISSERTAÇÃO DE MESTRADO

COMISSÃO JULGADORA

Nome

Presidente: Prof. Dr. Uriel Duarte

Examinadores: Prof. Dr. Aristides Almeida Rocha

Dr. Fabio Taioli

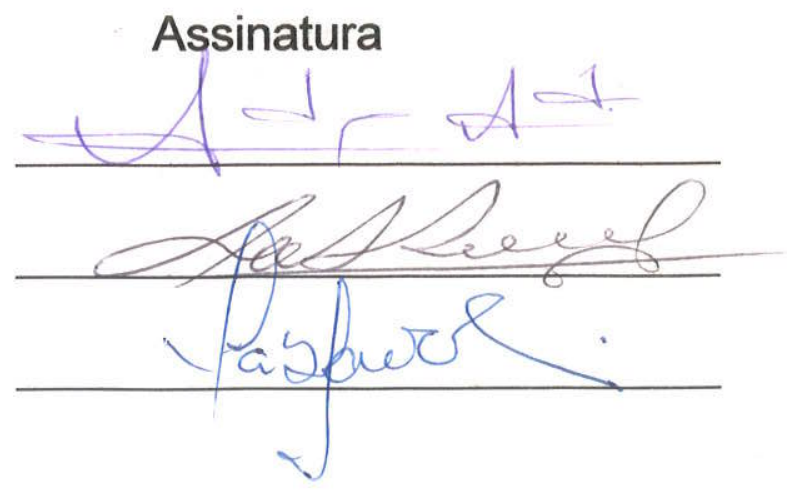

SÃO PAULO

2001 
Universidade de São Paulo

Instituto de Geociências

\section{SELEÇÃO DE SÍTIOS VISANDO A IMPLANTAÇÃO DE ATERROS SANITÁRIOS COM BASE EM CRITÉRIOS GEOLÓGICOS, GEOMORFOLÓGICOS E HIDROLÓGICOS}

Maria Cândida Barbosa do Nascimento

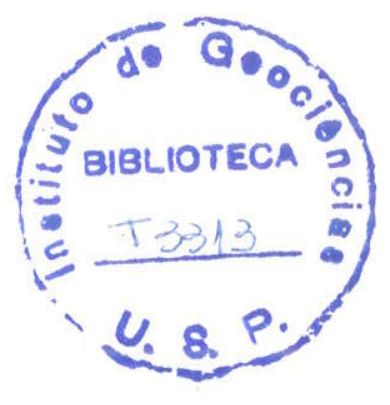

Orientador: Prof. Dr. Uriel Duarte

Dissertação de mestrado

Programa de Pós-Graduação em Recursos Minerais e Hidrogeologia

São Paulo

2001

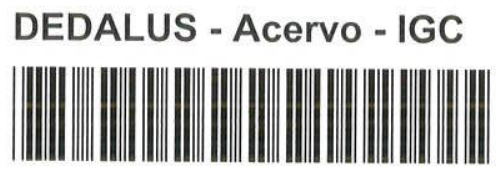

30900006851 


\section{Seleção de sítios visando a implantação de aterros sanitários com base em critérios geológicos, geomorfológicos e hidrológicos}

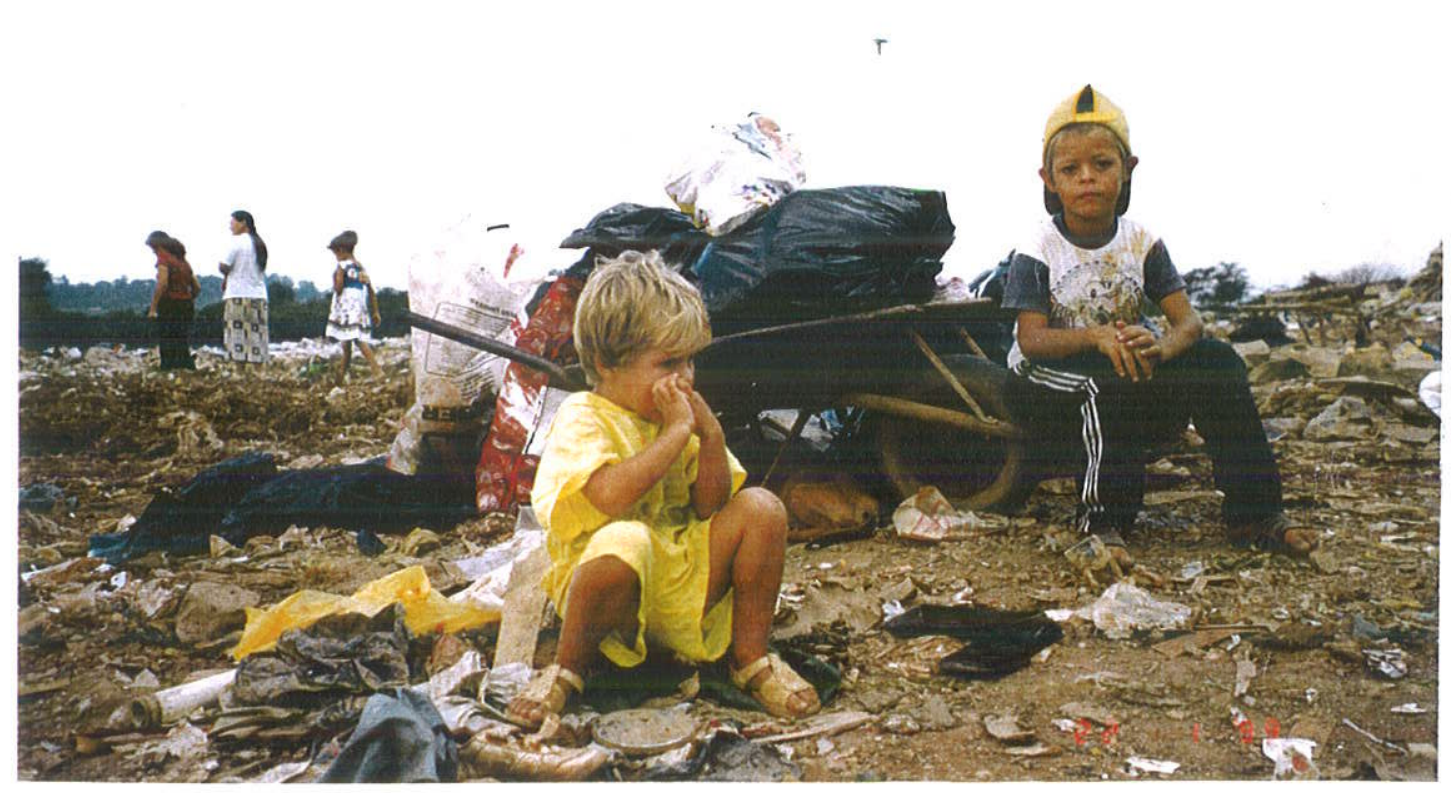

crianças trabalhando no lixão de Atibaia/SP, fevereino de 1999.

"Tălvez nossa reflexão deva comesar por aĩ: pelo fáto de que nossa sobrevivêncią está ameaçada. O novo milênio é apenas uma data no calendârio de uma das grandes religiōes, mas pode ser a ocasiāo para fazermos um balanço. Temos a chave do futuro da humanidade, mas para poder usá-la temos que compreender o presente".

Sebastiāo Salgado 
ao nosso menino Lucas Barbosa Karmann

à prof Maria do Socôrro, minha mãe ao prof Alziro, meu pai 


\section{ÍNDICE}

Índice de figuras

Índice de tabelas

Índice de fotografias

Anexo 1

Resumo

Abstract

Agradecimentos

1 INTRODUÇÃO

1.1. Apresentação 1

1.2. Objetivos 2

1.3. Metodologia 3

2.SELEÇÃO DE ÁREAS PARA ATERROS SANITÁRIOS

2.1. Residuos 5

2.1.1.Definição

2.1.2. Classificação

2.1.3.Composição 6

2.1.4.Processo de decomposição 10

2.1.5. Chorume 12

2.1.6. Migração dos contaminantes e atenuação do seu impacto ambiental 15

2.2. Sítios de disposição de resíduos sólidos urbanos 20

2.3. Critérios relativos ao meio físico para a seleção de áreas para aterros sanitários 24

3.ESTUDO DECASOS

3.1. Municipio de Juiz de Fora (MG)

3.1.1.Caracterização geral do município de Juiz de Fora (MG) 31

3.1.1.1. Geologia 32

3.1.1.2. Geomorfologia 33

3.1.1.3. Cobertura superficial 33

3.1.1.4. Drenagem superficial $\quad 35$

3.1.1.5. Clima $\quad 35$

3.1.1.6. Cobertura vegetal 35

3.1.2.Processo de seleção de áreas para o aterro sanitário em Juiz de Fora (MG) 36

3.1.2.1. Histórico da pesquisa de sítios no município 36

3.1.2. Método utilizado para a seleção de sítios 37

3.1.2.3. Principais características das regiões analisadas 39

3.1.2.4. Seleção final do sítio 44

3.1.3.Caracterização física do sítio Igrejinha $\quad 44$

3.1.3.1. Geologia estrutural 46

3.1.3.2. Condicionamento estrutural da paisagem 49

3.1.3.3. Modelo de circulação da água subterrânea no Sítio lgrejinha 51

3.1.3.4. Aspectos geotécnicos 53

3.1.3.5. Conclusão 53 
3.2. Municipio de llhéus (BA) 54

3.2.1.Caracterização geral do município de llhéus 54

3.2.1.1. Geologia 57

3.2.1.2. Geomorfologia 60

3.2.1.3. Cobertura superficial 62

3.2.1.4. Hidrologia $\quad 62$

3.2.1.5. Clima 63

3.2.1.6. Cobertura vegetal 63

3.2.2.Processo de seleção de sítios para aterro sanitário 64

3.2.2.1. Método utilizado para seleção de sítios 64

3.2.2.2. Principais características dos setores analisados 66

3.2.2.3. Classificação geral dos sítios 86

3.2.2.4. Seleção Final 89

3.2.2.5. Escolha Final do sítio 92

3.2.2.6. Resultado Final 93

3.3. Municipio de São Paulo/SP 93

3.3.1.Caracterização geral do municipio 93

3.3.1.1. Geologia 94

3.3.1.2. Geomorfologia 96

3.3.1.3. Cobertura superficial 98

3.3.1.4. Clima 100

3.3.2.Processo de seleção do aterro São João 100

3.3.2.1. Histórico da pesquisa de sitios no município 100

3.3.2.2. Método utilizado para a seleção de sítios 102

3.3.2.3. Principais características das áreas analisadas 106

3.3.2.4. Seleção Final do sítio 106

3.3.3.Caracterização geral do Aterro Sanitário São João 108

$\begin{array}{lll}\text { 3.3.3.1. Geologia } & 110\end{array}$

3.3.3.2. Geomorfologia 113

3.3.3.3. Cobertura superficial e aspectos geotécnicos 113

$\begin{array}{ll}\text { 3.3.3.4. Hidrogeologia } & 113\end{array}$

$\begin{array}{ll}\text { 3.3.3.5. Águas superficiais } & 115\end{array}$

$\begin{array}{ll}\text { 3.3.3.6. Pluviosidade } & 116\end{array}$

3.3.4. Monitoramento ambiental $\quad 116$

3.3.4.1. Análise das águas superficiais 117

3.3.4.2. Análise das águas subterrâneas 122

4.CONCLUSÕESERECOMENDAC̄ÕES 127

5.REFERENNCIAS 131 


\section{INDICE DE FIGURAS}

Figura 2.1 Evolução do volume de resíduos urbanos coletados no Município de São Paulo (1978-1998).

Figura 2.2 Evolução dos componentes principais dos residuos urbanos coletados no Município de São Paulo (1978-1998)

Figura 2.3 Evolução dos componentes secundários dos resíduos urbanos coletados no Municipio de São Paulo (1927 -1998)

Figura 2.4 Comportamento de alguns parâmetros físicomquímicos durante o processo de decomposição de resíduos municipais. Adaptado de Stanforth et al. (1979).

Figura 2.5 Caminhos de escoamento, infiltração e percolação de águas superficiais no aterro de resíduos (Adaptado de Leckie, et al., 1979)

Figura 3.1 Localização geral do município de Juiz de Fora (MG).

Figura 3.2 Geologia do município de Juiz de Fora (MG). Adaptado de Nogueira, 1999.

Figura 3.3 Zoneamento ambiental do municipio de Juiz de Fora (MG) visando a

Figura 3.4 Projeção estereográfica das medidas estruturais do sítio Igrejinha

Figura 3.5 Mapa de fotolineamentos do sítio Igrejinha

Figura 3.6 Histograma de fotolineamentos do Sítio Igrejinha. (obs: as feições lineares representam linhas de cristas e fundos de vales).

Figura 3.7 Localização geral do município de lihéus (BA).

Figura 3.8 Geologia do município de llhéus (BA).

Figura 3.9 Geomorfologia do município de lihéus (BA).

Figura 3.10 Zoneamento ambiental do município de llhéus visando a implantação de aterros sanitários (Adaptado de Conder/Equipe Umah, 1997).

Figura 3.11 Localização geral do Município de São Paulo (SP)

Figura 3.12 Geologia do Município de São Paulo (SP). (Adaptado de Rodriguez, 1998).

Figura 3.13 Distribuição da ocupação no Município de São Paulo(SP). Imagem extraída de www.prodam.sp.gov.br/svma/atlasamb/index.htm)

Figura 3.14 Localização dos sítios analisados no Município de São Paulo (SP). Adaptado de LIMPURB/Equipe Umah, 1990).

Figura 3.15 Localização e principais vias de acesso do aterro sanitário São João, São Paulo. 
Figura 3.16 Localização dos pontos de amostragem das águas superficiais do aterro sanitário São João (Adaptado de Enterpa, 1999)

Figura 3.17 Planta do aterro sanitário São João - Localização dos poços de monitoramento (Adaptado de Epal, 1998).

Figura 4.1 Etapas de investigação e processos decisivos com relação ao meio físico na prospecção e seleção de sítios para aterros sanitários

\section{ÍNDICE DE TABELAS}

Tabela 2.1 Classificação dos resíduos urbanos gerados em diferentes cidades do mundo Extraído de Carra e Corru, 1990, DEMLURB/Equipe Umah, 1995; Conder/Equipe Umah, 1997; Orth e Motta, 1998 e Calderoni, 1999.

Tabela 2.2 Evolução do volume de resíduos coletados no Município de São Paulo. Extraído de Calderoni, 1999 e Orth e Motta, 1998

Tabela 2.3 Evolução da variação dos componentes presentes nos resíduos urbanos coletados no Município de São Paulo ( 1927 - 1998). Extraído de Orth e Motta, 1998.

Tabela 2.4 Exemplos da composição física-química-bacteriológica de alguns chorumes provenientes de resíduos sólidos urbanos. Adaptado de Robison e Maris (1979), Qasim e Chiang (1994), Tressolti e Consoni (1998), Enterpa (1999).

Tabela 2.5 Evolução da composição do chorume em aterros sanitários, segundo Chian e DeWalle (1976, 1977a).

Tabela 2.6 Relação entre o tamanho das partículas, permeabilidade de solos e respectivas capacidade de proteção das águas subterrâneas, visando a implantação de aterros sanitários. Adaptado de U. S. EPA (1978) e Qasim e Chiang (1994)

Tabela 2.7 Destino dos resíduos em diferentes países, expressos em porcentagem do total de resíduos produzidos (SMA/SP, 1998; Carra e Cossu, 1990).

Tabela 2.8 Depósitos abertos, depósitos controlados e aterros sanitários

Características básicas, vantagens e desvantagens. Adaptado de IETC (1996).

Tabela 2.9 Principais fatores do meio físico e seus respectivos graus de limitação a serem considerados na escolha de sítios para aterros sanitários. Adaptado de O'Leary et. al. (1986), Pfeffer (1992) e Tchobanoglous et. al. (1993).

Tabela 2.10 Principais critérios para avaliação preliminar de locais para disposição de residuos, segundo IPT/CEMPRE (1995) e Tressolti e Consoni (1998).

Tabela 2.11 Potencialidade relativa dos compartimentos na RMSP para disposição final de resíduos. Adaptado de Hicsan-Etep (1994)

Tabela 3.1 Síntese dos sítios analisados (Adaptado de Demlurb/Equipe Umah, 1995).

Tabela 3.2 Medidas estruturais do Sítio Igrejinha (em relação ao Norte Geográfico) 
Tabela 3.3 Síntese dos sítios analisados no município de llhéus (BA).

Tabela 3.4 Indicadores e critérios utilizados para hierarquização dos sítios. Dados extraídos de Conder/Equipe Umah (1997)

Tabela 3.5 Pontuação e hierarquização dos sítios selecionados. Extraído de

Tabela 3.6 Parâmetros utilizados para a avaliação de impacto ambiental durante o processo de seleção de sítios no Município de São Paulo Adaptado de Limpurb/ Equipe Umah, 1990.

Tabela 3.7 Principais características dos sítios analisados no Município de São Paulo (Adaptado de Limpurb/Equipe Umah, 1990).

Tabela 3.8 Principais características físico-químicas das águas subterrâneas na área do aterro. Adaptado de Equipe Umah (1990)

Tabela 3.9 Dados analíticos da água superficial do aterro sanitário São João (Adaptado de Enterpa, 1998, 1999 e 2000).

Tabela 3.10 Padrões nacionais e internacionais de potabilidade da água. Adaptado de Cetesb (1974) e Cetesb (1990).

Tabela 3.11 Dados analíticos da água subterrânea do aterro sanitário São João (Extraído de Epal, 1997 e Enterpa 1999 e 2000)

\section{ÍNDICE DE FOTOGRAFIAS}

Foto 1 Vista parcial da mancha urbana do município de Juiz de Fora. Nota-se a região da planície do Rio Paraibuna densamente ocupada. No fundo, ocupação seguindo em direção ao domínio dos morros e morrotes.

Foto 2 Corte na rodovia BR 267 próximo a mancha urbana de Juiz de Fora (MG). Relevo de morrotes e morros arredondados com manto intempérico de espessura extremamente variável e grandes matacões e maciços de esfoliação esferoidal.

Foto 3 Vista geral do lixão Matias Barbosa, área de disposição dos resíduos municipais e de saúde gerados por Juiz de Fora. Nota-se a disposição inadequada dos resíduos.

Foto $4 \quad$ Vista geral do relevo da área da Fazenda Limeira.

Foto $5 \quad$ Vista geral dos anfiteatros em cabeceira de drenagem.

Foto 6 Vista dos vales com fundo plano (vales de agradação) tipicos da região

Foto 7 Detalhe do amplo anfiteatro em cabeceira de drenagem com vertentes de inclinação moderada

Foto $8 \quad$ Vale aberto com fundo plano adjacente ao sítio Igrejinha

Foto 9 Anfiteatro do sítio Igrejinha selecionado para o aterro. Notar a inclinação moderada das vertentes e a grande área do anfiteatro. 
Foto 10 Vista frontal do anfiteatro selecionado para o aterro do sítio Igrejinha.

Foto 11 Relevo de cristas e morros arredondados com amplos anfiteatros em cabeceiras de drenagens na área do sitio Igrejinha.

Foto 12 Vista parcial da área de empréstimo do aterro sítio Igrejinha.

Foto 13 Vista do tipo de ocupação do vale do sítio Igrejinha.

Foto 14 Margem esquerda do Córrego Igrejinha, nas proximidades da área selecionada. Afloramento exibindo as fraturas de cisalhamento dúctil-rúptil inclinadas obliquamente a foto e o bandamento gnáissico sub-horizontal .

Foto 15 Aspecto típico dos gnaisses da região do sítio lgrejinha com grandes maciços de esfoliação esferoidal semi-aflorantes.

Foto 16 Vista aérea da cidade de llthéus e da desembocadura do Rio Cachoeira no mar.

Foto 17 Lixão do Cururupe. Área de disposição dos resíduos gerados no município de Ilhéus. Localizado na planície aluvionar do Rio Cururupe

Foto 18 Moradora da área do lixão lavando seus utensílios nas águas contaminadas pelo chorume.

Foto 19 Vista aérea do Setor Sul de llhéus exibindo as áreas drenadas pelas bacias costeiras e a bacia do Rio Cururupe. No centro, estrada de acesso à Buerarema. A esquerda, pedreira em granulitos básicos do embasamento.

Foto 20 Vista aérea do sítio Embasa. Anfiteatro de cabeceira de drenagem ocupado pela mancha de vegetação no centro da foto. Morfologia de morros com topos aplainados. A direta estrada não pavimentada sentido Buerarema.

Foto 21 Areal. Cava de extração de areia. Ocorrência de areias pouco consolidadas ao longo dos taludes escavados.

Foto 22 Em primeiro plano, planície aluvionar do Rio Cururupe com disposição de resíduos. No fundo, morros testemunhos do embasamento cobertos pelo Grupo Barreiras.

Foto 23 Alagamento na planície do Rio Cururupe causado pelo acúmulo de resíduos.

Foto 24 Área fazenda Omologi. Morros de topos aplainados com dois anfiteatros semicirculares amplos e declividade moderada.

Foto 25 Fundo de vale junto a anfiteatro da área acima, com afloramento do embasamento rocoso. Nascente de água no contato solo/rocha, originando pequeno córrego.

Foto 26 Área Fazenda Arabela. Vista no sentido jusante de um dos anfiteatros. Ao fundo, represamento artificial junto a drenagem principal da área.

Foto 27 Ponte do Banco da Vitória, sobre o Rio Cachoeira. Única travessia que interliga os setores Norte e Sul do município de llhéus 
Foto $28 \quad$ Vista geral da área Maria Jape I. Anfiteatro com vertentes suaves e represamento no fundo do vale.

Foto 29 Área Itariri. Anfiteatro de cabeceira de drenagem com vertentes de inclinação média-alta (centro da foto).

Foto $30 \quad$ Vertente do anfiteatro com afloramentos de gnaisse e metabásicas

Foto 31 Captação de água a jusante do anfiteatro para abastecimento local.

Foto 32 Aterro sanitário São João. No fundo, antiga área de disposição. Em primeiro plano, frente de disposição em 1999.

Foto 33 Vista lateral do aterro. Nota-se o anfiteatro preenchido através de células de resíduos. Na vertente esquerda, nota-se a impermeabilização com manta

Foto $34 \quad$ Vista do vale do Córrego Floresta com planície aluvial ocupada por lagoas de chorume.

Foto 35 Corte na vertente do anfiteatro exibindo micaxistos alterado com lentes de quartzito.

Foto 36 Vertente esquerda do aterro com corte de talude em micaxisto e manta de impermeabilização.

Foto 37 Poço de coleta de chorume. Ao fundo, células de disposição com canalização de nascentes e escada para escoamento das águas pluviais.

Foto 38 Detalhe do poço de captação do chorume.

Foto 39 Poço de monitoramento de águas subterrâneas situado a montante do aterro, no limite Leste

\section{Fotos aéreas}

Vista aérea da Fazenda Limeira

Vista aérea do Sítio Igrejinha

Anexo 1 - Dados analíticos da água subterrânea do aterro sanitário São João, São Paulo (SP). (Epal 1997, Enterpa 1999a e 2000a) 


\section{RESUMO}

A disposição de resíduos sólidos urbanos, principalmente nas grandes metrópoles, tornouse um dos principais problemas da administração pública e da sociedade em geral.

Mundialmente, nos países desenvolvidos e naqueles em desenvolvimento, a principal forma de disposição dos resíduos urbanos é em aterros sanitários e aterros descontrolados, respectivamente. Com exceção dos paises essencialmente urbanizados, como o Japão que encaminha somente $20 \%$ do total de resíduos gerados, a Suíça $12 \%$, Suécia $35 \%$ e a Dinamarca $31 \%$. Países como a Alemanha, Holanda e França encaminham em média $50 \%$ do volume gerado. A Itália, Reino Unido, Noruega, Áustria, Estados Unidos e África do Sul encaminham taxas superiores a $60 \%$. Canadá, Polônia e Brasil encaminham praticamente $100 \%$ dos resíduos urbanos gerados.

No Estado de São Paulo, dentre os 643 municípios, $324(50,4 \%)$ lançam seus resíduos na forma de lixão, $136(21,1 \%)$ em aterros controlados e apenas $183(28,5 \%)$ em aterros sanitários.

É de consenso geral que a tendência a curto e médio prazo para a disposição de resíduos urbanos continuará sendo na forma de aterros sanitários, principalmente nos países com disponibilidade em área. Trata-se de um método relativamente econômico, de tecnologia amplamente conhecida e eficiente quanto à proteção do ambiente natural, se obedecidos os critérios para a seleção de áreas, implantação e operação e encerramento das atividades.

Os sítios de deposição de resíduos que operam inadequadamente vem diminuindo no mundo. Por outro lado, eles estão se tornando bem maiores e estão sendo operados com tecnologias muito mais sofisticadas.

A principal proposta desta pesquisa é de contribuir no estabelecimento e divulgação de critérios geológicos, geomorfológicos e hidrológicos a serem adotados para a seleção de sítios para aterros sanitários, pois sabe-se que a locação de sítios é uma das etapas mais difícies e complexas do gerenciamento de resíduos sólidos.

A primeira parte desta pesquisa buscou atingir os principais temas relacionados direta e indiretamente a disposição de resíduos e suas principais interferências com o meio físico, destacando-se a poluição do solo e conseqüente poluição das águas superficiais e subterrâneas ocasionada pelo chorume, produto de decomposição dos resíduos. Os temas abordados se relacionaram a definições e discussões à respeito das diversas classificações de resíduos sólidos, seus principais produtos de decomposição, os mecanismos de migração para as águas subterrâneas, suas principais formas de disposição no solo, e os diferentes métodos utilizados para a seleção de sítios.

O principal objetivo da pesquisa foi o estudo de casos, onde os procedimentos de seleção de sítios foram avaliados em municípios que sofreram o processo de escolha de áreas para aterros sanitários. Como estudos de casos foram discutidos os processos de seleção dos municípios de Juiz de Fora/MG, lihéus/BA e São Paulo/SP. 
A partir destes exemplos concluiu-se que a situação fisiográfica ideal, é a de anfiteatros amplos (com baixa a média declividade), em cabeceiras de drenagem, desenvolvidas sobre rochas pouco permeáveis (com baixa porosidade primária e/ou secundária) e com espessas coberturas de material rico em argilo-minerais. Portanto, a prospeção de locais favoráveis para deposição de resíduos sólidos (neste caso, domésticos), envolve a análise geomorfológica e hidrográfica dos municípios, procurando áreas de divisores de água em cotas altas, seguida pela investigação geológica do substrato rochoso e do seu material de cobertura. O material rochoso deve ser caracterizado quanto à sua natureza (identificação litológica) e, principalmente, com relação à sua porosidade e permeabilidade, o que requer a caracterização estrutural da rocha (identificação e mapeamento de descontinuidades, como porosidade primária, planos de estratificação, fraturas e falhas).

Para testar a eficácia dos procedimentos de seleção e a posterior operação, foi escolhido o aterro sanitário São João, situado no município de São Paulo, que está em operação desde dezembro de 1992. Apesar deste aterro ter sofrido processo seletivo de áreas seguindo critérios técnicos, os dados de monitoramento das águas superficiais e subterrâneas mostram que a operação deste aterro afetou a qualidade destas águas. 


\section{ABSTRACT}

The disposal of domestic solid waste is becoming one of the biggest problem of the public administration and of the society in general.

Both in developed and in development countries, the main method of waste disposal is still in sanitary landfills and controlled fills, with exception of high urbanized countries, like Japan, Switzerland, Sweden and Denmark, where only 20,12, 35 and 31\%, respectively, of the total produced waste is disposed in sanitary landfills.

Countries like Germany, Holland and France dispose in average $50 \%$ of their total waste in landfills. Italy, UK, Nomay, Austria, USA and South Africa dispose more than $60 \%$ of the total urban domestic waste in landfills.

In São Paulo State, between 643 towns, $324(50,4 \%)$ dispose their waste in uncontrolled landfills, $136(21,1 \%)$ in controlled landfills and only $183(28,5 \%)$ in sanitary landfills.

It is of common sense today that in the next future the disposal of urban waste will be mainly in sanitary landfills, especially in countries which have plenty of land. It is still a economic way of disposal, with a very well known and efficient technology with respect to the protection of the natural environment, if the criteria of siting, construction, operation and site restoration are followed.

The number of not well installed disposal sites is decreasing around the world. On the other side, the landfills are increasing in size and their operation is requiring higher technologies.

One of the main goals of this research was to contribute in the establishment of geological, geomorphological and hydrological criteria to be followed for the siting process of sanitary landfills, considering that the location of landfill sites is one of the hardest and most complex tasks during the management of urban waste.

In the first pant of this research a discussion and a synthesis based on published data about the interference of waste disposal in the environment is presented, emphasizing the soil contamination and the consequently surface and groundwater pollution caused mainly by the leachate, a product of the waste decomposition. Several classifications of solid residues are discussed including the different kinds of disposal techniques and their environmental implications and requirements.

The main proposal of this research was the case study of the siting processes which were developed for the municipalities of Juiz de Fora (Minas Gerais state), Ihéus (Bahia State) and São Paulo (São Paulo state). For each case the criteria and the procedures related to the siting are presented and discussed.

Based on the above examples, it was concluded that the ideal physiographic situation for landfills is that of broad topographic arcs, close to the edge of watersheds, developed over low permeability rocks (with low primary and/or secondary porosity) or over thick soil covers rich in clay minerals. Therefore, the siting in the above towns involved geomorphological mapping and drainage 
analysis examining water divides in high topographic locations followed by the analysis of the lithology and soil cover. With respect to the bedrock examination, emphasis has been giving to the identification of discontinuities like bedding planes, fractures and faults.

The São João landfill in São Paulo City has been selected in onder to test the efficiency of the siting process and the later operation. Despite the location of this landfill followed several technical criteria, the monitoring of surface and groundwater quality has shown that the operation of this landfill strongly affected the quality of the water. 


\section{AGRADECIMENTOS}

Ao meu orientador Prof $^{\circ}$ Dr. Uriel Duarte pela amizade, incentivo e apoio dedicado na execução deste trabalho.

A Fundação de Amparo à Pesquisa do Estado de São Paulo (FAPESP, Proc ${ }^{\circ}$ 98/01438-8) pelo auxílio financeiro que viabilizou a realização desta dissertação.

Ao Prof ${ }^{\circ}$ Dr. Ivo Karmann que me acompanhou durante os trabalhos de campo auxiliando nos mapeamentos geológicos. Agradeço profundamente seu companherismo e dedicação por todos esses anos de convivio.

A Equipe Umah, em especial ao amigo Ubirajara Pereira Fontes e ao engenheiro Mauricio Adeodato Boaventura por terem possibilitado meu avanço na área de planejamento ambiental, e pela experiência no convívio e do aprendizado que foram fundamentais à minha formação profissional.

A Companhia de Desenvolvimento Urbano do Estado da Bahia/Conder, em especial a Coordenadora de Planejamento e Qualidade Ambiental Maria de Fátima Torreão Espinheira, pelo apoio e pela disponibilidade de informações técnicas.

Aos técnicos da Prefeitura Municipal de Ilhéus, em especial a engenheira Regina Leite de Farias pelo apoio nos trabalhos de campo.

Agradeço a Prefeitura Municipal de Juiz de Fora (MG), ao Departamento de Limpeza Urbana de Juiz de Fora, MG/ Demlurb, e ao Departamento de Limpeza Urbana do Município de São Paulo/Limpurb pelas informações obtidas.

Ao engenheiro Francisco J.P. de Oliveira pela colaboração na obtenção de dados.

A equipe multidisciplinar que participou no processo de seleção de sítios, em especial ao engenheiro florestal e agrônomo Wandir Ribeiro, a bióloga Silvia Fazzolari Correa, ao economista Raul de Carvalho, aos sociólogos César Oller do Nascimento e Mariana de Souza Fontes, e a historiadora Regina Duarte Orsi.

As minhas irmãs Cássia e Vânia, ao meu irmão Alziro e ao Humberto, pela amizade e carinho até hoje recebidos.

A todos os colegas, docentes e funcionários do Instituto de Geociências da USP, que direta ou indiretamente tiveram sua participação na realização deste trabalho. 


\section{INTRODUÇÃO}

\subsection{Apresentação}

A geração e conseqüente disposição dos resíduos sólidos urbanos, principalmente nas grandes metrópoles, tornou-se um dos principais problemas da administração municipal e da sociedade em geral.

Um exemplo típico é o da Região Metropolitana de São Paulo - RMSP, com uma área total de $8.051 \mathrm{~km}^{2}$ que abriga o maior núcleo urbano do país e o terceiro do mundo, com uma população superior a 17 milhões de habitantes. Além disto, praticamente metade da sua área encontra-se protegida pela Lei de Proteção dos Mananciais, restando com isso, poucas opções de áreas para a disposição de aproximadamente 16.000 toneladas de residuos urbanos gerados diariamente (Cetesb, 1998).

A disposição de resíduos sólidos envolve a poluição do meio ambiente, destacando-se a deterioração da qualidade das águas superficiais e subterrâneas, o problema da limitação de espaços disponíveis nas grandes metrópoles, a capacidade limitada dos sítios em operação, a perda de recursos naturais valiosos, e a oposição da opinião pública na escolha de sitios, amplamente conhecida como "síndrome" NIMBY - Not In My Back Yard (não no meu quintal).

A nível mundial, o principal método de disposição de resíduos sólidos urbanos é através de aterros sanitários, aterros controlados ou não. Muitas áreas foram contaminadas pelo descontrole total do lançamento de resíduos sobre o solo. Nos Estados Unidos, no fim da década de 80, aproximadamente $20 \%$ das ações movidas pela agência ambiental americana (EPA .. Environmental Protection Agency) se referia a limpeza de sitios contaminados por resíduos.

De acordo com Carra e Cossu (1990), o número de sítios de deposicão que operam inadequadamente vem diminuindo no mundo. Nos Estados Unidos, no período de 1978 a 1988 o número de sítios diminuiu de 20.000 para 6.000 unidades. Por outro lado, eles estão se tomando bem maiores e estão sendo operados com tecnologias muito mais sofisticadas.

Segundo o artigo publicado no jornal O Estado de São Paulo, 09/12/97, nos países desenvolvidos a principal maneira de disposição de resíduos é por aterros sanitários, com exceção do Japão que encaminha somente $20 \%$ do total de resíduos gerados; a Suiça, $12 \%$, Suécia, $34 \%$ e a Dinamarca $29 \%$. Tratam-se de países essencialmente urbanizados, que além de adotarem a incineração, apresentam uma política atuante na reciclagem e reutilização dos resíduos. Países como a Holanda, Alemanha, França encaminham em média $50 \%$ do volume gerado. A Itália, Reino Unido, Noruega, Áustria e Estados Unidos apresentam taxas superiores a $60 \%$.

No Brasil, é relativamente recente a discussão e a conscientização da necessidade do planejamento e gerenciamento dos residuos, principalmente no que tange a seleção de sítios para aterros sanitários através de critérios técnicos e ambientalmente viáveis. Hoje, apesar da existência de dispositivos legais rígidos, a situação encontra-se extremamente crítica, parte devido a falta de 
recursos financeiros, e parte pela inexistência de uma política atuante na gestão e gerenciamento dos resíduos sólidos.

O jornal a Folha de São Paulo de 10/05/2000 publica Mais de 600 crianças vivem do lixo em SP. O artigo menciona o trabalho destas crianças nos lixões e que no ano de 1997, o estado de São Paulo lançava seus resíduos na forma de lixão em 502 municípios, o que correspondia a $78 \%$ do total.

Hoje, apesar dos índices serem mais promissores, ainda deixam a desejar, pois conforme a manchete da Folha de São Paulo de 08/01/2001, metade dos municípios de São Paulo ainda usam lixões, índice revelado pela Cetesb. De 643 municípios que compóe o estado, $324(50,4 \%)$ lançam seus resíduos na forma de lixão, $136(21,1 \%)$ na forma de aterros controlados, e apenas $183(28,5 \%)$ na forma de aterros sanitários.

No Brasil e em diversos paises, onde existem espaços disponiveis, a tendência a curto e médio prazo para a disposição de resíduos sólidos urbanos será na forma de aterros sanitários, uma vez que trata-se de um método relativamente econômico, de tecnologia amplamente conhecida e eficiente quanto à proteção dos recursos naturais, se obedecidos os critérios para seleção de áreas, implantação, operação e encerramento das atividades. A esta tendência soma-se o incentivo à política de reciclagem e reutilização dos resíduos, que vem de encontro ao aumento da vida útil destes aterros. Calderoni (1999) conclui que a reciclagem do lixo é economicamente viável no Município de São Paulo e no Brasil, pois não reciclar significa deixar de auferir rendimentos da ordem de bilhões de reais todos os anos.

Diante deste quadro, é óbvia a urgente necessidade de solucionar essa questão, seja devido a proteção do solo e dos recursos hídricos, como também, pela proteção da saúde das inúmeras famílias que sobrevivem da coleta de resíduos nos inúmeros lixões espalhados pelo mundo.

A principal proposta desta pesquisa é contribuir no estabelecimento e divulgação de critérios físicos (geológicos, geomorfológicos e hidrológicos) a serem adotados para a seleção de sitios para aterros sanitários, uma vez que a locação de sítios é uma das etapas mais difíceis e complexas do gerenciamento de resíduos sólidos.

\subsection{Objetivos}

Conforme apresentado acima, a situação da disposição de resíduos no Brasil em geral ainda é bastante crítica, e ó principal objetivo desta pesquisa visa contribuir nesta questão, através da discussão e do estabelecimento de critérios físicos a serem adotados no processo de escolha de sítios para a implantação de aterros sanitários. 
A aplicabilidade deste procedimento será avaliada em situações de municípios que já sofreram o processo de escolha de sítios para aterros sanitários, e em ocasióes distintas, tendo como finalidade tentar avaliar os diferentes métodos adotados ao longo da última década.

Como estudos de casos, foram escolhidos os processos de seleção de sítios dos municipios de llhéus (Bahia); Juiz de Fora (Minas Gerais) e São Paulo (São Paulo).

Com o objetivo de testar a eficácia de procedimentos de seleção foi escolhido um aterro sanitário em operação para avaliar o impacto sobre as águas superficiais e subterrâneas. Para tal, optou-se pela análise do processo de escolna de área e o monitoramento das águas do aterro sanitário São João, situado na Zona Leste do Município de São Paulo.

O Município de São Paulo foi escolhido por abrigar o maior contingente populacional do pais e pela escassez de áreas disponiveis. A escolha deste sítio para avaliar as condições das águas superficiais e subterrâneas se deu por tratar-se de um dos mais antigos sítios em operação do Brasil, onde foram contemplados estudos de seleção de áreas, elaboração de projetos básico e executivo, além do monitoramento das suas águas. Trała-se de um dos únicos sítios que não apresenta um passivo ambiental de disposição inadequada anteriormente a implantação do aterro sanitário propriamente dito.

O municipio de Juiz de Fora, em Minas Gerais, entrou no presente estudo pelo fato de ser de médio porte e possuir relativamente maior disponibilidade de área para implantar aterros. Ilhéus, na Bahia, foi enfatizado por se tratar de uma zona turística, de médio porte e com grandes porções do município com severas restrições ambientais.

Serão discutidos também os principais conceitos a respeito da definição de resíduos, seus principais componentes, sua forma de disposição e seus principais mecanismos de atenuação no solo, com o objetivo de homogeneizar a nomenclatura utilizada na dissertação, uma vez que estes conceiłos são controversos e pouco esclarecidos na literatura nacional, conforme será abordado no decorrer do capítulo pertinente.

\subsection{Metodologia}

As etapas metodológicas cumpridas para realização do presente estudo foram pesquisa bibliográfica, estudos de casos e trabalhos de campo.

A pesquisa bibliográfica procurou atingir os principais temas relacionados diretamente e indiretamente à disposição de resíduos e suas principais influencias e interações com o meio ambiente, destacando-se a poluição do solo e a conseqüente degradação das águas superficiais e subterrâneas. Abrangeu também o levantamento das principais referências nacionais e estrangeiras à respeito da seleção de áreas para aterros sanitários. Os estudos de casos foram selecionados conforme se mostravam apropriados para cumprir os objetivos propostos pela 
dissertação, que envolveram a seleção de sítios para aterros sanitários nos municípios de llhéus, Juiz de Fora e Säo Paulo, já citados anteriormente.

Foram visitadas quase que a totalidade dos sítios que se mostraram potenciais para a implantação de aterros sanitários em Juiz de Fora e lthéus, com exceção do Município de São Paulo, cujo trabalho de campo foi realizado inteiramente na área do atual aterro em operação. Os trabalhos de campo foram auxiliados através da análise de fotografias aéreas e da cartografia topográfica e geológica existente.

Com o objetivo de avaliar as condições ambientais das águas superficiais e subterrâneas do aterro sanitário São João, em operação desde dezembro de 1992, foram elaboradas planilhas com as análises físico-químicas e bacteriológicas realizadas principalmente pelos laboratórios Puriquima Ltda e Ambiental Laboratórios e Equipamentos Ltda, abrangendo coletas entre os anos de 1992,1993 e 1996 a 2000.

As concentrações dos elementos foram analisadas de acordo com o limite estabelecido para águas potáveis pelas principais normas e leis existentes na bibliografia nacional e estrangeira. Procurou-se analisar as anomalias diagnosticadas de acordo com a composição do chorume do próprio aterro, não fazendo parte desta dissertação, o estudo da pluma de contaminação e a interpretação geoquímica da distribuição de elementos encontrados nas águas superficiais e subterrâneas.

A partir do conhecimento das referências existentes e da análise dos estudos de casos é proposta uma metodologia para ser utilizada em trabalhos que contemplam a escolha de areas para aterros sanitários. A metodologia proposta é fundamentada essencialmente em critérios geológicos, geomorfológicos, geotécnicos e hidrológicos.

O produto final compreendeu a elaboração de um fluxograma teórico que envolve as possibilidades e os passos a serem seguidos desde a fase de prospecção até a instalação de um aterro.

\subsection{SELEÇÃO DE ÁREAS PARA ATERROS SANITÁRIOS}

Como base para o melhor entendimento das análises e discussões apresentadas nos próximos capítulos, serão abordados alguns conceitos adotados no decorrer desta pesquisa, com base em referências bibliográficas. 


\subsection{Resíduos}

\subsubsection{Definição}

Calderoni (1999) menciona que o conceito de lixo e de residuo pode variar conforme a época e o lugar, e que depende de fatores jurídicos, econômicos, ambientais, sociais e tecnológicos.

$\mathrm{Na}$ linguagem corrente, o termo lixo é usualmente utilizado para designar tudo aquilo que não tem mais utilidade, enquanto que resíduo é muito pouco utilizado na linguagem coloquial. $O$ termo resíduo é mais utilizado em estabelecimentos industriais para designar, por exemplo, o que sobra (refugo) do beneficiamento de produtos industrializados.

De acordo com o dicionário da língua portuguesa, lixo é aquilo que se varre de casa, do jardim, da rua, e se joga fora. Coisa e coisas inúteis, velhas, sem valor. Resíduo é aquilo que resta de qualquer substância, resto (Ferreira, 1988).

$\mathrm{Na}$ linguagem técnica, resíduos são definidos como restos das atividades humanas, considerados como inúteis, indesejáveis ou descartáveis. Normalmente encontram-se sob estado sólido e semi-sólidos (IPT/CEMPRE, 1995).

A Norma ABNT NBR 10004/1987 define resíduo sólido como: residuos nos estados sólidos e semi-sólido, que resultam de atividades da comunidade de origem: industrial, doméstica, hospitalar, comercial, agrícola, de senviços e varrição.

A Norma ABNT NBR 8849/1985, define resíduos sólidos urbanos como: residuos sólidos gerados num aglomerado urbano, excetuados os residuos industriais perigosos, hospitalares sépticos, aeroportos e portos.

A utilização do termo resíduos no presente trabalho corresponde exclusivamente aos residuos sólidos urbanos definidos pela norma acima. Säo compostos principalmente por resíduos domiciliares, que são originados à partir de atividades diárias das residências; os comerciais, gerados pelos diversos estabelecimentos comerciais e de serviços (supermercados, lojas, bares, restaurantes, bancos, dentre outros). Incluem os resíduos originados à partir da varrição de rua incluindo as feiras livres, poda de árvores, capina, limpeza de praias.

De acordo com a legislação brasileira, a coleta e destinação destes resíduos é de competência exclusiva do poder público municipal, e seu destino final é dado principalmente sobre o solo, de forma controlada, ou não.

\subsubsection{Classificação}

A classificação nacional usualmente utilizada refere-se a da Norma ABNT NBR $10.004 / 1987$ que classifica os resíduos sólidos quanto aos seus riscos potenciais ao meio ambiente 
e a saúde pública, tendo como principal objetivo disciplinar o manuseio e destinação adequada dos resíduos.

Esta classificação é fundamentada em padrões internacionais de concentrações de elementos reconhecidamente perigosos. A norma classifica os residuos sólidos em três classes:

Classe 1 - Perigosos. Englobam os resíduos que, em função de suas características de inflamabilidade, corrosividade, reatividade, toxicidade e patogenecidade, podem apresentar risco a saúde pública, provocando ou contribuindo para um aumento de mortalidade ou incidência de doenças e/ou apresentar efeitos adversos ao meio ambiente, quando manuseados ou dispostos de forma inadequada.

Classe 11 - Não Inertes. Englobam os que não se enquadram na Classe I - perigosos ou na Classe 111 - inertes. Estes resíduos podem ter propriedades tais como combustibilidade, biodegrabilidade ou solubilidade em água.

Classe III - Inertes. Resíduos sólidos ou mistura de resíduos sólidos que, submetidos ao teste de solubilização não tenham nenhum de seus constiłuintes solubilizados a concentrações superiores aos padrões definidos. Como exemplos destes materiais, pode-se citar rochas, tijolos, vidros e certos plásticos e borrachas que não são facilmente decompostos.

No Brasil, os residuos sólidos urbanos, que incluem os residuos duráveis e não duráveis, compostos por resíduos orgânicos e inorgânicos originados por fontes residenciais, comércio, instituições públicas e privadas não industriais, são usualmente classificados como resíduos da classe II e III, portanto, inertes e não inertes (não perigosos), respectivamente.

\subsubsection{Composição}

A composição e o volume gerado de residuos sólidos urbanos são parâmetros dinâmicos, que variam no tempo e espaço. Dentre os inúmeros fatores que condicionam a qualidade e quantidade dos resíduos gerados em um município, destacam-se: condições climáticas, costumes sociais, renda per capita, densidade populacional, grau de urbanização e industrialização e políticas econômicas (Tabelas 2.1 a 2.3 e figuras 2.1 a 2.3 ).

No geral, os resíduos domiciliares são constituídos essencialmente por compostos orgânicos (restos de alimentos), papel, papelão, jomais, revistas, garrafas, latas, papel higiênico, fraldas descartáveis, embalagens plásticas, lâmpadas fluorescentes, pilhas, baterias, frascos de aerossóis, tintas e solventes (Tabela 2.1).

Os comerciais são constituídos predominantemente por papel, plástico, vidros em geral e restos de alimentos (mercados). Os demais resíduos (varrição, feiras livres, capina) são compostos por restos vegetais diversos e embalagens diversas (alumínio, papel, papelão, dentre outros). Notase que no Brasil os resíduos são principalmente compostos por matéria orgânica. 


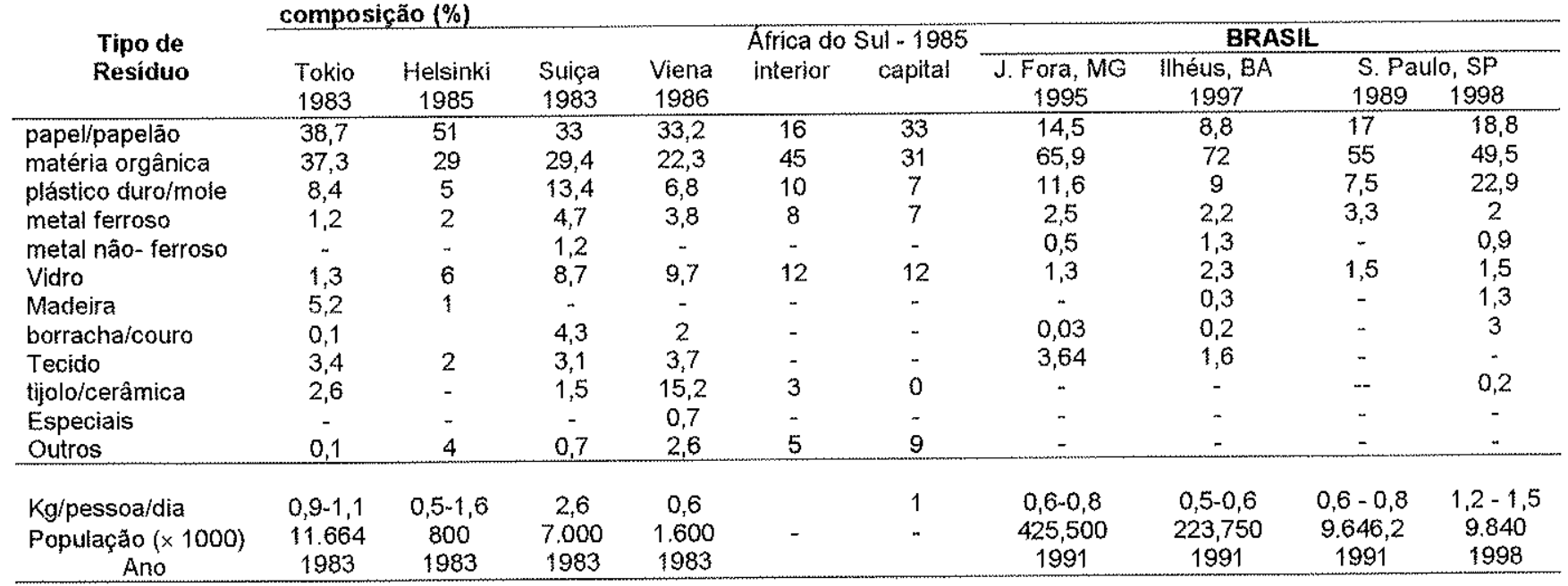

Tabela 2.1 - Classificação dos residuos urbanos gerados em diferentes cidades do mundo (Carra e Cossu 1990, DEMLURB/ Equipe Umah, 1995; Conder/Equipe Umah, 1997; Orth e Motta, 1998 e Calderoni, 1999).

Diante da diversidade composicional dos residuos urbanos, 0 Department of the Environment (1986) agrupa os principais componentes encontrados em quatro classes:

1. elementos maiores e íns - cálcio, ferro, magnésio, ferro, sódio, amônia, carbonatos, sulfato e cioro;

2. componentes orgânicos e espécies orgânicas individuais - os fenóis.

3. componentes microbiológicos

4. metais pesados - manganês, niquel, cádmio, chumbo, cobre, estanho e zinco.

Entre os componentes tóxicos presentes nos residuos municipais destacam-se os metais pesados e os microbiológicos.

Metal pesado é um termo coletivo para um grupo de metais e metalóides que apresenta uma densidade atômica maior que $6 \mathrm{~g} / \mathrm{cm}^{3}$. Atualmente é utilizado amplamente para designar alguns elementos $(\mathrm{Cd}, \mathrm{Cr}, \mathrm{Cu}, \mathrm{Hg}, \mathrm{Ni}, \mathrm{Pb}$ e $\mathrm{Zn}$ ) que estão associados aos problemas de poluição e toxicidade (Alloway 1997). Teoricamente estes elementos pertencem aos metais traços, no entanto, esta nomenclatura é pouco utilizada quando se refere a poluição ambiental.

Os metais pesados são utilizados amplamente nas indústrias eletrônicas, maquinários e artefatos utilizados na vida cotidiana. Sua ocorrência nos resíduos está correlacionada às principais fontes como baterias (inclusive de telefones celulares), pilhas e equipamentos eletrônicos em geral $(\mathrm{Pb}, \mathrm{Sb}, \mathrm{Zn}, \mathrm{Cd}, \mathrm{Ni}, \mathrm{Hg}$ ); pigmentos e tintas ( $\mathrm{Pb}, \mathrm{Cr}, \mathrm{As}, \mathrm{Sb}, \mathrm{Se}, \mathrm{Mo}, \mathrm{Cd}, \mathrm{Ba}, \mathrm{Zn}, \mathrm{Co}, \mathrm{l}$ e Ti); papel $(\mathrm{Pb}, \mathrm{Cd}, \mathrm{Zn}, \mathrm{Cr}, \mathrm{Ba})$, e remédios ( $\mathrm{As}, \mathrm{Bi}, \mathrm{Sb}, \mathrm{Se}, \mathrm{Ba}, \mathrm{Ta}, \mathrm{Li}, \mathrm{Pt}$ ).

Os componentes microbiológicos são representados por vírus, bactérias, protozoários e metazoários originados dos resíduos de origem domiciliar, como animais domésticos mortos, restos 
de alimentos e utensílios diversos contaminados por pacientes portadores de doenças infectocontagiosas (fraldas descartáveis, papel higiênico, absorventes higiênicos, curativos, agulhas e seringas). A sobrevida de microorganismos no ambiente de aterros varia entre 15 a 180 dias no caso de bactérias, e até cerca de 7 anos para metazoários, como o Ascaris lumbricóides, segundo Rocha e Neder (1997).

A evolução do volume de resíduos urbanos gerados no Município de São Paulo, conforme observado no histograma da Figura 2.1 e na Tabela 2.2, apresenta dois patamares distintos. $\mathrm{O}$ primeiro corresponde ao período de 1978 a 1988 e o segundo de 1988 a 1998.

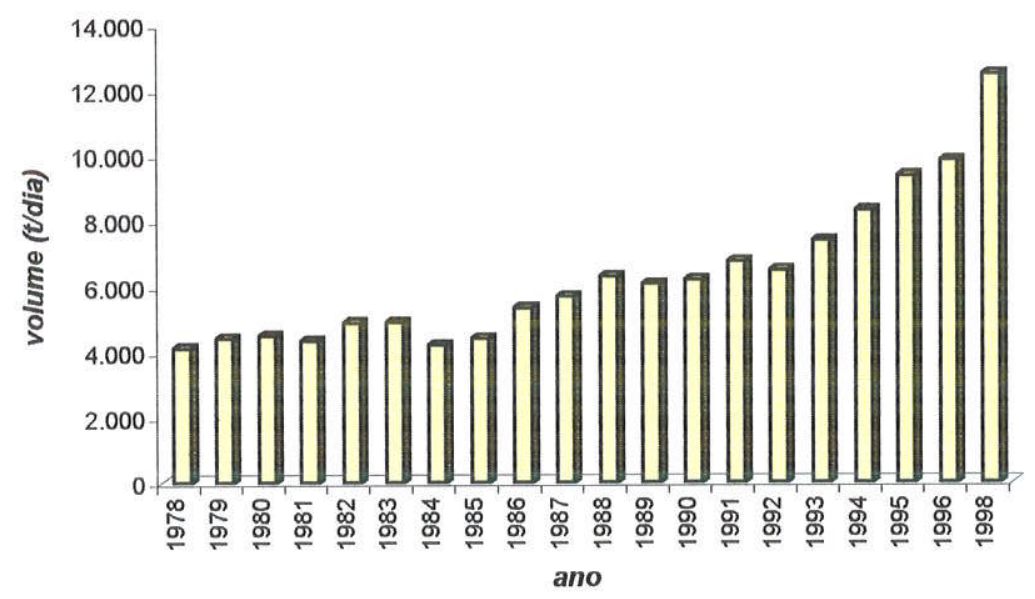

Figura 2.1 - Evolução do volume de resíduos urbanos coletados no Município de São Paulo (1978 - 1998).

\begin{tabular}{cc|cc}
\hline ano & $\begin{array}{c}\text { volume (t/ano) } \\
\text { milhões }\end{array}$ & ano & $\begin{array}{c}\text { volume (t/ano) } \\
\text { milhões }\end{array}$ \\
\hline 1978 & 1.500 & 1989 & 2.212 \\
1979 & 1.608 & 1990 & 2.258 \\
1980 & 1.638 & 1991 & 2.465 \\
1981 & 1.579 & 1992 & 2.368 \\
1982 & 1.779 & 1993 & 2.701 \\
1983 & 1.782 & 1994 & 3.033 \\
1984 & 1.530 & 1995 & 3.424 \\
1985 & 1.604 & 1996 & 3.600 \\
1986 & 1.948 & 1997 & - \\
1987 & 2.072 & 1998 & 4.500 \\
1988 & 2.297 & & \\
\hline
\end{tabular}

Tabela 2.2 - Evolução do volume de resíduos urbanos coletados no Município de São Paulo (1978 a 1998). Extraído de Calderoni (1999) e Orth e Motta (1998). 
O acréscimo do volume no período de 1978 a 1988 foi dado pelo aumento populacional verificado no período, e pelo início do incremento da utilização de embalagens descartáveis, principalmente de plástico.

O aumento no período de 1988 a 1998 foi marcado pelo intenso consumo de produtos de embalagens descartáveis plásticas, cartonadas (tipo Tetra Pack) e latas de alumínio (que começaram a ser produzidas no Brasil a partir de 1989).

Quanto à composição dos resíduos sólidos do Município de São Paulo, durante o período de 1927 - 1998, observam-se alterações importantes na proporção entre a matéria orgânica, plásticos e metal não ferroso (alumínio). Os histogramas das figuras 2.2 e 2.3 e as tabelas permitem visualizar estas diferenças.

A matéria orgânica, apesar de diminuir sua concentração no decorrer do período, ainda detém a maior fração dos resíduos gerados na cidade.

O plástico sofreu o maior acréscimo dentre os constituintes dos resíduos, ocasionado pela entrada de embalagens descartáveis, principalmente de refrigerantes.

Observa-se também um aumento relativo de metal não ferroso. Sua concentração provavelmente é subestimada, uma vez que a contagem foi realizada após a coleta domiciliar, e portanto, parte destes materiais certamente não chegam ao aterro devido ao seu valor comercial de reciclagem.

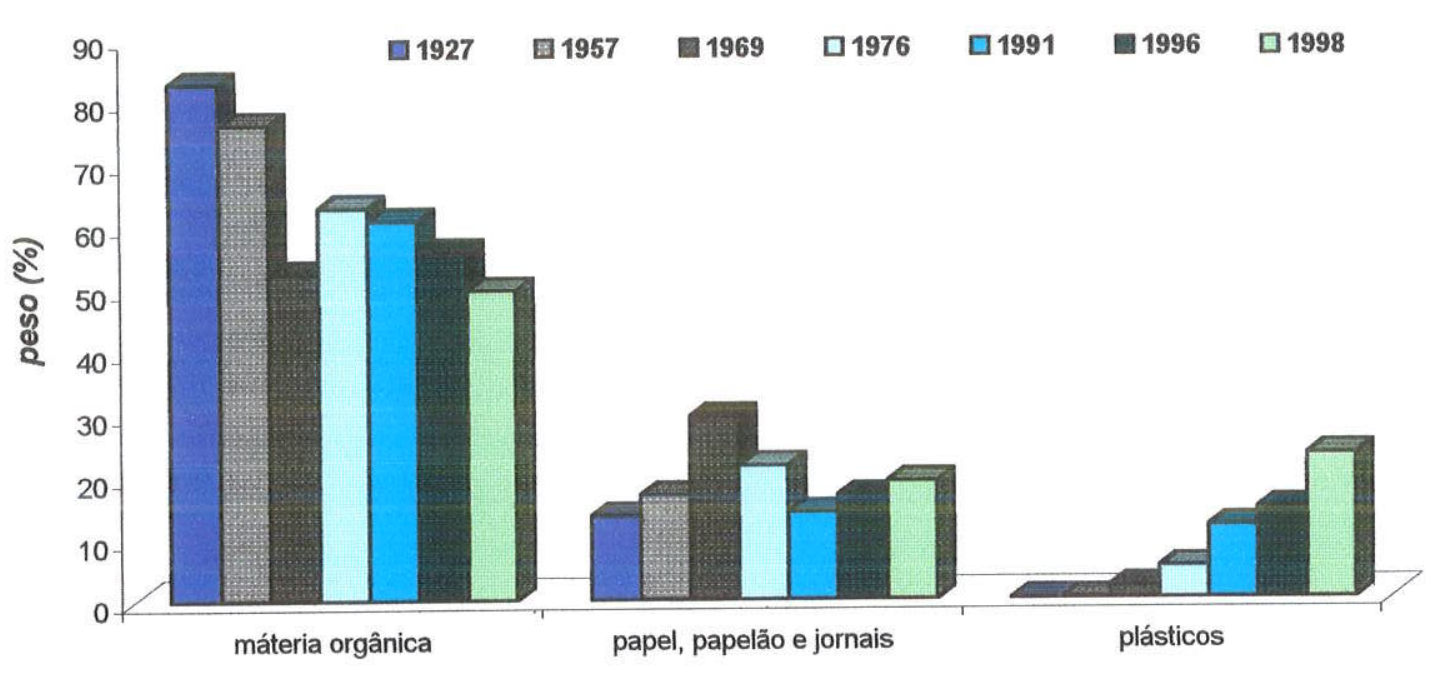

Figura 2.2 - Evolução dos componentes principais dos resíduos urbanos coletados no Município de São Paulo no período de 1927 a 1998. 


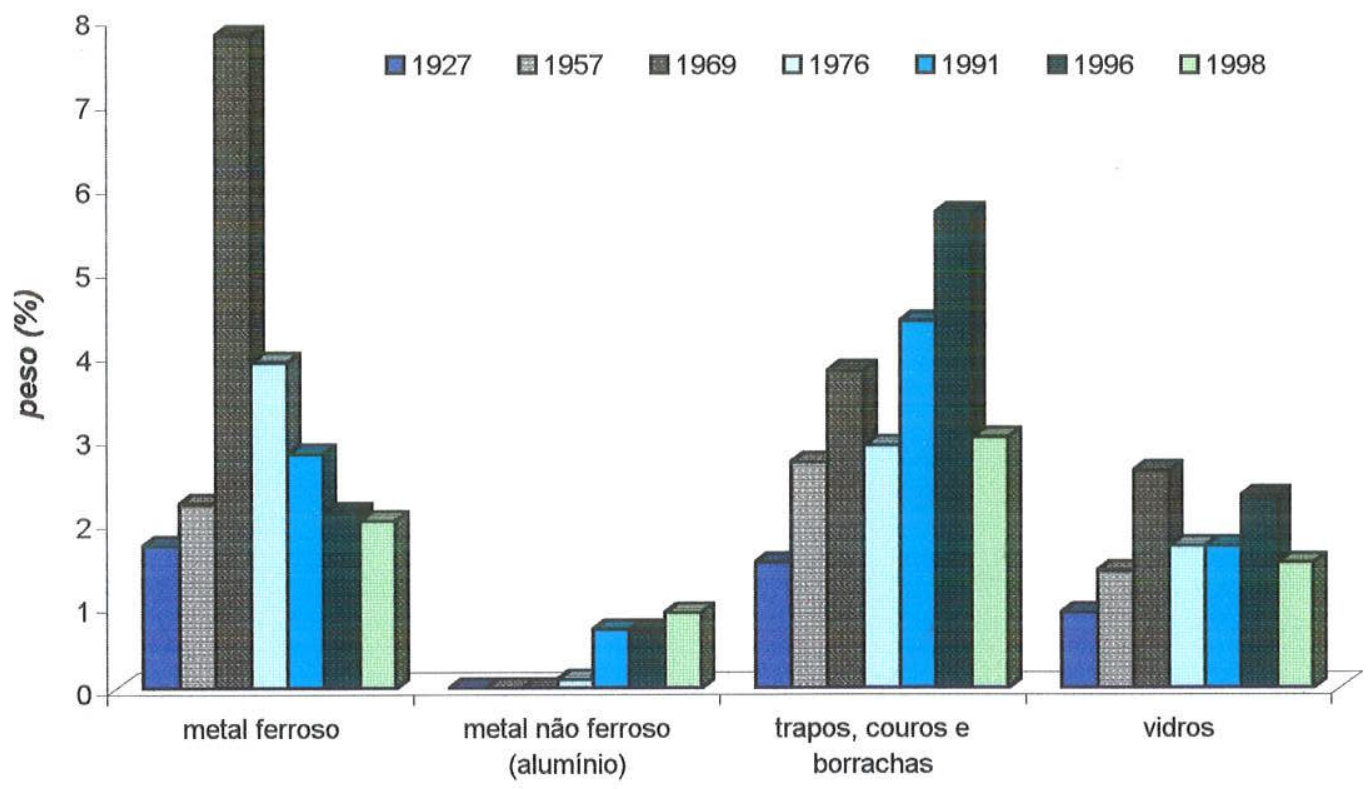

Figura 2.3 - Evolução dos componentes secundários dos resíduos urbanos coletados no Município de São Paulo no período de 1927 a 1998.

\begin{tabular}{|c|c|c|c|c|c|c|c|}
\hline \multirow{2}{*}{ Componente } & 1927 & 1957 & 1969 & 1976 & 1991 & 1996 & 1998 \\
\hline & \multicolumn{7}{|c|}{ porcentagem média em peso (\%) } \\
\hline matéria orqânica & 82.5 & 76 & 52.2 & 62.7 & 60.6 & 55.7 & 49.5 \\
\hline papel, papelão e jornais & 13,4 & 16,7 & 29,2 & 21,4 & 13,9 & 16,6 & 18,8 \\
\hline Plásticos & $\mathrm{nc}$ & $\mathrm{nc}$ & 1,9 & 5 & 11,5 & 14,3 & 22,9 \\
\hline metal ferroso & 1,7 & 2,2 & 7,8 & 3,9 & 2,8 & 2,1 & 2 \\
\hline metal não ferroso (alumínio) & nc & $\mathrm{nc}$ & nc & 0,1 & 0,7 & 0,7 & 0,9 \\
\hline trapos, couros e borrachas & 1,5 & 2,7 & 3,8 & 2,9 & 4,4 & 5,7 & 3 \\
\hline Vidros & 0,9 & 1,4 & 2,6 & 1,7 & 1,7 & 2,3 & 1,5 \\
\hline terras e pedras & nc & $\mathrm{nc}$ & nc & 0,7 & 0,8 & $\mathrm{nc}$ & 0,2 \\
\hline Madeira & $\mathrm{nc}$ & nc & 2,4 & 1,6 & 0,7 & $\mathrm{nc}$ & 1,3 \\
\hline Diversos & nc & 0.1 & nc & nc & 1.7 & 2.6 & nc \\
\hline
\end{tabular}

Tabela 2.3 . Evolução da variação dos componentes presentes nos resíduos urbanos coletados no Município de São Paulo (1927 - 1998). Extraído de Orth e Motta (1998).

\subsubsection{Processo de decomposição}

O processo de decomposição dos resíduos é discutido por diversos autores (Qasim, 1965; Qasim e Buchinal, 1970; Brunner e Keller, 1972; Stanforth et al., 1979; Pfeffer, 1986 e Tchobanoglous et al., 1993).

Stanforth et al. (1979) subdividem o processo em três fases: fase aeróbia, fase anaeróbia e degradação anaeróbia, identificadas pelo comportamento do $\mathrm{pH}$, oxigênio, dióxido de carbono, ácidos voláteis (metano e ácido acético), sais dissolvidos e potencial de óxido-redução, conforme representado nos diagramas da figura 2.4 . 
De acordo com a figura 2.4, o início da decomposição corresponde a fase aeróbia. Esta fase, de menor duração, ocorre no início da percolação da água nos resíduos, apresentando poucos sólidos dissolvidos (baixa concentração de sais), indicada pela baixa condutividade. Iniciase também, a degradação da matéria orgânica, que libera $\mathrm{CO}_{2}$ (aumento da quantidade de $\mathrm{CO}_{2}$ e amônia $\mathrm{NH}_{3}$ ) e ácidos orgânicos (ácido butírico, fórmico, acético, cítrico, dentre outros), através da "queima" de matéria orgânica (respiração de organismos aeróbios). A reação simplificada (Peavy et al. 1985) da "queima" de matéria orgânica com formação de $\mathrm{CO}_{2}$ e amônia $\left(\mathrm{NH}_{3}\right)$ pode ser representada como segue.

$\mathrm{C}_{\mathrm{a}} \mathrm{H}_{\mathrm{b}} \mathrm{O}_{\mathrm{c}} \mathrm{N}_{\mathrm{d}}+\mathrm{O}_{2} \Rightarrow \mathrm{C}_{\mathrm{w}} \mathrm{H}_{\mathrm{x}} \mathrm{O}_{\mathrm{y}} \mathrm{N}_{\mathrm{z}}+\mathrm{CO}_{2}+\mathrm{H}_{2} \mathrm{O}+\mathrm{NH}_{3}$

A reação ocorre porque os resíduos urbanos apresentam alta taxa de DBO, isto é, necessitam de altas quantidades de oxigênio para decompor, principalmente a matéria orgânica. Este aumento de $\mathrm{CO}_{2}$ causa uma diminuição do $\mathrm{pH}$, através de formação de ácido carbônico $\left(\mathrm{H}_{2} \mathrm{O}+\right.$ $\left.\mathrm{CO}_{2} \rightleftharpoons \mathrm{H}_{2} \mathrm{CO}_{3}\right)$ e outros ácidos. $\mathrm{O} \mathrm{pH}$ da solução, inicialmente alcalino $(\mathrm{pH}=8)$ vai se tomando gradativamente ácido $(\mathrm{pH}<7)$.

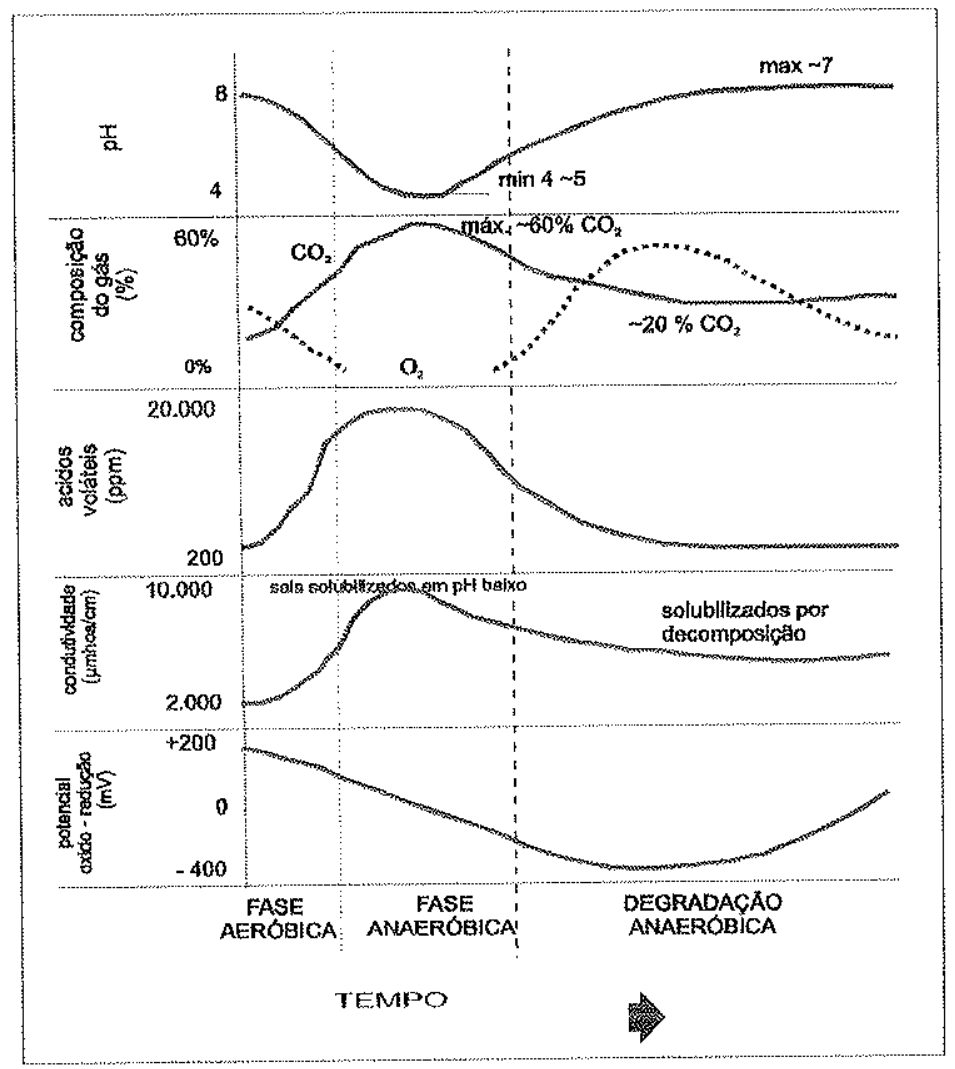

Figura 2.4 - Comportamento de alguns parâmetros físico-químicos durante o processo de decomposição de residuos municipais.

Adaptado de Stanforth et al. (1979). 
Com a evolução do processo de degradação da matéria orgânica, ocorre um excesso de $\mathrm{CO}_{2}$ e deficiência em oxigênio na "atmostera" dos resíduos, o que acaba ocasionando a "intoxicação" dos organismos aeróbios. Inicia-se, portanto, uma predominância de decomposição através de microorganismos anaeróbios. São produzidos ácidos - graxos voláteis (principalmente o ácido acético e o dióxido de carbono), que contribuem na redução ainda maior do $\mathrm{pH}$ (4-5). O baixo pH contribui na solubilização dos componentes inorgânicos, que associados aos ácidos voláteis, aumentam o potencial iônico do percolado. O potencial de redução, nesta fase, torna-se extremamente elevado. A Demanda Bioquímica de Oxigênio/DBO, permanece alta.

A degradação anaeróbia é marcada pela elevação do $\mathrm{pH}$ e aumento brusco da população de bactérias produtoras de $\mathrm{CH}_{4}$ (gás metano). O início desta fase é dada quando a bactéria builds sp começa a se desenvolver, pois necessita ambiente com pH neutro (entre 6,6 a 7,3) (Gaudy \& Gaudy, 1988). Quando o pH encontra-se próximo a neutro, parte dos elementos inorgânicos são solubilizados e o processo de decomposição continua.

De forma mais simplificada, o Department of the Environment (1986) descreve três estágios de degradação dos resíduos:

- o primeiro domina quando a degradação ainda ocorre através do ataque de organismos aeróbios presentes nos resíduos e do oxigênio da atmosfera, que acabam formando componentes orgânicos, dióxido de carbono e água.

- o segundo atua quando o oxigênio é substituido totalmente pelo dióxido de carbono. Os organismos aeróbicos não poderão mais se desenvolver nesta fase pela falta de oxigênio e são extintos. Em substituição, formam-se outros organismos que não dependem exclusivamente de oxigênio, mas que apresentam grande função na decomposição.

- o último ocorre quando as espécies de organismos formadores de metano se multiplicam, decompondo-se em ácido orgânico, para formar gás metano e outros produtos.

A lixiviação dos produtos da degradação da matéria orgânica e inorgânica que constituem os resíduos dão origem ao chorume, principal agente poluidor do solo, das águas superficiais e subterrâneas.

\subsubsection{Chorume}

O Chorume ou Sumeiro é definido pela NBR 8419/1992 como o líquido produzido pela decomposição de substâncias contidas nos resíduos sólidos, que tem como características a cor escura, o mau cheiro e a elevada DBO (Demanda Bioquímica de Oxigênio).

Referências internacionais referem-se ao chorume como leachate, definido como um líquido produzido pela decomposição da matéria orgânica, que pode percolar através de um aterro ou uma pilha de compostagem. Acumula bactérias e outras substâncias perigosas que estão em 
suspensão ou dissolvidas na massa de resíduos, podendo contaminar as águas superficiais e subterrâneas (IETC, 1996).

A composição do chorume varia principalmente em função da composição dos resíduos. Como exemplo, a tabela 2.4 mostra a composição de chorumes de diversas localidades.

\begin{tabular}{|c|c|c|c|c|c|}
\hline Parâmetros & $\begin{array}{c}\text { São João } \\
\text { (São Paulo) }\end{array}$ & $\begin{array}{l}\text { V.Albertina } \\
\text { (São Paulo) }\end{array}$ & $\begin{array}{l}\text { SantoAndré } \\
\text { (Säo Paulo) }\end{array}$ & Inglaterra & $\begin{array}{l}\text { Estados } \\
\text { Unidos }\end{array}$ \\
\hline Cor (MgPr/L) & $9.740,63$ & $-m$ & - & - & - \\
\hline Condutividade $\mu \mathrm{S} / \mathrm{cm}$ & 17.602 & - & - & - & - \\
\hline $\mathrm{PH}$ & 7,83 & 8,2 & 7,9 & 7,0 & - \\
\hline Temperatura ${ }^{\circ} \mathrm{C}$ & 33,8 & - & 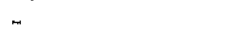 & - & - \\
\hline Turbidez & $1.918,75$ & - & - & - & - \\
\hline Arsênio & $\mathrm{Nd}$ & - & - & - & 0,042 \\
\hline Bário & 0,28 & - & - & - & 0,85 \\
\hline Boro & 6,58 & r & - & - & $\ddot{-}$ \\
\hline Cádmio & 0,03 & nd & - & 0,01 & 0,022 \\
\hline Cálcio & 1.115 & - & - & 700 & - \\
\hline Chumbo & 0,2 & nd & 0,40 & 0,08 & 0,162 \\
\hline Cianeto & nd & $\sim$ & - & - & - \\
\hline Cromo & 0,52 & 0,55 & 0,33 & 0,09 & 0,18 \\
\hline Estanho & 2,27 & - & - & - & - \\
\hline Fluoreto & 1,29 & - & - & - & - \\
\hline Fosfato total & 14,4 & 15 & 21,5 & - & - \\
\hline Fósforo & 15,4 & - & - & - & - \\
\hline Mercúrio & 4,5 & $\sim$ & - & - & 0,002 \\
\hline Níquel & 0,41 & 0,27 & 0,88 & 0,03 & 0,326 \\
\hline Potássio & 1.775 & - & - & 320 & - \\
\hline Prata & 0.04 & -. & - & - & 0,021 \\
\hline Selênio & 0,26 & - & - & - & 0,012 \\
\hline Benzeno & - & - & - & - & 221 \\
\hline Etil benzeno & - & - & - & - & 274 \\
\hline Fenóis Mg/L & 1,9 & 1,4 & 2,28 & - & 2,46 \\
\hline Tolueno & 7,0 & - & - & - & 1,02 \\
\hline Tricloroetileno & & - & + & - & - \\
\hline Xilenos & 2,2 & - & $\cdots$ & - & - \\
\hline Aluminio & 1,6 & - & 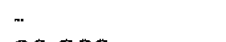 & - & - \\
\hline Cloreto & 2.110 & - & 30.200 & 2.777 & - \\
\hline Cloreto metila & 0,1 & - & - & "' & ." \\
\hline Cloreto de vinila & 20,0 & - & - & - & - \\
\hline Cobre & 0,05 & - & - & 0,03 & 0,17 \\
\hline DBO & 8.375 & 1.510 & 8.160 & 4.286 & - \\
\hline DQO & $13.141,4$ & 3.400 & 13.500 & 6.050 & - \\
\hline Dureza total & $2.133,3$ & - & - & - & - \\
\hline Ferro soluvel & 9,01 & - & -. & 38 & - \\
\hline Ferro total & 140,2 & 48,9 & 254 & - & 221 \\
\hline Magnésio & $340^{\circ}$ & - & - & 215 & - \\
\hline Manganês soluvel & 0,77 & - & - & 13,5 & 9,59 \\
\hline Nitrogenio Kjeldahl & $19.741,3$ & 1.400 & 2.400 & - & - \\
\hline Nitrogenio nitrato & nd & nd & - & 0,77 & 1,88 \\
\hline Nitrogenio nitrito & nd & 0,22 & - & 0,63 & - \\
\hline Oleos e graxas & 53,8 & 71 & 151 & - & - \\
\hline Sódio & $2.108,33$ & - & $-\cdot$ & 1.590 & - \\
\hline Sól. Sediment. & $2.599,4$ & - & - & - & - \\
\hline Sól. Totais dissolvidos & $18.638,5$ & - & - & - & - \\
\hline Sulfato & 19,1 & 8 & 168 & 218 & - \\
\hline Sulfeto & 7,7 & 2,9 & $\mathrm{Nd}$ & - & - \\
\hline $\begin{array}{l}\text { Zinco } \\
\text { MICROBIOLOGICOS }\end{array}$ & 1,06 & 1,3 & 1,5 & 0,20 & 8,32 \\
\hline Coliformes fecais & 670 & 50 & 79.000 & - & - \\
\hline Coliformes totais & 195 & 74.000 & 460.000 & - & - \\
\hline Ct. Pd. Bt. Heter. & 10.500 & - & - & - & - \\
\hline Pseudomonas. Aeroginosa & 7,0 & - & - & $\sim$ & - \\
\hline
\end{tabular}

Tabela 2.4 - Exemplos da composição física-química-bacteriológica de alguns chorumes provenientes de resíduos sólidos urbanos. Adaptado de Robison e Maris (1979), Qasim e Chiang (1994), Tressolti e Consoni (1998), Enterpa (1999). 
O tempo necessário para a degradação dos resíduos é muito variável e depende principalmente da composição destes e do balanço hídrico do aterro. Em regiões áridas, por exemplo, o processo de decomposição é lento, podendo manter os resíduos inalterados por décadas (Qasim e Chiang, 1994).

O balanço hídrico de um aterro é controlado pela taxa de precipitação da região, escoamento superficial, evaporação, transpiração, temperatura, e taxa infiltração no aterro. A taxa de infiltração depende dos principais fatores: 1) duração e intensidade da precipitação; 2) coeficiente de evapotranspiração; 3) coeficiente de escoamento superficial; 4) permeabilidade da cobertura do aterro; 5) grau de compactação dos resíduos; e 6) declividade do terreno. (Leckie et al., 1979).

A Figura 2.5 mostra os diversos mecanismos de escoamento, infiltração e percolação das águas superficiais através da massa de resíduos, com conseqüente produção de chorume e seu comportamento com o solo e as águas subterrâneas.

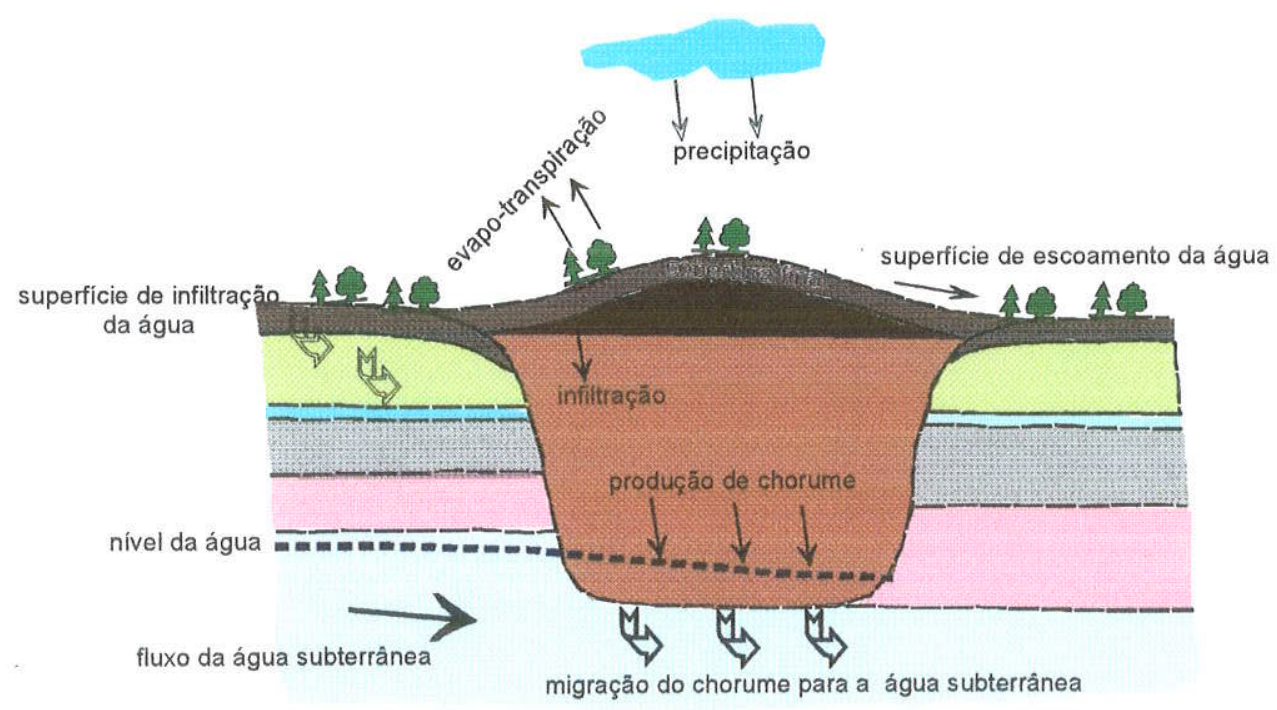

Figura 2.5 - Caminhos de escoamento, infiltração e percolação de águas superficiais no aterro de resíduos (Adaptado de Leckie, et al.,1979)

Os componentes químicos e biológicos presentes no chorume de resíduos domésticos são bastante diversificados, e variam principalmente em função da natureza dos resíduos e do estágio de decomposição da porção biodegradada (Alloway, 1997). 
Brown et. al. (1991) investigou a origem dos elementos tóxicos no chorume de alguns aterros sanitários americanos. Em cada amostra foram realizados três testes para avaliar a toxicidade da biomassa. O resultado das análises químicas mostrou que alguns elementos encontrados no chorume são tóxicos e podem causar câncer, distúrbios genéticos, esterilidade, abortos, distúrbios cardíacos e outros distúrbios crônicos.

A ocorrência destes componentes de potencial cancerigeno levou o autor acima a concluir que o chorume de aterros sanitários municipais é tão tóxico quanto o chorume gerado na disposição conjunta de resíduos domiciliares e perigosos.

Dentre a ocorrência de componentes tóxicos destacam-se os metais pesados. Diferenciamse amplamente dos demais elementos presentes no chorume principalmente devido as suas particularidades químicas e de suas principais fontes.

Os metais pesados, ao contrário de outros contaminantes, como por exemplo os organohalóides", podem ocorrer naturalmente nos solos e nas águas subterrâneas, produto de alteração de rochas e minerais. Portanto, a ocorrência destes metais nos solos e nas águas subterrâneas deve ser comparada com a concentração original da região (background).

O principal componente do chorume é representado pela matéria orgânica biodegradada. Esta matéria ao atingir os corpos de água pode provocar a diminuição do teor de oxigênio dissolvido (OD), decorrente do aumento da demanda bioquímica de oxigênio (DBO). Nos chorumes de aterros sanitários, a DBO pode atingir mais de $60.000 \mathrm{mg} / \mathrm{L}$ (300 vezes maior, que o esgoto sanitário que é da ordem de $200 \mathrm{mg} / \mathrm{L}$ ), provocando impactos adversos na fauna e flora aquática (Tressolti e Consoni, 1998).

Com base no estudo de 30 aterros sanitários nos Estados Unidos, Chian e DeWalle (1976, 1977 a e 1977b) mostraram como a composição química orgânica e inorgânica do chorume produzido por aterros varia ao longo de 16 anos (Tabela 2.5). Identificaram uma grande redução da concentração de sais dissolvidos e matéria orgânica com o avanço da idade do aterro, como conseqüência da lixiviação dos residuos e conseqüente empobrecimento dos residuos nestes elementos, o que leva a uma estabilização química dos aterros com a idade.

\subsubsection{Migração dos contaminantes e atenuação do seu impacto ambiental}

Com a crescente preocupação em proteger os recursos hídricos subterrâneos, o conceito de que os solos, de modo geral, possuem uma capacidade natural em atenuar os contaminantes provenientes da disposição de resíduos foi abandonado, pois sabe-se atualmente, que somente alguns tipos de solos tem a capacidade de reter ou filtrar os contaminantes, impedindo sua progressão em direção a zona saturada. 


\begin{tabular}{|c|c|c|c|}
\hline \multirow[b]{2}{*}{ parâmetros } & \multicolumn{3}{|c|}{ idade do aterro } \\
\hline & 1 ano & 5 anos & 16 anos \\
\hline DBO (demanda bioquímica de oxigênio) & $7.500 * 28.000$ & 4.000 & 80 \\
\hline DQO (demanda química de oxigênjo) & $10.000-40.000$ & 8.000 & 400 \\
\hline Total de sólidos dissolvidos & $10.000-14.000$ & 6794 & 1200 \\
\hline $\mathrm{PH}$ & $5,2-6,4$ & 6,3 & - \\
\hline Condutividade específica & $600-9.000$ & - & - \\
\hline Alcalinidade $\left(\mathrm{CaCO}_{3}\right)$ & $800-4.000$ & 5.810 & 2.250 \\
\hline Dureza $\left(\mathrm{CaCO}_{3}\right)$ & $3.500-5.000$ & 2.200 & 540 \\
\hline Amônia $\left(\mathrm{NH}_{4}\right)$ & $56-482$ & - & + \\
\hline Nitzrato & $0,2-0,8$ & 0,5 & 1,6 \\
\hline Sulfato & $400-650$ & 2 & 2 \\
\hline Cálcio & $900-1.700$ & 308 & 109 \\
\hline Cloro & $600-800$ & 1.330 & 70 \\
\hline Sódio & $450-500$ & 810 & 34 \\
\hline Potássio & $295 \cdot 310$ & 610 & 39 \\
\hline Fósforo Total & $25-35$ & 12 & 8 \\
\hline Manganês & $75-325$ & 0,06 & 0,06 \\
\hline Magnésio & $160-250$ & 450 & 90 \\
\hline Ferro & $210-325$ & 6,3 & 0,6 \\
\hline Zinco & $10-30$ & 0,4 & 0,1 \\
\hline Cobre & - & $<0,5$ & $<0,5$ \\
\hline Cádmio & - & $<0,05$ & $<0,05$ \\
\hline Chumbo & - & 0,5 & 1,0 \\
\hline
\end{tabular}

Tabela 2.5- Evolução da composição do chorume em aterros sanitários, segundo Chian e DeValle (1976, 1977a). Todos parâmetros são expressos em mg/L, com exceção da condutividade em $\mu \mathrm{S} / \mathrm{cm}$ e $\mathrm{pH}$ em unidades de $\mathrm{pH}$

De acordo com Bagchi e Bagchi (1990) a capacidade que alguns solos apresentam em reduzir a ação dos contaminantes do chorume ocorre devido aos processos de atenuação. Atenuação foi definida como um conjunto de reações físicas, químicas e/ou biológicas, ou uma transformação que causa o decréscimo temporário ou permanente na concentração de muitos contaminantes presentes nos resíduos, dado um certo intervalo de tempo e distância.

Os solos são formados por um sistema heterogêneo de fases sólidas, líquidas e gasosas em diferentes proporções. São constituídos por componentes químicos inertes, substâncias com diferentes solubilidades, sais solúveis, componentes insolúveis e uma grande variedade de componentes orgânicos e de organismos.

Na zona insaturada, os poros são preenchidos por água e ar, onde a mobilidade dos contaminantes é condicionada pela textura do solo, tamanho e distribuição das partículas, pela concentração de óxidos hidrogenados (ferro, manganês e alumínio), tipo e concentração de matéria orgânica, capacidade de troca cationica e o pelo pH do solo (Qasim e Chiang, 1994).

A atenuação do chorume ocorre basicamente em dois estágios: o primeiro, através da percolação do liquido pela zona insaturada/solo, e o segundo, no fluxo da água subterrânea.

Os processos naturais de atenuação envolvem mecanismos físicos, químicos e biológicos.

Os físicos envolvem principalmente os processos de filtração, difusão molecular, dispersão hidrodinâmica e diluição (Bagchi, 1990). 
O processo de filtração ocorre devido as diferenças de diâmetro entre as partículas em suspensão no chorume e os poros do solo, o que causa a retenção de material em suspensão. Com a crescente retenção de partículas pela porosidade, a permeabilidade do solo tende a diminuir com o tempo, tendendo a reduzir a percolação do chorume. De modo geral, quanto menor a granulometria, maior a capacidade de troca iônica e retenção de particulas, além de menor permeabilidade, o que torna solos argilosos mais apropriados para receber aterros (tabela 2.6).

Os processos de difusão molecular e dispersão hidrodinâmica compreendem dois mecanismos responsáveis pela diluição dos contaminantes nos aqüiferos. A difusão molecular é originada pela diferença da concentração de contaminantes entre ambientes. Quando existe uma região com alta concentração de contaminantes, estes tendem a migrar para uma região de baixa concentração. A dispersão hidrodinâmica ocorre devido a variação da velocidade do fluxo existente entre os poros e descontinuidades que compõe o solo. Bear (1972) apud Baganha (1996) denomina este processo de dispersão mecânica e de difusão molecular. Este processo é responsável pela dispersão do soluto na direção longiłudinal do fluxo (dispersão longitudinal), e na direção perpendicular deste (dispersão transversal). Seu efeito é positivo na medida que atenua a concentração máxima dos contaminantes. Por outro lado, negativa por aumentar a área atingida pelos contaminantes.

\begin{tabular}{|c|c|c|c|c|}
\hline $\begin{array}{l}\text { TIPODE } \\
\text { SOLO }\end{array}$ & $\begin{array}{l}\text { TAMANHO DO GRAO } \\
(\mathrm{mm})\end{array}$ & $\begin{array}{l}\text { PERMEABLIDADE } \\
(\mathrm{cm} / \mathrm{s})\end{array}$ & $\begin{array}{c}\text { CTC } \\
(\mathrm{meg} / 100 \mathrm{~g})\end{array}$ & $\begin{array}{l}\text { CAPACIDADE PARA RECEBER } \\
\text { ATERROS }\end{array}$ \\
\hline Argiloso & $<0,002$ & $10^{-8} \cdot 10^{-6}$ & $>20$ & $\begin{array}{l}\text { alta, a impermeabilização } \\
\text { pode não ser necessária }\end{array}$ \\
\hline Siltoso & $0,002-0.05$ & $10^{-8}-10^{-3}$ & $12-20$ & $\begin{array}{l}\text { razoável, a impermeabilização } \\
\text { pode ser necessária }\end{array}$ \\
\hline Arenoso & $0,05-0,25$ & $10^{-3}-10^{-1}$ & $1 \cdot 10$ & baixa, impermeabilizaçăo é necessária \\
\hline
\end{tabular}

Tabela 2.6 - Relação entre o tamanho das particulas, permeabilidade de solos e respectivas capacidade de proteção das águas subterrâneas, visando a implantação de aterros sanitários. Adaptado de U. S. EPA (1978) e Qasim e Chiang (1994)

O mecanismo de diluição ocorre quando há mistura entre os constituintes do chorume e a água subterrânea. Quanto mais fina a textura do solo, mais lento é o fluxo e consequentemente, menor é a razão de diluição nas águas subterrâneas. Por exemplo, cloreto, nitrato e sulfato somente são atenuados por diluição, pois não são absorvidos pelo solo (Bagchi, 1990, apud Qasim e Chiang, 1994).

Os processos químicos envolvem a precipitação/dissolução, sorção, complexação, troca iônica e reação de oxi-redução.

Precipitação e dissolução são importantes reações químicas que controlam e limitam a concentração dos contaminantes no chorume durante sua percolação no solo. Dependendo do $\mathrm{pH}$ do solo, estes mecanismos são importantes no controle da migração dos metais pesados. 
A sorção envolve a adsorção e a desorção, principais mecanismos para a atenuação dos metais pesados. Dependem do pH do meio, da natureza do solo e dos contaminantes presentes nos resíduos. Adsorção é um processo que ocorre quando as moléculas se aderem nas partículas de argila. É realizada principalmente por argilo-minerais, alumínio hidratado, ferro, óxido de manganês e constituintes orgânicos. O mecanismo de adsorção acarreta no significativo decréscimo do total de sólidos dissolvidos no chorume. Desorção, ocorre ao contrário, quando as moléculas são liberadas pelas partículas.

A complexação ocorre quando os contaminantes dissolvidos associam-se a outros compostos para formar novos produtos, podendo acarretar no aumento da mobilidade dos contaminantes e alterar seu comportamento químico (Robertson, 1982). De acordo com Qasim e Chiang (1994), trata-se de um processo de atenuação desconhecido e de difícil previsão.

O mecanismo de troca iônica ocorre pela tendência que alguns contaminantes, principalmente os constituintes orgânicos, apresentam em aderir às superfícies de alguns minerais. Dentre os minerais presentes nos solos, a argila destaca-se por possuir tamanho reduzido de suas partículas, favorecendo mais superfícies de contato, e consequentemente, maior disponibilidade para trocas de íons. A capacidade de troca depende do tipo e concentração de argila, do conteúdo de elementos orgânicos e das condições de $\mathrm{pH}$ do solo. A troca é favorecida, em solos com presença de orgânicos e $\mathrm{pH}$ alto.

A reação de oxi-redução ocorre com a alteração da estrutura molecular e das propriedades iônicas dos contaminantes, afełando intensamente as solubilidades destes.

O mecanismo de atenuação biológica envolve os processos aeróbicos e anaeróbicos, onde bactérias e outros microorganismos alteram ou decompõem contaminantes orgânicos e inorgânicos através de reações enzimáticas e de respiração.

Na presença de oxigênio (processos aeróbicos), matéria orgânica, amônia, sulfeto, fósforo, ferro e manganés são convertidos para dióxido de carbono, nitrato, sulfato, fosfato e ferro e manganês no estado oxidado, respectivamente.

Em condições anaeróbias, a matéria orgânica é decomposta para produzir ácido orgânico, dióxido de carbono, metano e vários outros componentes orgânicos. Ocorrem também as reações de denitrificação e redução de metais.

A tendência de migração dos contaminantes em aterros sanitários depende essencialmente das características do solo, das características do chorume e das condições ambientais e de operação do aterro.

O impacto dos principais fatores ambientais e seus efeitos sobre vários constituintes químicos em aterros são descritos a seguir. 
- pHe Potencial de Oxi-Redução

O chorume de aterros é geralmente ácido devido a acumulação de ácidos orgânicos durante o ínicio da decomposição dos resíduos. Muitas reações que ocorrem no chorume são governadas pelo potencial de oxi-redução e pH. Dentre estas reações destacam-se a solubilização e precipitação do $\mathrm{Fe}$, Mn e de outros metais; do enxôfre e fósforo, além da conversão de nitrogênio.

Neutralizações podem ocorrer durante a dissolução de carbonato de cálcio e de outros minerais presentes no perfil do solo

\section{- Matéria orgânica}

A migração da matéria orgânica no sistema solo/água é intensamente influenciada pela atividade microbiológica, superfície de sorção e quelação. A decomposição da matéria orgànica no chorume e no solo é um significante mecanismo de atenuação e migração (Chian, 1977).

\section{- Alcalinidade}

A alcalinidade do chorume é decorrente da presença de carbonatos, bicarbonatos, silicatos, boratos, amônia, bases orgânicas e fosfatos ( Lu et al. 1984).

A migração destas substancias no solo é afetada principalmente por dissolução e precipitação de carbonatos de metais.

\section{+ jons maiores}

Os principais ions incidentes no chorume são: $\mathrm{Na}^{+}, \mathrm{K}^{+}, \mathrm{Ca}^{2+}, \mathrm{Mg}^{2+}, \mathrm{Cl}^{-2}$ e $\mathrm{SO}_{4}^{2-} . \mathrm{A}$ atenuação destes ions depende a solubilidade e troca iônica. A diluição nos aquíferos é a principal causa da diminuição da concentração destes ions.

\section{- Nutrientes}

O nitrogênio e o fósforo são macronutrientes. Nitrogênio pode existir na forma de compostos orgânicos, amônia, niturito ou nitrato. A transformaçăo de nitrogênio depende da presença de microorganismos, $\mathrm{pH}$ e potencial de oxi-redução. Os microorganismos desempenham um importante papel nestas conversões e atenuações.

Os demais mecanismos de atenuação de nutrientes são adsorção, troca iônica e complexação. Os nitratos são relativamente móveis e não são retidos no processo de troca iônica.

Os compostos de fósforo, quando presentes na água e solo, sofrem transformações físicas, químicas e microbiológicas. Os mecanismos de atenuação para os compostos de fósforo são dados predominantemente por transformações biológicas, precipitação, complexação, solubilização e sorção. A solubilidade de fosfato depende do pH e da alcalinidade (Keenan et. al. 1983). 
- Metais traços

O comportamento dos metais traços no solo e na água é extremamente complexo. Os principais mecanismos que influenciam a mobilidade dos metais traços são: precipitação e solubilização; sorção; troca iônica; complexação, quelação e diluição. Cada metal reage de forma distinta no solo e na água, onde os principais fatores que influenciam a mobilidade dos metais são pH, potencial de oxi-redução, atividade microbiológica e química do solo.

\section{- Hidrocarbonetos clorados e pesticidas}

Os hidrocarbonetos clorados pesticidas são atenuados principalmente através da sorção. Outros mecanismos são a volatização, degradação microbiológica, hidrólise, oxidação e diluição. 0 incremento da adsorção e da atenuação dos hidrocarbonetos clorados e pesticidas estão relacionados com o acréscimo do conteúdo de argila (Keenan et. al. 1983).

- Vírus

A sobrevivência do vírus no solo depende do $\mathrm{pH}$, da temperatura, do conteúdo da mistura, dos nutrientes e do antagonismo (Keswichk e Gerba, 1980). Os vírus sobrevivem mais tempo no solo do que na superfície, podendo migrar através do solo em grandes distâncias. Os principais fatores que controlam o movimento dos vírus nos solos são a composição do solo, $\mathrm{pH}$, solubilidade de orgânicos e o volume de chorume.

\subsection{Sitios de disposição de resíduos sólidos urbanos}

A nomenclatura utilizada para as diversas formas de disposição de resíduos sólidos urbanos muitas vezes não corresponde às suas verdadeiras classificações. É muito comum a municipalidade se referir aos seus depósitos de resíduos como aterros sanitários, apesar de que, na maioria das vezes, esta designação não condiz com a realidade.

Aterros representam, a nível mundial, a forma mais ứtilizada para disposição de resíduos, conforme é demonstrado pelos dados da tabela 2.7 .

\begin{tabular}{|c|c|c|c|c|}
\hline & aterros ${ }^{*}$ & incineração & reciciagem & compostagem \\
\hline Austria & 65 & 11 & 6 & 18 \\
\hline Canada & 95 & 4 & 1 & - \\
\hline Dinamarca & 31 & 50 & 18 & 1 \\
\hline Finlândia & 95 & 2 & 3 & - \\
\hline França & 45 & 42 & 3 & 10 \\
\hline Itália & 80 & 14 & 3 & 3 \\
\hline Japâo & 20 & 75 & - & 5 \\
\hline Holanda & 45 & 35 & 15 & 5 \\
\hline Polônia & 100 & - & - & - \\
\hline África do Sul & 72 & 21 & 3 & 4 \\
\hline Suécia & 35 & 60 & 5 & - \\
\hline Suíça & 12 & 59 & 22 & 7 \\
\hline Inglaterra & 88 & 11 & 1 & - \\
\hline EǓA & 67 & 16 & 15 & 2 \\
\hline BRASIL & 99 & 0,1 & nd & 0,9 \\
\hline
\end{tabular}

Tabela 2.7 - Destino dos resíduos em diferentes países, expressos em porcentagem do total de residuos produzidos (SMA/SP, 1998; Carra e Cossu, 1990). 
No Brasil, as formas de disposiçäo de resíduos sólidos urbanos são usualmente designadas como lixão ou vazadouro, aterros controlados e aterros sanitários.

Lixão ou vazadouro é a denominação atribuida para a disposição de resíduos de forma descontrolada sobre o substrato rochoso ou solo. O termo vazadouro é mais utilizado no Estado de São Paulo. Não há critérios técnicos para a escolha e operação destas áreas. Os resíduos são lançados diretamente sobre o solo, podendo ocasionar a contaminação do solo, das águas subterrâneas e superficiais através do chorume e dos próprios resíduos. A exposição dos resíduos favorece a ocorrência de moscas, ratos, urubus e baratas. Decorrente do livre acesso, é comum a presença de animais (porcos, galinhas, patos, cabras), crianças e adultos que reaproveitam restos de alimentos para consumo. Geralmente há a coleła espontânea de materiais recicláveis (papelão, aluminio, vidros e metal) para comercialização. A falta de controle favorece o lançamento clandestino de resíduos de saúde e industrial nestas áreas.

De acordo com a NBR 8849/1985, aterro controlado de resíduos sólidos urbanos é a técnica de disposição de resíduos sólidos urbanos no solo, sem causar danos ou riscos à saúde pública e à sua segurança, minimizando os impactos ambientais, método este que utiliza princípios de engenharia para confinar os resíduos sólidos, cobrindo-os com uma camada de material inerte na conclusão de cada jornada de trabalho

Geralmente o que ocorre na prática, é que o aterro controlado não é nada mais do que um lixão "maquiado", pois há cobertura dos resíduos com solo, mas nem sempre com a mesma freqüencia. Apresenta praticamente os mesmos problemas ambientais que os lixões. Não existem barreiras naturais e/ou artificiais para o chorume não atingir as águas superficiais e subterrâneas, $€$ nem estruturas para captação de gás. O controle da entrada de animais, catadores e dos resíduos lançados geralmente é precário.

No caso do Estado de São Paulo, manifestações públicas e a atuação dos órgãos ambientais (no caso, a CETESB e a Secretaria do Meio Ambiente do Estado de Säo Paulo) na fiscalização e conseqüente aplicações de multas punitivas pelo lançamento de resíduos na forma de lixão, fizeram com que este mecanismo fosse implementado como forma de "mascarar" os prejuizos ambientais no ambiente.

A CETESB (1991) denomina aterros sanitários como aqueles que são projetados e implantados especialmente para dispor resíduos sólidos urbanos, enfatizando que não são adequados para receberem todos os tipos de residuos gerados no município.

Atualmente a filosofia dominante em termos de projeto e implantação de aterros é a da adoção de múltiplas barreiras à liberação de poluentes ao meio ambiente, através da associação das barreiras naturalmente disponiveis (hidrogeologia favorável e isolamento com relação à aqüiferos aproveitáveis) e aquelas criadas pelo homem (construção de camadas impermeabilizantes e sistemas de coleta e tratamento de líquidos percolados). 
No Brasil há poucas normas referentes a disposição de resíduos urbanos, sendo que as existentes sâo polêmicas. A NBR $8419 / 1984$ define os mecanismos de disposição na forma de aterro sanitário como a técnica de disposição de resíduos sólidos urbanos no solo, sem causar danos à saúde pública e à sua segurança, minimizando os impactos ambientais, método este que utiliza princípios de engenharia para confinar os resíduos sólidos à menor área possivel e reduzi-los ao menor volume permissivel, cobrindo os com uma camada de terra na conclusão de cada jomada de trabalho, ou a intervalos menores, se necessário. O projeto a ser elaborado para a implantação de um aterro sanitário deve contemplar todas as instalações fundamentais ao bom funcionamento e ao necessário controle sanitário e ambiental durante o período de operação e fechamento do aterro. A NBR 8849/1985 define a disposição em aterros controlados, conforme citado anteriormente.

De acordo com Rohde (1989), a existência desta última norma constitui uma verdadeira "excrescência", uma vez que sobrepõe o fator econômico à ecologia, à técnica e à saúde pública, na medida em que essa norma é aplicada em substituição a Norma NBR 8419 , que fixa condições mínimas exigiveis para a apresentação de projetos de aterros sanitários de resíduos sólidos urbanos.

Nos Estados Unidos, as formas de destinação dos resíduos sólidos urbanos são classificadas em três categorias principais: open dump (depósito aberto), controlled dump, (depósito controlado) e sanitary landfills (aterros sanitários). Estes três tipos de disposição são extremos de um contínuo de transições. Muitas disposições em paises em desenvolvimento apresentam formas de transição entre estes extremos (IETC, 1996). As principais características, vantagens e desvantagens das respectivas categorias são analisadas na tabela 2.8 .

Na Polônia, de acordo com Kempa e Jedrczak (1990), os resíduos municipais são dispostos nas seguintes formas: uncontrolled dumps (depósitos descontrolados), controlled open dumps (depósitos abertos controlados), controlled semi-sanitary landfills (aterros semi-sanitários controlados), e real sanitary landfills (verdadeiros aterros sanitários). Até a útima década, dentre os 9.000 sítios deposicionais de resíduos existentes no país, somente 20 eram aterros sanitários. Os restantes estavam incluidos nos depósitos descontrolados e abertos controlados.

Na Dinamarca, os aterros sanitários recebem, além dos resíduos urbanos, resíduos de origem industrial (com exceção daqueles oriundos de algumas indústrias químicas) e alguns tipos originados a partir de demolições e construção civil (Christensen, 1990).

A legislação francesa regulamentou três tipos de aterros sanitários, em função das características geológicas, hidrogeológicas e do coeficiente de permeabilidade dos terrenos. Foram denominados de aterros Classe 1, Classe 2 e Classe 3 (Barres et. al. , 1990).

Os aterros de Classe 1 são aqueles que oferecem maior proteção das águas subterrâneas. O terreno que sustenta o aterro deve apresentar uma zona não saturada de no mínimo 5 metros de espessura e coeficiente de permeabilidade menor que $10^{-7} \mathrm{~cm} / \mathrm{s}$. Estes aterros são licenciados para receber alguns tipos de resíduos industriais perigosos. 
Os aterros de Classe 2 apresentam um substrato näo saturado, com espessura mínima de 5 metros de material com permeabilidade homogênea menor que $10^{-4} \mathrm{~cm} / \mathrm{s}$. Estes aterros podem receber resíduos urbanos em geral, que incluem: resíduos domiciliares, objetos grandes (móveis), lodo de estações de tratamento, resíduos industriais näo perigosos, resíduos comerciais e inertes.

Os aterros de Classe 3 podem apresentar substrato com permeabilidade alta (coeficiente menor que $10^{-1} \mathrm{~cm} / \mathrm{s}$ ). Recebem somente resíduos inertes como: solos não contaminados, cascalho e resíduos de construção. Nesta classe a água subterrânea é vulnerável a contaminação.

\begin{tabular}{|c|c|c|c|}
\hline FORMA & CARACTERISTICAS & VANTAGENS & DESSVANTAGENS \\
\hline $\begin{array}{l}0 \\
0 \\
\frac{\alpha}{\alpha} \\
m \\
m \\
0 \\
0 \\
0 \\
0 \\
0 \\
0 \\
0\end{array}$ & $\begin{array}{l}\text { não há seleção de sítios } \\
\text { " não há estimativa da capacidade } \\
\text { não há planejamento de disposição } \\
\text { pouca ou inexistente preparação } \\
\text { não há controle de chorume } \\
\text { " não há controle de gás } \\
\text { eventual cobertura dos residuos } \\
\text { não há compactação dos residuos } \\
\text { não há barreiras die isolamento } \\
\text { nâo há registro dos res. dispostos } \\
\text { catadores e comércio de residuos } \\
\text { recicláveis }\end{array}$ & $\begin{array}{l}\text { facilidade de acesso } \\
\text { vida útil estendida } \\
\text { baixo custo inicial } \\
\text { baixo custo inicial } \\
\text { baixo custo inicial } \\
\text { baixo custo inicial } \\
\text { baixo custo inicial e decomposição } \\
\text { aeróbia } \\
\text { idem } \\
\text { baixo custo, e acesso a catadores } \\
\text { custo inicial baixo } \\
\text { recuperação e venda dos residuos } \\
\text { úteis }\end{array}$ & $\begin{array}{l}\text { - contaminação ambiental } \\
\text { uso exagerado/descontrolado } \\
\text { contaminação ambiental } \\
\text { necessita de remediação } \\
\text { contaminaçáo da água } \\
\text { subterrânea e superficial } \\
\text { * risco de explosão } \\
\text { ação de vetores de doenças } \\
\text { redução da vida útil } \\
\text { uso indiscriminado, doenças } \\
\text { não há registro dos residuos } \\
\text { baixa eficiência para } \\
\text { reaproveitamento de recicláveis }\end{array}$ \\
\hline $\begin{array}{l}0 \\
0 \\
0 \\
5 \\
0 \\
0 \\
0 \\
0 \\
0 \\
0 \\
0 \\
0 \\
0 \\
0 \\
0 \\
0 \\
0 \\
0\end{array}$ & 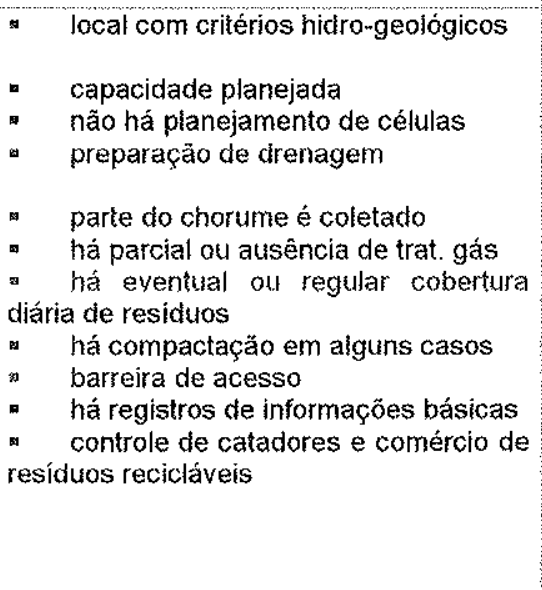 & $\begin{array}{l}\text { * } \quad \text { baixo risco de contaminação } \\
\text { " planejamento por longo tempo } \\
\text { baixo custo inicial } \\
\text { facilidade de escoamento da água } \\
\text { da chuva, reduçāo do risco } \\
\text { moderado custo } \\
\text { custo moderado, redução do custo } \\
\text { custo moderado/redução do risco } \\
\text { vida útil prolongada } \\
\text { controle de acesso e uso da área } \\
\text { informaçóes úteis } \\
\text { há a recuperação de residuos } \\
\text { recicláveis, com baixo risco de saúde } \\
\text { para os catadores }\end{array}$ & 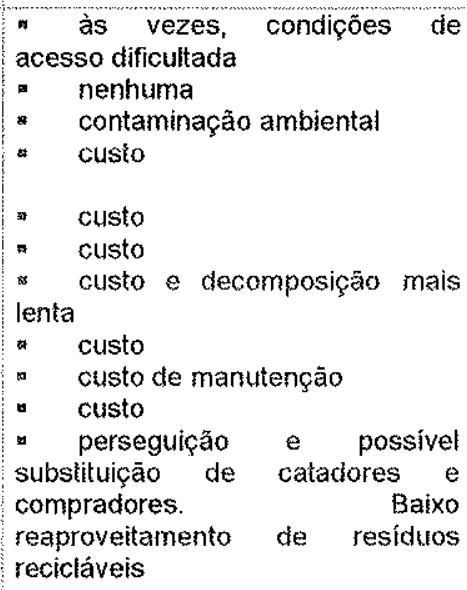 \\
\hline 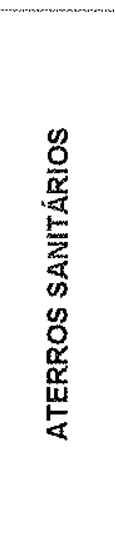 & $\begin{array}{l}\text { seleção de sítios segundo critérios } \\
\text { de riscos ambientais } \\
\text { c capacidade planejada } \\
\text { " desenvolvimento de projeto de } \\
\text { células - disposiçäo } \\
\text { extensiva preparaçäo do sitio } \\
\text { tratamento total do chorume } \\
\text { tratamento total do gás } \\
\text { cobertura diária e final } \\
\text { compactação } \\
\text { barreira/cerca e portaria } \\
\text { resíduos degistro de volume, tipo e fonte de } \\
\text { não há separaçäo de resíduos } \\
\text { recicláveis por catadores }\end{array}$ & $\begin{array}{l}\text { minimizaçäo de riscos ambientaís } \\
\text { permite o planejamento por iongo } \\
\text { tempo } \\
\text { minimização de riscos ambientais } \\
\text { risco reduzido no sítio } \\
\text { risco reduzido de poluçäo } \\
\text { risco reduzido de acidente } \\
\text { controle de vetores e estética } \\
\text { extensão da vida útil } \\
\text { acesso restritivo/controle resíduos } \\
\text { informaçöes valiosas } \\
\text { não há riscos de saúde para } \\
\text { catadores }\end{array}$ & $\begin{array}{l}\text { acesso, processo demorado } \\
\text { de escolha de sítios } \\
\text { nenhuma } \\
\text { custo } \\
\text { custo, tempo de preparaçäo } \\
\text { custo } \\
\text { custo } \\
\text { custo, decomposiçäo lenta } \\
\text { custo } \\
\text { custo de manutençäo } \\
\text { custo de equipamento } \\
\text { baixo reaproveitamento de } \\
\text { residuos recicláveis quando não há } \\
\text { programa de reciclagem. }\end{array}$ \\
\hline
\end{tabular}

Tabela 2.8 - Depósitos abertos, depósitos controlados e aterros sanitários. Características básicas, vantagens e desvantagens. Adaptado de IETC (1996). 
A África do Sul adota um método semelhante ao francês, e classifica os terrenos para o recebimento de resíduos de acordo com a espessura e o indice de permeabilidade dos seus substratos. Deste modo, os terrenos são classificados em três classes (Verrier, 1990):

Classe 1 - apresentam substrato com permeabilidade menor que $10^{-\hat{\sigma}} \mathrm{cm} / \mathrm{s}$. Devido a sua baixa permeabilidade, estes terrenos são considerados como perfeita barreira para a contenção de contaminantes. Estes sitios, recebem resíduos perigosos e róxicos e são operados pelo setor privado. No país, é restrita a ocorrência destes sítios.

Classe $\mid 1$ - apresentam substrato com até 2 metros de profundidade com índice de permeabilidade in situ que varia entre $10^{-6}<\mathrm{k}<10^{-3} \mathrm{~cm} / \mathrm{s}$. A maioria destes sítios são operados pelo setor público para a disposição de resíduos urbanos.

Classe III - apresentam substrato de permeabilidade maior que $10^{-3} \mathrm{~cm} / \mathrm{s}$. Estes sítios não servem para disposição de nenhum tipo de resíduo.

Na ltália, as categorias de aterros sanitários são classificadas em:

$1^{\text {a }}$ Classe: aqueles que recebem exclusivamente resíduos municipais (incluem os domiciliares, de construção civil, de áreas públicas e arruamentos).

$2^{a}$ Classe são subdivididos em: Tipo $A$ (recebem residuos inertes); tipo $B$ e $C$ (recebem resíduos especiais e alguns tipos de resíduos tóxicos e perigosos).

$3^{a}$ Classe recebem resíduos altamente perigosos e tóxicos. São considerados depósitos temporários, onde os resíduos são estocados em containers, podendo ser posteriormente depositados com maior segurança (Cossu e Urbini, 1990).

\subsection{Critérios relativos ao meio físico para a seleção de áreas para aterros sanitărios}

Mundialmente, até o final da década de 60 , os sítios destinados ao recebimento de resíduos eram implantados e operados sem a preocupação com a contaminação do solo e dos recursos hídricos. A justificativa desta atitude era que os contaminantes seriam atenuados naturalmente pelo solo, e consequentemente, não atingiriam as águas subterrâneas. Estudos tem provado que mesmo pequenos aterros podem contaminar a água subterrânea, principalmente aqueles que não sofreram pesquisa de seleção de áreas e não apresentaram projetos específicos (Bagchi, 1990 e Kelly, 1976).

Ferguson (1990) descreve o método de seleção de sítios utilizado no Canadá à partir da década de 50, do século passado. No início da década de 50 , os aterros eram implantados em áreas acessiveis e disponiveis, freqüentemente de pequenas dimensões e muitas vezes inseridas em terrenos baixos. Nesta ocasião, a implantação de dispositivos para a drenagem e as condições de permeabilidade dos terrenos nem sempre eram as maiores preocupações. A partir da década de 60 , a implantação de aterros em terrenos secos, topograficamente elevados, com áreas maiores e impermeabilização de base natural ou artificial tornou-se popular. 
No Brasil, ainda é comum a disposição de resíduos em áreas de fácil acesso, de pequenas dimensôes e em terrenos baixos. Como exemplos, na Região Metropolitana de São Paulo, o lixão de Carapicuíba - inserido em antigas cavas de exploração de areia na planície de inundação do Rio Tietê, o lixão de Juquitiba - nas margens do Rio São Lourenço e da BR 116 e o antigo lixão de Mogi das Cruzes (hoje denominado de aterro controlado) - instalado sobre antigos portos de areia na margem do Rio Tietê.

É praticamente de consenso geral, entre as referências consultadas, que a seleção de sítios é considerada uma das mais difíceis e controvertida etapa a ser cumprida no processo de implantação de um aterro sanitário, principalmente pelo fato de ser uma fonte potencial de poluição das águas superficiais e subterrâneas, e de alto índice de rejeição pela população vizinha.

Na Dinamarca, por exemplo, os aterros sanitários são considerados fontes potenciais importantes de poluição das águas subterrâneas. Os principais problemas em relação a implantação de novos aterros sanitários relacionam-se às suas localizações perante o risco de poluição das águas, e da forte opinião pública contrária a implantação de aterros circunvizinhos as suas residências. No meio físico, os principais critérios utilizados para a seleção de sítios referemse as condições de exploração da água subterrânea, a classificação das águas superficiais e a disponibilidade de argila e areia (áreas de empréstimo) para material de cobertura dos resíduos. $E$ outros critérios referentes aos aspectos sócio - econômicos. A avaliação final dos sitios é realizada através da identificação e valorização específica de três a quatro sítios, antes da decisão final de escolha (Christensen, 1990).

Davis e Cornwell (1991) apresentam os aspectos principais que devem ser avaliados no processo de escolha de sítios para aterros sanitários. Com relação ao meio físico destacam-se: estudos hidrogeológicos, avaliação do material de cobertura, avaliação de áreas sujeitas a inundações e ocorrência de áreas úmidas. Recomenda que os sítios não estejam inseridos em distâncias inferiores de: a) 30 metros de rios b) 160 metros de poços de abastecimento de água subterrânea c) 65 metros de residencias, escolas e parques e d) 3.000 metros das pistas de aeroportos.

Outros aspectos devem ser considerados, destacando-se: oposição pública, proximidade com rodovias, limite de velocidade e de carga admissivel das vias de acesso, capacidade das pontes de acesso, condições de tráfego, ocorrência de congestionamentos, distância e tempo médio de percurso, zoneamento urbano, ocorrência de patrimônios históricos e de espécies em extinção.

Qasim e Chiang (1994) enfatizam que devem ser evitadas as áreas que necessitam de soluções de engenharia complexas, as áreas de recarga de aqüiferos, as zonas pantanosas/encharcadas e as planícies de inundação. Recomendam a implantação em terrenos com baixa permeabilidade, baixas condições de umidade e que os poços de captação de água subterrânea estejam inseridos a montante do aterro. 
O'Leary et.al.(1986), Pfeffer (1992) e Tchobanoglous et.al.(1993) correlacionam diversos fatores a serem considerados na escolha de sítios para aterros sanitários e seus respectivo grau de limitação, apresentados na tabela 2.9.

\begin{tabular}{|c|c|c|c|c|}
\hline \multirow{2}{*}{\multicolumn{2}{|c|}{ fatores }} & \multicolumn{3}{|c|}{ grau de limitação } \\
\hline & & máximo & moderado & mínimo \\
\hline \multicolumn{2}{|c|}{ Declividade do terreno } & $>15 \%$ & $3-15 \%$ & $>3 \%$ \\
\hline \multicolumn{2}{|c|}{ Substrato } & areia limpa/grauvacas & areia/lama & silte \\
\hline \multicolumn{2}{|c|}{ Profundidade da rocha } & argila $>3$ metros & $3-7,6$ metros & $>7,6$ metros \\
\hline \multicolumn{2}{|c|}{ Tipo de rocha/substrato } & rocha fraturada & arenito & - \\
\hline \multicolumn{2}{|c|}{ Profundidade do N.A. } & $<3$ metros & 3 a 6 metros & $>7,6$ metros \\
\hline \multirow{4}{*}{ 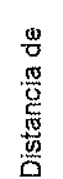 } & Poço de água & $<91$ metros & 91 a 305 metros & $>305$ metros \\
\hline & Planicie de inundação & $<91$ metros & 91 a 305 metros & > 305 metros \\
\hline & Rios/lagos & $<305$ metros & - & $>305$ metros \\
\hline & Parques & $<305$ metros & - & $>305$ metros \\
\hline
\end{tabular}

obs: valores originais em pés foram convertidos para metros segundo a relaçāo $M=f t \times 0,3048$

Tabela 2.9 - Principais fatores do meio físico e seus respectivos graus de limitação a serem considerados na escolha de sítios para aterros sanitários. Adaptado de O'Leary et. al. (1986), Pfeffer (1992) e Tchobanoglous et. al. (1993).

Segundo Lechner (1990), a seleção de sítios para aterros sanitários na Áustria deve seguir os seguintes requisitos do meio físico:

- formulação dos requisitos hidrogeológicos é de extrema importância pois não há garantia de que a impermeabilização de aterros resista a $100 \%$ por tempo indefinido;

- as condições do solo e da água subterrânea devem ser investigadas até profundidades que possam potencialmente ser afetadas pela infiltração de chorume;

- de modo geral, aterros devem ser localizados em áreas onde a água subterrânea não é disponivel, não é apropriada para consumo humano ou ocorre com volume limitado a uso local;

- deve ser localizada acima da altura máxima do nível da água;

- a área do aterro e seus arredores imediatos devem ter condições hidrogeológicas constantes;

- o sítio do aterro deve incluir uma área de proteção com $300 \mathrm{~m}$ de dístancia contornando o aterro;

- aterros sanitários não devem ser localizados em áreas cársticas nem em terrenos com importantes reservas de água subterrânea no presente ou reservas potenciais do futuro;

- aterros não devem ser localizados em áreas de preservação ambiental. 
De acordo com Cossu e Urbini (1990), as recomendações geológicas e hidrogeológicas para o planejamento da seleção de áreas e implantação de aterros sanitários na ltália devem compreender:

- Estudo geológico geral

- compilação da cartografia geológica em escala 1:25.000 do local do aterro e de uma área circunvizinha com um raio de no mínimo $5 \mathrm{~km}$.

- preparação de seções geológicas de detalhe para visualizar as tendências de fluxo da água subterrânea, assim como, demarcar setores impermeáveis dentro da área acima cartografada.

- Estudo hidrogeológico geral

- no mapa supracitado , localizar todos pontos de capatação de água superficial e realizar o mapeamento piezométrico da água subterrânea da área do aterro.

- Estudo geológico de detalhe

- mapeamento geológico 1:5.000 da área delimitada para o aterro.

- amostragem mecânica do solo até interceptar o nivel da água.

+ Estudo hidrogeológico de detalhe

- instalação de piezômetros para registrar a variação do nível da água e prever se este poderá atingir a base do aterro.

- levantamento de dados históricos sobre alturas máximas da superfície piezométrica e investigações para calcular os limites máximos de enchentes na área do aterro e entorno.

- levantamento da qualidade da água subterrânea a ser obtido durante o estudo piezométrico.

- ensaios de permeabilidade do terreno em campo e em laboratório.

- confecção de mapa de permeabilidade da área escolhida para o futuro aterro.

Na ltália é incentivada a locação de sittios em áreas degradadas por mineração, por proporcionar a recuperação ambiental destas áreas através da disposição de resíduos.

No Brasil, trabalhos mais recentes vem sendo publicados enfatizando os critérios para seleção de áreas para implantação de aterros sanitários, sendo que alguns também citam a análise de sítios em áreas degradadas pela mineração.

De acordo com o Manual de Gerenciamento Integrado - Resíduos Municipal (IPT/CEMPRE, 1995), os estudos de viabilização de áreas para instalação de aterros sanitários devem compreender uma seqüencia de atividades para a identificação e a análise de suas aptidões. Uma área com características físicas adequadas significa menores riscos ao meio 
ambiente e a saúde pública. Assim, os trabalhos de viabilização exigem a compatibilização de vários fatores, buscando-se o equilibrio entre os aspectos sociais, as alterações do meio ambiente e os custos inerentes do empreendimento. A ponderação dos diversos fatores considerados, deve resultar na classificação de áreas selecionadas, segundo as seguintes categorias (Tabela 2.10): 1) Recomendada: quando pode ser utilizada nas presentes condições, atendendo às normas vigentes com baixo investimento; 2) Recomendada com Restrição: quando pode ser utilizada necessitando medidas complementares de médio investimento; 3) Não Recomendada: quando não se recomenda sua utilização em função da necessidade de medidas complementares de alto investimento.

Segundo Tressolti e Consoni (1998), estes critérios devem indicar uma primeira orientação, devendo ser considerados os parâmetros geológicos e hidrogeológicos de cada local e sua influência na migração de contaminantes.

\begin{tabular}{|c|c|c|c|}
\hline \multirow{2}{*}{$\begin{array}{c}\text { TTENS } \\
\text { ANALISADOS }\end{array}$} & \multicolumn{3}{|c|}{ CLASSIFICACGÁO DE LOCAIS } \\
\hline & RECOMENDADO & $\begin{array}{l}\text { RECOMENDADO } \\
\text { COM RESTRIÇŌES }\end{array}$ & NÄO RECOMENDADO \\
\hline Vida útjl & $>10$ anos & \multicolumn{2}{|c|}{10 anos, a critério do órgāo ambiental } \\
\hline Distância do gerador & $10<$ distância $<20 \mathrm{~km}$ & \multicolumn{2}{|c|}{$>20 \mathrm{~km}$} \\
\hline Distância de núcleo urbano & $>500$ metros & \multicolumn{2}{|c|}{$<500$ metros } \\
\hline Densidade populacional & baixa & média & alta \\
\hline Zoneamento ambiental & \multicolumn{2}{|c|}{ sem restriçoes no zoneamento urbano } & unidades de conservação \\
\hline Zoneamento urbano & vetor crescimento mínimo & vetor intermediário & vetor máximo \\
\hline Uso e ocupaçäo das terras & \multicolumn{2}{|c|}{ áreas devolutas ou pouco utilizadas } & ocupaçâo intensa \\
\hline Valor da Terra & baixo & médio & alto \\
\hline Acéftação popular & boa & razoável & inaceitável \\
\hline Distância aos cursos de água & $>200$ metros & \multicolumn{2}{|c|}{$<200$ metros - com aprovação do órgão ambiental responsável } \\
\hline Declividade & $1-20 \%$ & \multicolumn{2}{|c|}{$<1 \%$ ou $>20 \%$} \\
\hline $\begin{array}{l}\text { Profundidade do nivet de } \\
\text { água }\end{array}$ & 3 metros & 1,5 metros & $<1,5$ metros \\
\hline $\begin{array}{l}\text { Condutividade hidráulica do } \\
\text { subsolo }\end{array}$ & $10^{-8} \mathrm{~cm} / \mathrm{s}$ - desejável & $5,0 \times 10^{-5} \mathrm{~cm} / \mathrm{s}$ & $>5 \times 10^{-5} \mathrm{~cm} / \mathrm{s}$ \\
\hline
\end{tabular}

Tabela 2.10 - Principais critérios para avaliação preliminar de locais para disposição de resíduos, segundo IPT/CEMPRE (1995) e Tressolti e Consoni (1998).

A norma ABNT 13.896/1997 (antiga PN: 603.06-006) que trata de critérios para projeto, implantação e operação de aterros não perigosos (considerados de classe II, conforme a NBR 10.004 ), estabelece que o impacto ambiental a ser causado pela instalação do aterro seja minimizado; que a aceitação da instalação pela população seja maximizada; que a área esteja de acordo com o zoneamento da região; e que o sítio possa ser utilizado por um longo período de tempo, necessitando apenas de um mínimo de obras para início da operação. Justifica que para o atendimento das diretrizes acima, diversas considerações técnicas deverão ser abordadas, tais como: 
- Topografia do terreno: classificado como fator determinante para a escolha do método construtivo do aterro. Recomenda-se locais com declividade superior a $1 \%$ e inferior a $30 \%$.

- Geologia e cobertura superficial : refere-se como aspectos importantes na determinação da capacidade de depuração do solo e da velocidade de infiltração dos poluentes. Considera-se desejável a existência, de um depósito natural extenso e homogêneo de materiais com coeficiente de permeabilidade inferior a $10^{-6} \mathrm{~cm} / \mathrm{s}$ e uma zona não saturada com espessura superior a 3,0 metros.

- Recursos hidricos: deve ser avaliada a possivel influência do aterro na qualidade e no uso das águas superficiais e subterrâneas próximas. Recomenda-se que o aterro deve estar localizado a uma distância mínima de 200 metros de qualquer coleção hídrica ou curso de água. A mudança desta distância pode ser permitida pelo orgão estadual de controle da poluição ambiental.

Além dos aspectos físicos, diversos fatores foram levantados para consideração, tais como: condições de acesso, tamanho disponível e vida útil da área, viabilidade econômica do empreendimento e distância mínima de núcleos habitacionais.

No que se refere ao tamanho e vida útil, é recomendada a construção de aterros em áreas que possuam vida útil superior a $10(\mathrm{dez})$ anos.

Quanto a distância de núcleos habitacionais é recomendada que seja superior a 500 metros.

A norma menciona que obrigatoriamente, em qualquer caso de escolha de área, os seguintes critérios devem ser considerados:

- a implantação de aterros não deve ser executada em áreas sujeitas a inundações, em períodos de recorrência de 100 anos;

- a superfície inferior do aterro e o nivel mais alto do lençol freático deve ser constituído por uma camada natural de solo insaturado de 1,50 metros. Ressalta que o nível de água deve ser medido durante a época de maior precipitação pluviométrica da região;

- aterro deve ser executado em áreas onde haja predominância no subsolo de makerial com coeficiente de permeabilidade inferior a $5 \times 10-5 \mathrm{~cm} / \mathrm{s}$. Estipula que a permeabilidade do subsolo pode variar de acordo com o critério adotado pelo OCA. Esta mudança pode vir a ocorrer de acordo com o tipo de resíduo e as condiçōes hidrogeológicas do local. Ressalia que o valor da permeabilidade não pode exceder a $10-4 \mathrm{~cm} / \mathrm{s}$.

Como exemplo de critérios utilizados para avaliar o potencial de áreas para uso como aterros sanitários, cita-se o estudo realizado pela Hicsan/Etep (1994), que correlaciona os principais compartimentos geológicos-geomorfológicos com caracteristicas hidrogeológicas e geotécnicas para avaliar os terrenos da RMSP visando a disposição de resíduos, conforme é sintetizado na tabela 2.11 . 


\begin{tabular}{|c|c|c|c|c|c|}
\hline \multirow{2}{*}{$\begin{array}{l}\text { COMPARTIMENTO } \\
\text { GEOLOGICO E } \\
\text { GEOMORFOLOOGICO }\end{array}$} & \multicolumn{2}{|c|}{ HIDROGEOLOGIA } & \multicolumn{2}{|c|}{ GEOTECNIA } & \multirow{2}{*}{$\begin{array}{l}\text { POTENCIAL } \\
\text { PARA USO } \\
\text { COMO ATERRO } \\
\text { SANITARIO }\end{array}$} \\
\hline & $\begin{array}{c}\text { potencial } \\
\text { hidrogeológico }\end{array}$ & $\begin{array}{l}\text { vulnerabilidade } \\
\text { do aqüifero }\end{array}$ & $\begin{array}{l}\text { capacidade de } \\
\text { suporte do solo }\end{array}$ & $\begin{array}{l}\text { adequabilidade } \\
\text { para material de } \\
\text { empréstimo }\end{array}$ & \\
\hline $\begin{array}{l}\text { Sedimentos aluvionares } \\
\text { quaternários (argilas, arejas, } \\
\text { cascalhos e turfas } \\
\text { PLANICIES ALUVIONARES }\end{array}$ & baixo & muito aita & baixa & inadequado & $\begin{array}{l}\text { muito pouco } \\
\text { favorável }\end{array}$ \\
\hline $\begin{array}{l}\text { Sedimentos terciários da } \\
\text { Formação Sâo Paulo } \\
\text { (arenitos, siltitos e argilitos) } \\
\text { COLINAS E MORROTES }\end{array}$ & muito alto & média & $\begin{array}{c}\text { alta } \\
\text { necessidade } \\
\text { de compactação } \\
\text { do solo superficial }\end{array}$ & adequado & $\begin{array}{l}\text { relativamente } \\
\text { favorável }\end{array}$ \\
\hline $\begin{array}{l}\text { Granitos, migmatitos e } \\
\text { gnaisses. } \\
\text { MORROTES, MORROS e } \\
\text { SERRAS }\end{array}$ & alto & alta & $\begin{array}{l}\text { alta (solo superficial } \\
\text { compactado) } \\
\text { baixa (solo de } \\
\text { alteraçāo) }\end{array}$ & $\begin{array}{l}\text { adequado (solo } \\
\text { superficial) } \\
\text { inadequado (solo } \\
\text { de alteração) }\end{array}$ & pouco favorável \\
\hline $\begin{array}{l}\text { Filitos, xistos, micaxistos. } \\
\text { PREDOMINAM MORROS e } \\
\text { SERRAS }\end{array}$ & baixo & baixa & $\begin{array}{l}\text { alta (solo superficial } \\
\text { compactado), } \\
\text { média (solo de } \\
\text { alteração) }\end{array}$ & adequado & favorável \\
\hline $\begin{array}{l}\text { Anfibolitos } \\
\text { MORROS E SERRAS }\end{array}$ & muito baixo & muito baixo & $\begin{array}{l}\text { alta, quando } \\
\text { compactado. }\end{array}$ & adequado & muito favorável \\
\hline $\begin{array}{l}\text { Calcários e mármores } \\
\text { COLINAS e MORROS }\end{array}$ & médio & muito aita & baixa & inadequado & desfavorável \\
\hline
\end{tabular}

Tabela 2.11 - Potencialidade relativa dos compantimentos na RMSP para disposição final de residuos. Adaptado de Hicsan-Etep (1994) 


\subsection{ESTUDO DE CASOS}

O principal objetivo do estudo de casos é exemplificar e discutir o estabelecimento de critérios físicos adotados no processo de escolha de sítios para a implantação de aterros sanitários.

Foram escolhidos os municípios de Juiz de Fora (Minas Gerais) e Ilhéus (Bahia) pelo fato da autora da presente dissertação ter participado dos trabalhos relativos ao meio físico durante o processo seletivo das áreas para aterro sanitário destes municípios.

Conforme citado anteriormente, o Município de São Paulo foi escolhido por tratar-se de um aterro sanitário que sofreu processo seletivo de áreas.

\subsection{Município de Juiz de Fora}

\subsubsection{Caracterização geral do município de Juiz de Fora/MG}

O município de Juiz de Fora situa-se na porção SSE do Estado de Minas Gerais, próximo a divisa com o Estado do Rio de Janeiro, na região conhecida como Zona da Mata. Abrange uma área de aproximadamente $1.434 \mathrm{~km}^{2}$, limitada pelos municípios de Lima Duarte, Pedro Teixeira, Bias Fortes, Santos Dumont, Ewbank da Câmara, Piau, Bicas, Piqueri, Santana do Deserto, Matias Barbosa, Rio Preto, Belmiro Braga, Coronel Pacheco e Chácara. As principais vias de acesso são as rodovias federais BR - 040 (Rio de Janeiro - Belo Horizonte) e BR - 267 (Juiz de Fora Caxambú) (figura 3.1).

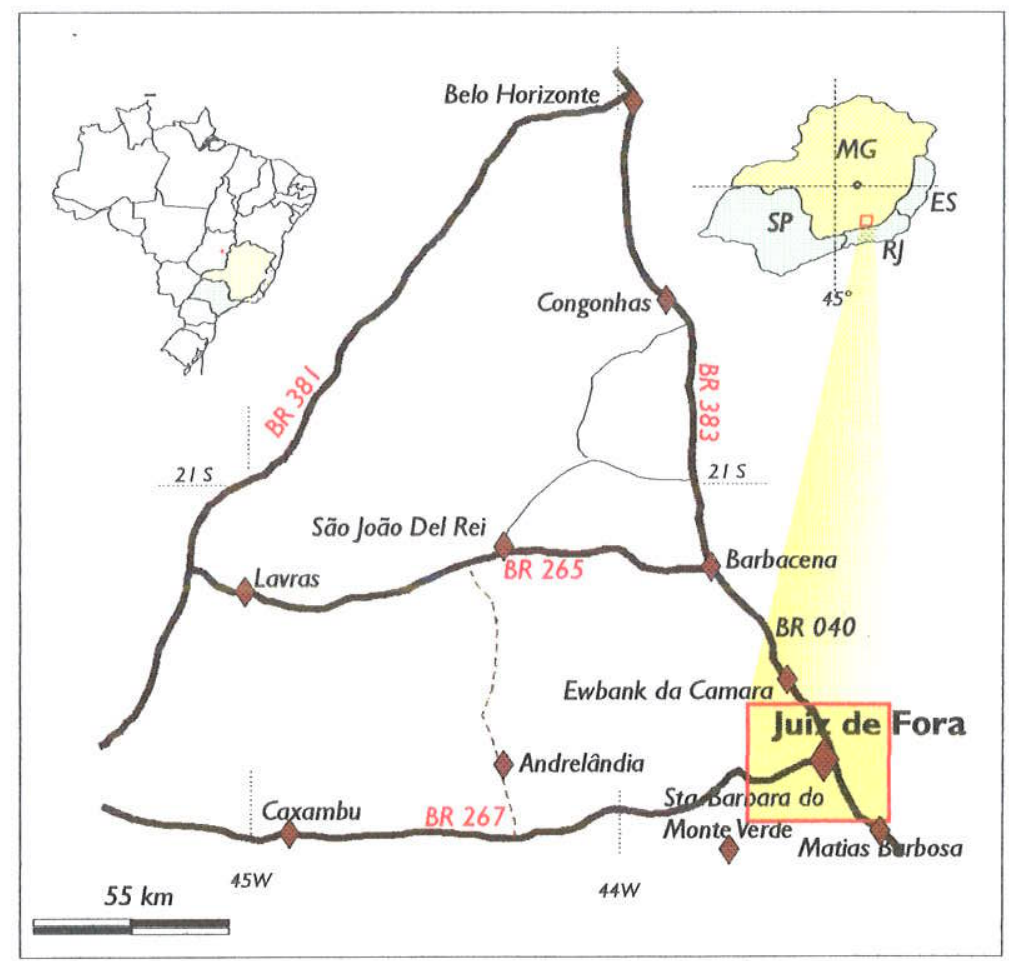

Figura 3.1 - Localização geral do município de Juiz de Fora (MG). 
Nos primórdios de sua origem, a atividade econômica predominante era a produção de café, que depois, foi substituída pelo desenvolvimento da pecuária leiteira e, por conseqüência, da indústria de laticínios. Em tempos mais recentes teve seu parque industrial incrementado, recebendo por isso, o antigo cognome de "Manchester Mineira". Este parque, embora diversificado, tem como setor predominante o têxtil, a indústria mecânica, a indústria automobilística e o beneficiamento de produtos alimentícios (foto 1).

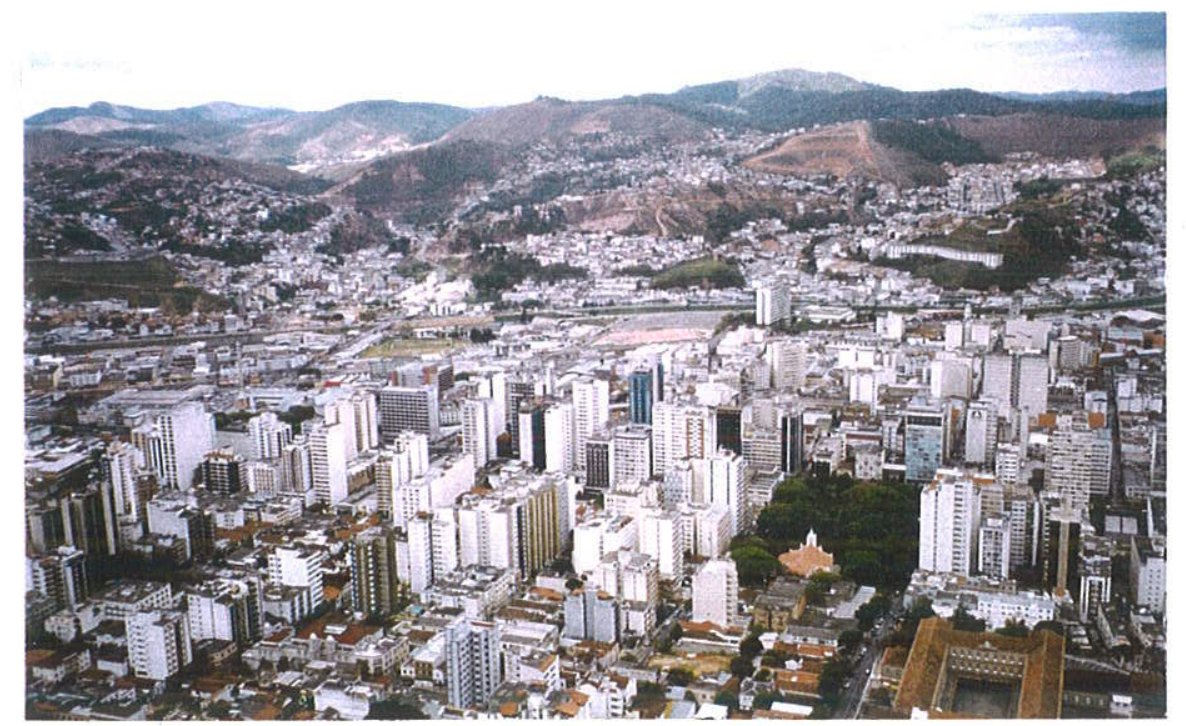

Foto 1 - Vista parcial da mancha urbana do município de Juiz de Fora. Nota-se a região da planície do Rio Paraibuna densamente ocupada. No fundo, ocupação seauindo em direcão ao domínio dos morros e morrotes.

Em 1995, a população urbana era de 424.479 habitantes (http:// www.ibge.gov), que gerava, aproximadamente, 260 toneladas/dia de resíduos urbanos compostos essencialmente por matéria orgânica (66\%), papel/papelão(14,5\%), plástico (11,5\%) e metais (3\%) (Demlurb/Equipe Umah, 1995) - Tabela 2.1 - pag. 7.

\subsubsection{Geologia}

A geologia do município é caracterizada por rochas metassedimentares e ortometamórficas de alto grau e idade proterozóica média. Predominam rochas charnockíticas (para e ortognaisses, milonitos e migmatitos) associadas ao Complexo Juiz de Fora (Oliveira, 1980) no setor oriental. Na porção centro-ocidental do município, predominam rochas do Grupo Andrelândia compostas por xistos, gnaisses e quartzitos (Fonseca, 1979).

O mapeamento geológico mais recente deve-se a Nogueira (1999), realizado na escala de 1:50.000 e integrado em 1:100.000 (Figura 3.2). Este autor apresenta uma compartimentação tectônica e litológica do município, onde o setor noroeste é ocupado pelo Domínio Tectônico Andrelândia (DTA) e o setor sudeste pelo Domínio Tectônico Juiz de Fora (DTJF). O DTA é composto por hornblenda gnaisses migmatíticos, sillimanita-biotita gnaisses com muscovita 
quartzitos e anfibolitos. O DTJF, separado do DTA por uma importante zona de cisalhamento de baixo angulo, é composto por granada-biotita gnaisses, biotita-hornblenda gnaisses com intercalações de quartzitos, calcossilicáticas, anfibolitos, granitóides e charnokitos. Ambos domínios são marcados pelo imbricamento de cunhas tectônicas associadas a falhas de empurrão, onde a estrutura principal é o bandamento gnáissico e a xistosidade.

\subsubsection{Geomorfologia}

O município insere-se na unidade geomorfológica dos Planaltos Cristalinos Rebaixados (DNPM 1976), com altitudes médias entre 800 a 900 metros, e declividade das vertentes bastante variada, em média de 12 a $50 \%$.

O relevo predominante é do tipo "mar-de-morros" ou "meias-laranjas", que é caracterizado por apresentar vertentes convexas e declividades entre 12 a 30\%. Os vales são predominantemente planos e alargados, devido a baixa energia de transporte dos rios, que originam planícies alveolares, pelo acúmulo de dedritos proveniente das vertentes.

As planícies mais desenvolvidas estão inseridas ao longo do Rio do Peixe, Paraibuna e da Represa Dr. João Penido. As áreas com encostas de maiores declividades ocorrem predominantemente a Oeste (Serra da Saudade) e, dispersas, a Sul e Leste do município.

\subsubsection{Cobertura Superficial}

Regionalmente a cobertura superficial apresenta espessura extremamente variada. São comuns a presença de afloramentos rochosos e regolito com até cerca de 50 metros de espessura, com grandes matacões e maciços tipo "pão-de-açúcar", gerados por esfoliação esferoidal (foto 2).

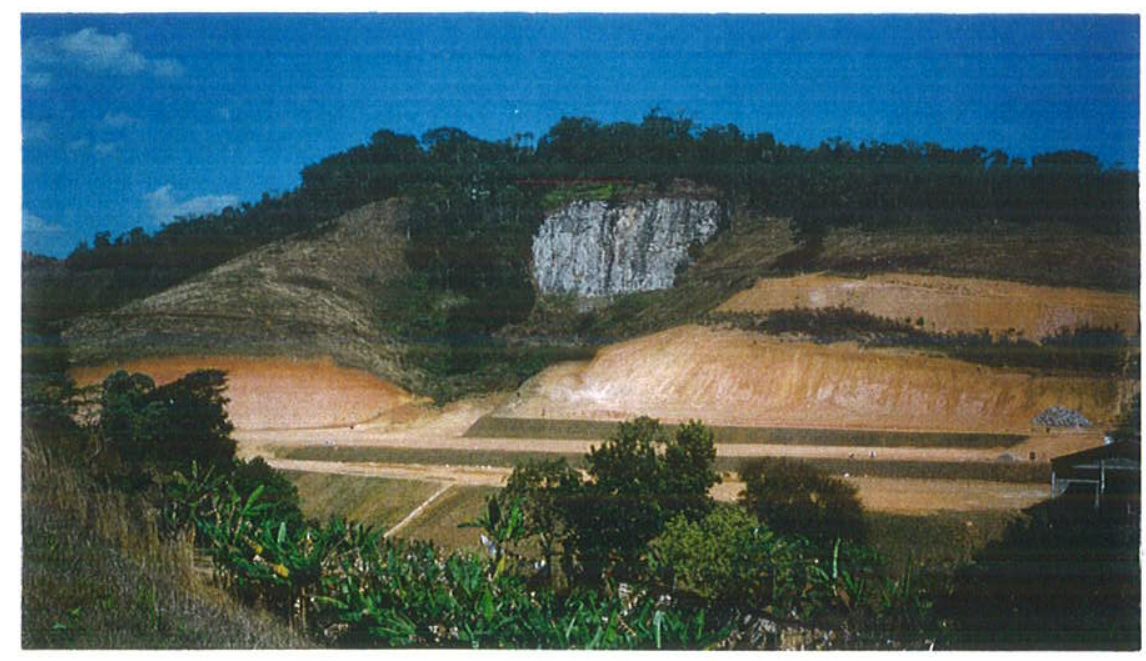

Foto 2 - Corte na rodovia BR 267 próximo a mancha urbana de Juiz de Fora (MG). Relevo de morrotes e morros arredondados com manto intempérico de espessura extremamente variável e arandes matacões e macicos de esfoliacão esferoidal. 


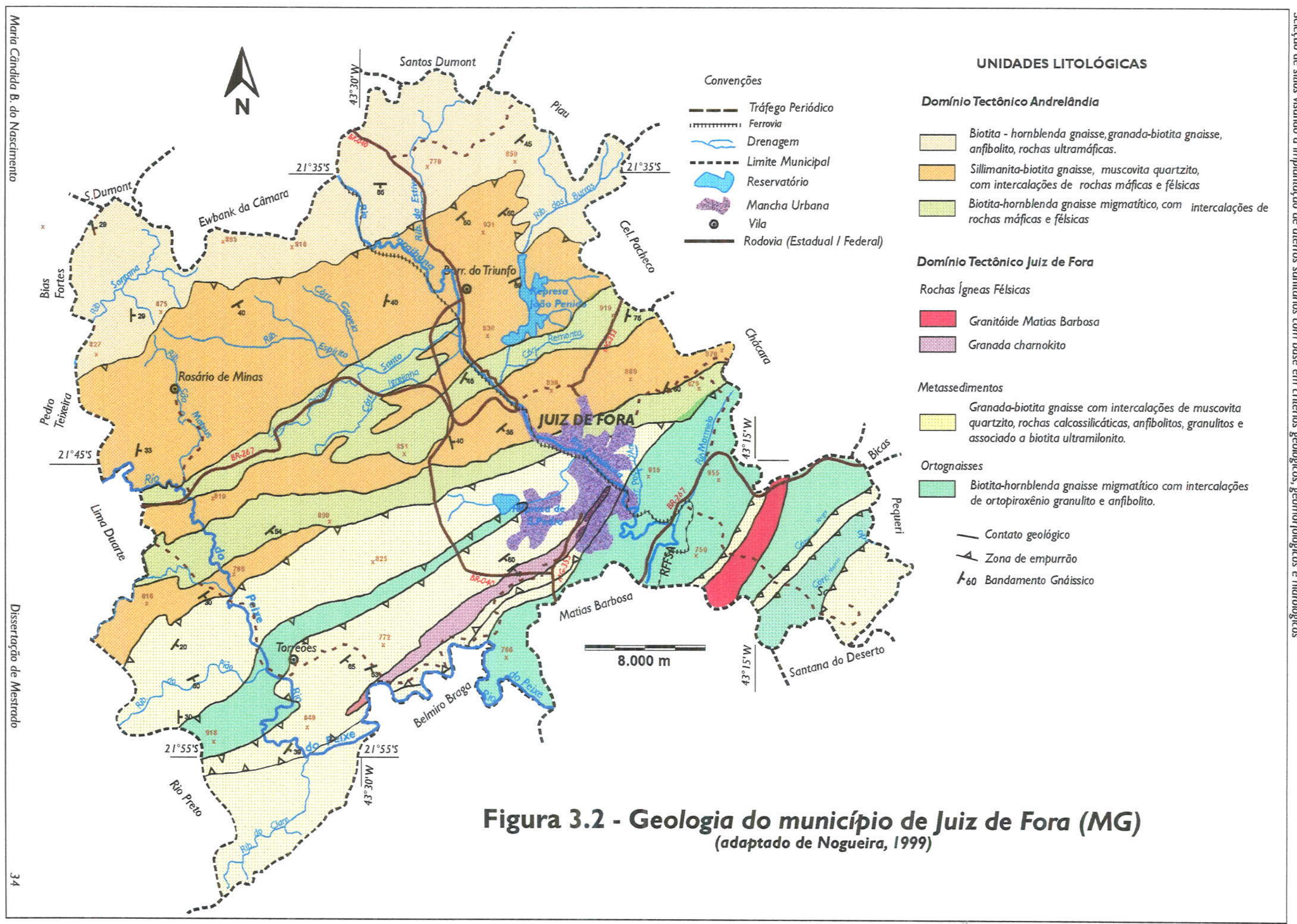


De acordo com Radambrasil (1983), os solos que ocorrem na região são cambissolos distróficos, com associações de solos litólicos distróficos e latossolo vermelho-amarelo distrófico, predominante.

Os cambissolos são pouco profundos, textura média, arenosos e muito susceptível a erosão laminar. A Noroeste do município é comum a presença de Latossolo Vermelho - Amarelo, de textura, areno - argilosa, relativamente menos susceptivel a fenômenos de erosão, e mais susceptivel a escorregamentos do tipo corrida de massa.

\subsubsection{Drenagem superficial}

A rede de drenagem superficial é densa e de padrão predominantemente dendrítico, pertencente à bacia hidrográfica do Paraíba do Sul.

O principal rio em extensão e volume que intercepta o município é o Rio Paraibuna, afluente do Rio Paraíba do Sul. Pertence a classe 1, no trecho de sua nascente até a barragem de Chapéu D' Uvas, de classe 2, no trecho da barragem de Chapéu D' Uvas até a sua foz no Rio Paraíba do Sul. Na bacia hidrográfica deste rio há o Decreto Federal $n^{\circ} 87.561$, de 13/09/82 que dispõe sobre as medidas para sua recuperação e proteção ambiental (Datalegis e Fundação SOS Mata Atlântica, 1996).

Seus principais afluentes na margem direita são o Rio do Peixe e o Córrego São Pedro, na esquerda, o Córrego dos Burros e o Rio Cágado.

\subsubsection{Clima}

De acordo com a classificação de Köppen, o clima predominante na região é do tipo Cwb Mesotérmico Úmido. É caracterizado pela ocorrencia de veröes brandos e invernos secos. A temperatura média na região oscila entre $18-20^{\circ} \mathrm{C}$. O regime pluviométrico é marcado por chuvas de verão e inverno seco. As chuvas predominam no período de outubro a março, com maior índice pluviométrico em dezembro, chegando a exceder $300 \mathrm{~mm}$ (INM, 1995).

\subsubsection{Cobertura Vegetal}

A cobertura vegetal primitiva que caracterizava a região, denominada de Zona da Mata, praticamente não existe mais. Nos trechos serranos há poucos remanescentes de vegetação. 


\subsubsection{Processo de seleção de áreas para o aterro sanitário em Juiz de Fora (MG)}

\subsubsection{Histórico da pesquisa de sítios no município}

Os primeiros estudos para pesquisa de áreas foram iniciados pela Secretaria de Planejamento da Prefeitura Municipal em 1986. Na ocasião, o lixo domiciliar, hospitalar e parcela do lixo industrial era depositado em lixão, inserido no fundo de um pequeno vale de um afluente do Rio Paraibuna, próximo a mancha urbana (porção Noroeste). A ação de catadores, o comprometimento da qualidade das águas, a presença de criações de suínos e aves no local fizeram com que a prefeitura municipal pesquisasse novos sítios para a implantação de um aterro sanitário.

Esta pesquisa resultou na delimitação de nove sítios de interesse, inseridos nas sub-bacias dos córregos Igrejinha, Humaitá e Teixeira Prata. Dentre estes, somente um sítio foi classificado com aptidão boa, denominado de Matias Barbosa. O sítio situa-se a $7 \mathrm{Km}$ a montante da cidade homônima, e foi destinado para receber os resíduos urbanos gerados na época.

Em 1991, após 5 anos da realização do primeiro estudo, as péssimas condições ambientais do sítio Matias Barbosa, cuja disposição continuava sendo na forma de lixão, fez com que a prefeitura municipal novamente retomasse os estudos para a aquisição de um novo sítio.

Este estudo foi iniciado com a análise de um sítio situado no divisor de águas do Córrego Igrejinha e Ribeirão Espirito Santo. As sondagens realizadas mostraram que se tratava de um substrato essencialmente arenoso. A alta permeabilidade do terreno e sua proximidade com as nascentes do Ribeirão Espírito Santo (manancial de abastecimento de água de Benfica) descartaram o sítio como uso para aterros sanitários.

Novas áreas foram pesquisadas em terrenos que não eram drenados pelas bacias hidrográficas que compõem os mananciais abastecedores de água do município (São Pedro, João Penido e Espirito Santo) e nem incidentes em áreas protegidas legalmente (Bacia Hidrográfica do Rio do Peixe e Reservas Biológicas).

Foram selecionados 06 sítios que situavam-se nas proximidades dos bairros Barão do Retiro e lgrejinha para investigações mais detalhadas.

Dentre estes, 2 sítios esłavam inseridos em cavas abandonadas resultantes da extração de caulim e saibro, sendo descartados por apresentarem nivel freático sub - aflorante e baixa capacidade volumétrica.

Três sitios foram descartados por apresentarem terrenos alagadiços no sopé das vertentes, e pela suas proximidades com a BR 267. Apresentavam como condicionantes favoráveis: ausência de matas, proximidade com a Usina de Compostagem, facilidades de acesso, uso rural das terras, distantes de núcleos habitacionais e conformação topográfica.

O útimo, situado no Bairro Igrejinha, a NW da mancha urbana, foi considerado o mais apropriado para a implantação do aterro. Os motivos que levaram a prefeitura a escolher a área 
foram: inserido fora de áreas de mananciais; proximidade com a Usina de Reciclagem, ausência de atividade agro-industrial no local e a proximidade com a zona industrial do município. Com relação ao meio físico, foi recomendada a realização de investigações geológico - geotécnicas para determinar a viabilidade técnica - ambiental do terreno para a implantação e operação do aterro sanitário.

Em 1995, após quatro anos da realização da última pesquisa de sítios, os resíduos continuavam sendo lançados no lixão de Matias Barbosa (foto 3). As péssimas condições sanitárias e ambientais do local, e certamente a pressão popular fizeram com que o poder público municipal contratasse serviços técnicos especializados para a prospecção de sítios para implantar um aterro sanitário no município.

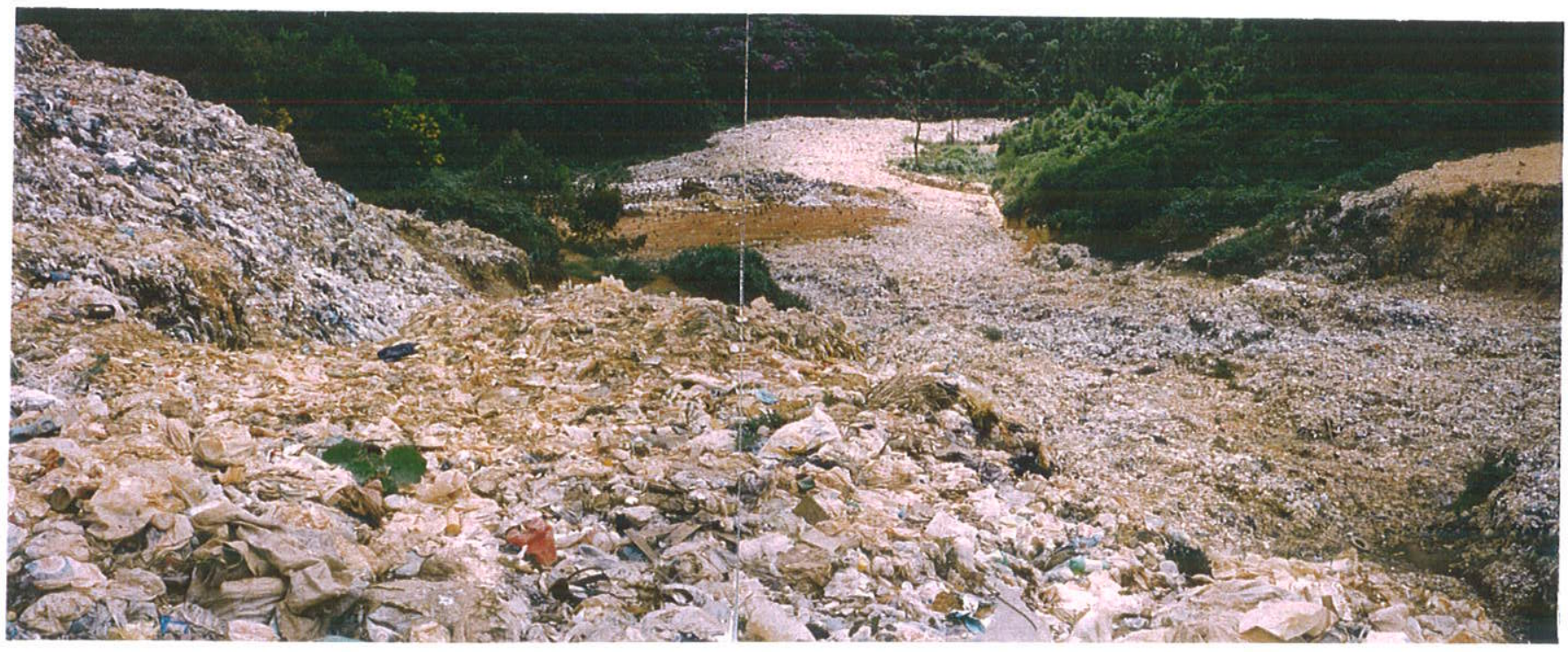

Foto 3 - Vista geral do lixão Matias Barbosa, área de disposição dos resíduos municipais e de saúde gerados por Juiz de Fora. Nota-se a disposição inadequada dos resíduos.

\subsubsection{Método utilizado para a seleção de sítios}

O início do processo de seleção de sítios foi marcado pelo reconhecimento dos diversos fatores ambientais que pudessem apresentar algum tipo de incompatibilidade com 0 aterro sanitário.

Para a realização desta etapa de trabalho foram consultados os acervos existentes junto as entidades municipais e estaduais. Dentre os órgãos visitados destacam-se: o Instituto de Pesquisa e Planejamento da Prefeitura Municipal/IPPLAN, Departamento Municipal de Limpeza Urbana/DEMLURB, Companhia de Esgoto, Saneamento e Meio Ambiente/. CESAMA, Fundação Estadual do Meio Ambiente/FEAM, Empresa de Assistência Técnica e Extensão Rural/ EMATER.

As áreas consideradas incompatíveis perante a implantação e operação do aterro foram: as bacias hidrográficas contribuintes dos atuais e futuros mananciais; as áreas verdes tombadas e 
de interesse municipal, a mancha urbana e de expansão urbana, as captações de água superficiais e subterrâneas, área de proteção militar (Área do Exército) e de cinturão - verde (Figura 3.3).

As bacias hidrográficas contribuintes dos atuais mananciais de abastecimento municipal compreenderam : Represa Dr. João Penido, Represa de São Pedro, da Represa Poço D'Antas e do Ribeirão Espírito Santo). As bacias estratégicas para abastecimento futuro de água : Rio do Peixe e do Ríbeirão do Estiva.

As áreas verdes: Área de Proteção Ambiental da Mata do Krambeck, Reserva Biológica Municipal de Santa Cândida, Parque Municipal da Lajinha, Morro do Imperador, Parque Halfeld, Parque Municipal do Museu Mariano Procópio, Bosque do Bairu e Mata da Fazenda da Floresta.

Foram consideradas também como áreas restritivas: a Fazenda do Exército (área institucionalizada de segurança do exército), Áreas de Cinturão Verde (responsáveis pelo abastecimento de aproximadamente $30 \%$ das hortaliças consumidas no município), zonas de captações de água subterrânea (insignificativa), e o vetor de expansão urbana do município.

Como resultado desta etapa de trabalho foi elaborado um mapa, que foi denominado de Áreas com Restrições para Aterros Sanitários, sobre o qual delimitou - se na escala 1:50.000 os diversos fatores ambientais incompativeis com o aterro,

Posteriormente, com o objetivo de não estender a pesquisa para locais muito distantes da porção urbanizada do município, foi estipulada uma área compreendida num raio de $20 \mathrm{~km}$ a partir do centro geométrico gerador de resíduos (considerado o cruzamento das avenidas Brasil e Rio Branco -. no centro da cidade), como sendo a área economicamente viável para a operação do aterro sanitário.

A área máxima estipulada para pesquisa foi sobreposta as áreas com restrição. Como resultado da exclusão das áreas com restrições e daquelas que ultrapassavam o limite de $20 \mathrm{~km}$, obteve-se zonas remanescentes para pesquisa.

As zonas remanescentes foram analisadas através de fotografias aéreas na escala 1 : 10.000 de 1983 e bases topográficas 1: 50.000 .

A análise de fotografias aéreas consistiu na interpretação da morfologia dos terrenos, a declividade das vertentes e das feiçôes geológicas (principalmente estruturas rúpteis) presentes. Foram analisados a cobertura vegetal e as condições de acesso em geral. Como subsídio de avaliação destas zonas foram considerados os critérios físicos recomendados pela Norma ABNT 13.896/1997 (antiga PN: 603.06-006) "Aterros de Resíduos Não perigosos - Critérios para Projeto, Implantação e Operação".

Com isso, foram delimitadas três regiões que se mostraram favoráveis à implantação do aterro (Figura 3.3 - pag. 40). Estas regiões foram denominadas de:

ÁREA DO IGREJINHA - inserida na micro bacia hidrográfica do Córrego lgrejinha, afluente da margem direita do Rio Paraibuna; 
AREA DA FAZENDA LIMEIRA - inserida entre o Córrego dos Burros e o da Aldeia, afluentes da margem esquerda do Rio Paraibuna;

ÁREA SÃO FIDELIS - situada a Sudeste da mancha urbana, entre as bacias do Rio Marmelo e o Córrego Caetés, afluentes do Rio Paraibuna.

Nas três macro - regióes foram identificados 7 sitios que estavam inseridos em altos topográficos e apresentavam feições de anfiteatros com vertentes de declividade moderada. Aparentemente não tinham ocupação urbana significativa e eram relativamente distantes de cursos de água maiores.

A partir do reconhecimento dos sete sítios foram realizadas investigações de campo. Em relação ao meio físico, as observações foram essencialmente voltadas a morfologia dos terrenos, declividade das vertentes, caracterização da cobertura de solo, análise dos afloramentos rochosos, presença de nascentes de água, comportamento do escoamento das águas superficiais, dimensão da área para recebimento dos resíduos, e disponibilidade de materiais de empréstimo para cobertura e impermeabilização da base.

No meio antrópico, uso e ocupação do solo, distância de núcleos urbanos, e condições de acesso foram consideradas. No biótico, respeitou-se principalmente a presença de matas.

Após as investigações de campo alguns sítios foram excluídos. Nos sítios indicados como favoráveis, foram realizadas investigações de campo mais detalhadas para subsidiar a escolha final.

Finalmente, na área escolhida foram realizados estudos geológico - geotécnicos. Os estudos geológicos consistiram na realização de um mapeamento lito - estrutural, afloramentos rochosos da área com o objetivo de identificar a distribuição geométrica e natureza das descontinuidades do embasamento rochoso, juntamente com a análise do relevo e do escoamento supericicial, que permitiram esboçar o sistema de circulação da água subterrânea na área. As investigações geotécnicas foram executadas através de sondagens à trado e a percussão, abertura de trincheiras com coleta de amostras. Foram realizados ensaios laboratoriais de permeabilidade em amostras deformadas e indeformadas, ensaios de compactação (Proctor Normal), e de granulometria completa.

\subsubsection{Principais caracteristicas das regiões analisadas}

\section{Área do lgrejinha}

Abrange os terrenos inseridos a partir da margem direita do córrego homônimo e da margem esquerda da BR 267 (sentido Lima Duarte). A margem esquerda do córrego foi descartada, devido a proximidade com o divisor de águas da Bacia Hidrográfica do Ribeirão 


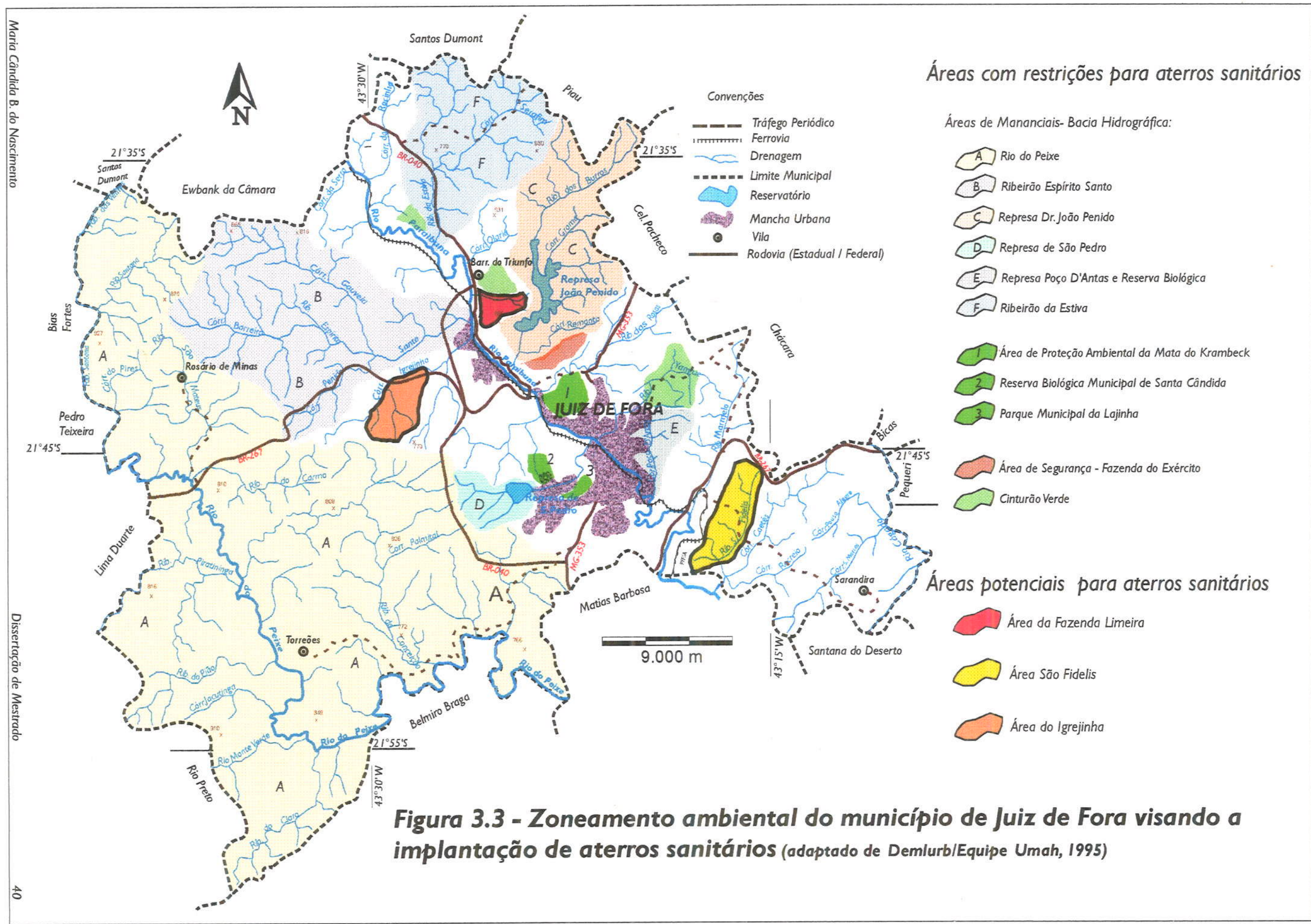


Espírito Santo. A margem direita da rodovia também foi descartada por estar inserida no vetor máximo de expansão urbana do município.

A macro - região apresenta como fatores favoráveis à implantação do aterro: proximidade com a usina de reciclagem e compostagem do município; proximidade com a zona industrial do município; relativamente distante de áreas de mananciais e de núcleos urbanos.

A análise de fotografias aéreas permitiu delimitar 5 sítios denominados de: Sítio lgrejinha; Sítio Fazenda da Serra; Sítio Boa Vista; Sítio Córrego da Serra e Sítio São Luiz.

Após a realização de vistorias em campo, dentre os cinco sítios demarcados através de fotografias aéreas, somente o Sítio lgrejinha foi escolhido para investigações futuras mais detalhadas. Os sítios Fazenda da Serra, Boa Vista e Córrego da Serra foram descartados por estarem circundados por diversos sitios, chácaras e moradias não identificadas nas fotos aéreas disponiveis. A possivel implantação de aterro nestas áreas ocasionaria a esta população vários incômodos, tanto pela implantação como pela operação do aterro, o que geraria manifestações contrárias da própria população e de entidades ambientalistas. Além destes aspectos, foram considerados: o alto valor de desapropriação das terras por estarem em área relativamente adensadas, a proximidade com o Oleoduto da Petrobrás (Sítio Fazenda Velha), restrição da disponibilidade de áreas de empréstimo e vida útil inferior a 10 anos, sem possibilidade de ampliação futura (sítios Fazenda da Serra e Boa Vista). As demais características dos sítios encontram-se listadas na tabela 3.1 . pag. 44.

O fato ocorrido acima mostra como a ausência de materiais cartográficos e fotográficos atualizados acabam comprometendo a etapa inicial das investigações, pois as fotografias aéreas da época indicavam baixo adensamento populacional na região. No caso de Juiz de Fora, as bases topográficas mais recentes eram de 1976 e as fotografias aéreas de 1983

\section{Área da Fazenda Limeira}

$\mathrm{Na}$ área da Fazenda Limeira foi identificado somente um sítio com cerca de 15 hectares, inserido nas cabeceiras de drenagem de um afluente sem denominação (de $1^{a}$ ordem), da margem esquerda do Rio Paraibuna. É limitado a Leste pela bacia Hidrográfica da Represa Dr. João Penido e Fazenda do Exército. A Oeste, pelo Rio Paraibuna.

A principal via de acesso é pela BR 040, sentido Ewbank da Câmara e o secundário, por estrada vicinal não pavimentada com cerca de 500 metros de extensão.

Esta inserido sobre três amplos anfiteatros separados, com fundos planos, onde dois estão inseridos na margem esquerda e um, na margem direita do afluente (foto aérea e fotos 5 a 7 ). As distâncias entre as cabeceiras de drenagem e o Rio Paraibuna variam entre 300 a 1000 metros. 


\section{ÁREA FAZENDA LIMEIRA}

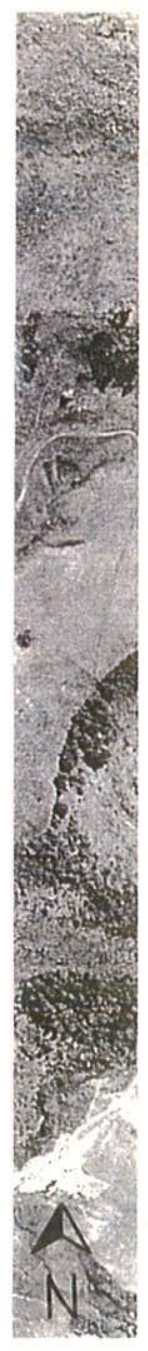

Foto 5 - Vista geral dos anfiteatros em cabeceira de drenagem.
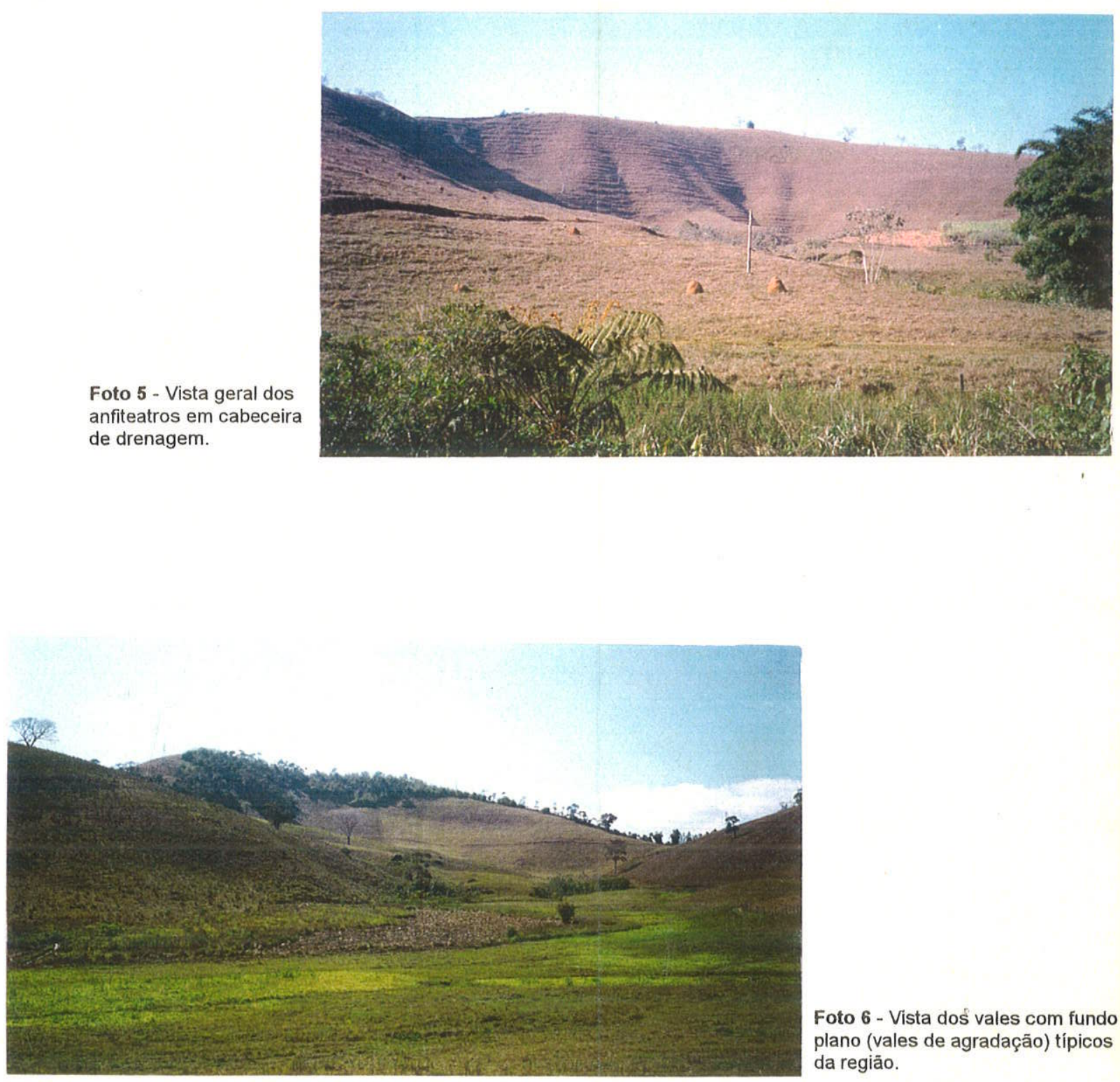

Foto 6 - Vista dos vales com fundo plano (vales de agradação) típicos da região.

Foto 7 - Detalhe do amplo anfiteatro em cabeceira de drenagem com vertentes de inclinação moderada.

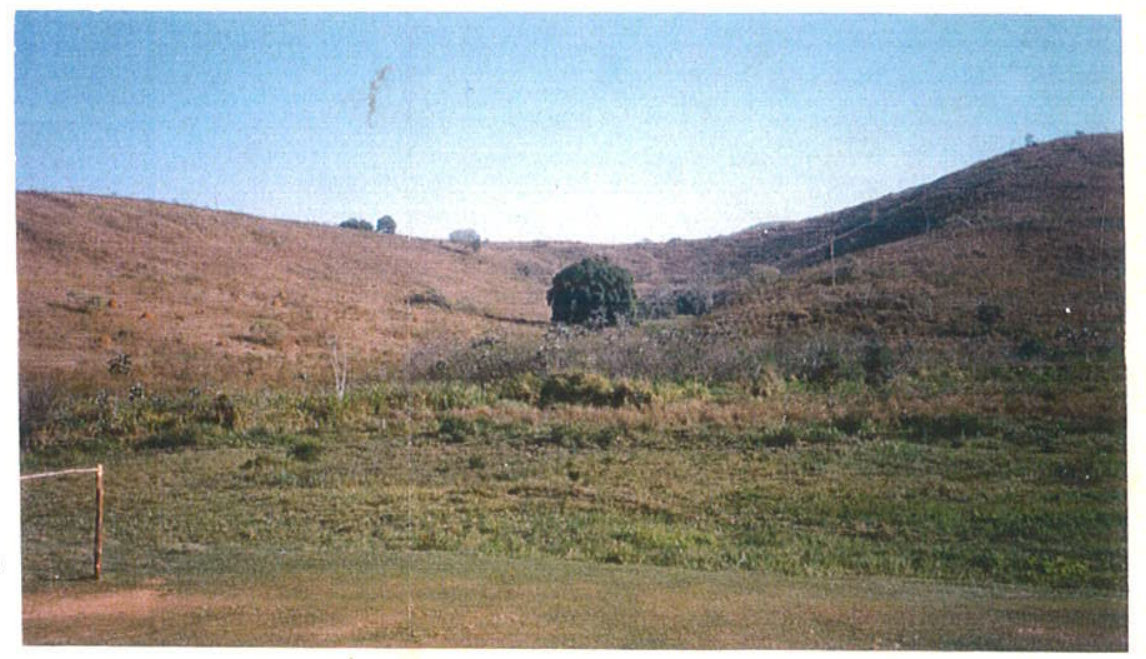




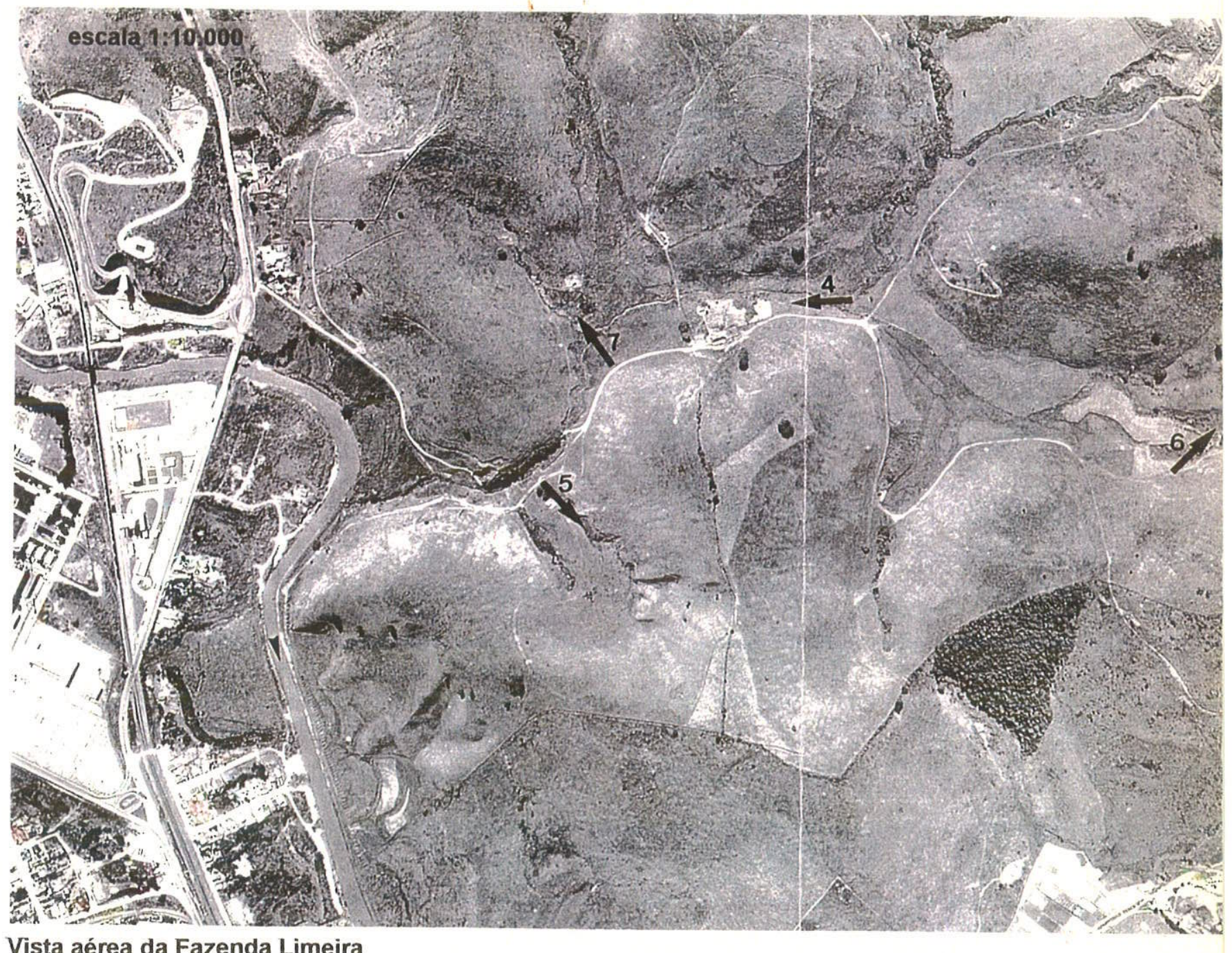

Vista aérea da Fazenda Limeira

Foto 4 - Vista geral do relevo da área Fazenda Limeira.

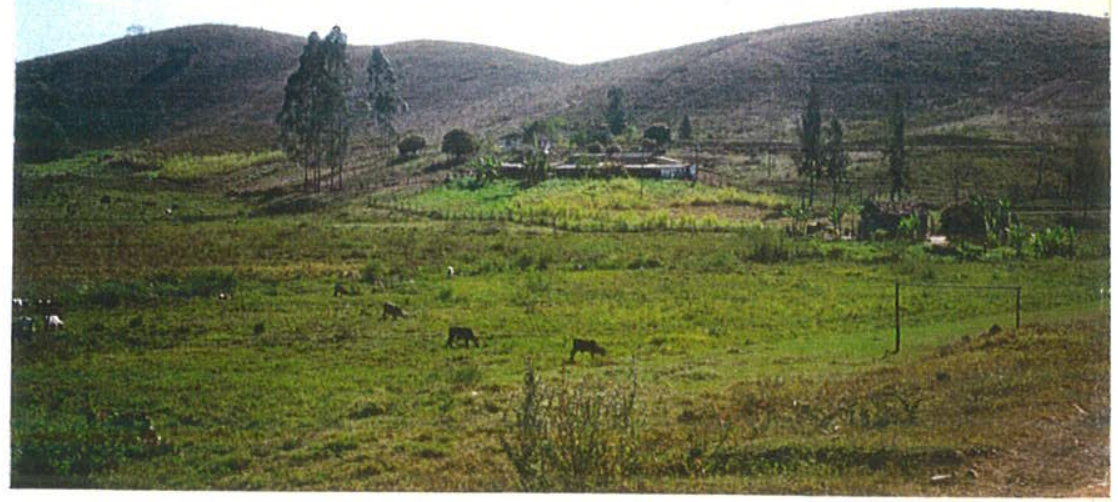


De acordo com Nogueira (1999), o substrato geológico é formado por rochas do Grupo Andrelândia, compostas por sillimanita-biotita gnaisse e muscovita quartzito com intercalações de rochas igneas máficas e félsicas (Figura 3.2 - pag. 34).

O sítio está situado a $14 \mathrm{~km}$ do centro gerador de resíduos e $1 \mathrm{~km}$ do núcleo urbano mais próximo. A cobertura vegetal é dada por gramíneas que são utilizadas para a pastagem das 70 cabeças de gado existentes na fazenda (foto 4 - pag. 42).

Com relação ao sítio da Fazenda Limeira, concluiu-se que ele também era favorável a implantação do aterro por estar relativamente isolado de aglomerados urbanos, apresentava vida útil superior a 10 anos, boas condições de acesso e disponibilidade de áreas de empréstimo. Contrariamente, apresentava anfiteatros separados (o que geraria maior custo de implantação) e a sua proximidade com o Rio Paraibuna (cerca de 300 metros).

\section{Área São Fidelis}

Na área São Fidelis situada a Sudeste da mancha urbana do municipio foram identificados três sitios para aterros. A principal via de acesso é pela BR 267.

Esta inserida no compartimento topográfico que apresenta o relevo mais acidentado do município, onde as declividades das vertentes variam de moderada a alta. O substrato geológico é de rochas pertencentes ao Domínio Juiz de Fora, compostas por granitóides, metassedimentos e gnaisses (Nogueira, 1999).

A região como um todo e a mancha urbana do município são interligadas unicamente pela BR 267, e neste segmento apresenta cerca de $9 \mathrm{~km}$ de trechos bastantes sinuosos, em rampas de declive e pistas estreitas, não apropriado ao tráfego de cargas pesadas

A área como um todo foi descartada para investigações mais detalhadas por: apresentar péssimas condições de acesso, declividade das vertentes moderadas a altas, distante da Usina de Reciclagem; localizar-se distante da área de vetor máximo de expansão urbana (porção Norte da Cidade) 


\begin{tabular}{|c|c|c|c|c|c|c|c|c|}
\hline área & sítio & $\begin{array}{l}\text { declividade } \\
\text { vertentes }\end{array}$ & $\begin{array}{c}\text { dispon. } \\
\text { áreas } \\
\text { empréstimo }\end{array}$ & ocupaçấo & $\begin{array}{c}\text { distância } \\
\text { núcleo urbano } \\
(\mathrm{Km})\end{array}$ & $\begin{array}{l}\text { cond. } \\
\text { acesso }\end{array}$ & $\begin{array}{l}\text { impacto } \\
\text { visual }\end{array}$ & $\begin{array}{c}\text { APTLAO } \\
\text { PARA } \\
\text { ATERRO }\end{array}$ \\
\hline \multirow{5}{*}{ IGREJINHA } & Igrejinha & moderada & boa & pastagem & 1,5 & razoável & baixo & favorável \\
\hline & $\begin{array}{l}\text { Fazenda } \\
\text { da Serra }\end{array}$ & moderada & restrita & residencial & 0 & bom & alto & desfavoráve \\
\hline & Boa Vista & moderada & restrita & residencial & 0 & born & alto & desfavoráve \\
\hline & $\begin{array}{l}\text { Córrego } \\
\text { da Serra }\end{array}$ & moderada & restrita & residencial & 0 & bom & alto & desfavoráve \\
\hline & São Luiz & moderada & boa & pastagem & 2,0 & bom & alto & destavorave \\
\hline $\begin{array}{l}\text { FAZENDA } \\
\text { LIMEIRA }\end{array}$ & $\begin{array}{l}\text { Fazenda } \\
\text { Limeira }\end{array}$ & moderada & boa & pastagem & 1,0 & bom & baixo & Savorável \\
\hline SĀO FIDELIS & $\begin{array}{l}\text { Säo } \\
\text { Fidelis }\end{array}$ & $\begin{array}{c}\text { altal } \\
\text { moderada }\end{array}$ & boa & pastagem & 0,4 & péssimo & médio/alto & desifavoráve \\
\hline
\end{tabular}

Tabela 3.1: Síntese dos sítios analisados (Adaptado de Demlurb/Equipe Umah, 1995).

\subsubsection{Seleção final do sítio}

Dentre os sete sítios analisados, somente o Sítio Fazenda Limeira e o Sítio Igrejinha apresentaram apłidão para a locação do aterro sanitário.

O sitio Fazenda Limeira foi excluido para a realização de investigações geológico geotécnicas mais detalhadas. A justificativa atribuída para a exclusão foi pelo elevado custo de implantação do aterro (pela incidência de anfiteatros separados) e pela sua proximidade com o Rio Paraibuna (que varia de 300 a 1000 metros).

As condições geomorfológicas, geológicas e hidrológicas aparentemente são favoráveis à implantação de aterros. Discorda-se aqui da justificativa atribuída para a exclusão da área pelo elevado custo da obra, uma vez que as investigações geológico - geotécnicas não foram aprofundadas, como também não foi realizado o estudo de viabilidade econômica do empreendimento em áreas alternativas, no caso, da área da Fazenda Limeira.

Diante do exposto, o Sítio Igrejinha foi o que apresentou aptidão mais adequada para a implantação do aterro e este foi objeto de investigações geológico - geotécnicas mais detalhadas para a confirmação de sua aptidão e consolidar sua escolha.

\subsubsection{Caracterização física do sítio lgrejinha}

O diagnóstico do meio físico realizado no sítio abrangeu os seguintes temas: geomorfologia, geologia e cobertura superficial do solo.

A área é utilizada para pastagem e plantio de milho. A vegetação praticamente inexiste, com exceção das partes mais elevadas, no limite da bacia (foto aérea e fotos 8 a 13).

O sítio sítua-se na cabeceira de drenagem de um tributário (sem denominação) da margem direita do Córrego Igrejinha. O local para disposição é caracterizado por apresentar anfiteatros 

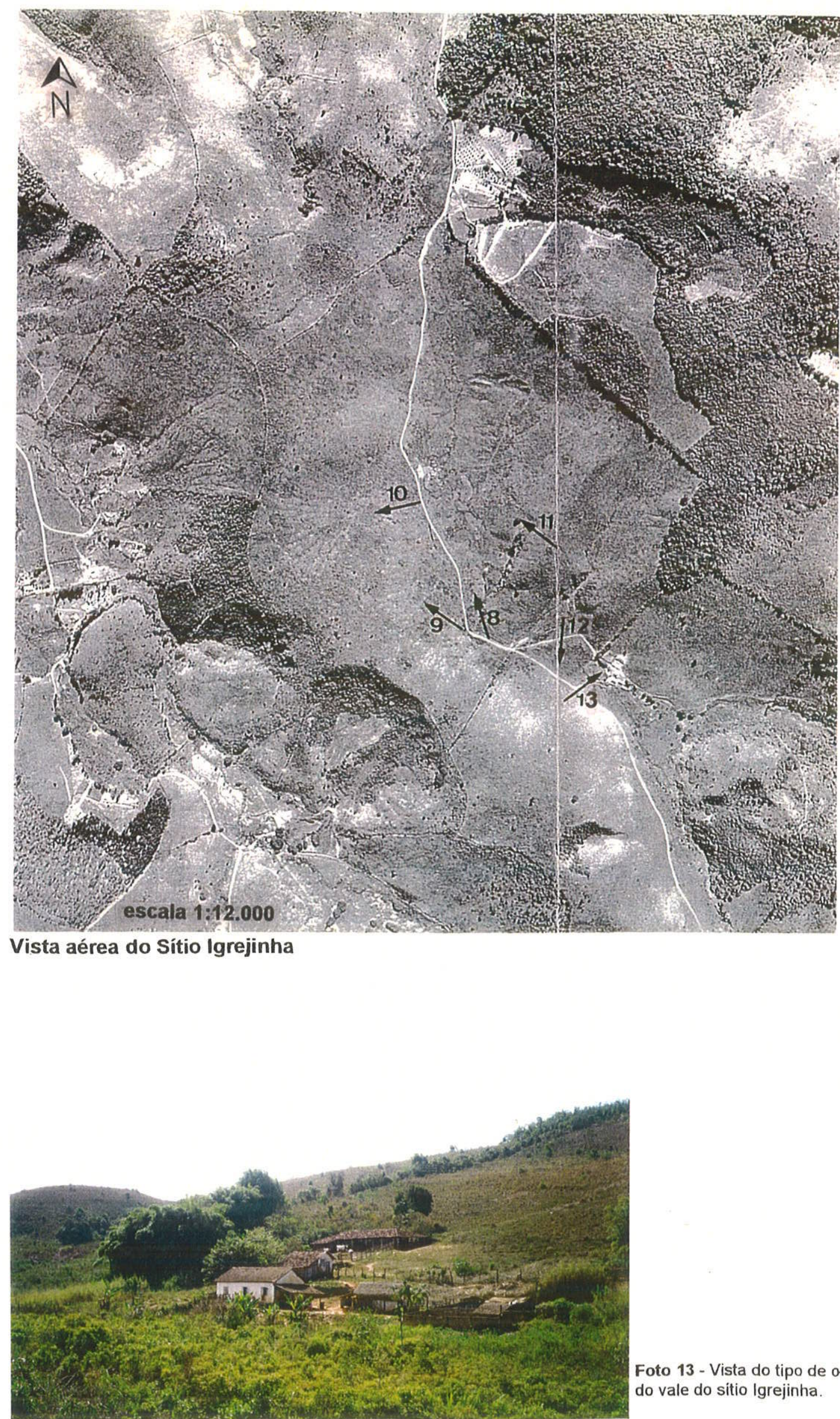

3 - Vista do tipo de ocupação Foto 13 - Vista do tipo
do vale do sitio Igrejinh

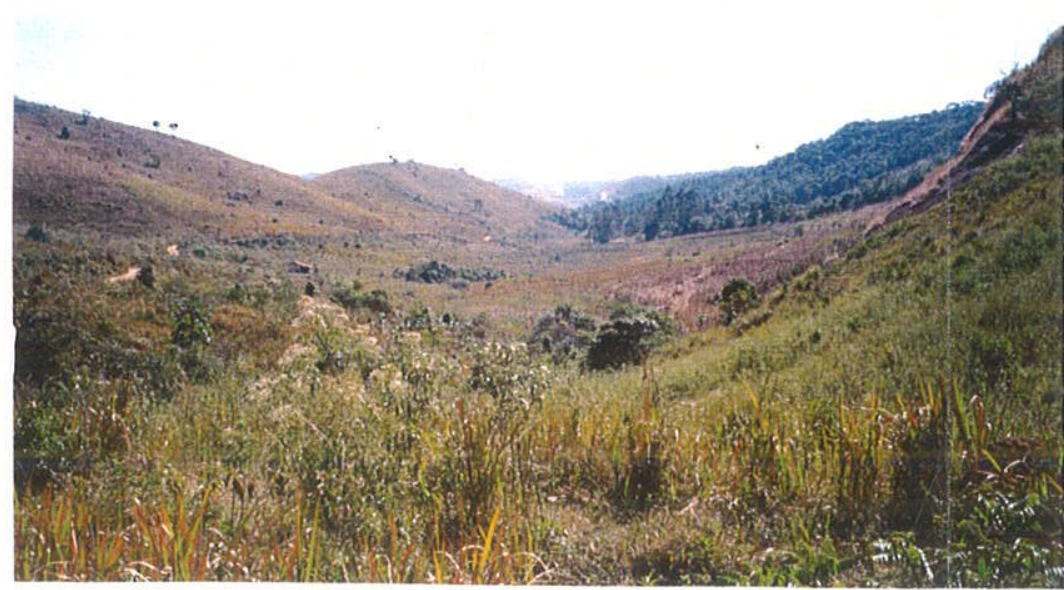

Foto 8 - Vale aberto com fundo plano adjacente ao sítio Igrejinh

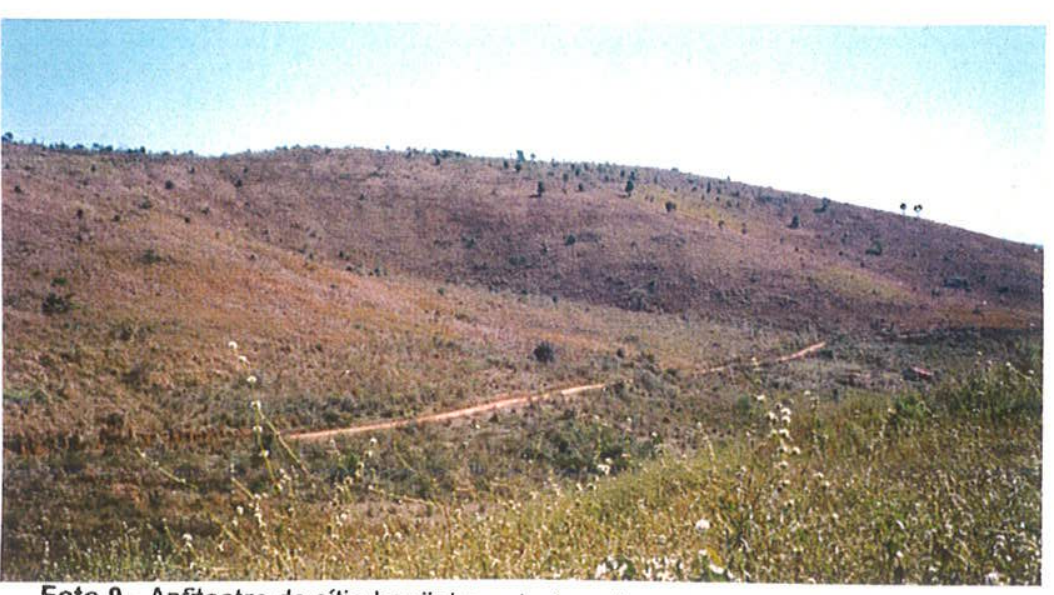

a inclinaçăo moderada das vertentes e a grande área o aterro. Notar
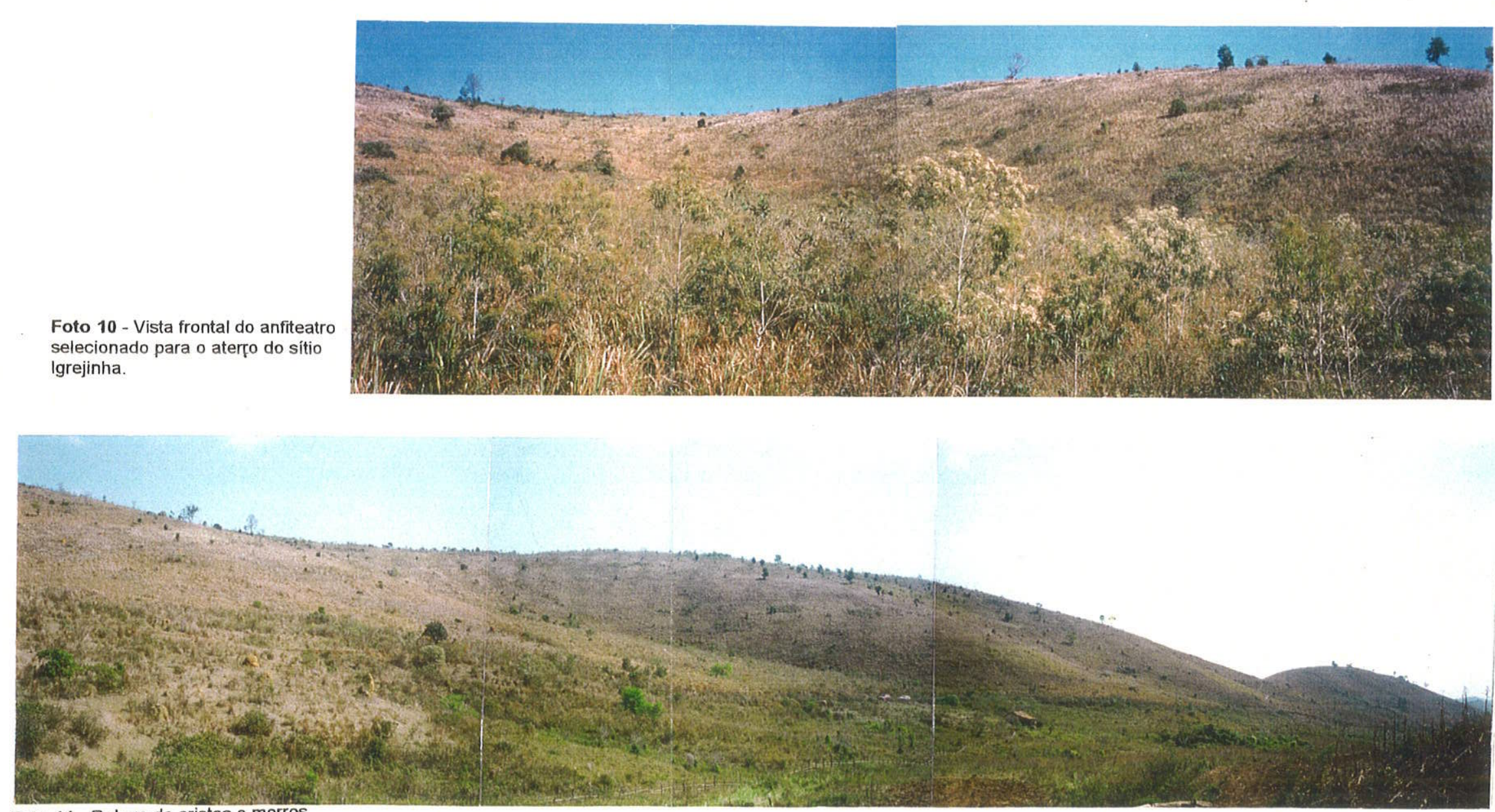

\section{Foto 11 - Relevo de cristas e morros}

arredondados com amplos anfiteatros

em cabeceiras de
do sitio Igrejinha.

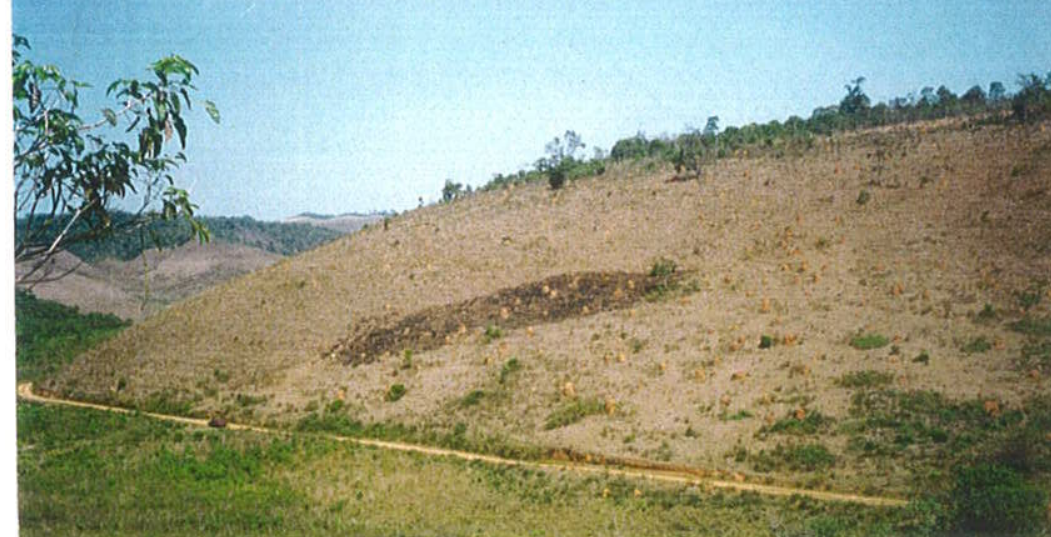


interligados de diferentes dimensões, totalizando um área de aproximadamente 18 hectares.

A interligação destes anfiteatros se dá através de morros de maiores amplitudes, favorecendo com isso a aquisição de áreas de empréstimo nas proximidades (foto 12). Na parte inferior há um pequeno córrego, de pequena vazão.

\section{Geologia estrutural}

Com o objetivo de identificar o condicionamento estrutural do relevo, da cobertura pedológica e do aqüífero, procedeu-se o mapeamento lito-estrutural dos afloramentos rochosos da área, assim como, a análise da geometria de feições de relevo e da rede de drenagem em carta topográfica e fotografias aéreas. Através deste mapeamento lito-estrutural e análise geomorfológica, apresenta-se um modelo de gênese do relevo e comportamento hidrogeológico da água subterrânea.

\section{- Estruturas geológicas identificadas}

\section{Bandamento Composicional e Foliação Milonítica}

A superfície estrutural (descontinuidade) mais importante na área, do ponto de vista da freqüência e penetratividade é o bandamento composicional (bandamento gnáissico) paralelo à foliação milonítica. Macroscopicamente estas superfícies são notadas pela alternância rítmica de leitos leucocráticos (predominância de quartzo e feldspatos), mesocráticos (feldspatos, quartzo, piroxênios e biotita em porcentagens semelhantes) e melanocráticos (predominância de biotita e hornblenda). O contato entre estas bandas é freqüentemente gradativo. A espessura destas bandas é desde milimétrica a decimétrica, raramente métrica, com maior incidência de leitos entre 5 e 20 $\mathrm{cm}$. Estas superfícies exibem grande continuidade lateral e variação na espessura em função de estiramento e boudinagem (foto 14).

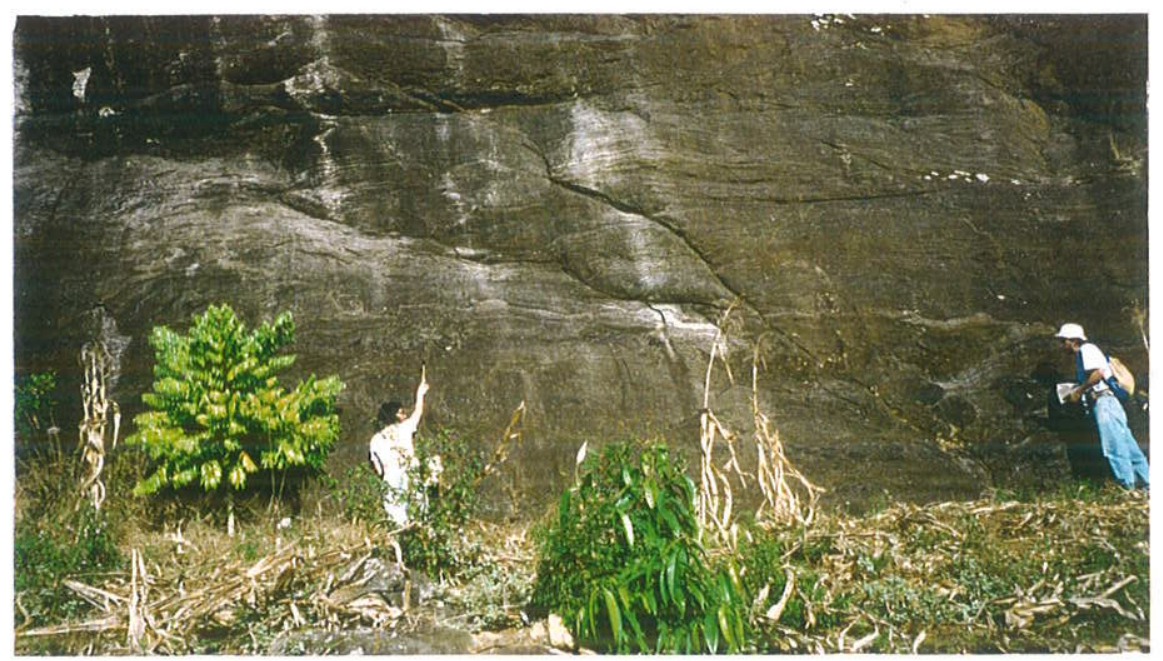

Foto 14 -Margem esquerda do Córrego Igrejinha, nas proximidades da área selecionada. Afloramento exibindo as fraturas de cisalhamento dúctil-rúptil inclinadas obliquamente a foto e o bandamento gnáissico sub-horizontal . 
Associa-se a origem desta foliação milonitica a um intenso processo de transposição tectônica com dobramento isoclinal e cisalhamento dúctil, o que levou à paralelização entre xistosidade e bandamento, ao estiramento e boudinagem dos leitos composicionais, imprimindo um intenso imbricamento tectonico de rochas granulíticas ortoderivadas e supracrustais (metassedimentos) de alto grau metamórfico, característica regional do Complexo Juiz de Fora (Heilbron, 1993). A presença de dobras intrafoliais isoclinais a similares, com chameiras cônicas, planos axiais paralelos ao bandamento composicional e mergulhos entre 20 e $40^{\circ}$ para SE, evidenciam a presença de grandes dobras recumbentes, associadas à transposição e cisalhamento dúctil com vergência para NW e com eixos de baixo mergulho para NE e SW (figura 3.4) A orientação geral do bandamento composicional e foliação milonítica na área lgrejinha possui direções entre N30-70E e mergulhos de $10^{\circ}$ a $40^{\circ}$ para SE, indicando a ondulação destas superficies (figura 3.4).

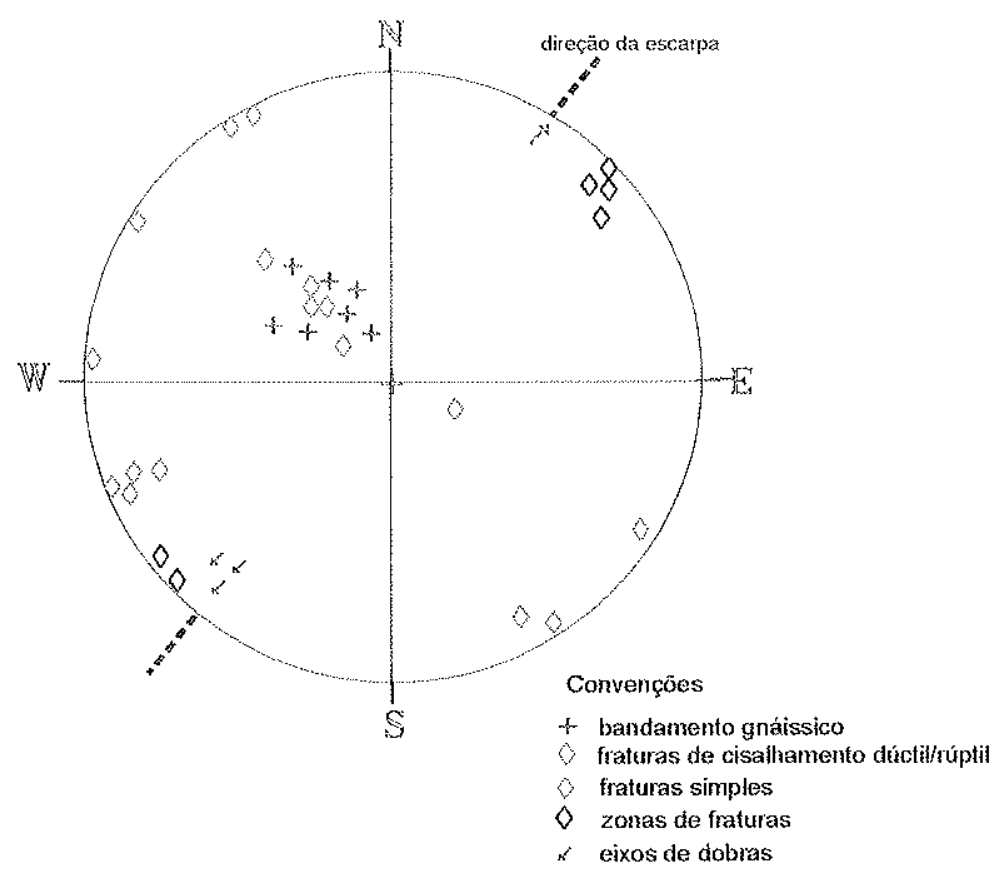

Figura 3.4 - Projeção estereográfica das medidas estruturais do sítio lgrejinha

\section{Sistema de Fraturamento}

De modo geral, a área investigada apresenta baixa incidência de estruturas disruptivas superimpostas às foliações metamórficas acima descritas. Identificou-se os seguintes conjuntos de fraturas ( tabela 3.2 - pag. 49) que compõem o sistema de fraturamento dos gnaisses miloníticos da área (a classificação de fraturas segue a nomenclatura de Ramsay e Huber, 1987): 


\section{Fraturas de cisalhamento dúctil-rúptil}

Este conjunto de descontinuidades representa uma fase de deformação superimposta e tardia ao desenvolvimento do bandamento gnássico-milonítico, fato evidenciado pela dobras de arrasto do bandamento geradas pelo movimento relativo dos blocos adjacentes aos planos de ruptura. Atribui-se a característica tardia em relação ao dobramento e metamorfismo pelo fato da presença de micas e preenchimento quartzo-feldspático de grande parte destes planos, formando freqüentemente zonas de cisalhamento com espessuras centimétricas a milimétricas, com orientação desde levemente obliquas a transversais em relação a foliação principal.

Estas fraturas possuem comprimento métrico a decamétrico e espaçamento decamétrico. Sua atitude geral predominante é N30-50E 10-45SE, e localmente, com mergulhos altos e moderados para NW (tabela 3.2 e figura 3.4), formando superfícies onduladas, típicas de fraturas sigmoidas desenvolvidas tardiamente em relação ao dobramento e transposição dos gnaisses, concordando com a vergência geral para NW.

\section{Fraturas simples}

Esta categoria de frấuras apresenta dois conjuntos de orientações preferenciais. Um é formado por planos de ruptura com comprimento métrico e espaçamento decamétríco, com direçäo entre NS e N30W e mergulhos sub-verticais (figura 3.4). O segundo possui direção geral N50-60E e mergulho também subvertical, com ocorrência preferencial nas bandas quartzo feldspáticas, onde forma rupturas de comprimento centimétrico a decimétrica com espaçamento decimétrico.

As fraturas simples caracterizam-se por não possuirem preenchimento, o que sugere origem através de esforços compressivos em nível crustal raso. O controle litológico, as dimensões reduzidas e a baixa freqüência, imprimem pequena expressividade em área deste tipo de fratura.

\section{Zonas de fraturas simples e preenchidas}

Esta categoria de fraturas representa as estruturas disruptivas mais importantes da área em freqüência e dimensões. Ocorre na forma de agrupamentos de fraturas simples e preenchidas, formando zonas fraturadas com espessuras entre alguns centímetros até cerca de $3 \mathrm{~m}$. Estas zonas fraturadas possuem recorrência decamétrica. Internamente nestas faixas fraturadas, as rupturas possuem espaçamento centimétrico e comprimento desde decimétrico a métrico, localmente decamétrico, formando um padrão escalonado a entrelaçado. Cerca de $40 \%$ destas fraturas apresentam preenchimento com quartzo, caracterizando venulações, com espessuras miltimétricas, o que permite associar a gênese destas descontinuidades à esforços trativos em nivel raso na crosta.

Sua atitude geral é N40-45W, com mergulhos sub-verticais tanto para NE como para SW (tabela 3.2 e figura 3.4 ). 


\begin{tabular}{|c|c|c|c|c|}
\hline bandamento & $\begin{array}{l}\text { fraturas de } \\
\text { cisalhamento } \\
\text { dúctil-rúptil }\end{array}$ & fraturas simples & ** zonas de fraturas & $\begin{array}{c}\text { eixos de dobras } \\
\text { intrafoliais ao } \\
\text { bandamento }\end{array}$ \\
\hline N31E / 25SE & N45E / 27SE & N01E sv / SE & N44W /80SW & $\mathrm{S} 39 \mathrm{~W} / 20^{\circ}$ \\
\hline N56E / 30SE & N46E / 30SE & N24W / 80NE & N39W $/ 75 S W$ & $\mathrm{~S} 41 \mathrm{~W} / 15^{\circ}$ \\
\hline N46E / 40SE & N42E / 48SE & ${ }^{*}$ N61E / 80NW & N42W / 85SW & $\mathrm{N} 45 \mathrm{E} / 10^{\circ}$ \\
\hline N51E / 22SE & N30E / 15SE & N56E / sv & N40W / 87NE & $\mathrm{N} 50 \mathrm{E} / 15^{\circ}$ \\
\hline \multirow[t]{4}{*}{ N21E / 35SE } & N50E / 25SE & & N46W / sv & \\
\hline & N45E / 27SE & & & \\
\hline & N30E / 8NW & & & \\
\hline & N32E / sv & & & \\
\hline
\end{tabular}

OBS: * conjunto restrito a nivel mais quartzo feldspático, espaçamento decimétrico ** fraturas médias a longas concentradas em faixas de 10 a $20 \mathrm{~cm}$ de espessura.

Tabela 3.2 Medidas estruturais do Sítio Igrejinha (em relação ao Norte Geográfico)

\subsubsection{Condicionamento estrutural da paisagem}

\section{Orientação de vales e cristas}

A distribuição planimétrica de feições de relevo positivas, como eixos maiores de morrotes, morros e cristas lineares, assim como, de feições de entalhamento, como talvegues lineares, eixos maiores de vales de fundo plano e ravinamentos, foi obtida para a área investigada e arredores, sobre a base topográfica 1:50.000 (figura 3.5)

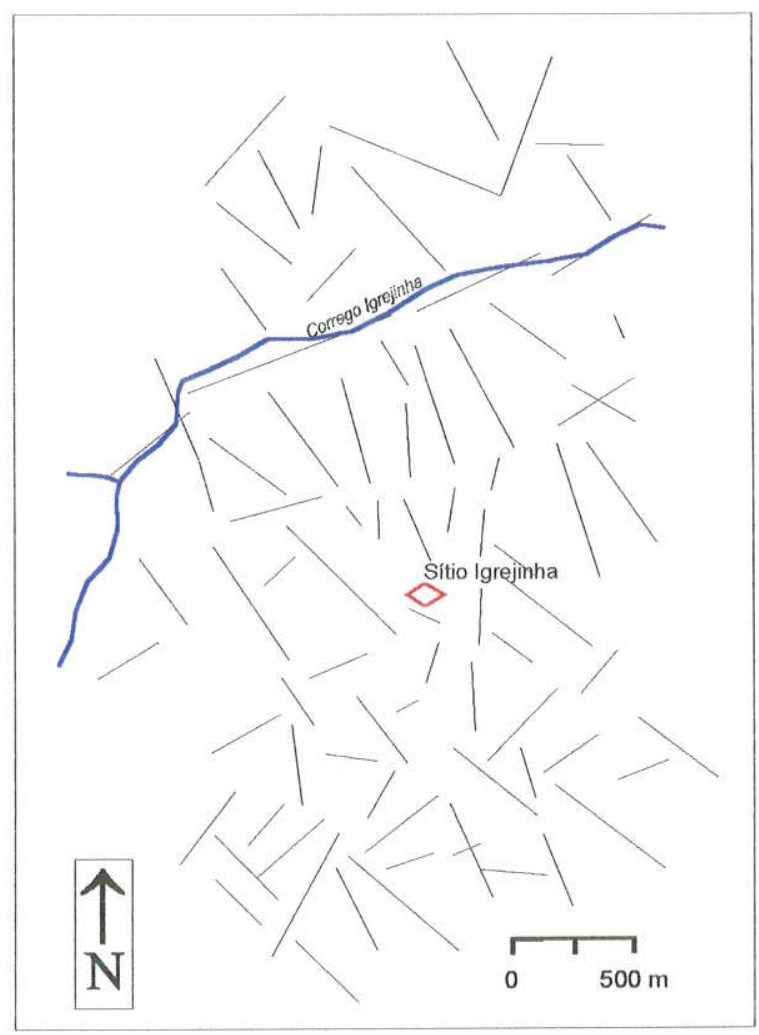

Figura 3.5 - Mapa de fotolineamentos do Sítio Igrejinha 
Nota-se duas orientações preferenciais dos lineamentos acima citados (figura 3.6). A direção predominante alinha-se entre N40-50W, seguida da concentração a N40-60E. Alinhamentos menos expressivos ocorrem em torno de NS e próximo a EW.

Ocorrência máxima em um mesmo intervalo angular de $10^{\circ}=11$

Tamanho máximo em um mesmo intervalo angular de $10^{\circ}=11$

Valor do círculo máximo $=14,58772 \%$

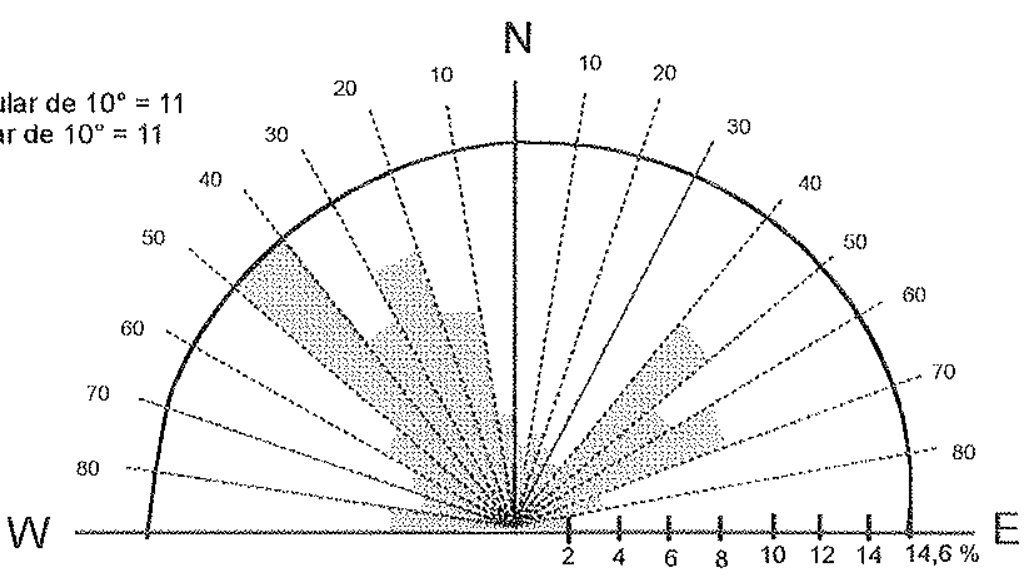

Figura 3.6 -. Histograma de fotolineamentos do Sítio Igrejinha. (obs: as feições lineares representam linhas de cristas e fundos de vales).

Esta distribuição de orientações de feições lineares do relevo coincide com as direções preferenciais de estruturas planares medidas na região da Igrejinha. Com base nesta associação geométrica, aliada à observações de campo, atribui-se a direção preferencial N40-50W ao intemperismo e entalhamento concentrado ao longo das descontinuidades subverticais das zonas de fraturas simples e preenchidas, acima descritas. O comprimento maior destas lineações reflete a extenção maior detectada nas zonas de fraturas a N30-40W. A concentração de lineamentos entre N40-60E é associada à erosão preferencial ao longo de superfícies do bandamento gnássico e da foliação milonítica, e secundariamente, sobre fraturas de cisalhamento dúctil-rúptil, pois estas, possuem freqüência de ocorrência menor, em relação aos planos do bandamento.

\section{Formação de matacões e maciços de esfoliação esferoidal}

A paisagem predominante na área investigada é de morros e morrotes com cristas arredondadas e encostas predominantemente convexas, e côncavas junto à anfiteatros de cabeceiras de drenagem. Esta morfologia reflete um manto de intemperismo com espessura extremamente variável (desde rocha quase exposta até cerca de $50 \mathrm{~m}$ ), que recobre grandes matacões e maciços tipo "pão de açúcar" gerados por esfoliação esferoidal (foto 15 - pag. 51). Este processo de intemperismo possui forte controle estrutural. Os matacões possuem forma genérica de elipsóides com eixo maior paralelo ao bandamento gnássico. O esquartejamento da rocha sã em matacões é imposto pelo reticulado formado principalmente pelas intersecções entre o bandamento gnáissico e as zonas de fraturas simples e preenchidas e as fraturas de cisalhamento dúctil-rúptil.

Esta característica morfológica do substrato rochoso condiciona grandes variações laterais na espessura do manto de intemperismo. $\mathrm{Na}$ área do local proposto para instalação do aterro, 
detectou-se uma variação de no mínimo entre 6 a 8m de cobertura síltico-argilosa, com níveis arenosos e conglomeráticos nas proximidades das encostas e de no mínimo de $6 \mathrm{~m}$ de material predominantemente síltico-argiloso nas encostas. Estas medidas não devem ser generalizadas para toda área, em função da provável grande variação lateral da espessura da cobertura.

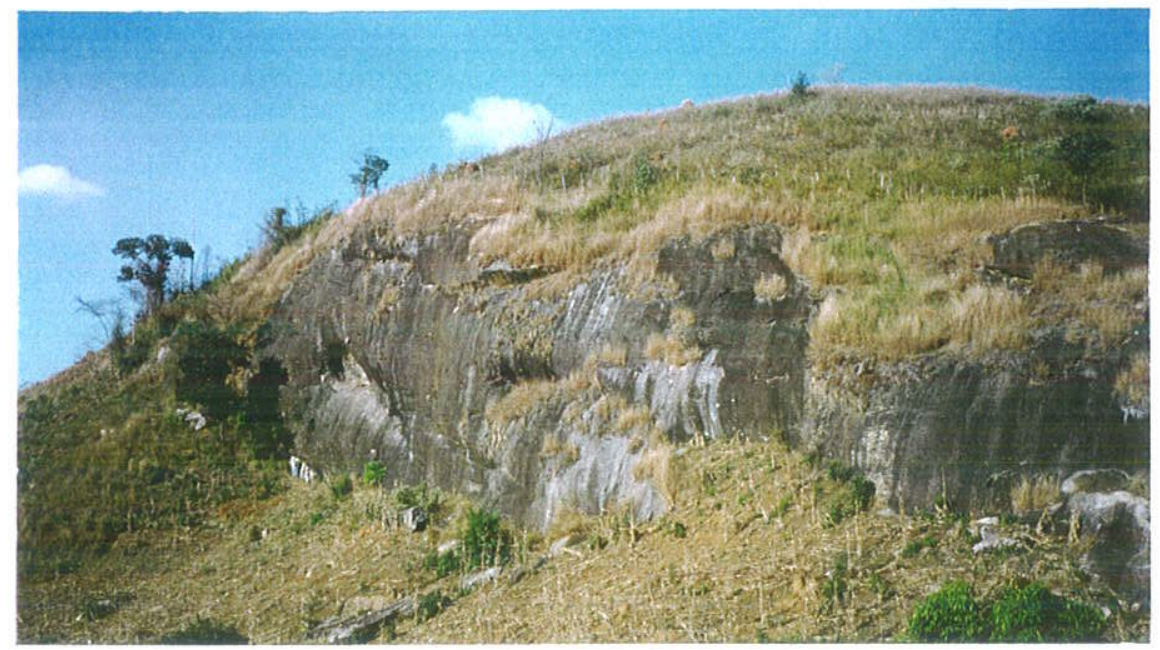

Foto 15 - Aspecto típico dos gnaisses da região do sítio Igrejinha com grandes maciços de esfoliação esferoidal semi-aflorantes.

\section{Modelo de circulação da água subterrânea no Sítio Igrejinha}

A identificação da distribuição, geometria e natureza das descontinuidades, juntamente com a análise do relevo e do escoamento superficial, permite esboçar o sistema de circulação da água subterrânea na área investigada.

Devido a espessa cobertura pedológica sobre os gnaisses, cobertura esta, de composição desde síltico-argilosa a arenosa com pedregulhos e fragmentos centimétricos líticos, define-se dois tipos de aqüíferos contrastantes. Um superior, com porosidade intergranular, restrito ao manto de intemperismo, e outro inferior, com porosidade de descontinuidades planares (fraturas e superfícies de bandamento), associado ao gnaisse milonítico (conforme a classificação de aqüíferos de Freeze e Cherry, 1979).

O aqüífero com porosidade intergranular é caracterizado por uma zona vadosa (acima do N.A.) com profundidade estimada em no mínimo de 10 a $20 \mathrm{~m}$ nas proximidades das cristas, e de 7 a 15 nas encostas (com base em perfurações a trado na área e observações em cortes de encostas ao longo de estradas). Nos fundos dos vales o aqüífero é raso, evidenciado pela presença de manchas umedecidas, zonas encharcadas e pequenos córregos. Este aqüífero é caracterizado por horizontes de maior e menor permeabilidade, condicionados pela alternância entre níveis predominantemente argilosos e arenosos. Esta estratificação da porosidade é produto do intemperismo de leitos ricos em quartzo (níveis arenosos), alternados com leitos predominantemente micáceos e feldspáticos do gnaisse original. Estas permeabilidades 
contrastantes entre niveis ao longo da cobertura pedológica favorece a ocorrência de aqüiferos suspensos sazonais, com maior incidência no período de chuvas.

O aqüifero fraturado associado aos matacões e maciços de gnaisse subjacentes ao manto de intemperismo possui baixa permeabilidade, restrita à fraturas interconectadas e abertas em função do alivio de carga. Atribui-se baixa permeabilidade ao aqüífero de fraturas no gnaisse da Igrejinha, devido à ausência de um extensivo sistema de descontinuidades interconectadas e com abertura. A porosidade mais desenvolvida deve estar associada ao conjunto de fraturas da zona de fraturas simples acima caracterizada, seguida pelas fraturas de cisalhamento dúctil-rúptil. A circulação de água pelos matacões e maciços rochosos deve seguir as rotas de maior permeabilidade definidas pelas intersecções entre o bandamento gnáissico e as fraturas de cisalhamento dúctil-rúptil, assim como, com as zonas de fraturas, definindo rotas com direção predominante NE-SW, no primeiro caso, e rotas com direção NW-SE, no caso das zonas de fraturas. A circulação de água pela rocha sã deve ser bastante reduzida, em função da pequena extensão das principais fraturas detectadas. Este fato diminui a probabilidade da interconecção entre capilares condicionados pelas interseções, o que poderia formar longas rotas de maior permeabilidade acompanhando alternadamente as duas direções de interseç̧ão acima citadas. A probabilidade de ocorrência destas rotas é diminuida ainda, devido à característica gradativa muito freqüente entre leitos gnássicos, aliado à interrupção lateral destas descontinuidades, devido ao pinçamento tectônico destes. O caráter gradativo entre bandas gnáissicas elimina a definição de uma superfície, o que por sua vez, dificulta, ou até impede, a abertura (descolamento) dos blocos adjacentes a esta, durante o processo de expansão aliado ao alivio de carga do maciço rochoso ao sofrer soerguimento e exposição a níveis imtempéricos. Esta abertura submilimétrica de descontinuidades é fundamental para dar início à instalação da porosidade secundária em maciços rochosos e do respectivo aqüifero de fraturas. Grande parte das fraturas de cisalhamento dúctilrúptil também tem sua abertura por expanão impedida, ou dificultada, pela presença de preenchimento quartzo-feldspático e uma zona de cisalhamento dúctil com recristalizaçäo de minerais metamórficos ao longo destas, formando contatos gradativos entre os blocos adjacentes.

A consideração sobre a baixa permeabilidade do maciço gnáissico, acima exposta, é suportada pela observação de paredes escavadas em pedreiras nas proximidades de Juiz de fora (foto 2 - pag. 33), onde em tipo litológico e padrão estrutural semelhante ao da área da lgrejinha, notou-se a incidência muito restrita de pontos com surgência de água.

Por último, deve-se notar, que a ocorrencia de fraturas de alívio de carga (normalmente sub-horizontais e de grande área) nos gnaisses da área da lgrejinha, é praticamente ausente, tornando o maciço gnássico ainda menos recortado por extensas descontinuidades que poderiam incrementar a porosidade secundária do maciço. 


\subsubsection{Aspectos geotécnicos}

As sondagens (trado e a percussão) e os ensaios realizados mostraram que a camada superficial do sítio apresenta uma espessura que varia de 1 a 7 metros, composta por solo de textura argilo-siltosa com areia fina.

Ensaios de granulometria completa indicaram que os solos neste horizonte são constituídos predominantemente por argila e silte (variando entre 50 a $75 \%$ ) e o restante composto por areia fina (em média de 20\%) e areia grossa (em média de 5 a 10\%). Os ensaios de permeabilidade realizados em amostras indeformadas e deformadas, extraidas a profundidades de 1,5 a 1,9 metros, indicaram um coeficiente que varia entre $1,24 \times 10^{-3}$ e $5,9 \times 10^{-5} \mathrm{~cm} / \mathrm{s}$ respectivamente.

De acordo com Cetesb (1992), os solos que apresentam estes coeficientes de permeabilidade são classificados respectivamente como solos com boa drenagem (permeáveis) e solos de drenagem má (solos menos permeáveis). Portanto, a camada superficial do substrato do sitio Igrejinha apresenta um comportamento bastante irregular quanto a sua permeabilidade, espessura e granulometria.

Os ensaios de SPT mostraram que este horizonte apresenta consistência mole.

As características geotécnicas acima apresentadas correspondem aos parámetros tipicos de latossolos conforme Nogami e Villabor (1995).

As sondagens a percussão realizadas nas vertentes do anfiteatro não atingiram o nivel da água até 20 metros de profundidade.

\subsubsection{Conclusões}

A área de Igrejinha apresenta baixo índice de ocorrência de estruturas disruptivas. A descontinuidade mais penetrativa é o bandamento gnáissico associado à foliação milonítica. Apesar desta alta freqüência de superfícies, sua função hidráulica é reduzida devido à forte tendência de contatos gradativos entre as bandas. O conjunto de fraturas mais expressivo em dimensões é formado pelas zonas de fraturas simples e preenchidas com atitude geral N40-45W subvertical. Individualmente estas fraturas possuem dimensões reduzidas e baixo grau de interconecção, contribuindo pouco com o incremento da permeabilidade secundária do gnaisse. Considera-se que - aqüifero fraturado na área investigada possui permeabilidade muito reduzida. Desta maneira, a água subterrânea deve concentrar-se na cobertura pedológica, constituindo o aqüifero mais importante na área investigada. Este aqüífero, do tipo intergranular, deve apresentar boa capacidade de filtragem nos leitos areno-siltosos. A permeabilidade desta cobertura é muito variável, com aqüíferos suspensos locais e sazonais devido a alternância de horizontes silticoargilosos e areno-siltosos com fragmentos líticos. Ensaios revelaram valores de permeabilidade da cobertura entre $1,24 \times 10^{-3}$ e $5,9 \times 10^{-5} \mathrm{~cm} / \mathrm{s}$. Na época da investigação (outubro, 1995) o nivel da água nas vertentes do anfiteatro estava abaixo de 20 metros de profundidade. 
O relevo da área investigada apresenta forte controle estrutural, onde morros e morrotes indicam a presença de matacões e maciços eliptícos imersos no manto de alteração, o qual exibe espessuras na área proposta para o futuro aterro, de no mínimo 5 a 8m, estimando-se zonas com espessuras maiores de cobertura pedológica.

\subsection{Município de Ilhéus, BA}

\subsubsection{Caracterização geral do município de Ilhéus}

O município de Ilhéus, inserido na região Sudeste do Estado da Bahia, apresenta uma área de $1.712 \mathrm{~km} 2$ compreendida entre os paralelos de $14^{\circ} 26^{\prime}$ e $15^{\circ} 07^{\prime}$ Sul ; e entre os meridianos de $39^{\circ} 02^{\prime}$ e $39^{\circ} 30^{\prime}$ Oeste (figura 3.7).

É delimitado a Leste pelo Oceano Atlântico (entre a foz do Córrego Sergi/Norte, e Rio Acuípe/Sul) (foto 16); a Sul pelo Município de Una; a Oeste pelos municípios de Buerarema, Itabuna, Itajuípe, Coaraci e Ibirapitanga; e a Norte pelos municípios de Aureliano Leal, Itacaré e Uruçuca (figura 3.7).

As principais vias de acesso são a Rodovia BA - 415, que interliga as cidades de llhéus e Itabuna, e a BA - 001, que interliga Ilhéus a Canavieiras.

Em 1998, abrigava uma população urbana de 184.830 habitantes que gerava cerca de 96,2 toneladas diárias de resíduos urbanos compostos essencialmente por matéria orgânica (72\%), papel/papelão (9\%), plástico $(9 \%)$ e metais $(3,5 \%)$. Nos períodos de férias escolares, o número da população flutuante atingia em média de 37.000 turistas, que acrescentava em média 20 toneladas de resíduos diariamente (Conder/Equipe Umah, 1997).

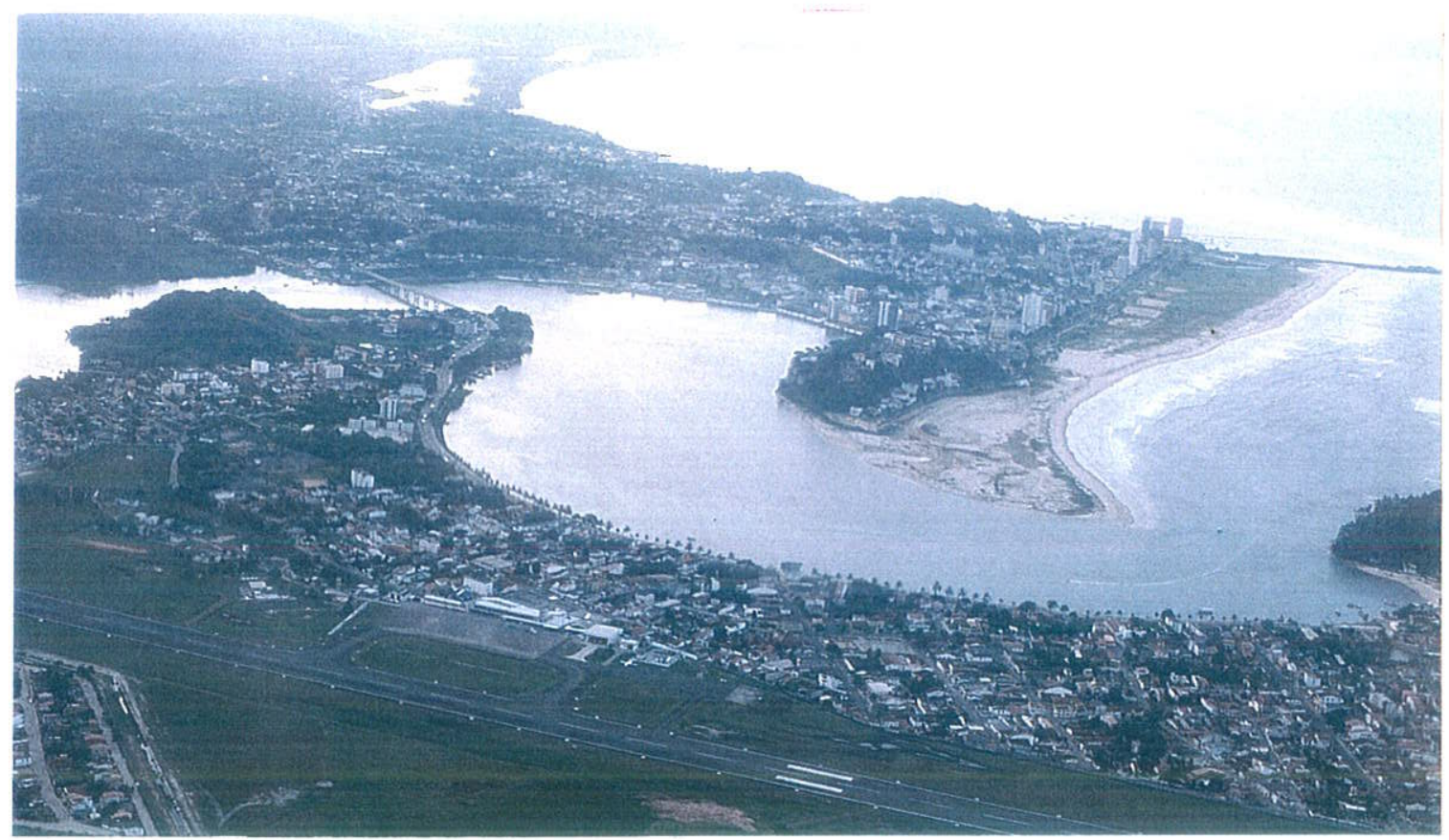

Foto 16 - Vista aérea da cidade de Ilhéus e da desembocadura do Rio Cachoeira no mar. 


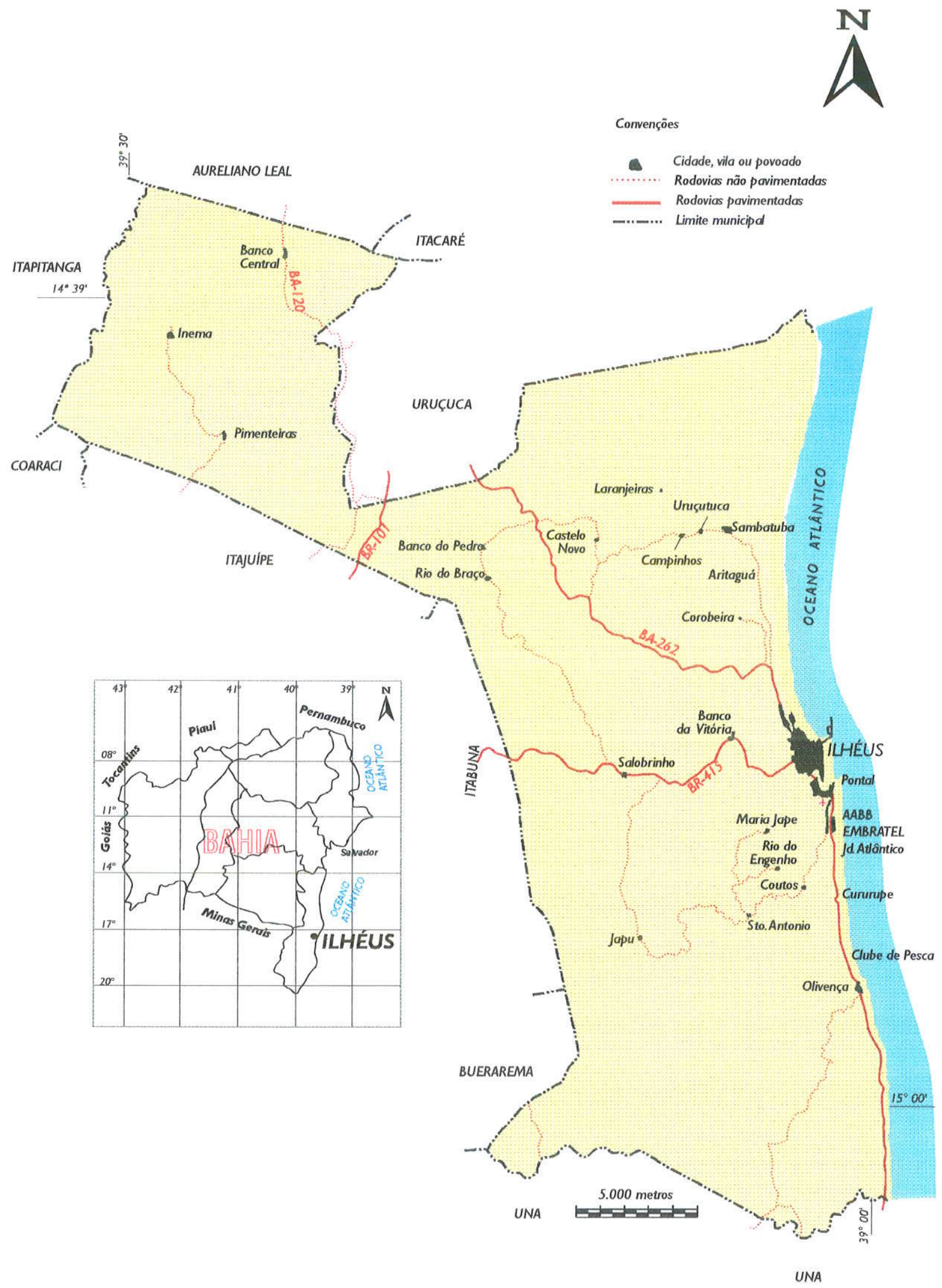

Figura 3.7 Localização geral do município de Ilhéus/BA. 
A principal atividade econômica é a exploração cacaueira. Atualmente a produção encontra-se bastante comprometida pela presença de pragas (vassoura de bruxa) que afetaram de forma negativa a economia municipal.

O fortalecimento do turismo pode vir a ser um fator importante e decisivo no soerguimento da economia regional. No entanto, o desenvolvimento deste setor da economia está vinculado, diretamente, à melhoria da qualidade de vida na cidade de llhéus e, para atingir este objetivo, é fundamental o investimento no setor de saneamento básico. Para tal, no início do ano de 1997, a CONDER - Companhia de Desenvolvimento da Região Metropolitana de Salvador, dentro do Programa de Desenvolvimento Turístico do Nordeste promoveu um processo licitatório para a realização do Plano Diretor de Resíduos Sólidos do Município de llhéus, fazendo parte deste macro - estudo, a seleção de áreas para a implantação do aterro sanitário.

A implementação deste programa está diretamente correlacionado a situação ambiental atual da área de disposição de resíduos, que é na forma de lixão. A área está inserida em cotas topográficas baixas (entre 3 a 4 metros acima do nível do mar) da planície aluvionar do Rio Cururupe. $\mathrm{O}$ aqüífero é de raso a aflorante, influenciado pelas oscilações da maré. O rio que drena a área do aterro deságua na praia homônima, importante ponto turístico do município (fotos 17 e 18)
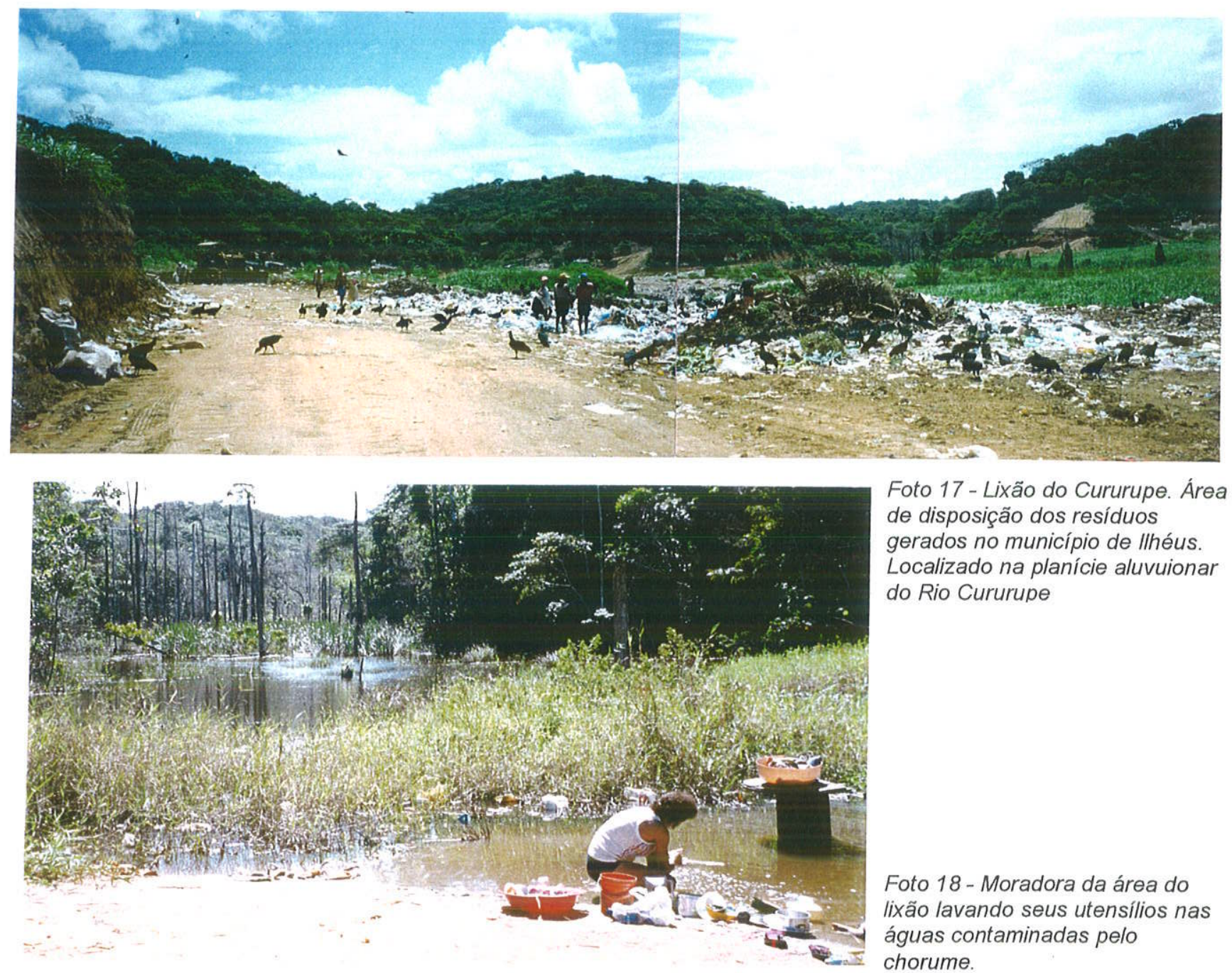

Foto 17 - Lixão do Cururupe. Área de disposição dos resíduos gerados no município de llhéus. Localizado na planície aluvuionar do Rio Cururupe 


\subsubsection{Geologia}

O município de llhéus está assentado sobre duas unidades geológicas principais: rochas pré - cambrianas e as coberturas sedimentares (figura 3.8).

A unidade pré-cambriana congrega rochas arqueanas denominadas Dominio Coaraciltabuna (subdividida em Complexo Ibicaraí-Buerarema e Complexo São José), Domínio IlhéusOlivença (Complexo llhéus); e pela Suíte Intrusiva Itabuna. (CPRM 1993).

O Complexo ibicaraí-Buerarema é representado por um conjunto de rochas gnáissicas granulitizadas, plutônicas e de composição tonalítica, contendo corpos descontínuos e irregulares de metagabros, metanoritos e metamonzodioritos. Engloba também uma faixa de biotita-gnaisses, hornblenda gnaisses, granitos e granodioritos gnáissicos, denominada de Unidade Rio Japu. $O$ Complexo São José engloba rochas magmáticas, granulitizadas, pertencentes às séries toleítica e calcialcalina, sendo representado por metatonalitos, metanoritos, metadioritos, metabasalto e leptitos. Essas rochas estão estruturadas segundo a direção NNE-SSW, através de bandas alternadas em meso e macroescala, constituindo cristas e vales bem delineados.

O Domínio Ithéus-Olivença (Complexo Ithéus) é composto por uma seqüência de rochas granuliticas bandadas, provavelmente vulcanogênicas, de composição dacítica a basáltica, às quais associam-se ocorrências isoladas de rochas plutonotonaliticas granulitizadas.

A Suíte Intrusiva Itabuna, com rochas alcalinas, é representada essencialmente por sienitos, nefelina-sienitos, monzodioritos, leucogabros, dioritos e noritos.

As coberturas sedimentares compreendem a seqüência jurocretácica da Bacia Sedimentar do Rio Almada, os sedimentos terciários da Formação Barreiras e os sedimentos quaternários (CPRM 1993).

A Bacia Sedimentar do Rio Almada, é composta, da base em direção ao topo, pelas formações Sergi, Itaparica, Candeias, Grupo lihas e Formação Urucutuca. As Formações Sergi, Itaparica e Candeias são compostas por arenitos, siltitos e folhelhos micáceos e carbonosos, com intercalações de calcários. O Grupo llhas é constituído por conglomerados. A Formação Urucutuca encerra a seqüência mesozóica, composta por uma alternância de folhelhos, calcários, siltitos, arenitos e conglomerados.

A Formação Barreiras foi resposta ao progressivo basculamento da região Nordeste do Brasil durante o Terciário, com subsidência das áreas costeiras e soerguimento das áreas continentais adjacentes, propiciando a sedimentação de um complexo de leques aluviais, amalgamados, associados distalmente a sistemas fluviais entrelaçados. Ocorre em extensos tabuleiros, dispostos em patamares ligeiramente inclinados em direção à costa e assentados discordantemente sobre os sedimentos juro-cretácicos da bacia do Rio Almada e rochas granuliticas pré-cambrianas. Sua espessura varia em função da intensidade de erosão de seu topo e do relevo das rochas pré-terciárias, porém não ultrapassa $60-70$ metros. É constituida por arenitos brancos, cinza e avermelhados, grosseiros e conglomeráticos, pobremente selecionados, 
com quartzo e cristais de feldspatos preservados, interestratificados com argilas variegadas de natureza caulítica. São sedimentos continentais, apresentando-se geralmente com estratificação pouco distinta e subhorizontal, e às vezes perturbadas por estratificações cruzadas (DNPM 1979).

Os depósitos quaternários incluem os Terraços Marinhos; os Depósitos Fluviolagunares; e os Depósitos Aluvionares. Os Terraços Marinhos são caracterizados por uma sucessão de cristas arenosas (cordões litorâneos) alinhados paralelamente a atual linha de costa, constituídas por areias de granulação fina a média, localmente grosseira. Os depósitos Fluvilagunares são constituídos por áreas de mangue, caracterizados pela ocorrencia de detritos vegetais, argilas orgânicas intercaladas em camadas arenosas. Pântanos, constituídos essencialmente por turfa, desenvolvem-se nas zonas intercordões e vales adjacentes aos terraços fluviais. Os Depósitos Aluvionares incluem sedimentos arenosos, argilosos, siltosos e cascalhos em proporções variadas estão inseridos nas planícies aluviais de inundação, diques marginais, canais abandonados e entrelaçados.

\section{Aspectos estruturais}

O arcabouço estrutural é caracterizado pela grande linearidade dos traços das foliações regionais dos gnaisses de alto grau metamóntico, preferencialmente de dreção N-S e em geral verticalizadas, e por dois sistemas de falhamentos principais, sendo um de direção NE-SW e o outro NNE-SSW (CPRM 1993).

Os sistemas de deformação rúptil-dúctil e rúptil, que apresentam as principais estruturas de interesse para o proposto estudo, consistem em dois sistemas de falhamentos principais, um na direção $\mathrm{N} 40^{\circ}$ E e outro NNE-SSW, além de fraturas secundárias de direção NW-SE.

Dentre os eventos tectônicos verificados na área, destacam-se três sistemas de falhas principais, geradas possivelmente a partir de reativações de zonas de cisalhamento dúctil pretéritas, ocorridas durante o Neoproterozóico.

O sistema de falhas mais antigo da tectônica rúptil, apresenta direção NNE e tem como principal representante a falha de Uruçuca, com movimento transcorrente dextral.

O segundo grande sistema é definido pelas falhas diagonais de direção NE-SW referidas como zona de cisalhamento de Itabuna (DNPM, 1979). Esta zona encontra-se limitada por duas grandes falhas de direção N4OE (falhas de Buerarema e do Rio do Braço), constituindo uma das mais importantes feições estruturais da área.

O terceiro sistema ocorreu no Cretáceo Inferior, com a reativação dos falhamentos anteriores, produzindo uma estrutura do tipo rifte, onde se depositaram os sedimentos da bacia do Rio Almada. 


\subsubsection{Geomorfologia}

Segundo Nunes et al. (1981), no municipio de Ilhéus ocorrem quatro domínios morfoestruturais: Depósitos Sedimentares; Depressões Interplanálticas; Planaltos Inumados; e Planaltos Cristatinos (figura 3.9).

O Domínio dos Depósitos Sedimentares inclui os sedimentos cenozóicos e mesozóicos da unidade Planícies Marinhas e Fluviomarinhas. As Planícies Marinhas comportam as praias e terraços marinhos que correspondem à faixa arenosa com inclinação suave em direção ao mar, estando sujeitas à ação das ondas e das marés que modificam sua topografia. Os terraços marinhos limitam internamente a linha de praias e são caracterizados por cordões litorâneos que apresentam expressão marcante ao longo de uma estreita faixa que ocupa quase todo o litoral, condicionando o baixo do Rio Almada, ao norte da Cidade de lihéus, paralelo a costa. As Planícies Fluviomarinhas ocorrem junto à foz dos rios Cachoeira e Almada, nas áreas de mangue que são caracterizadas por terrenos planos, alagadiços, sujeitos à ação fluvial e ao refluxo das marés, comportando canais de marés e vegetação própria, adaptada às condições hidrológicas. Incluem as falésias, que são costas de abrasão, esculpidas através da ação mecânica das ondas do mar que provocam o recuo dos tabuleiros através do solapamento de suas bases.

O Domínio Depressões Interplanálticas é representado pela unidade Depressão de Itabuna-ltapetinga, que ocupa as áreas constiłuidas pelos diques máficos pós-tectónicos proterozóicos. Caracteriza-se por um modelado de aplainamento integrado por um pediplano já parcialmente dissecado, onde a drenagem faz incisões fracas, configurando lombadas. Os interflúvios geralmente são dissecados, resultando em colinas e morros convexo-côncavos. $O$ escoamento superficial é difuso e concentrado originando sulcos e ravinas, formando às vezes alvéolos de cabeceira. Os vales apresentam fundos planos colmatados.

O Domínio dos Planaltos Inumados é representado pela unidade geomorfológica dos Tabuleiros Costeiros desenvolvidos sobre depósitos da Formação Barreiras. Compreende relevo tabuliforme, com altitude máxima de 185 metros e que se encontra submetido a dissecação intensa e uniforme.

O Domínio Planaltos Cristalinos é representado pela unidade dos Tabuleiros PréLitorâneos desenvolvido sobre rochas pré-cambrianas que recobre grande porção do município. É caracterizado por apresentar relevo bastante uniforme, tendo a erosão dissecado intensa e indiferentemente as rochas pré cambrianas alteradas. Os interflúvios geralmente correspondem a ousteiros e morros de vertentes convexas e convexo-côncavas, que em certos trechos compóe uma paisagem de mares de morros. 


\subsubsection{Cobertura superficial}

Os diversos tipos de solos existentes na região são decorrentes da associação litológica e da atuação do clima tropical super-úmido a úmido (Nunes et al., 1981).

Os solos incidentes na Planície Costeira são desenvolvidos sobre sedimentos fluviomarinhos, eólicos e palúdicos constituindo as areias quartzosas hidromórficas. Os solos indiscriminados de mangue são encontrados preferencialmente junto a desembocaduras dos rios Cachoeira e Almada, influenciados diretamente pelas águas do mar, constituidos por uma associação de Solonchaks e solos Glei Tiomórficos, apresentando horizontes gleizados e com elevados teores de sais (solos halomórficos) e compostos de enxofre. Há ocorrência de muita matéria orgânica proveniente das espécies que compõe a vegetação típica de mangue, fornecendo alimentos a uma grande quantidade de crustáceos, e portanto, tratam-se de áreas importantes para preservação ambiental. Os solos Glei pouco Húmico, ocorrem em relevo plano associado a solos orgânicos, com textura argilosa a muito argilosa e coloração escura e, às vezes, com mosqueamentos amarelados e são pouco prołundos e capacidade de drenagem baixa, propiciando encharcamentos.

Os solos incidentes nos demais domínios geomorfológicos são constituidos essencialmente por latossolos amarelos; podzólicos amarelos/vermelho-amarelos a vermelhoescuros, distróficos e eutróficos, álicos, una a una-álicos, de espessura muito variável.

Sobre a Formação Barreiras os solos superficiais são inconsolidados, com espessura média de 4 a 6 metros, composto por argilas caoliníticas cobertas por colúvios arenosos com seixos e placas de canga ferruginosas retrabahadas. Encontra-se submetido a processo de podzolidação, o que provoca o aparecimento de solos arenosos na superfície.

\subsubsection{Hidrologia}

Os cursos d'água que interceptam a área geográfica do município de llthéus, são abrangidos principalmente pela Bacia Hidrográfica da Região Leste (enquadrada pelo Decreto Estadual $N^{0} 28.687$ de 11/02/1982). O município é interceptado por quatro drenagens maiores: Rio Almada - a Norte; Rio Cachoeira - no Centro; rios Santana e Acuípe - a Sul. Deságuam nas proximidades da cidade de lihéus, com exceção do Rio Acuípe, no extremo Sul. Ocorrem pequenas bacias que drenam diretamente para o mar, denominadas de Bacias Costeiras, destacando-se as dos rios Cururupe ou Cururutinga, Aguipe e Maruim.

Os rios são perenes e deságuam nas proximidades da Cidade de lihéus, onde originam estuários influenciados pela ação do mar, propiciando a vegetação de mangue (foto 16 - pag. 54).

O uso indiscriminado de fertilizantes e pesticidas utilizados na região para o combate a pragas e doenças do cacau, e a ausência de serviços de infra-estrutura urbana, principalmente no tocante aos efluentes e residuos sanitários e industriais, contribuem significativamente na 
deterioração da qualidade das águas dos principais rios que interceptam o município de lthéus.

O reflexo direto da deterioração dos cursos d'água é o acréscimo da geração das baronesas (Eichornia crassipes), que na época de grandes vazões acumulam-se nas praias de Ilhéus.

Os aqüiferos incidentes nas rochas pré-cambrianas apresentam potencialidade variando de fraca a média, que é condicionada pelas estruturas geológicas. Os aqüíferos dos sedimentos terciários se comportam de formas distintas. Os incidentes na Formação Barreiras se apresentam como um sistema de aqǘffero livre, embora as intercalações de horizontes mais argilosos entre seqüencias arenosas, conduzam à formação de aqüiferos confinados e semi-confinados. Possui o maior potencial hídrico subterrâneo do município.

\section{2 .1 .5 Clima}

O municipio encontramse inserido na faixa litorânea pluviosa, a qual mostra índices pluviométricos superiores a $1.250 \mathrm{~mm}$ anuais, diminuindo gradativamente para o interior. Na. Cidade de llhéus, as precipitações são superiores a $1.900 \mathrm{~mm}$ anuais. A maior incidência de chuvas ocorre no periodo de abril a agosio, o que caracteriza um regime de chuvas do tipo mediterâneo. A temperatura média anual também decresce do litoral para o interior, sendo julho e agosto os meses mais frios, enquanto janeiro e fevereiro são os mais quentes (Nunes et al., 1981).

De acordo com a classificação de Köppen, a área apresenta dois tipos de clima, um na faixa costeira (Af) e outro na zona mais interna (Am). O clima Af́ é o da "Mata Atlântica", que se caracteriza por ser superúmido, com precipitação do mês seco superior a $60 \mathrm{~mm}$ e temperatura média do mês mais frio superior a $18^{\circ} \mathrm{C}$. O clima Am é úmido, com precipitação do mês mais seco inferior a $60 \mathrm{~mm}$ e temperatura média do mês mais frio superior a $18^{\circ} \mathrm{C}$.

\section{2 .1 .6 Cobertura vegetal}

O contato com o oceano, a existência de inúmeros corpos de água em função da grande pluviosidade e principalmente os fatores ambientais gerados pelas condiçóes geomorfológicas, topográficas e pedológicas, originam uma diversidade de associações vegetais típicas da mata pluvial atlântica, que abriga um sistema ecológico de grande valor na região, do ponto de vista genético, econômico e científico.

O cultivo de cacau foi, e ainda é, responsável pela preservação de expressivas manchas de Mata Atlântica, visto que seu desenvolvimento é favorecido pelas condições climáticas e pedológicas presentes na zona de floresta ombrófila. 


\subsubsection{Processo de seleção de sítios para o aterro sanitário}

\subsubsection{Método utilizado para a seleção de sítios}

A pesquisa de sítios visando a implantação do aterro sanitário do município de llhéus envolveu diversos procedimentos metodológicos, desenvolvidos em diferentes graus e níveis de abrangência, através de uma equipe multidisciplinar.

A etapa inicial da pesquisa buscou identificar o zoneamento ambiental do município, que teve como principal objetivo o entendimento e conseqüente delimitação das zonas passíveis para a pesquisa de sítios.

Foi realizado um levantamento de dados junto aos órgãos e entidades municipais, estaduais e federais, que compreenderam: a Prefeitura Municipal de lthéus, Centro de Recursos Ambientais/CRA, Empresa Baiana de Águas e Saneamento/EMBASA, Comissão Executiva do Plano da Lavoura Cacaueira /CEPLAC e o Instituto Brasileiro do Meio Ambiente e Recursos Renováveis /BAMA. As Organizações Não Governamentais - ONG's também foram consultadas com o propósito de engajá-las no processo de prospecção e seleção do aterro sanitário.

Como produto foi elaborado um mapa na escala 1: 100.000 que contemplou o zoneamento ambiental do município, denominado de Macro-regióes Restritivas. Estas regióes são denominadas como "Áreas Sensíveis", de acordo com a NBR 13.897, 1997.

As macro-áreas (ou áreas sensiveis) consideradas como incompativeis com o aterro foram: as bacias hidrográficas voltadas ao abastecimento público de água (mananciais), áreas verdes legisladas através de leis e/ou decretos, as áreas de Preservação Permanente - compostas por manguezais, restingas e Mata Atlântica (de acordo com a Lei Federal $N^{\circ} 4771$ ), a orla marítima, áreas voltadas ao lazer, a mancha urbana e o vetor de expansão urbana.

As áreas de mananciais compreendem as bacias hidrográficas dos rios Iguape e Santana, responsável respectivamente pelo abastecimento da porção norte e sul do município (figura 3.10 pag. 67).

Como áreas verdes legisladas, foram identificadas a Área de Proteção Ambiental (APA) da Lagoa Encantada e o Parque Municipal da Boa Esperança, que apresentam uma significativa cobertura de mata, composta por remanescentes da Mata Atlântica e exemplares endêmicos da fauna e flora local e regional (figura 3.10 - pag. 67).

Os manguezais que ocupam principalmente as desembocaduras dos rios Cachoeira, Santana e Almada. A orla marítima que limita o município em toda a sua porção oriental.

O vetor de expansão urbana que se concentra ao longo da orla marítima e adjacências, principalmente entre o Distrito de Olivença - a sul; e o Distrito Industrial a norte, como também, a faixa que acompanha as estradas que interligam os municipios de théus e labuna (BR-415), no trecho entre a cidade de llhéus e Buerarema (BR-251), e a interligação Ihéus-ltacaré. 
Em seguida foi delimitada a área de abrangência da pesquisa. Foram adotados os raios de 10 e $20 \mathrm{~km}$ a partir do centro geométrico gerador de residuos (considerado a Catedral da cidade). O primeiro, serviu como referência do limite desejável, no entanto, a incidência de áreas sujeitas a inundação e de Preservação Permanente (mangues, pântanos e restingas) próximas ao centro da cidade restringiram consideravelmente o espaço disponivel para pesquisa. O segundo, foi estabelecido como limite máximo para a pesquisa dos sítios, conforme critério de IPT-CEMPRE (1995). Esta publicação considera que distâncias superiores a $20 \mathrm{~km}$ resultam em custos de transporte muito elevados, onerando sobremaneira os custos operacionais do serviço de coleta.

A associação entre a delimitação das macro - áreas com restrições ambientais e o raio máximo de abrangência do estudo resultou na delimitação de áreas de interesse para prospecção de sitios (figura 3.10 - pag. 67).

\section{Critérios do meio físico}

A partir da delimiłação das áreas que não apresentavam restrições ambientais, foi iniciada a análise dos aspectos físicos incidentes nas diversas áreas remanescentes.

Nestas áreas foi realizada interpretação de fotografias aéreas na escala 1:25.000 (1964) e análise de mapas topográficos, na escala 1:100.000 (escala disponivel). O principal objetivo foi identificar estruturas geológicas, a morfologia das vertentes, o sistema de drenagem, traçar divisores de água, avaliar as dimensões dos sítios e as condições de acesso. Também envolveu a análise das áreas indicadas pela Prefeitura Municipal, pelo CRA/Centro Recursos Ambientais, as áreas degradadas pela atividade minerária e a área atual de disposição dos resíduos do município. Após esta etapa algumas regiões tornaram-se mais favoráveis para a prospecção de sítios. Dentre estas regiões foram demarcados nove sitios para a realização de investigações mais detalhadas através de trabalhos de campo.

Os sitios foram agrupados conforme suas localizações geográficas no município, conforme os setores Sul, Oeste/Sudoeste e Norte/Noroeste. O principal objetivo desta compartimentação foi direcionar os trabahos de campo.

Com o objetivo de planejar os trabalhos de campo as áreas foram agrupadas de acordo com suas localizações geográficas no município, o qual foi compartimentado em setores: Sul, Oeste/Sudoeste e Norte/Nordeste.

Os critérios físicos utilizados para as investigações de campo foram também fundamentados na NBR 13.896, 1997.

A situação fisiográfica ideal, que satisfaz os requisitos acima, é a de anfiteatros amplos (com baixa a média declividade), em cabeceiras de drenagem, desenvolvidas sobre rochas pouco permeáveis (com baixa porosidade primária e/ou secundária) e com espessas coberturas de material rico em argilo-minerais. Portanto, a prospeção de locais favoráveis para deposição de 
resíduos sólidos (neste caso, domésticos), deve envolver a análise geomorfológica e hidrográfica da região, procurando áreas de divisores de água em cotas altas, seguida pela investigação geológica do substrato rochoso e do seu material de cobertura. O material rochoso deve ser caracterizado quanto à sua natureza (identificação litológica) e, principalmente, com relação à sua porosidade e permeabilidade, o que requer a caracterização estrutural da rocha (identificação e mapeamento de descontinuidades, como porosidade primária, planos de estratificação, fraturas e falhas).

Aliado aos aspecios geomorfológicos e geológicos acima, deve-se observar a posição do nivel da água, o qual, em situação favorável, não pode interceptar as vertentes do anfiteatro.

A primeira fase de seleção se concentrou no setor Sul do llhéus, abrangendo as bacias hidrográficas costeiras e a bacia do Rio Cururupe. A pesquisa foi iniciada neste setor, pela existência de acesso. Embora não pavimentado, a possibilidade da realizaçäo de melhorias na estrada foi inicialmente considerada, pois trata-se de um acesso intermunicipal (Ithéus-Buerarema). Nesta fase foram identificados os sítios Embasa (1), Areal (2), Cururupe (3), Fazenda Omologi (4) e Fazenda Arabela (5) (figura 3.10).

A segunda fase de prospecção se concentrou no setor Oeste/Sudoeste de theus, abrangendo a bacia do Rio Cachoeira. A interligação entre este setor e a mancha urbana de lihéus é através da rodovia BR 415 (interligação lihéus - ltabuna) e BR 101, que representam as melhores condições de acesso do município. Foram identificados os sitios Maria Jape I (6) e Maria Jape II (7) (figura 3.10 ).

A terceira fase se concentrou no setor Norte e Noroeste de llhéus, na bacia hidrográfica do Rio Almada. Este setor foi pesquisado devido a presença de acesso pavimentado da BA - 262 (Ilhéus - Uruçuca) Foram identificados os sítios Carobeira (8) e ltariri (9) (figura 3.10).

\subsubsection{Principais características dos setores analisados}

As principais caracteristicas geológicas, geomorfológicas e hidrográficas dos sítios analisados encontram-se descritas a seguir. Além destas características, a tabela 3.3 - pag. 85, relaciona para cada sítio analisado, as distâncias do núcleo urbano, do centro geométrico gerador de resíduos, da orla marítima e as condições de acesso e vida útil estimada. 


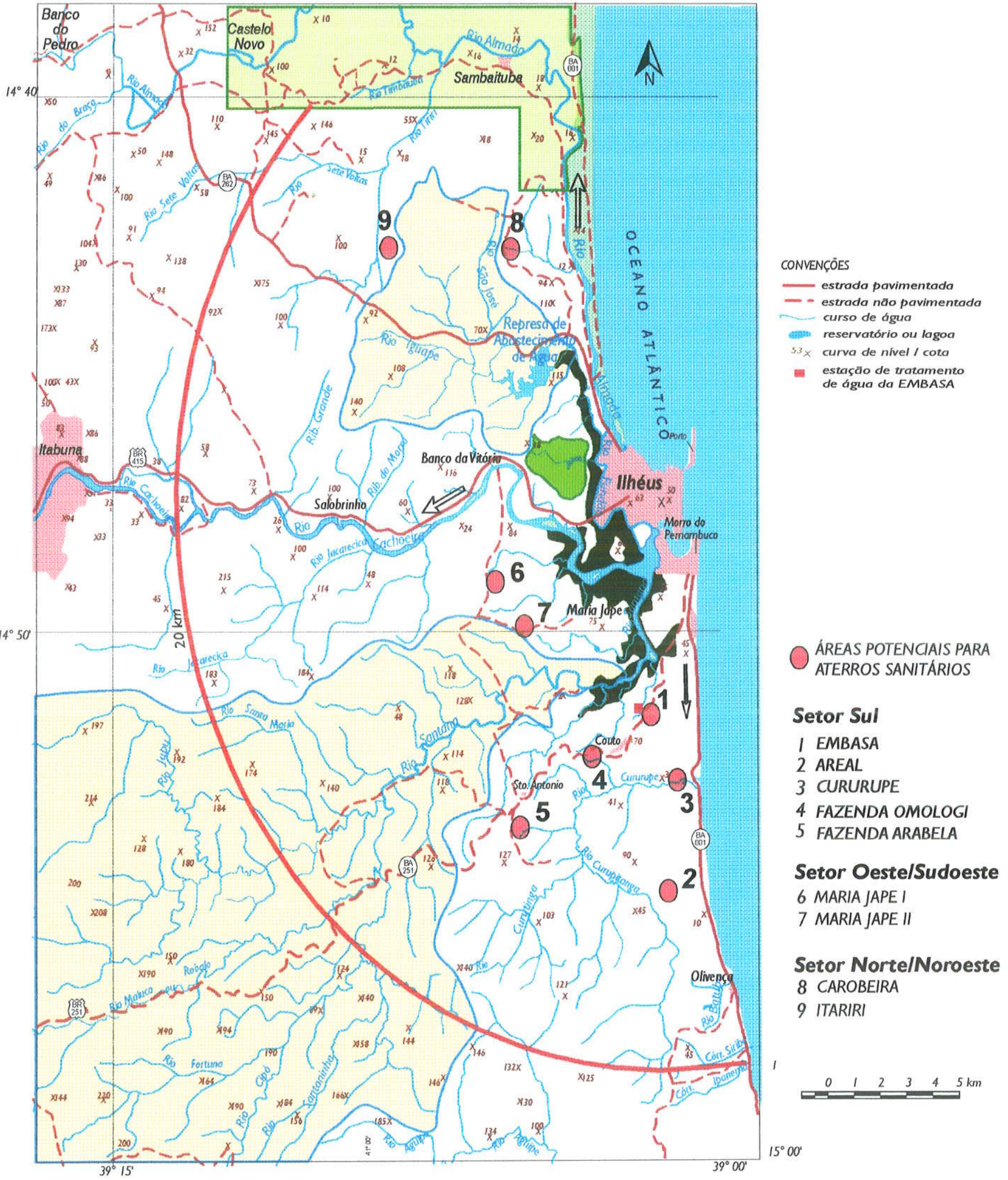

ÁREAS COM RESTRIÇÖES PARA ATERROS SANITÁRIOS

Área de Proteção Ambiental da Lagoa Encantada

Parque Municipal da Boa Esperança

Áreas de preservação de mananciais

Mangue

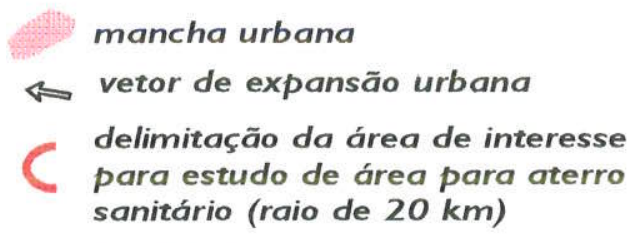

\section{Figura 3.10 - Zoneamento ambiental do município de Illhéus visando a implantação de aterros sanitários (adaptado de Conder/Equipe Umah, 1997)}




\section{SETOR SUL DE ILHÉUS}

Os sítios analisados no Setor Sul estão inseridos nas bacias hidrográficas costeiras e na bacia do Rio Cururupe (foto 19).

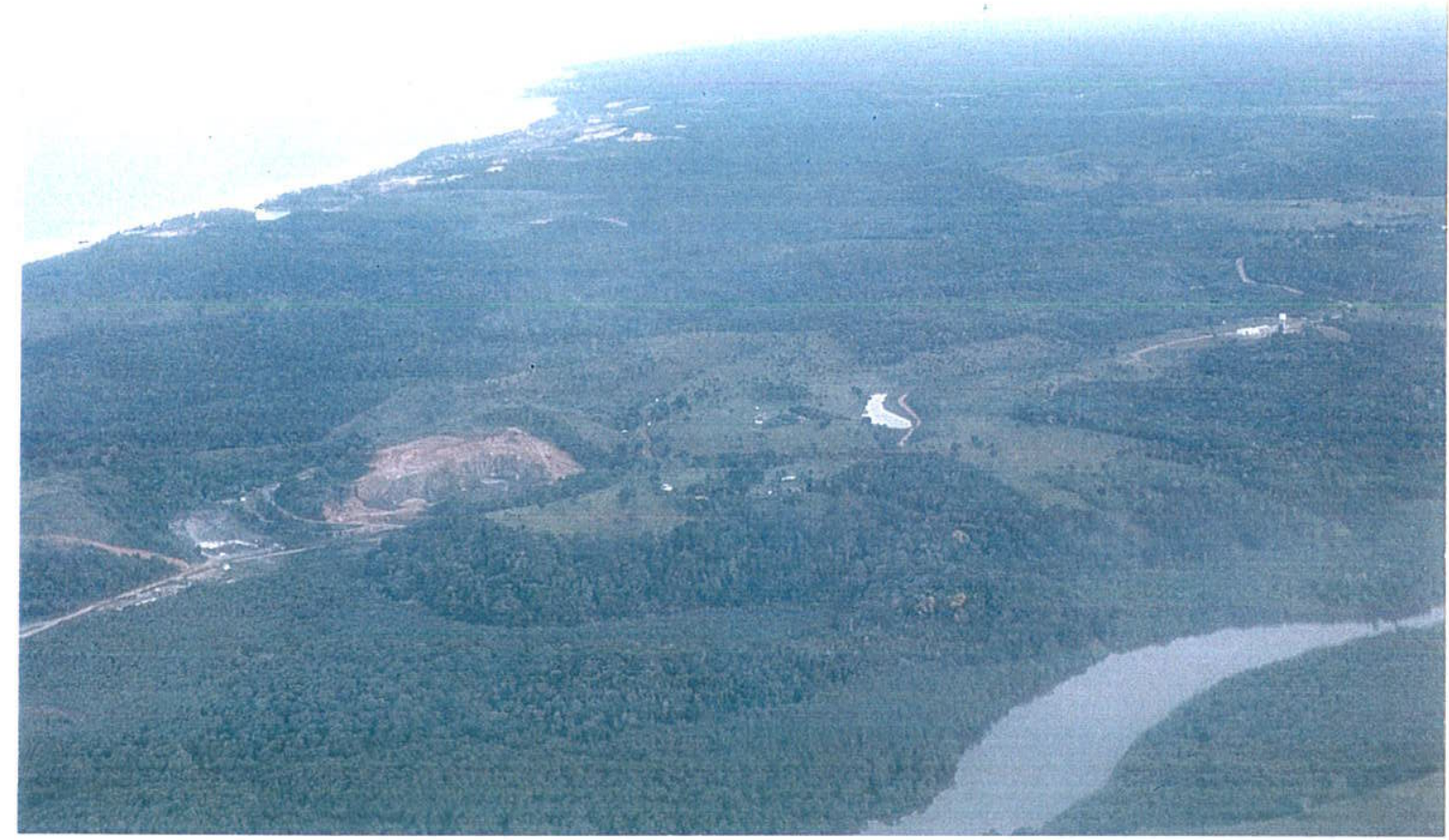

Foto 19 - Vista aérea do Setor Sul de Ilhéus exibindo as áreas drenadas pelas bacias costeiras e a bacia do Rio Cururupe. No centro, estrada de acesso à Buerarema. A esquerda, pedreira em granulitos básicos do embasamento.

\section{BACIAS COSTEIRAS}

As bacias costeiras são formadas por pequenas bacias que drenam diretamente para o mar, e geralmente, estão muito próximas à linha de costa com cotas muito rasas. $\mathrm{Na}$ área de estudo ocorrem duas bacias costeiras isoladas, denominadas de Bacia Costeira Norte e Bacia Costeira Sul. A distância máxima dos seus divisores até a orla marítima é de 2,5 km.

Na Bacia Costeira Norte, na transição entre a planície costeira e os morros do interior, insere-se o sítio EMBASA (Sítio 1).

$\mathrm{Na}$ Bacia Costeira Sul foram visitadas as cavas de exploração de areia existentes na extremidade Sul da área. Entre as inúmeras cavas, foi verificada a existência de um sítio que teria capacidade de receber maior volume de resíduos, denominado de AREAL (Sítio 2).

\section{EMBASA (Sítio 1)}

Localiza-se em frente à Estação de Tratamento de Água da EMBASA (Sistema Santana), no lado esquerdo da estrada BA-251 no sentido Buerarema. 


\section{Geomorfologia}

A área localiza-se no flanco leste do divisor de águas entre a bacia do Rio Santana, a Oeste-Noroeste e uma pequena bacia de drenagem para o mar. Apresenta morfologia de topos aplainados, com cotas máximas em torno de $70 \mathrm{~m}$, posicionando-se na transição entre o domínio de morros do interior e a planície costeira. Caracteriza-se por anfiteatros de cabeceiras de drenagens com declividades entre 150 a 30 o. O maior deles forma uma área semicircular de cerca de $120 \mathrm{~m}$ de diâmetro (foto 20). O desnivel entre os topos aplainados e os fundos de vales, ao longo dos anfiteatros é de cerca de 20 a $40 \mathrm{~m}$.

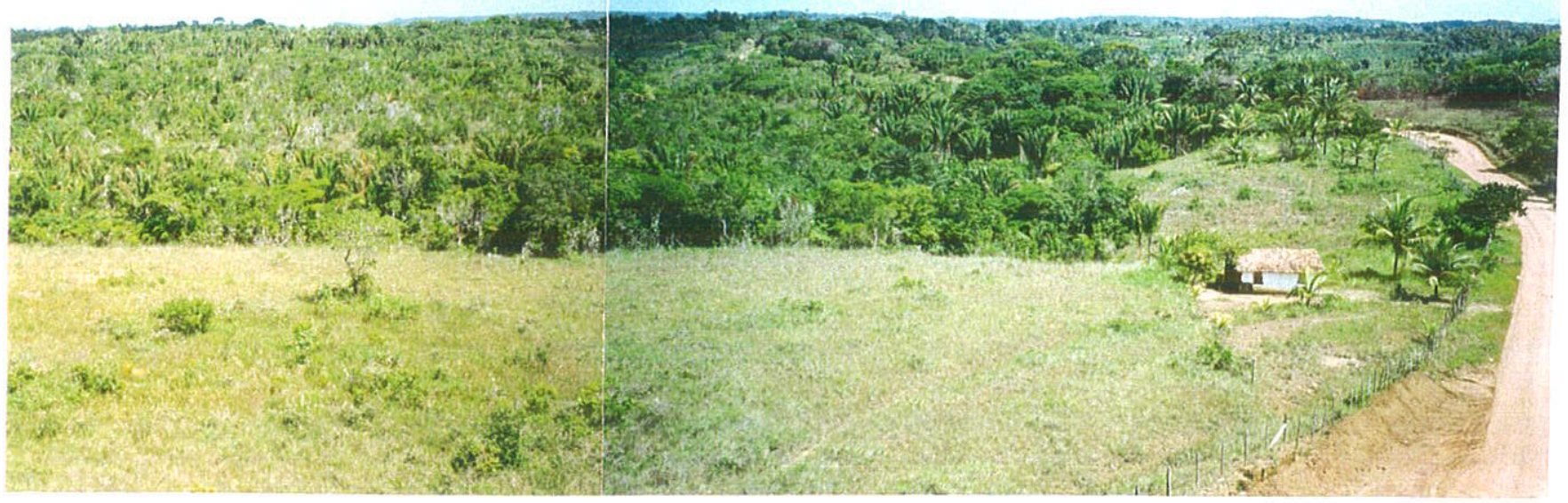

Foto 20 - Vista aérea do sítio Embasa. Anfiteatro de cabeceira de drenagem ocupado pela mancha de vegetação no centro da foto. Morfologia de morros com topos aplainados. A direta estrada não pavimentada sentido Buerarema.

\section{Geologia}

Estende-se sobre os produtos de alteração de rochas metabásicas de composição basáltica a andesítica, as quais representam um dos tipos litológicos característicos do Complexo Ilhéus. Ao longo da área, esta rocha de coloração escura pode ser observada localmente em blocos e calhaus imersos no material intempérico. Devido à proximidade entre este local e a pedreira de exploração de brita, instalada a beira da estrada de acesso a área, infere-se que o substrato rochoso desta área seja o mesmo da pedreira, pois a cobertura de solo é típica destas rochas básicas. Nesta pedreira ocorre o conjunto de rochas metabásicas bandadas e foliadas, onde se alternam bandas de espessura decimétrica a métrica, com diferentes texturas, marcadas pela variação do tamanho dos cristais e pela coloração de cinza escuro a negro.

Estruturalmente as metabásicas caracterizam-se pelo bandamento composicional coincidente à foliação metamórfica, com direção geral N25-30E e caimento de 45-50SE. Ocorrem dois conjuntos de fraturas, com atitudes gerais de N33-40W, 70-80SW e N50-57E 50-60NW. O primeiro representa fraturas decamétricas com espaçamento métrico, cortando toda área exposta da pedreira. O segundo é menos freqüente, constituindo fraturas métricas. Fraturas sub-horizontais são pouco freqüentes e de pequena extensão. Considera-se que estas características estruturais 
são semethantes à da área analisada para o aterro, devido ao comportamento regional destas feições.

\section{Manto de intemperismo}

A cobertura superficial é representada por um solo de coloração marrom escuro avermethado de composição argilosa a siltosa. A espessura desta cobertura pedológica varia entre alguns metros a uma dezena de metros, inferida pela observação de cortes expostos em locais nas proximidades da área. Fragmentos de concreções ferruginosas arenosas sobre o solo testemunham a cobertura do Grupo Barreiras, atualmente pouco expressiva. Escavaçóes realizadas nas obras da ETA, em implantação pela EMBASA, confirmaram espessura da cobertura argilosa de, no mínimo, $4 \mathrm{~m}$ no topo aplainado.

\section{Hidrologia}

Representa uma bacia que drena diretamente para o mar, distante de aproximadamente $2,5 \mathrm{~km}$ em linha reta da linha de costa. As drenagens associadas aos anfiteatros seguem para cotas baixas da planicie costeira. No fundo destes vales, o aqüífero aflora em épocas chuvosas, formando pequenos córregos e zonas encharcadas.

\section{Análise da aptidão para implantação de aterro}

Como aspectos favoráveis destacam-se: inserção em anfiteatros em cota topográfica relativamente alta, baixa permeabilidade do maciço devido ao baixo grau de interconexão entre as fraturas, existência de cobertura de solo argiloso (observar que a confirmação da sua continuidade só é possível através de sondagens); facilidades de acesso e distância de $10 \mathrm{~km}$ do centro da Cidade de lithéus. Os aspectos desfavoráveis são: pequena vida útil, impacto visual para os usuários estrada BA-251, necessidade de melhorias (alteamento da pista e obras de drenagem) na estrada de acesso numa extensão aproximada de $2,5 \mathrm{~km}$.

\section{AREAL (Sitio 2)}

Está inserido na zona de mineração de areia do município, concentrada na região entre a foz do Rio Cururupe e o Distrito de Olivença. O acesso principal é dado pela Rodovia BA-001 (Pontal - Olivença). 


\section{Geomorfologia}

As cavas de areia estão inseridas na transição entre a atual planície de maré e colinas suaves, com cotas máximas em torno de 20 a 50 m. Estas áreas são caracterizadas pela baixa densidade da rede de drenagem, solo pouco desenvolvido e manchas de vegetação de restinga. Entre as colinas ocorrem vales com amplas planícies e drenagem com canais entrelaçados e pequenos lagos, com influência da maré.

\section{Geologia}

Estes depósitos de areias pouco consolidadas representam áreas de retrabalhamento pleistocênico dos depósitos terciários do Grupo Barreiras, em ambiente de planícies flúviomarinhas, com planícies de maré e restingas. São compostos por areias de granulação média a grossa, predominantemente mal selecionadas, estratificação plano paralela em camadas de espessura decimétrica a métrica, e estratos cruzados de variada geometria e com dimensões de até vários metros. Estes estratos cruzados são atribuídos ao retrabalhamento de planícies de maré em ambiente eólico. Localmente ocorrem intercalações de areias escuras e camadas de argilitos e siltitos, pouco expressivas em relação às areias. A espessura destes pacotes arenosos varia entre alguns metros a 20 metros, como pode ser observado nas cavas de extração de areia. As areias são compostas essencialmente por grãos de quartzo e feldspato cinza claro, apresentando baixo grau de compactação, o que facilita sua extração, conforme pode ser observado nas várias cavas existentes na área (foto 21).

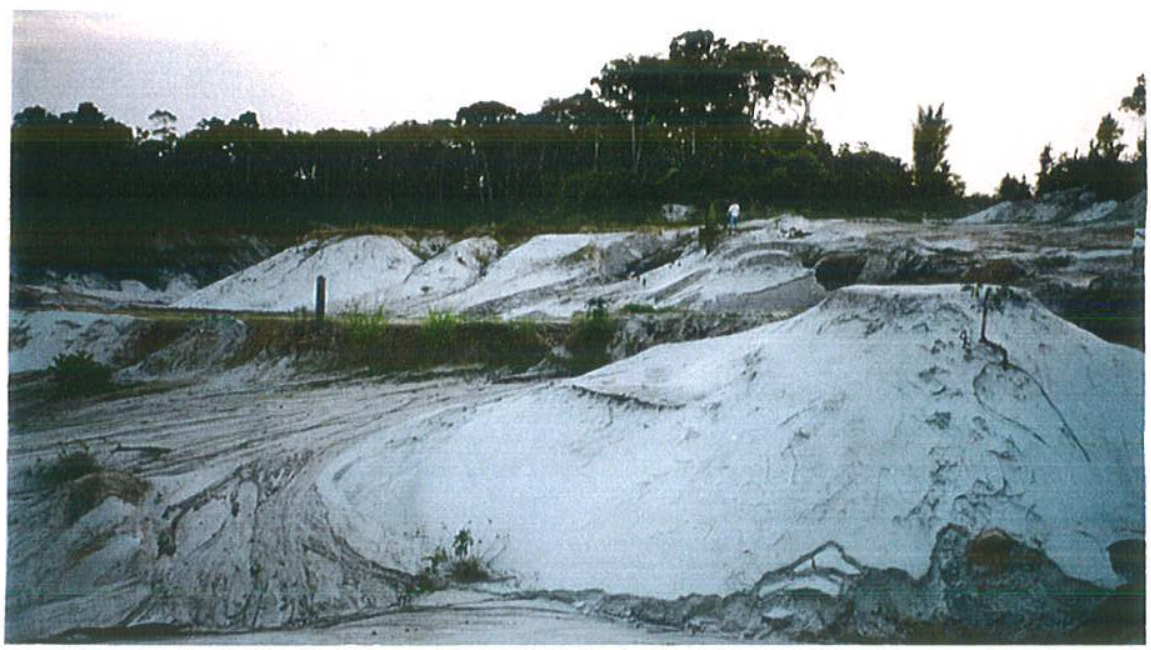

Foto 21 - Areal. Cava de extração de areia. Ocorrência de areias pouco consolidadas ao longo dos taludes escavados.

\section{Hidrologia}

Está inserida numa bacia que drena diretamente para a linha de costa. Devido a alta permeabilidade destas areias inconsolidadas, o desenvolvimento de drenagem superficial é 
incipiente. Nos fundos de vales é freqüente o afloramento do nível de água, condicionando zonas encharcadas e ambientes lacustres.

\section{Análise da aptidão para implantação de aterro}

Como aspectos favoráveis destacam-se: a alta capacidade volumétrica, excelente disponibilidade de áreas de empréstimo e a própria recuperação da área degradada. Como desfavoráveis: altíssima permeabilidade e baixa compacidade do substrato, baixas cotas em relação ao nivel do mar e afloramento do nível de água na base das escavações de areia e nos vales naturais associados.

\section{BACIA DO CURURUPE}

O alto curso da Bacia do Cururupe é caracterizado por apresentar as cotas mais elevadas da região, vales encaixados, amplos anfiteatros em cabeceiras de drenagem e baixo índice de ocupação. Em contraste, a porção do baixo curso, desenvolve-se em cotas baixas, com vales de fundo plano e em trechos meandrantes do rio. Na bacia, os pontos favoráveis encontram-se nas proximidades da estrada que liga lhéus a Buerarema (BA-001), pois o traçado desta via acompanha em grande parte o divisor de águas entre as bacias dos rios Cururupe e Santana, situação bastante favorável para a prospeção.

A investigação concentrou-se em três locais ao longo desta bacia. O primeiro refere-se à parte baixa da bacia, onde foi examinada a área do atual depósito de residuos da Cidade de llhéus, denominada de Cururupe (Sítio 3). Esta investigação foi realizada com o objetivo de avaliar as características ambientais da área, para uma possivel transformação em aterro sanitário e assim possibilitar a recuperação desta área degradada.

No alťo curso da bacia foram identificados mais dois locais que se mostraram mais adequados à implantação do futuro aterro. O primeiro foi denominado de Fazenda Omologi (Sítio 4) e o segundo, Fazenda Arabela (Sítio 5).

\section{CURURUPE (SItio 3)}

Corresponde a atual área de disposição de resíduos do município.

\section{Geomorfologia}

A área está inserida na margem esquerda do Rio Cururupe, a menos de $1 \mathrm{~km}$ de sua foz. É desenvolvida sobre topografia suavemente ondulada, associada à terraços da planície aluvionar do rio, com cerca de 1 a $2 \mathrm{~m}$ acima do leito atual do rio. O Rio Cururupe, nesta área, possui padrão 
altamente meandrante, com amplo vale (cerca de 200 a $300 \mathrm{~m}$ de largura) de fundo plano, associado à planície aluvionar. Esta planície desenvolve-se margeando morrotes convexos com cotas máximas de 20 a 40m, correspondentes a testemunhos do Grupo Barreiras, cobrindo rochas do embasamento rochoso.

\section{Geologia}

O contexto geológico desta área corresponde a depósitos fluviais, os quais recobrem e retrabalham, em parte, sedimentos quaternários de uma antiga planície de maré. A planície de origem fluvial está encaixada entre morrotes arredondados de topo convexo constituídos por testemunhos do embasamento rochoso, em adiantado estado de degradação intempérica, evidenciado pela cobertura pedológica de solos residuais síltico-argilosos de coloração marrom avermelhado. Parte destes morrotes ainda abrigam testemunhos da cobertura do Grupo Barreiras, constituídos de camadas areno-siltosas (fotos 22 e 23).

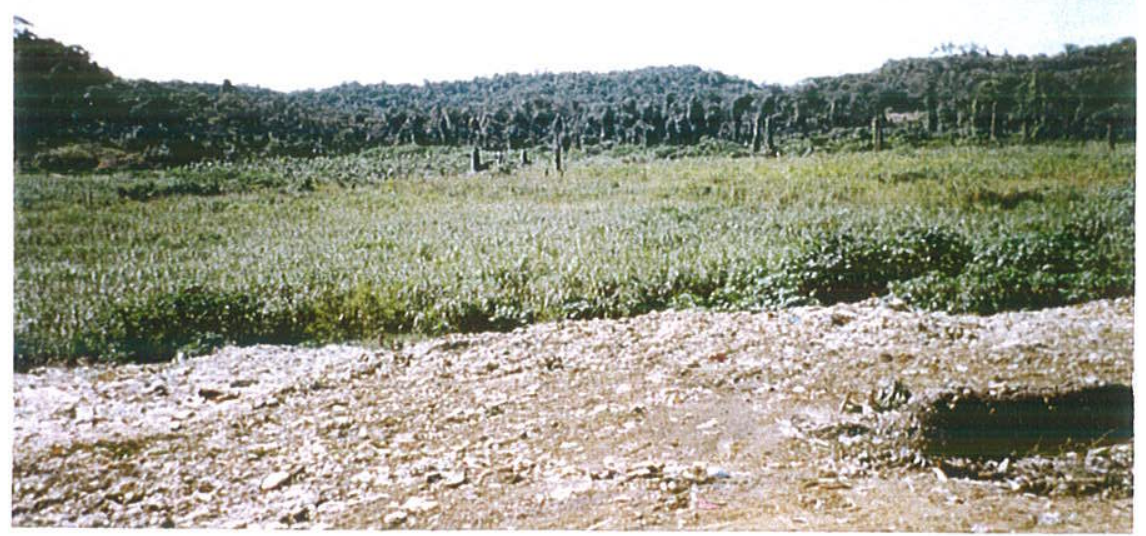

Foto 22 - Em primeiro plano, planície aluvionar do Rio Cururupe com disposição de resíduos. No fundo, morros testemunhos do embasamento cobertos pelo Grupo Barreiras.

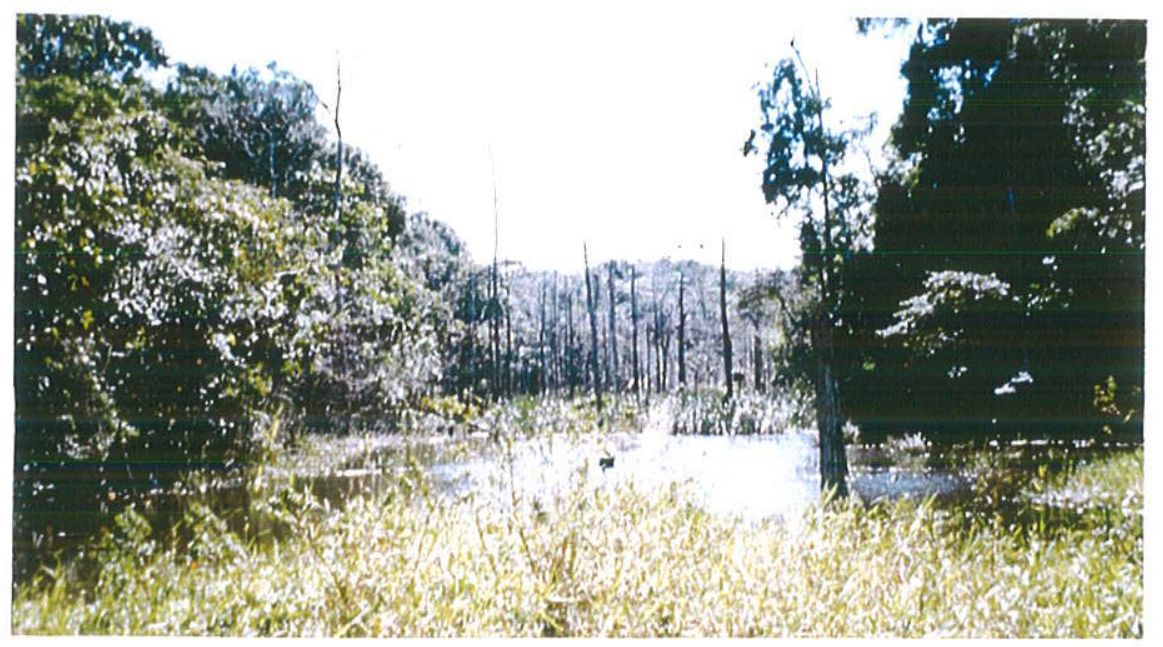

Foto 23 - Alagamento na planície do Rio Cururupe causado pelo acúmulo de resíduos. 


\section{Hiolrologia}

A proximidade da área com a linha de costa (cerca de $1 \mathrm{~km}$ em linha reta) e sua localização na porção baixa da planície fluvial (entre 3 a $6 \mathrm{~m}$ do nível do mar) condicionam um nível da água raso, com ocorrências de ambientes lacustres e pantanosos. Estes ambientes estão associados a meandros abandonados, com nivel de água fortemente influenciado pelas oscilações da maré e o conseqüente refluxo das águas do Rio Cururupe.

Sobre os terraços emersos acima do nível da água, a drenagem é pouco desenvolvida, devido a alta permeabilidade dos sedimentos aluvionares e do material coluvionar associado às encostas dos morrotes.

\section{Análise da aptidão}

Esta área é totalmente desfavorável para a disposição de resíduos, devido às caracteristicas fisiográficas apresentadas, as quais condicionam a infiltração direta do percolado no aqüifero (solo de elevada permeabilidade e nível d" água raso), bem como não permite a coleta e o armazenamento dos líquidos percolados pela ausência de gradiente topográfico e nivel elevado do freático.

Além disto, soma-se a grande proximidade da linha de costa e do leito principal do Rio Cururupe. Ressaltamse ainda, que devido à proximidade da linha de costa, a contaminação do rio neste local, provavelmente compromete a faixa de praia existente na sua foz, pondo em risco a saúde dos banhistas que freqüentam esta área.

\section{FAZENDA OMOLOGI ( Sítio 4)}

Localiza-se no lado esquerdo da estrada BA-251 no sentido Buerarema.

\section{Geomorfologia}

A área está inserida no contexto de morros de topos aplainados, na encosta Sudeste do divisor de águas entre a bacia do Rio Santana, a Noroeste e a do Rio Cururupe, a Sudeste. Possui dois anfiteatros semicirculares bem desenvolvidos, com cerca de 80 a 100 metros de eixo maior e declividades entre $20^{\circ}$ e $30^{\circ}$. O desnivel entre o topo dos morros aplainados e os fundos dos vales varia entre 20 a $40 \mathrm{~m}$ (fotos 24 e 25 ).

\section{Geologia}

A área desenvolve-se sobre gnaisses granulíticos bandados do Complexo théus e testemunhos do Grupo Barreiras. Na superfície predomina uma cobertura de solo residual da 

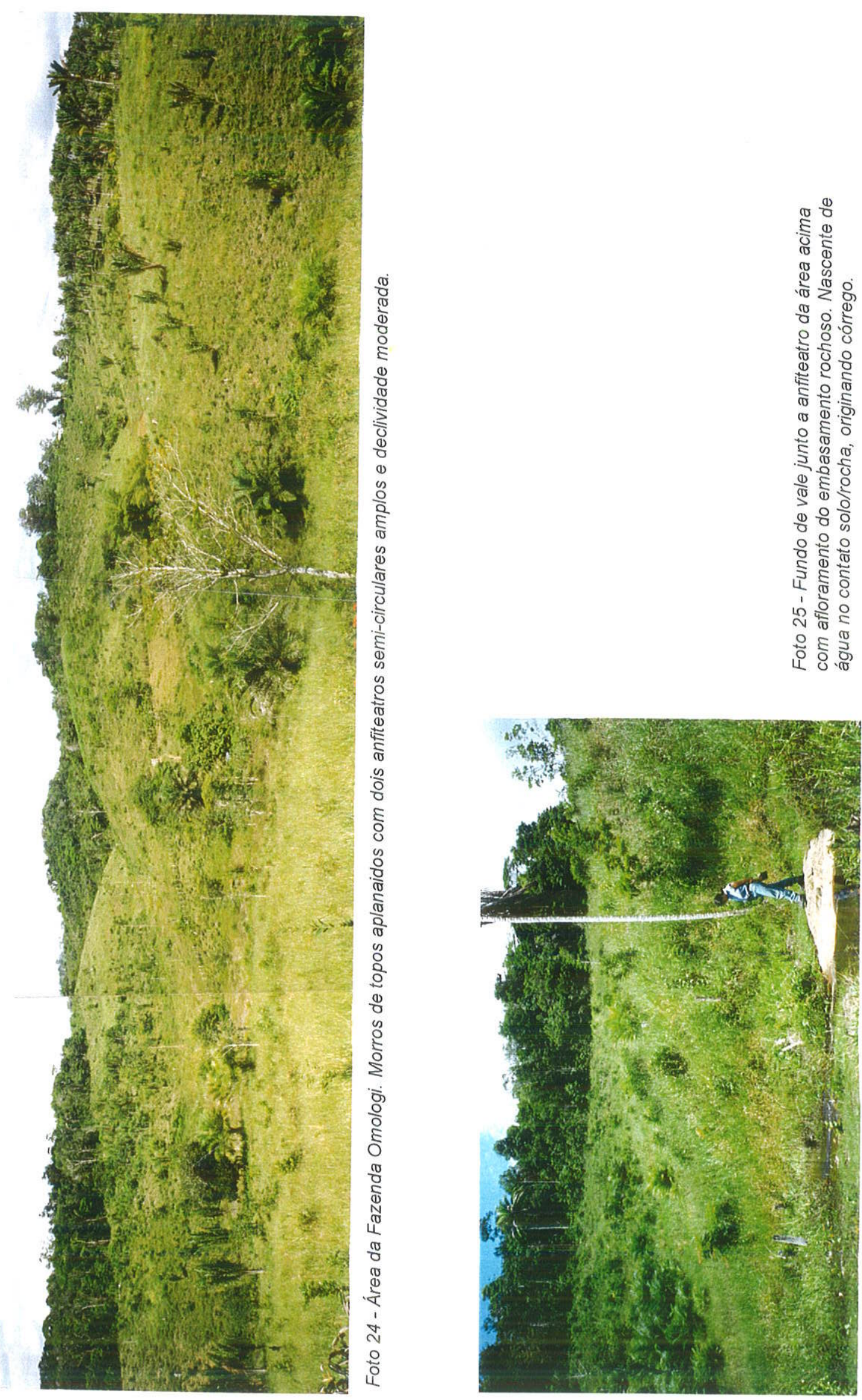
unidade arenosa a sittosa de arenitos impuros do Grupo Barreiras. No fundo dos vales, ao longo de pequenos cursos d'água, aflora o gnaisse. Este é composto por bandas centimétricas a decimétricas de coloração cinza claro a escuro, às vezes róseo, de composição quartzo-feldspática com variação no conteúdo de minerais máficos (ortopiroxênios). Nos locais observados notou-se uma intensa foliação, paralela ao bandamento composicional, expressa pelo estiramento dos minerais, indicando tratar-se de uma zona de cisalhamento. A estrutura principal destes gnaisses granulíticos é o bandamento metamórfico paralelo à follação de estiramento, com direção geral N25-30E e mergulho sub-vertical. Diques de rocha básica afanítica, com espessura observada de até um metro ocorrem cortando os gnaisses. São verticais com direção geral N60-80E. O sistema de fraturas é formado essencialmente pelo conjunto $\mathrm{N} 30 \mathrm{~W}$, subvertical, de comprimento métrico a decamétrico, sendo pouco freqüentes em comparação à incidência deste conjunto nas rochas metabásicas da Área Embasa. Fraturas menores, verticais e isoladas, ocorrem na direção N60W, paralelas aos diques básicos.

\section{Manto de intemperismo}

O manto de intemperismo é composto pela cobertura terciária do Barreiras, observada em corte de um testemunho junto à estrada. É formada por arenitos impuros de coloração avermelhada, granulação média, friável, com matriz siltica a argilosa.

As encostas e topos da área são cobertos principalmente por solo residual destes arenitos impuros, às vezes misturado com material intempérico dos gnaisses granulíticos. Apresenta textura predominantemente areno-siltosa, localmente argilosa, com grânulos de feldspato e quartzo. Fragmentos de crostas arenosas ferruginosas são freqüentes. A espessura desta cobertura é bastante variável, estimando-se cerca de 2 a $20 \mathrm{~m}$.

\section{Hidrologia}

Pelo fato da área estar inserida no contexto de divisor de águas, o volume de água superficial é muito baixo. O contraste de permeabilidade existente entre a cobertura areno-siltosa $e$ - embasamento rochoso pouco permeável, condiciona o acúmulo de água nesta interface, originando nascentes no contato entre rocha e a cobertura, formando um pequeno córrego (foto 25).

\section{Análise da aptidão}

Os aspectos favoráveis são: rocha pouco fraturada e relativamente impermeável; distância de $4,5 \mathrm{~km}$ da orla marítima; facilidades de acesso (com necessidade de melhorias), distância do centro gerador de lixo de aproximadamente $11 \mathrm{~km}$. 
Os desfavoráveis: presença de afloramento rochoso no fundo dos vales, composição da cobertura superficial predominantemente arenosa e pouca disponibilidade de material de empréstimo no próprio local, impacto visual para os usuários estrada BA-251, necessidade de melhorias (alteamento da pista e obras de drenagem) na estrada de acesso numa extensão aproximada de $2,5 \mathrm{~km}$.

\section{FAZENDA ARABELA (Sítio 5)}

\section{Geomorfologia}

A área Fazenda Arabela, com cotas topográficas que variam entre 100 e 130 m, está inserida no domínio de morros com topos aplainados, em situação de divisor de águas (foto 26).

As grotas que ocorrem na área representam as cabeceiras de um afluente da margem esquerda do médio curso do Rio Cururupe, que nascem em cotas de $120 \mathrm{~m}$, atingindo o curso do Rio Cururupe, aproximadamente na cota 40.

É composta por três amplos anfiteatros semicirculares a elípticos que convergem para uma linha de drenagem. A declividade da superfície ao longo dos anfiteatros varia entre $15^{\circ}$ e $25^{\circ}$, em direção aos fundos de vales. As dimensões do eixo maior dos anfiteatros variam de 60 a $120 \mathrm{~m}$.

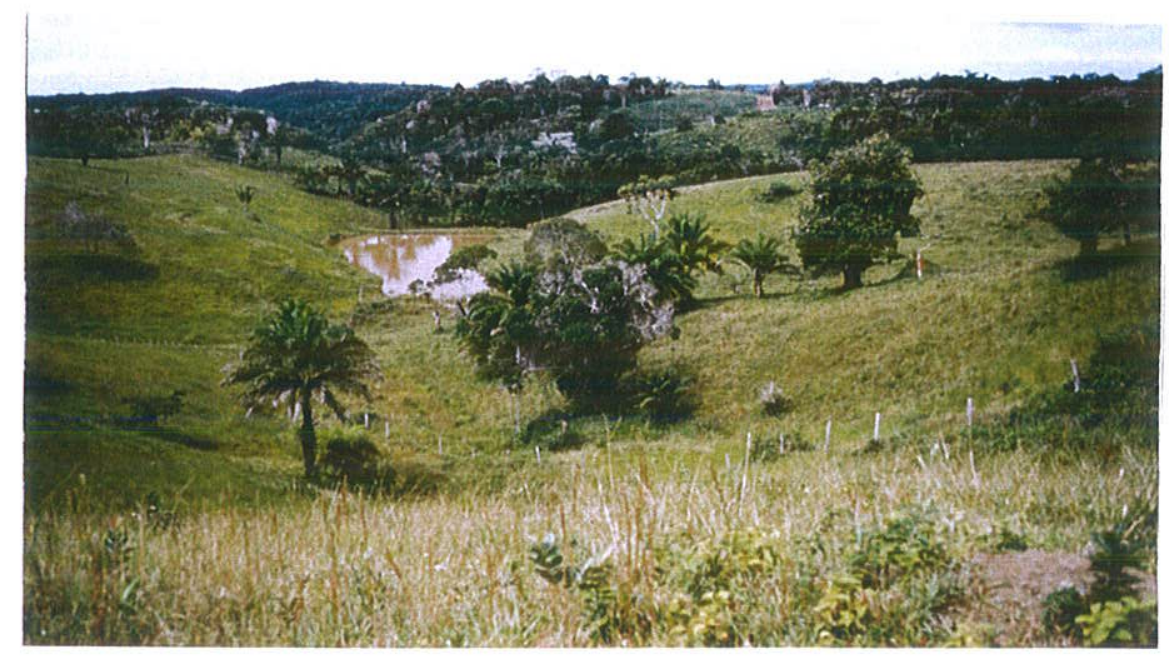

Foto 26 - Área Fazenda Arabela. Vista no sentido jusante de um dos anfiteatros. Ao fundo, represamento artificial junto a drenagem principal da área.

\section{Geologia}

Seguindo o padrão regional da geologia ao Sul de Ilhéus, a área está inserida no domínio de rochas granulíticas félsicas e básicas do Complexo Ilhéus na base, cobertas por testemunhos sedimentares do Grupo Barreiras. Não se observam afloramentos do embasamento rochoso 


\section{Manto de intemperismo}

A área está coberta por material intemperizado do Grupo Barreiras, constituído no topo por um regolito areno-siltoso, localmente argiloso, de coloração marrom claro, com blocos e calhaus isolados de concreções ferruginosas. A cerca de 2 a $3 \mathrm{~m}$ acima do fundo do vale principal da área, observou-se uma camada de argilito de coloração cinza claro, com espessura mínima de $50 \mathrm{~cm}$, atribuída ao Barreiras. Estima-se que o embasamento de rochas granulíticas esteja a cerca de 2 a $5 \mathrm{~m}$ abaixo do fundo do vale principal.

\section{Miorologyia}

Ocorre um brotamento de água em pontos ao longo da camada de argilito nas proximidades do fundo do vale, devido a rormação de um aqüífero suspenso. No fundo da drenagem principal há um represamento artificial do escoamento supenficial formando um lago (foto 26).

\section{Análise da aptiỡo}

Dentre os aspectos favoráveis destacam-se: ausência de afioramento rochoso; cobertura superficial espessa - composta por camadas de argilitos intercaladas em sedimentos silticoarenosos; disponibilidade de material de empréstimo no próprio local, distante do mar $(7,5 \mathrm{~km}$ em linha reta), ausência de matas, área ocupada por pastagens, ausência de moradia no local.

Os desfavoráveis são: a distância ao centro de llhéus $(20 \mathrm{~km})$ e $13 \mathrm{~km}$ de acesso não pavimentado.

\section{SETOR OESTE/SUDOESTEDE ILHEUUS}

Os sítios analisados no Setor Oeste/Sudoeste estão inseridos na Bacia Hidrográfica do Rio Cachoeira.

Em função das caracteristicas físicas do vale do Rio Cachoeira, que apresenta amplas planícies de inundação e morros isolados com cotas e áreas reduzidas, associadas à intensa ocupação, a ocorrência potencial de situações favoráveis para implantação de aterros sanitários está restrita às proximidades do limite desta bacia, em situaçőes de divisor de águas entre bacias. Devido ao menor índice de ocupação, as investigações concentraram-se na margem direita do rio. Foram delimitadas dois sítios potencialmente favoráveis que foram denominados de: MARIA JAPE I (Sítio 6) e MARIA JAPE II (Sitio 7) 


\section{MARIA JAPE I (Sítio 6)}

O acesso principal é pela rodovia llhéus - Itabuna, e o secundário, através de uma estrada não pavimentada que interliga a Ponte do Banco da Vitória (sobre o Rio Cachoeira) à Vila de Maria Jape (foto 27).

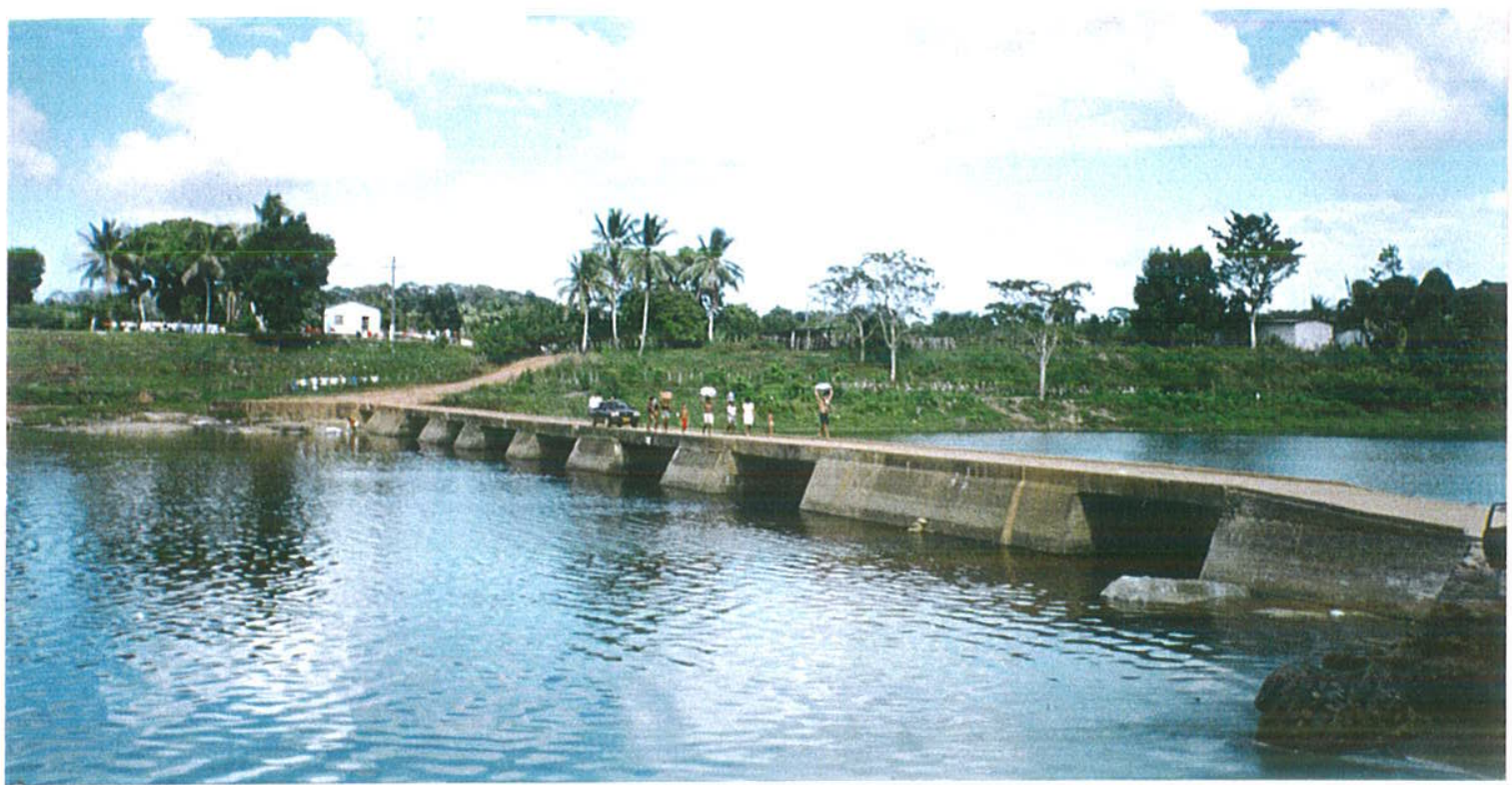

Foto 27 - Ponte do Banco da Vitória, sobre o Rio Cachoeira. Única travessia que interliga os setores Norte e Sul do município de Ilhéus

\section{Geomorfologia e Hidrologia}

Está inserida no contexto de topos aplainados entre cotas de 90 a $110 \mathrm{~m}$, representando uma situação de divisor de águas entre a Bacia do Ribeirão Pirata (sub-bacia tributária do Rio Cachoeira) e afluentes menores que drenam diretamente para o Rio Cachoeira. A superfície do topo é suavemente ondulada, com desníveis de até $5 \mathrm{~m}$. Estima-se que a área apresenta cerca de $300 \mathrm{~m}$ de comprimento e largura variando de 100 a $150 \mathrm{~m}$ (foto 28).

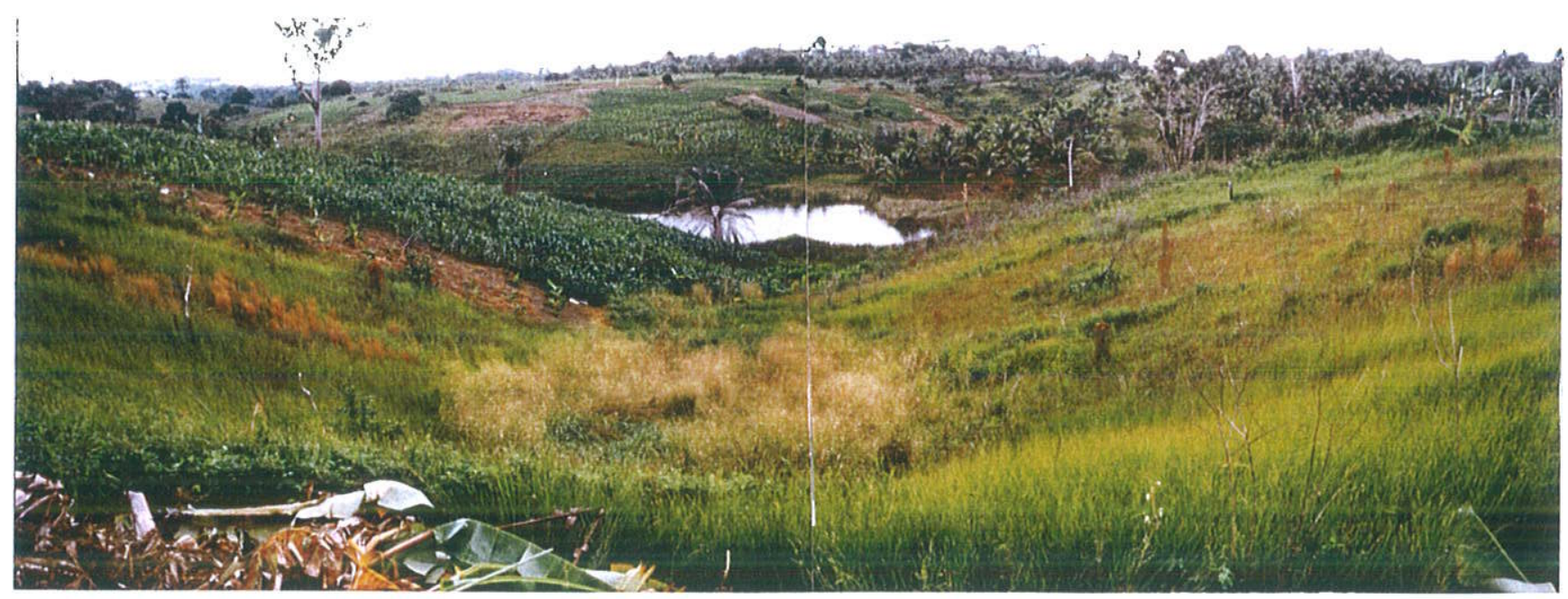

Foto 28 - Vista geral da área Maria Jape I. Anfiteatro com vertentes suaves e represamento no fundo do vale. 


\section{Geologia e manto de intemperismo}

Esta área desenvolve-se sobre a zona de transição entre o material intempérico residual do embasamento granulítico (gnaisses tonalíticos e básicos) e manchas residuais da cobertura arenitica do Grupo Barreiras. Não se observam afloramentos rochosos, estimando-se uma espessura de material intempérico entre 2 a $6 \mathrm{~m}$, muito variável.

\section{Análise da Aptidão}

Do ponto de vista geológico, geomorfológico e hidrológico considera-se esta área muito favorável para instalação de um aterro sanitário. Pois possui cobertura pedológica espessa e pouco permeável (siltico-argilosa), vertentes suaves a medianamente inclinadas, grande volume e posição alta em relação a cursos de água importantes.

O principal aspecto desfavorável é a precariedade da ponte sobre o Rio Cachoeira, que fica submersa nas cheias do rio.

\section{MARIA JAPE II (SItIO ?)}

A principal via de acesso é semelhante da Maria Jape I, continuando a estrada secundária para sentido Sul.

\section{Geomorfologia}

Localiza-se, também, em contexto de divisor de águas, neste caso entre o baixo curso das bacias dos rios Cachoeira e Santana, onde os vales tipo anfiteatros estão associados às cabeceiras de um afluente da margem direita do baixo curso do Cachoeira. Desenvolve-se em cotas entre 80 a $110 \mathrm{~m}$. É formada por três anfiteatros convergentes, cada um, com cerca de $100 \mathrm{~m}$ de eixo maior e $60 \mathrm{~m}$ de eixo menor. As inclinações das vertentes destes anfiteatros variam entre $15^{\circ}$ a $25^{\circ}$. 0 topo aplainado, relativamente estreito, corresponde a área ao divisor topográfico. Apresenta cerca de 100 a $150 \mathrm{~m}$ de largura.

\section{Geologia e manto de intemperismo}

A área desenvolve-se sobre uma cobertura intempérica de coloração amarelada a avermelhada, de composição arenosa a siltosa, com horizontes siltico-argilosos. Nas proximidades dos fundos dos anfiteatros ocorrem matacões de esfoliação esferoidal indicando a presença do embasamento rochoso. Estes matacões são compostos por granitos e gnaisses granulíticos de coloração cinza a rósea e de granulação grossa. Próximo ao topo desta cobertura são freqüentes blocos e calhaus de material arenoso cimentado por material ferruginoso (limonita), 
representando testemunhos de crostas detrito-lateríticas. A espessura desta coberiura pedológica varia entre 2 a $8 \mathrm{~m}$, sendo mais espessa no topo e mais delgada no fundo dos vales, onde afloram os matacões.

\section{Hidrologia}

Representa uma situação de cabeceira de drenagem, onde as rotas do escoamento superficial, que partem desta área convergem para um afluente da margem direita de um córrego, que por sua vez, deságua no Rio Cachoeira, após um percurso de aproximadamente $5 \mathrm{~km}$, sobre um desnivel total de $80 \mathrm{~m}$.

No contato entre a cobertura de solo e a zona de rocha intemperizada com blocos de esfoliação ocorre o brotamento de água em função do contraste de permeabilidade. Esta água é represada arificialmente formando um lago no fundo de um dos anfiteatros .

\section{Análise da aptidão}

Devido as características físicas semehantes às descritas para Maria Jape !, concluiu-se que esta área também é muito favorável para receber um aterro sanitário.

Como aspectos desfavoráveis destaca-se o problema de acesso devido a submersão da ponte nas épocas de cheia do rio.

\section{SETOR NORTE ENOROESTE DE ILHEUS}

Os sítios analisados no Setor Norte e Noroeste de lihéus estão inseridos na Bacia Hidrográfica do Rio Almada.

De modo geral, a bacia do Rio Almada apresenta poucas regiões disponiveis com aptidão para aterros sanitários porque grandes áreas encontram-se inseridas na Área de Proteção Ambiental da Lagoa Encantada e em áreas do manancial do Rio lguape, responsável por parte do abastecimento de água de lihéus. As regiões remanescentes são muito próximas a linha de costa ou muito distantes da zona Sul de llhéus.

Neste setor foram identificados os sítios Carobeira (Sítio 8) e Itarini (Sítio 9).

\section{CAROBEIRA (Sítio 8)}

A região conhecida como Carobeira está inserida em uma pequena bacia hidrográfica tributária da margem direita do baixo curso do Rio Almada. $O$ acesso é feito através da estrada que liga Ithéus a Sambaituba, passando pela Vila da Carobeira. 


\section{Geomorfologia}

O local identificado está inserido no flanco Leste de um estreito divisor topográfico entre uma sub-bacia tributária do baixo curso do Rio Almada e a Bacia do Rio lguape, a Oeste (aḱual área de captação de água para abastecimento de llhéus). A área desenvolve-se entre cotas de $110 \mathrm{e}$ $80 \mathrm{~m}$, sendo caracterizada por anfiteatros encaixados e profundos, com encostas fortemente inclinadas, entre $30^{\circ}$ e $40^{\circ}$ e fundos de vales estreitos. A morfologia segue o padrão regional dos divisores de águas em cotas mais elevadas e topos aplainados. No sítio Carobeira, as áreas planas são estreitas, variando entre 100 a $50 \mathrm{~m}$ de largura.

\section{Geologia e manto de intemperismo}

A área desenvolve-se sobre gnaisses básicos (granulitos básicos) e tonalíticos, caracterizados por coloração escura (negra a cinza escuro). Em superfície ocorrem os produtos de atteração destas rochas, formados por solos de coloração avermelhada e composição síltica a argilosa. Em trechos dos topos aplainados nota-se fragmentos de concreções limoníticas e crostas lateríticas arenosas, sugerindo tratar-se de restos da cobertura de idade terciária do Grupo Barreiras.

\section{Hidrologia}

O local representa uma das cabeceiras de uma pequena bacia hidrográfica que deságua no baixo curso do Rio Almada. Apesar desta bacia apresentar área pequena, vários cursos de água, com pequeno volume, são drenados diretamente para o curso principal desta drenagem, a qual é aproveitada por sítios e fazendas a beira do Rio Almada. A cabeceira em questão, dista cerca de $1 \mathrm{~km}$ deste curso de água principal, o qual, por sua vez, possui $3 \mathrm{~km}$ de exíensão até atingir o Rio Almada.

\section{Análise da aptidão}

Os aspectos físicos favoráveis para implantação do aterro sanitário nesta área são: situação topográfica em cotas elevadas e a cobertura de material sítico-argiloso sobre o embasamento rochoso com baixo grau de fraturamento.

Os aspectos desfavoráveis são: anfiteatros muito fechados, com encostas de alta declividade $\left(30\right.$ a $\left.40^{\circ}\right)$, associados à fundos de vales muito estreitos. A drenagem do flanco Leste do divisor é coletada por um córrego, o qual deságua diretamente no baixo curso do Rio Almada. Nesta região, a planície do Rio Almada é ocupada por inúmeros sítios e fazendas, e existe uma importante área de lazer para a população de llhéus. 


\section{ITARIRI (Sítio 9)}

O sítio Itariri está inserido na Bacia do Rio Tiriri (ou Itariri), afluente da margem direita do médio curso do Rio Almada. O acesso principal é realizado pela Rodovia BA-262 (Ilhéus - Uruçuca) e o secundário, por uma estrada não pavimentada.

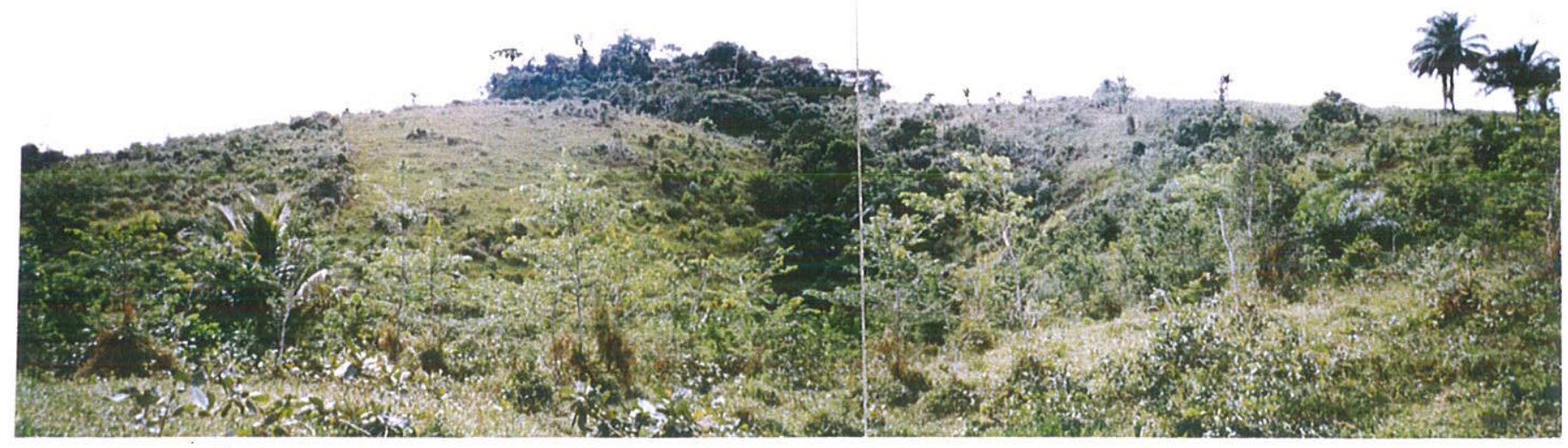

Foto 29 - Área Itariri. Anfiteatro de cabeceira de drenagem com vertentes de inclinação média-alta (centro da foto).

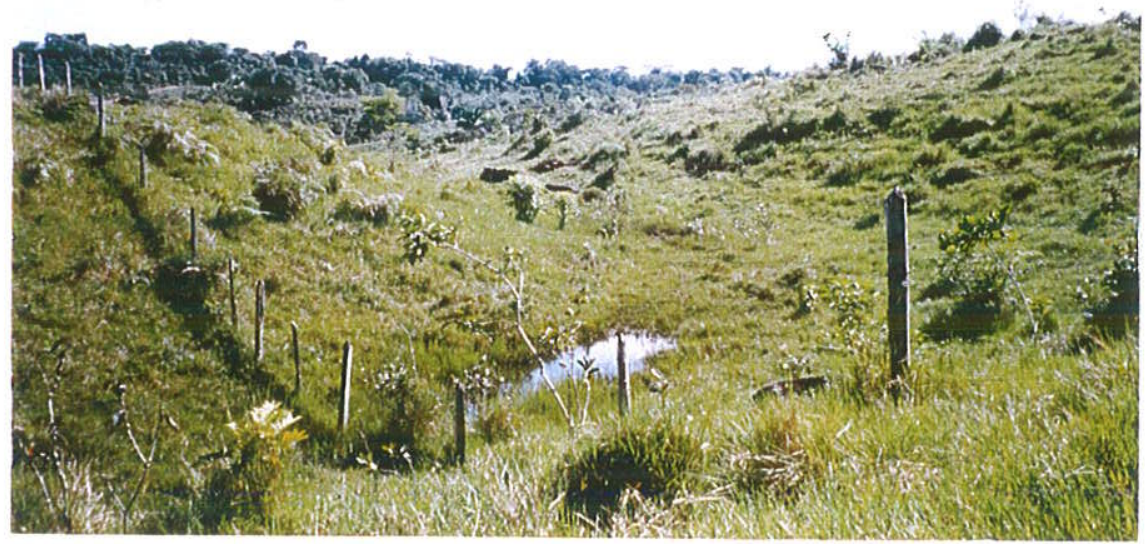

Foto 30 -Vertente do anfiteatro com afloramentos de gnaisse e metabásicas

Foto 31 - Captação deágua a jusante do anfiteatro para abastecimento local.

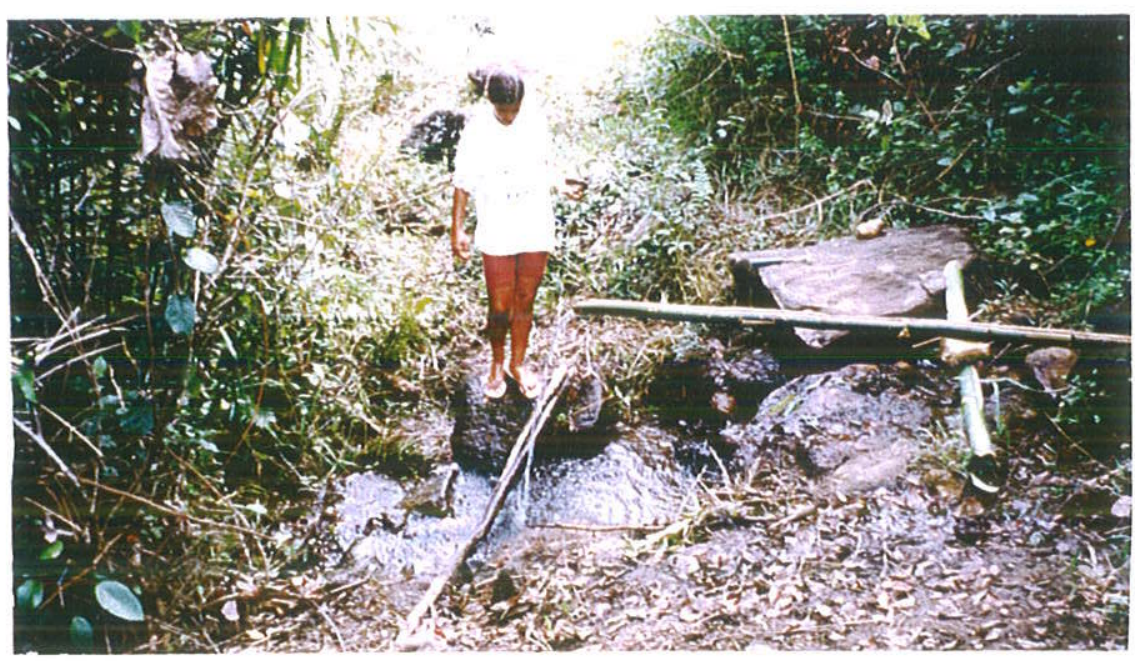




\section{Geomoriologia}

Desenvolve-se em cotas entre 70 e $100 \mathrm{~m}$, caracterizando uma região de planalto interior de cabeceiras de drenagem, onde agrupamentos de morros ocorrem isolados por planícies alveolares, de superfície plana Associadas às encostas dos morros ocorrem cabeceiras de drenagens em vales tipo anfiteatros, com dimensões entre 50 a $100 \mathrm{~m}$ de eixo maior, que terminam junto às planícies alveolares (foto 29).

\section{Geologia e manto de intemperismo}

Ocorre sobre produtos de alteração intempérica de gnaisses granulíticos de composição tonalítica a granítica com intercalações de metabásicas. Esta cobertura intempérica é formada por material siltico-argiloso de coloração avermelhada a alaranjada, com espessura de alguns metros. Há afloramentos rochosos por toda a encosta do anfiteatro (foto 30). Nas planícies alveolares ocorrem acumulações de material coluvionar e aluvionar, de composição arenosa a argilosa, provavelmente de espessura métrica.

\section{Hidrologia}

Está inserida em contexto de uma importante zona de divisor de águas, em região de cabeceiras de duas bacias: uma situada a Sul-Sudeste, Bacia do Rio Iguape, e outra, a Oeste da área, a Bacia do Rio Tiriri, que por sua vez, é um afluente do médio curso do Rio Almada, após cerca de $7,5 \mathrm{~km}$ de percurso.

Acompanhando a morfologia geral da área, as planicies aluviais entre morros caracterizam-se por nível de água raso e zonas encharcadas, com vegetação típica de alagadiços.

\section{Análíse da aptidão}

Como aspecto favorável destacam-se as condições de acesso até o local, pois é predominantemente asfaltado e apresenta proximidade com a porção Norte da cidade.

Os aspectos desfavoráveis referem-se ao desnivel relativamente pequeno entre os anfiteatros e as planícies - onde o nivel da água é raso, ocorrência de afloramentos de rocha ao longo de toda a vertente do anfiteatro, pouca disponibilidade de material de cobertura (áreas de emprésţimo), captação de água no vale a jusante (foto 31), distância de $20,5 \mathrm{~km}$ entre o centro de lihéus e o sítio, e necessidade de melhorias no trecho não pavimentado da estrada. 


\begin{tabular}{|c|c|c|c|c|c|c|c|c|c|c|c|c|c|c|}
\hline \multirow{2}{*}{\multicolumn{2}{|c|}{$\begin{array}{c}\text { indicadores } \\
\text { sítios }\end{array}$}} & \multicolumn{3}{|c|}{ formação superficial } & \multicolumn{3}{|c|}{ geologia/geomorfologia } & \multicolumn{6}{|c|}{ características bióticas e sócio - ambientais } & \multirow{3}{*}{ 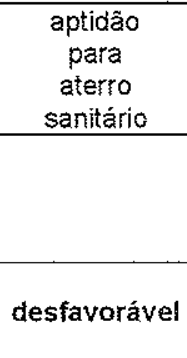 } \\
\hline & & $\begin{array}{l}\text { compo- } \\
\text { sição }\end{array}$ & $\begin{array}{l}\text { espes- } \\
\text { sura } \\
(\mathrm{m})\end{array}$ & $\begin{array}{l}\text { permea- } \\
\text { bilidade }\end{array}$ & litologia & $\begin{array}{c}\text { declividade } \\
\text { das } \\
\text { vertentes } \\
(0)\end{array}$ & $\begin{array}{c}\text { amplitude } \\
\text { topográfica } \\
\text { (metros) }\end{array}$ & $\begin{array}{l}\text { vida útil } \\
\text { estimada }\end{array}$ & $\begin{array}{c}\text { condições } \\
\text { de acesso } \\
\text { (dimensāo) }\end{array}$ & $\begin{array}{l}\text { distância do } \\
\text { centro de } \\
\text { lihéus }(\mathrm{km})\end{array}$ & $\begin{array}{c}\text { distância de } \\
\text { núcleo } \\
\text { urbano mais } \\
\text { próximo }(\mathrm{Km})\end{array}$ & $\begin{array}{c}\text { ocupação } \\
\text { da } \\
\text { área }\end{array}$ & $\begin{array}{l}\text { impacto } \\
\text { visual }\end{array}$ & \\
\hline \multirow{5}{*}{ 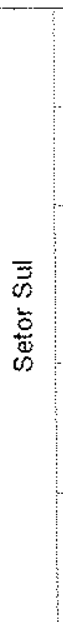 } & $\begin{array}{c}\text { Embasa } \\
\text { (Área 1) }\end{array}$ & $\begin{array}{l}\text { argilo a } \\
\text { arenosa }\end{array}$ & $4-10$ & $\begin{array}{l}\text { baixa a } \\
\text { média }\end{array}$ & $\begin{array}{l}\text { granulitos } \\
\text { básicos }\end{array}$ & $15-30$ & $20-40$ & $<10$ anos & $\begin{array}{c}\text { näo } \\
\text { pavimentado } \\
(2,5 \mathrm{~km})\end{array}$ & 10 & 1,5 & $\begin{array}{l}\text { pastagem e } \\
\text { capoeira cl } \\
\text { piaçava }\end{array}$ & alto & \\
\hline & $\begin{array}{c}\text { Areal } \\
\text { (Área 2) }\end{array}$ & $\begin{array}{l}\text { areias, } \\
\text { siltitose } \\
\text { argilitos }\end{array}$ & $>20$ & alta & $\begin{array}{c}\text { areias, siltitos } \\
\text { e argilitos }\end{array}$ & $10-50$ & $20-50$ & $>15$ anos & $\begin{array}{c}\text { näo } \\
\text { pavimentado } \\
(2,0 \mathrm{~km})\end{array}$ & 16 & 1,5 & $\begin{array}{c}\text { mineração } \\
\text { de areia }\end{array}$ & baixo & desfavorável \\
\hline & $\begin{array}{c}\text { Cururupe } \\
\text { (Área 3) }\end{array}$ & $\begin{array}{c}\text { solos } \\
\text { hidromór } \\
\text { ficos, } \\
\text { areias } \\
\text { siltosas. }\end{array}$ & $1 \sim 2,5$ & $\begin{array}{l}\text { alta a } \\
\text { média }\end{array}$ & $\begin{array}{c}\text { solos } \\
\text { hidromór- } \\
\text { ficos, areias } \\
\text { siltosas, } \\
\text { areias }\end{array}$ & horizontal : & $3-6$ & - & $\begin{array}{c}\text { não } \\
\text { pavimentado } \\
(1,0 \mathrm{~km})\end{array}$ & 13 & 1 & lixăo & baixo & desfavorável \\
\hline & $\begin{array}{c}\text { Fazenda } \\
\text { Omologi } \\
(\text { Área } 4)\end{array}$ & $\begin{array}{l}\text { areno- } \\
\text { sitosa }\end{array}$ & $2-20$ & $\begin{array}{l}\text { média a } \\
\text { alta }\end{array}$ & $\begin{array}{l}\text { gnaisses } \\
\text { granulticos e } \\
\text { Gp. Barreiras }\end{array}$ & $20-30$ & $70-80$ & 15 anos & $\begin{array}{c}\text { nao } \\
\text { pavimentado } \\
(4,0 \mathrm{~km})\end{array}$ & 11,5 & $<1$ & pastagem & médio & favorável \\
\hline & $\begin{array}{l}\text { Fazenda } \\
\text { Arabela } \\
\text { (Área 5) }\end{array}$ & $\begin{array}{l}\text { argilito, } \\
\text { areno- } \\
\text { siltosa }\end{array}$ & $>5$ & $\begin{array}{l}\text { baixa a } \\
\text { média }\end{array}$ & $\begin{array}{l}\text { granulitos } \\
\text { félsicose } \\
\text { básicos }\end{array}$ & $15-25$ & $100-130$ & 20 anos & $\begin{array}{c}\text { não } \\
\text { pavimentado } \\
(13 \mathrm{~km})\end{array}$ & 20 & 1,5 & pastagem & baixo & favorável \\
\hline \multirow{2}{*}{ 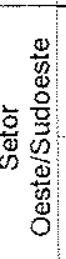 } & $\begin{array}{c}\text { Maria } \\
\text { Jape I } \\
\text { (Área 6) }\end{array}$ & $\begin{array}{l}\text { sítico- } \\
\text { argilosa }\end{array}$ & $2-8$ & $\begin{array}{l}\text { baixa a } \\
\text { média }\end{array}$ & $\begin{array}{l}\text { granulitose } \\
\text { Gp. Barreiras }\end{array}$ & - & $90-110$ & 15 anos & $\begin{array}{c}\text { não } \\
\text { pavimentado } \\
(6,5 \mathrm{~km})\end{array}$ & 16,5 & - & $\begin{array}{l}\text { capoeira e } \\
\text { plantaçāo } \\
\text { de coco }\end{array}$ & baixo & favorável \\
\hline & $\begin{array}{c}\text { Maria } \\
\text { Jape II } \\
\text { (Area } 7 \text { ) }\end{array}$ & $\begin{array}{l}\text { siticon } \\
\text { argilosa }\end{array}$ & $2-8$ & $\begin{array}{l}\text { baixa a } \\
\text { média }\end{array}$ & $\begin{array}{l}\text { granitose } \\
\text { gnaisses } \\
\text { granulíticos }\end{array}$ & $15-25$ & $80-110$ & 15 anos & $\begin{array}{c}\text { não } \\
\text { pavimentado } \\
(10,0 \mathrm{~km})\end{array}$ & 20 & 2,6 & pastagem & baixo & favorável \\
\hline \multirow{2}{*}{ 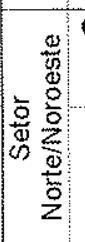 } & $\begin{array}{c}\text { Carobeira } \\
\text { (Área 8) }\end{array}$ & $\begin{array}{l}\text { sillico- } \\
\text { argliosa }\end{array}$ & 2.8 & $\begin{array}{l}\text { baixa a } \\
\text { média }\end{array}$ & $\begin{array}{l}\text { gnaisses } \\
\text { granulíticos }\end{array}$ & $30-40$ & $80-110$ & - & $\begin{array}{c}\text { não } \\
\text { pavimentado } \\
(7.0 \mathrm{~km})\end{array}$ & 15 & - & $\begin{array}{l}\text { vegetação } \\
\text { aroustiva, } \\
\text { capoeira }\end{array}$ & alto & desfavorável \\
\hline & $\begin{array}{c}\text { Itariri } \\
\text { (Área 9) }\end{array}$ & $\begin{array}{l}\text { arenosa. } \\
\text { siltico- } \\
\text { argilosa }\end{array}$ & $3-11$ & $\begin{array}{l}\text { alta a } \\
\text { baixa }\end{array}$ & $\begin{array}{l}\text { gnaisses } \\
\text { granuliticos }\end{array}$ & - & $70-100$ & 15 anos & $\begin{array}{c}\text { não } \\
\text { pavimentado } \\
(2.1 \mathrm{~km})\end{array}$ & 20,5 & $>0,5$ & pastagem & alto & favorável \\
\hline
\end{tabular}

Tabela 3.3 - Síntese dos sítios analisados no município de lihéus, BA (Conder/Equipe Umah, 1997). 


\subsubsection{Classificação geral dos sitios}

Dispondo da avaliação preliminar das aptidões dos sítios demarcados e pesquisados foi realizada uma primeira seleção de sitios, que teve como objetivo principal, excluir aqueles que apresentassem os condicionantes ambientais (principalmente físico e econômico) mais desfavoráveis à implantação e operação de aterros sanitários. Com isso, a continuidade do processo de seleção seria dirigido somente às áreas indicadas como de maior potencialidade, pois o objetivo final era atingir a seleção de três sítios alternativos para serem discutidos com a comunidade, na forma de audiência pública.

Dentre os nove sítios pesquisados, quatro foram excluidos já na primeira fase de seleção, que incluem o Embasa (Sítio 1), Areal (Sítio 2), Cururupe (Sítio 3) e Carobeira (Sítio 8).

O Sítio Embasa foi descartado pela sua proximidade com a estrada BA - 251, intermunicipal (interliga as cidades de llhéus e Buerarema) - pois ocasionaria grande impacto visual aos usuários da estrada; pela pequena dimensão da área, que restringiria a vida útil do aterro para o máximo de 10 anos. Em relação ao meio físico, não houve justificativa alguma para a exclusão da área, pois todos os condicionantes eram compatíveis ambientalmente com o empreendimento.

O Sítio Areal, ao contrário, foi descartado exclusivamente pelos condicionantes geológicos, geotécnicos e hidrogeológicos. Os principais motivos que os levaram a exclusão foram: a atta permeabilidade do terreno e conseqüente risco de contaminação do solo e do freático, baixo grau de compactação do substrato, o que poderia acarretar no comprometimento da estabilidade do aterro.

O Sítio Cururupe, área do lixão da cidade, também foi descartado principalmente pelos condicionantes físicos da área. Está inserido sobre a planície fluvial do Rio Cururupe, com influência da maré e nível d'água sub-afforante, apresentando elevado risco de contaminação das águas superficiais e subterrâneas.

O Sítio Carobeira foi descartado pelas incompatibilidades físicas e de uso e ocupação do solo. O sítio está inserido sobre anfiteatros muito fechados (com declividades entre 30 e $40^{\circ}$ ) o que geraria maiores custos operacionais e risco na estabilidade geotécnica do aterro. A área do entorno imediato é bastante freqüentada por turistas que utilizam o Rio Almada para recreação, tratando-se de uma importante área de lazer regional. Existe também a ocorrência de chácaras e sítios de veraneio imediatamente à jusante do sitio.

A etapa seguinte de seleção compreendeu a realização de uma hierarquização da aptidão dos sítios pré - selecionados na fase anterior (Fazenda Omologi, Fazenda Arabela, Maria Jape I, Maria Jape $1 /$ e Itariri)

Com o objetivo de permitir uma melhor sistematização da análise e hierarquização dos sítios, foram selecionados alguns indicadores técnicos e ambientais, e estabelecido um critério de pontuação e ponderação da importância relativa de cada indicador, de maneira a possibilitar o estabelecimento de uma avaliação e comparação qualitativa e quantitativa dos sítios. 
Para a hierarquização das áreas selecionadas, foram atribuidos alguns indicadores técnicos e ambientais, através de uma pontuação e ponderação de importância.

A justificativa atribuída para a adoção deste procedimento foi de possibilitar o estabelecimento de uma avaliação/comparação qualitativa e quantitativa das áreas selecionadas.

Os indicadores técnicos e ambientais considerados foram: distância em relação ao centro gerador de resíduos; condições de vias de acesso; vida útil do aterro sanitário; disponibilidade de solo para cobertura diária dos resíduos; ocupação atual da área; titulação da área; disponibilidade de infra-estrutura na área; características do solo; clima; e distância de área urbanas (tabela 3.4)

Estes indicadores receberam pontuação variando de 01 a 10 - de acordo com a sua maior ou menor adequação à implantação e operação de aterros sanitários. As maiores pontuações indicaram a maior adequação da área para o recebimento do aterro sanitário. (tabela 3.4)

Associada à esta pontuação, foram adotados pesos diferentes de importância para cada indicador, denominado de Coeficiente de Importância (Cl).

\begin{tabular}{|c|c|c|c|}
\hline $\begin{array}{l}\text { indicudores técnicos } \\
\text { ambientutis }\end{array}$ & justificativa & $\mathbf{C} \mathbf{X}^{*}$ & critério para hierarquização \\
\hline $\begin{array}{l}\text { distância en relaçĩo ao } \\
\text { centro gerador de residuos }\end{array}$ & $\begin{array}{l}\text { quanto maior a distancia pereorrida, } \\
\text { maiores gastos. }\end{array}$ & 5 & $\begin{array}{l}\text { maior distância - menor nota } \\
\text { menor distância - maior nota }\end{array}$ \\
\hline $\begin{array}{l}\text { condiçôes tas vias de } \\
\text { acesso }\end{array}$ & $\begin{array}{l}\text { quanto pior as condições de acesso, } \\
\text { matiores gastos com manutenção de } \\
\text { veículos }\end{array}$ & 5 & $\begin{array}{l}\text { necessidade de obras de melhoria / } 5 \text { pontos - constmagào de } \\
\text { ponte (1 ponto); alteamento de pista a drenagem (3) } \\
\text { nenhuma obra (5) } \\
\text { tipo de pavimento/relevo } 5 \text { pontes - estrada de tera muto } \\
\text { acidentada (1); estrada terra pouco acidentada (3) e pistat } \\
\text { asfaltada (5) }\end{array}$ \\
\hline vida útil to aterro sanitário & $\begin{array}{l}\text { perspestiva do atendimento para o } \\
\text { mínimo de } 15 \text { anos }\end{array}$ & 5 & $\begin{array}{l}\text { vida util: de } 10 \text { anos - } 5 \text { pontos ; superior a } 15 \text { anos - } 10 \\
\text { pontos. Valores intermediarios - notas proporcionats }\end{array}$ \\
\hline $\begin{array}{l}\text { disponibilidade de solo } \\
\text { cobertura }\end{array}$ & $\begin{array}{l}\text { aumento ou diminuição do cusḱo de } \\
\text { operaçũa do aterro }\end{array}$ & 3 & $\begin{array}{l}100 \% \text { no local } \mathrm{t}-10 \text { pontos } ; 50 \% \text { no local } \\
\mathrm{km}-7 \text { e restante até } 5 \\
\mathrm{~km}-100 \% \text { até } 5 \mathrm{~km}-5 \text { pontos }\end{array}$ \\
\hline titulação da átea & $\begin{array}{l}\text { particular ou pública - major ou menor } \\
\text { facilidade de desapropriaçăo da área }\end{array}$ & 1 & $\begin{array}{l}\text { propriedade municipal - } 10 \text { pontos; outras instituiģoes - } 7 \\
\text { pontos e propriedades particulares - } 5 \text { pontos }\end{array}$ \\
\hline $\begin{array}{l}\text { disponibilictade de intra- } \\
\text { estrutura }\end{array}$ & $\begin{array}{l}\text { disponibilikade de energia elctrica, } \\
\text { telefone, áges tratada, esgoto }\end{array}$ & 2 & $\begin{array}{l}\text { disponibilidade de energia elétrica/agua/teletone/rede de } \\
\text { esgoto - 10 pontos; dispon. de energia e mais } 02 \text { infia- } \\
\text { estruturas - } 9 \text { pontos; só energia - } 7 \text { pontos }\end{array}$ \\
\hline caracteristicas do solo & permeabilitade do substrato & 3 & $\begin{array}{l}\text { solos bastante argilosos - } 10 \text { pontos - siltosos ou argilo- } \\
\text { arenosos }-7 \text { pontos e solos arenosos }-5 \text { pontos }\end{array}$ \\
\hline clima & $\begin{array}{l}\text { inthềcia dos ventos quando lá } \\
\text { octipagăo urbanat no entorno }\end{array}$ & 1 & $\begin{array}{l}\text { varia de acordo com a distância dos núcleos urbanos o da } \\
\text { direşấo praferencial dos ventos }\end{array}$ \\
\hline distancia de áteas urbanas & $\begin{array}{l}\text { interferência com a populaçấo } \\
\text { consequêtente rejeição } \\
\text { empreendimento }\end{array}$ & 3 & $\begin{array}{l}\text { distância do núcleo urbano até o aterro sanitánio: } \\
\text { de } 500 \text { a } 1.000 \text { metros }-3 \text { pontos; de } 1001 \text { a } 1500 \mathrm{~m}-7 \\
\text { pontos; e acima de } 1.500 \text { metros }-10 \text { pontos }\end{array}$ \\
\hline
\end{tabular}

obs: * $\mathrm{Cl}=$ Coeficiente de Importância $\quad$ "t local (considerado distância até $1 \mathrm{~km}$ )

Tabela 3.4 : Indicadores e critérios utilizados para hierarquização dos sítios. Dados extraídos de Conder/Equipe Umah (1997)

O resultado da hierarquização realizada nos sítios selecionados é apresentado na tabela a seguir. 


\begin{tabular}{|c|c|c|c|c|c|c|c|c|c|c|c|}
\hline \multirow{2}{*}{ INDICADOR } & \multirow{2}{*}{$\begin{array}{l}\text { coef. } \\
\text { import. }\end{array}$} & \multicolumn{2}{|c|}{ OMOLOGI (Sitio 4) } & \multicolumn{2}{|c|}{ ARABELA (Sitio 5) } & \multicolumn{2}{|c|}{ M.JAPE | (Sítio 6) } & \multicolumn{2}{|c|}{ M.JAPE II (Sitio 7) } & \multicolumn{2}{|c|}{ ITARIRI (Sitio 9) } \\
\hline & & nota & $\begin{array}{c}\text { nota } \\
\text { ponderada }\end{array}$ & nota & $\begin{array}{c}\text { nota } \\
\text { ponderada }\end{array}$ & nota & $\begin{array}{c}\text { nota } \\
\text { ponderada }\end{array}$ & nota & $\begin{array}{c}\text { nota } \\
\text { ponderada }\end{array}$ & nota & $\begin{array}{c}\text { nota } \\
\text { ponderada }\end{array}$ \\
\hline disponiblidade solo cobertura & 3 & 7 & 21 & 10 & 30 & 10 & 30 & 7 & 21 & 7 & 21 \\
\hline Caracteristica do solo & 3 & 5 & 15 & 7 & 21 & 7 & 21 & 7 & 21 & 7 & 21 \\
\hline clima (diregáo predom.ventos) & 1 & 10 & 10 & 10 & 10 & 10 & 10 & 10 & 10 & 10 & 10 \\
\hline vida útil do aterro sanitário & 5 & 10 & 50 & 10 & 50 & 10 & 50 & 10 & 50 & 10 & 50 \\
\hline distäncia centro gerador resí. & 5 & 10 & 50 & 1 & 5 & 5 & 25 & 1 & 5 & 1 & 5 \\
\hline condiçóes via acesso & 5 & 7,13 & 35,65 & 6.65 & 33,25 & 5,21 & 26,05 & 5 & 25 & 9,79 & 48,95 \\
\hline ocupaçäo atual da área & 5 & 10 & 50 & 10 & 50 & 5 & 25 & 10 & 50 & 10 & 50 \\
\hline titulaçáo da área & 1 & 5 & 5 & 5 & 5 & 5 & 5 & 5 & 5 & 5 & 5 \\
\hline disponibilidade infra-estrutura & 2 & 7 & $\$ 4$ & 7 & 14 & 7 & 14 & 7 & 14 & 7 & 14 \\
\hline distancias áreas urbanas & 3 & 3 & 9 & 7 & 21 & 10 & 30 & 10 & 30 & 10 & 30 \\
\hline PONTUAÇAOO TOTAL & & & 259,65 & & 239,25 & & 226,05 & & 231 & & 254,95 \\
\hline HIERARQUIZAÇÄO & & & $1^{\circ}$ & & $3^{\circ}$ & & $5^{\circ}$ & & $4^{\circ}$ & & $2^{\circ}$ \\
\hline
\end{tabular}

Tabela 3.5 - Pontuação e hierarquização dos sítios selecionados. Extraído de Conder/Equipe Umah, 1997.

Conforme pode ser observado nas tabelas supracitadas, o processo de hierarquização adotado não considerou como indicativos ambientais os parâmetros geológicos, geomorfológicos e hidrológicos, inicialmente utilizado para a prospecção dos sítios, contrariando assim, os princípios que norteiam o processo seletivo de sítios, tema central desta dissertação.

Neste processo final de seleção, nota-se que o único parâmetro considerado para avaliar a aptidão dos terrenos em relação ao risco de contaminação do solo e das águas superficiais e subterrâneas, foi a característica do solo.

De acordo com a tabela 3.5 , os critérios de hierarquização para a característica do solo apresentou coeficiente de importância 3 , sendo menos importante que a distância do sítio em relação ao centro gerador de resíduos e as condições das vias de acesso. A importância para a disponibilidade de solo de cobertura e distâncias de núcleos urbanos receberam o mesmo grau de importância que as características do solo.

Portanto, este critério utilizado, deixa evidente que o processo de seleção final utilizado apresentou caráter predominantemente econômico, onde a preocupação com a proteção do solo e as águas ficaram a critério do projeto de implantação e operação do aterro. 
Este fato é confirmado pelos critérios de avaliação adotados para a característica do solo, onde a permeabilidade do substrato foi avaliada somente pela composição do solo (solos argilosos foram considerados os melhores e receberam nota 10; os solos siltosos ou argilo-arenosos - nota 7 e os solos arenosos - nota 5).

É impossivel avaliar a permeabilidade de um substrato de um sítio somente por este critério, pois sabe-se que além da composição do material, a espessura da camada insaturada, o coeficiente de permeabilidade e a composição granulométrica são critérios mínimos e essenciais para avaliar a condutividade hidraúlica de um substrato, e portanto, a sua fragilidade em relação a contaminação pelo chorume. Além disso, os aspectos geológicos (natureza do substrato rochoso e característica das estruturas rúpteis) não foram considerados neste parâmetro, não sendo incorporados no processo seletivo.

De acordo com a hierarquização e ponderação dos critérios acima estabelecidos, as áreas foram classificadas na seguinte ordem:

$$
\begin{aligned}
& \text { - } \quad 1^{\circ} \text { lugar - Fazenda Omologi - 259,65 pontos } \\
& 2^{\circ} \text { lugar - Itariri - 254,95 pontos } \\
& \quad 3^{\circ} \text { lugar - Fazenda Arabela - 239,25 pontos } \\
& \text { - } \quad 4^{\circ} \text { lugar - Maria Jape II - 231,00 pontos } \\
& 5^{\circ} \text { lugar - Maria Jape I - 226,05 pontos }
\end{aligned}
$$

\subsubsection{Seleção final}

A etapa posterior, compreendeu a seleção de três sítios onde foram realizadas investigações geotécnicas (sondagens e ensaios de solo), e os respectivos projetos básicos dos aterros sanitários. As três áreas foram submetidas a apreciação pública, através de audiência pública, onde finalmente foi escolhida a área do aterro sanitário (conforme estabelecia o termo de referência do trabalho).

As três áreas selecionadas para a última fase de seleção foram: FAZENDA OMOLOGI (fotos 24 e 25 - pag. 75) ITARIRI (fotos 29 a 31- pag. 83) ; E MARIA JAPEI (foto 28 - pag. 79).

Nota-se novamente que o critério utilizado para a seleção de sitios não considerou os condicionantes físicos, pois o sítio Arabela apresentava melhores condições de permeabilidade de solo ( Nota 10 - de acordo com a hierarquização) e foi descartado apesar de ser classificado em $3^{\circ}$ lugar. O mesmo aconteceu com o sítio Maria Jape II, que foi classificado em $4^{\circ}$ lugar e perdeu seu lugar para Maria Jape 1 , em $5^{\circ}$ lugar. As justificativas atribuídas para a exclusão dos sítios foram as condições precárias de acesso e da ponte sobre o Rio Cachoeira que ficava submersa nas épocas de cheias (foto 27 - pag. 79) .

As três áreas foram reavaliadas e chegou-se a conclusão que o Sítio Maria Jape I também deveria ser excluído pelo mesmo motivo do Maria Jape II. 
Por motivos desconhecidos, no lugar do sítio Maria Jape I entrou como área alternativa, a ałual área de disposição dos residuos, a área do lixâo Cururupe, descartada na primeira fase de seleção por representar o pior sítio para a disposição dos resíduos no município de lihéus.

Com isso, as três áreas escolhidas para a realização de investigações geotécnicas de detalhe foram:

- ALTERNATIVA 1 - OMOLOGI (fotos 24 e 25 - pag. 75)

- ALTERNATIVA 2 - ITARIRI (fotos 29 a 31 - pag. 83)

- ALTERNATIVA 3 - CURURUPE (fotos 22 e 23 - pag. 73)

Investigaçöes geológico-geotécnicas

Em cada sítio foram realizadas seis sondagens a percussão locadas em diferentes cotas topográficas. Foram coletadas amostras e realizados ensaios de permeabilidade "in situ", granulometria e Limite de Liquidez e Plasticidade.

\section{ALTERNATIVA 1 - OMOLOGI}

De acordo com os resultados obtidos, a espessura de solo nas cotas mais baixas varia de 4,8 - 6,8 metros de profundidade. Nas cotas mais elevadas, variam de 8,7 a 21,6 metros.

A cobertura superficial com espessura entre 1 e 3,60 metros, é síltico-arenosa com contribuição de argila. A porcentagem de silte, argila e areia fina (que passa pela peneira 200) varia entre 18 a $38 \%$, o restante é representada por areias grossas e pedregulhos. A permeabilidade deste horizonte é cerca de $2,25 \times 10^{-4} \mathrm{~cm} / \mathrm{s}$.

Abaixo, ocorre um nivel sítico - argiloso intercalado com areia fina, pedregulho e matéria orgânica. A porcentagem de silte, argila e areia fina é $55 \%$. A permeabilidade é de $2,04 \times 10^{-5} \mathrm{~cm} / \mathrm{s}$, condições mais adequadas, para a implantação de aterros sanitários.

A profundidade do nível d'água varia de 15 metros (nas cotas mais altas) a 3,0 metros junto aos fundos de vales.

Foi estimado um volume na ordem de $700.000 \mathrm{~m}^{3}$ de solo disponivel para cobertura dos residuos.

\section{ALTERNATIVA 2 - ITARIRI}

O manto de intemperismo na área apresenta uma distribuição bastante irregular, com profundidade que varia de 3 a 11 metros. Esta irregularidade é atribuída à presença de blocos de esfoliação esferoidal imersos no solo. 
O horizonte superior apresenta textura sitto argilosa com presença de areia fina a média, e pouca matéria orgânica. A compacidade varia entre baixa a intermediária (SPT varia de 2 a 6 golpes).

O horizonte intermediário, com espessura que varia de 1 a 6 metros, a porcentagem de silte e argila é de 65 a $80 \%$, o restante é contribuição de areia e pedregulho.

O inferior é marcado pelo contato brusco com a rocha alterada. É composto principalmente por material sítico - arenoso e pedregulhos. A porcentagem de silte e argila varia entre 40 a $70 \%$. Há um aumento na concentração de pedregulhos nos níveis mais profundos do manto de intemperismo.

Entre a profundidade de 2 a 3 metros, o coeficiente de permeabilidade variou entre $10^{5}$ a $10^{-4} \mathrm{~cm} / \mathrm{s}$.

Nas meias encostas do anfiteatro, o nível da água foi detectado na profundidade de 9 metros.

Foi estimado um volume na ordem de $350.000 \mathrm{~m}^{3}$ de solo para cobertura dos resíduos. A cubagem não considerou a possibilidade de ocorrência matacões imersos no manto de intemperismo.

\section{ALTERNATIVA 3 - CURURUPE}

As sondagens executadas abrangeram a porção mais rebaixada da área (a planicie aluvionar), onde são lançados os resíduos, e os morros testemunhos da Formação Barreiras.

Na planície aluvionar, o horizonte superior é pouco a medianamente compacto (SPT de 3 a 10 golpes), apresentando 2,50 metros de espessura de areia fina a média sittosa. O horizonte subsequente (2,45 a 7,00 metros), é composto por niveis de material argilo-siltoso e silto-argiloso, ambos com areia fina a média, coloração cinza clara e variegada, respectivamente. A compacidade é predominantemente fofa e consistência mole, com SPT variando de 3 a 6 golpes. A permeabilidade é da ordem de $2,65 \times 10^{-5} \mathrm{~cm} / \mathrm{s}$, na sua parte mais baixa.

$\mathrm{Na}$ transição entre a planicie aluvionar e os morros testemunhos, o horizonte superficial, com 4 metros de espessura é formado por areia fina a média, siltosa, cor marrom escura, pouco compacta (SPT de 3 a 5 golpes), com coeficiente de permeabilidade na ordem de $3,50 \times 10^{-3} \mathrm{~cm} / \mathrm{s}$. O nivel d'água foi detectado a 2,10 metros de profundidade.

Nos morros testemunhos a espessura do manto de intemperismo varia entre 13 a 18 metros. É constituído por niveis síltico-arenosos, síltico-argilosos, argila siltosa e matéria orgânica. A compacidade varia de mole a rija (próximo ao contato com a rocha alterada). O nível d'água foi detectado entre 13 a 16 metros de profundidade. 
Foi estimado um volume superior a $1.000 .000 \mathrm{~m}^{3}$ de solo disponivel para cobertura diária de residuos.

\subsubsection{Escolha Final do Sítio}

Sob o aspecto hidrológico, as áreas Omologi e Itariri foram consideradas semelhantes, com a circulação das águas subterrâneas condicionadas pelo topo do embasamento rochoso, que se apresenta pouco fraturado e com baixa permeabilidade. A área do Cururupe, inserida em ambiente fluvial, foi considerada como de maior potencialidade de contaminação das águas superficiais e subterrâneas.

As condições topográficas das áreas Omologi e Itariri foram consideradas adequadas para a implantação de aterros, justificadas pelas diferenças de cotas topográficas dos terrenos que favorecem o escoamento dos líquidos percolados por gravidade. A área Cururupe, ao contrário, devido a topografia plana, foi considerada problemática para a drenagem destes líquidos.

Os índices de permeabilidade do solo nas áreas Omologi e Itariri são equivalentes, e encontram-se em torno do limite superior recomendado $\left(10^{-5} \mathrm{~cm} / \mathrm{s}\right)$. Na área Cururupe os valores de permeabilidade são bastante variados, sugerindo haver muita heterogeneidade no substrato.

As áreas Omologi e Cururupe apresentam major disponibilidade de solo para a cobertura dos residuos, suficientes para atender toda a vida útil do aterro. Na área Itariri, a disponibilidade de solo foi considerada limitada e insuficiente para atender a demanda prevista.

Em relação aos aspectos bióticos, a área Itariri foi avaliada como mais preservada em relação a Omologi, apresentando maior densidade de capoeiras, brejos e cabrucas $\mathrm{A}$ área do Cururupe foi qualificada como desfavorável, por estar sobre terrenos encharcados, próxima de mangue e da praia. O acúmulo de resíduos existente no local já constitui um foco de contaminação e de vetores patogênicos, sendo premente sua recuperação

Do ponto de vista do meio antrópico, a definição da melhor alternativa deveria levar em consideração que lthéus foi escolhida pelo Estado da Bahia, como uma cidade potencial para o desenvolvimento do turismo. Nesse sentido, qualquer impacto ambiental que possa interferir nessa diretriz estratégica deveria ser, evidentemente evitado.

Assim, a área do ấual lixão do Cururupe e a ltariri estariam prejudicando os seus condicionantes de uso do solo, face a presença de elementos da paisagem inerentes à região de turismo. Portanto, a Área Omologi foi a indicada para primeiro lugar. 


\subsubsection{Resultado Final}

De acordo com a avaliação final das alternativas Omologi , Itariri e Cururupe, foi unânime a exclusão da área do Cururupe para o futuro aterro.

Quanto ao meio físico, a área Omologi foi a mais indicada por apresentar maior disponibilidade de áreas de empréstimo. Em relação ao meio biótico, a Omologi foi também considerada a mais favorável por estar mais degradada em relação a Itariri. Quanto aos critérios antrópicos, a Itariri também foi descartada por estar inserida numa região de interesse para o desenvolvimento do turismo, restando portanto somente a área Omologi.

Com isso, a área indicada pela equipe técnica multidisciplinar do estudo foi a Fazenda Omologi.

Posteriormente, as três áreas alternativas foram discutidas com a comunidade interessada, através de Audiência Pública.

Esta Audiência Pública decidiu recomendar a área Itariri para implantação do aterro sanitário, descartando a Fazenda Omologi. A justificativa para tal resolução foi a distância da área Omologi em relação a porção Sul da cidade.

Assim a área selecionada seguiu a decisão desta audiência, e o sítio selecionado para o recebimento do aterro sanitário de lihéus foi o Itariri.

Posteriormente a sua escolha, não foram realizadas investigações geológicas mais detathadas que pudessem avaliar a potencialidade de contaminação das águas subterrâneas, nem como do real volume de solo disponivel para cobertura de solos, pois conforme mencionado acima, estima-se que a espessura é bastante heterogênea, comprovada pela ocorrência de matacões de esfoliação esferoidal disperso ao longo das vertentes dos anfiteatros (foto 30 - pag. 83 ) 
Vasconcelos a Leste; Ribeirão Pires, Mauá, Santo André, Diadema e São Bernardo do Campo a Sudeste; Santos a Sul; Embú Guaçu e ltapecerica da Serra, a Sudoeste; Embú, Taboão da Serra, Jandira e Osasco a Oeste; Santana do Parnaíba e Cajamar a Noroeste (figura 3.11).

Possui a maior densidade populacional do país, que em 1996 atingia 9,839 milhões de habitantes (http://www.prodam.sp.gov.br). É recorde em produção de residuos domésticos/urbanos, produzindo atualmente cerca de 12.000 toneladas diárias. Os resíduos urbanos são compostos essencialmente por matéria orgânica $(49,5 \%)$, plásticos $(22,9 \%)$, papel/papelão $(18,8 \%)$, e metais $(2,9 \%)$, Orth e Motta (1998).

Os resíduos urbanos são encaminhados para dois aterros sanitários, Bandeirantes e o São João ou Sítio São João .

O Aterro Bandeirantes funciona desde 1979. Era operado na forma de lixão, recebendo resíduos de origens diversas. Localiza-se junto à Rodovia dos Bandeirantes, no Bairro de Perus, na zona norte da capital. Atualmente recebe praticamente a metade dos resíduos recolhidos pelo serviço municipal de coleta regular (5.500 t/dia), e alguns típos de resíduos sólidos industriais da classe 2 e 3 . Estima-se uma vida útil de somente mais 2 anos para o aterro.

O Aterro São João recebeu licença ambiental em 1991 e entrou em operação em dezembro de 1992. Situa-se na zona Sudeste da capital, no final da estrada de Sapopemba, junto ao limite com o município de Mauá. Recebe cerca de 6.000 toneladas diárias de residuos recoinidos pelo serviço municipal. Foi selecionado para exemplificar um estudo de caso na presente dissertação devido as suas características construtivas e operacionais, .

\subsubsection{Geologia}

O quadro geológico do município de São Paulo é compartimentado em três conjuntos litoestratigráficos maiores (figura 3.12).

Rochas metamórficas de origem sedimentar e vulcânica, com intrusões graníticas e pegmaḱticas, de idades desde o Proterozóico Inferior ao Neoproterozóico, representam o primeiro e mais expressivo conjunto litológico, genericamente referido como embasamento cristalino. É representado principalmente por rochas metamónficas dos Grupos São Roque e Serra do laberaba e suites graníticas indiferenciadas (IPT 1981a). Filitos, metarenitos quartzitos e xistos porfiroblásticos são os componentes principais do Grupo São Roque, seguidos por intercalações lenticulares de anfibolitos, metacalcários dolomitos e rochas calciossilicatadas. Intrusões graníticas são freqüentes.

O segundo corresponde às rochas sedimentares clásticas, de granulação grossa a fina, associadas à Bacia de São Paulo de idade cenozóica, que ocupam predominantemente a região central do município. São representadas por arenitos de variada granulometria, mal selecionados e argilitos com intercalações arenosas e siltosas, atingindo espessuras de várias centenas de metros. 


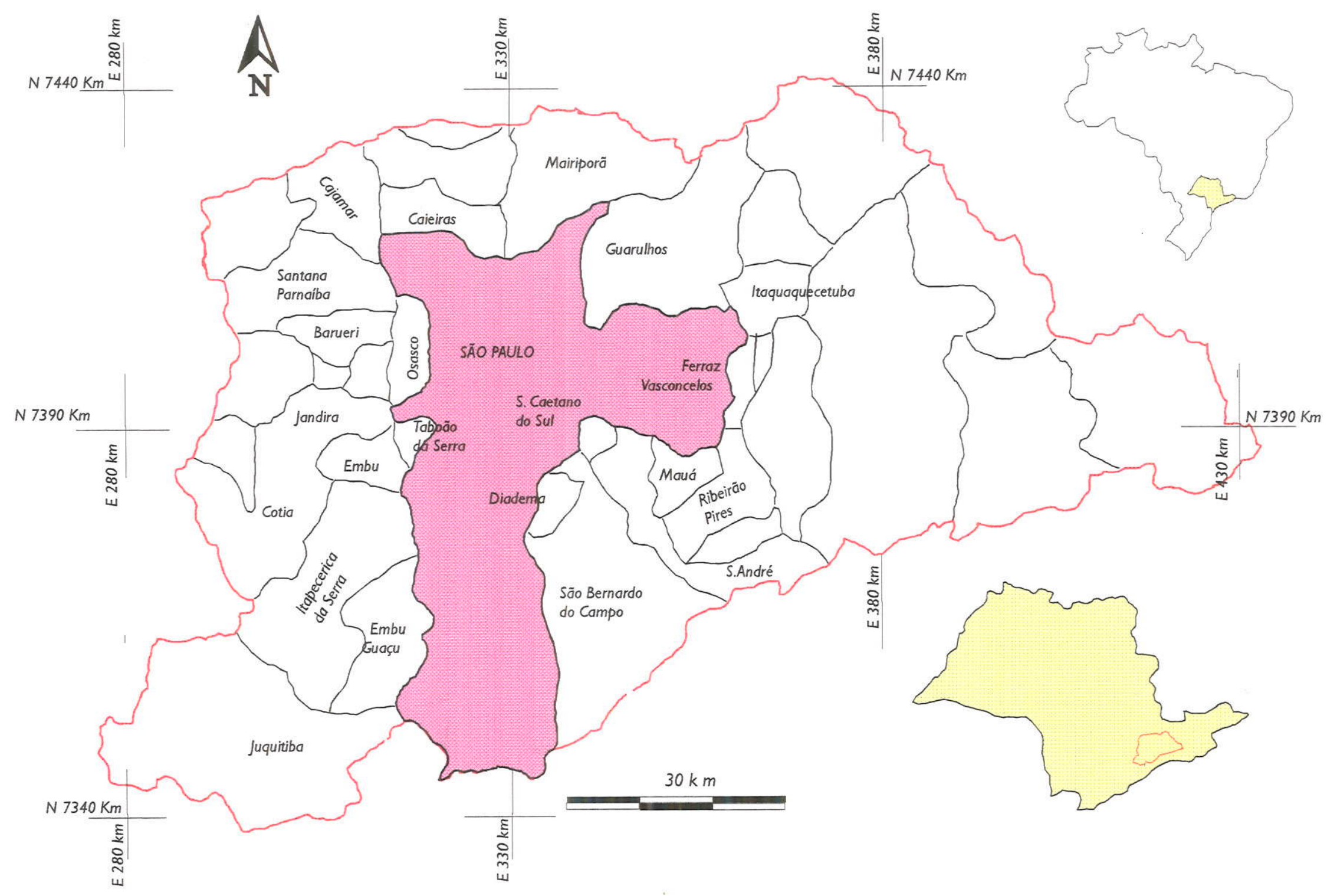

Figura 3.I I - Localização geral do Município de São Paulo, SP. 
Estas rochas sedimentares preenchem zonas deprimidas e formam testemunhos sobre o embasamento metamórfico.

O terceiro é formado por sedimentos aluvionares relativos a instalação da rede de drenagem atual, de idade quaternária (Coutinho, 1979 e 1980). Apresentam sua maior expressão em área no setor central e centro sul do município, ocorrendo de forma irregular ao longo dos talvegues de ramos principais da rede de drenagem. Predominam areias argilosas, mal estruturadas e pouco selecionadas a bem selecionadas, de coloração ocre, cinza escuro a negras, com espessuras muito variadas, desde alguns centímetros a dezenas de metros.

O setor sul do município é dominado pelo conjunto de rochas metamórficas, com testemunhos isolados de rochas sedimentares terciárias e intrusões graníticas indiferenciadas. Predominam xistos, filitos, migmał́itos e gnaisses com intercalações de quarztitos, anfilbolitos e rochas calciossilicatadas correspondentes ao Complexo Embú. Este diferenciamse do Grupo São Roque principalmente pelo grau de metamorfismo mais elevado.

Os principais traços estruturais do município de São Paulo, seguindo as feições estruturais de expressão continental do sudeste brasileiro, são as zonas de cisalhamento e zonas rúpteis orientadas segundo ENE, como as falhas de Jundiuvira, Taxaquara, Jaguari, Parateí e Cubatão, originadas durante o Proterozóico e reativadas no Cenozóico, onde condicionaram a sedimentação das bacias de São Paulo e Taubaté (Coutinho 1979 e 1980).

Estas zonas de cisalhamento separam as unidades pré-cambrianas em blocos tectônicos. O setor norte, ocupado pelo Grupo São Roque, tem seu limite sul com o Complexo Embú marcado pelo sistema de falhas de Taxaquara e Jaguari. O Complexo Embú, por sua vez, é limitado a sul com o Complexo Costeiro, através da falha de Cubatão, fora dos limites do município de São Paulo. Estas falhas possuem caráter dominantemente dúctil e transcorrente, com zonas de cisalhamento de até várias centenas de metros de espessura, englobando milonitos, blastomilonitos, filonitos e brechas tectônicas (IPT,1981a e Hasui e Oliveira, 1984).

Nas rochas metamórficas, de modo geral, a estrutura mais penetrativa corresponde ao bandamento metamórfico e xistosidade, intensamente dobrados, com superfícies complexas e eixos de direção oscilando em torno de ENE.

As intrusões graníticas, de natureza tardi a pós-tectônica, exibem foliação nas bordas e sistemas de fraturas relacionadas à tectônica de reativação jurássica e fraturas de resfriamento.

\subsubsection{Geomorrologia}

O município de São Paulo está inserido no Planalto Atlântico (Almeida 1964), mais especificamente na zona que constitui o chamado Planalto Paulistano de Ab'Saber (1957), adotado também no mapa geomorfológico do Estado de São Paulo (IPT 1981b). 


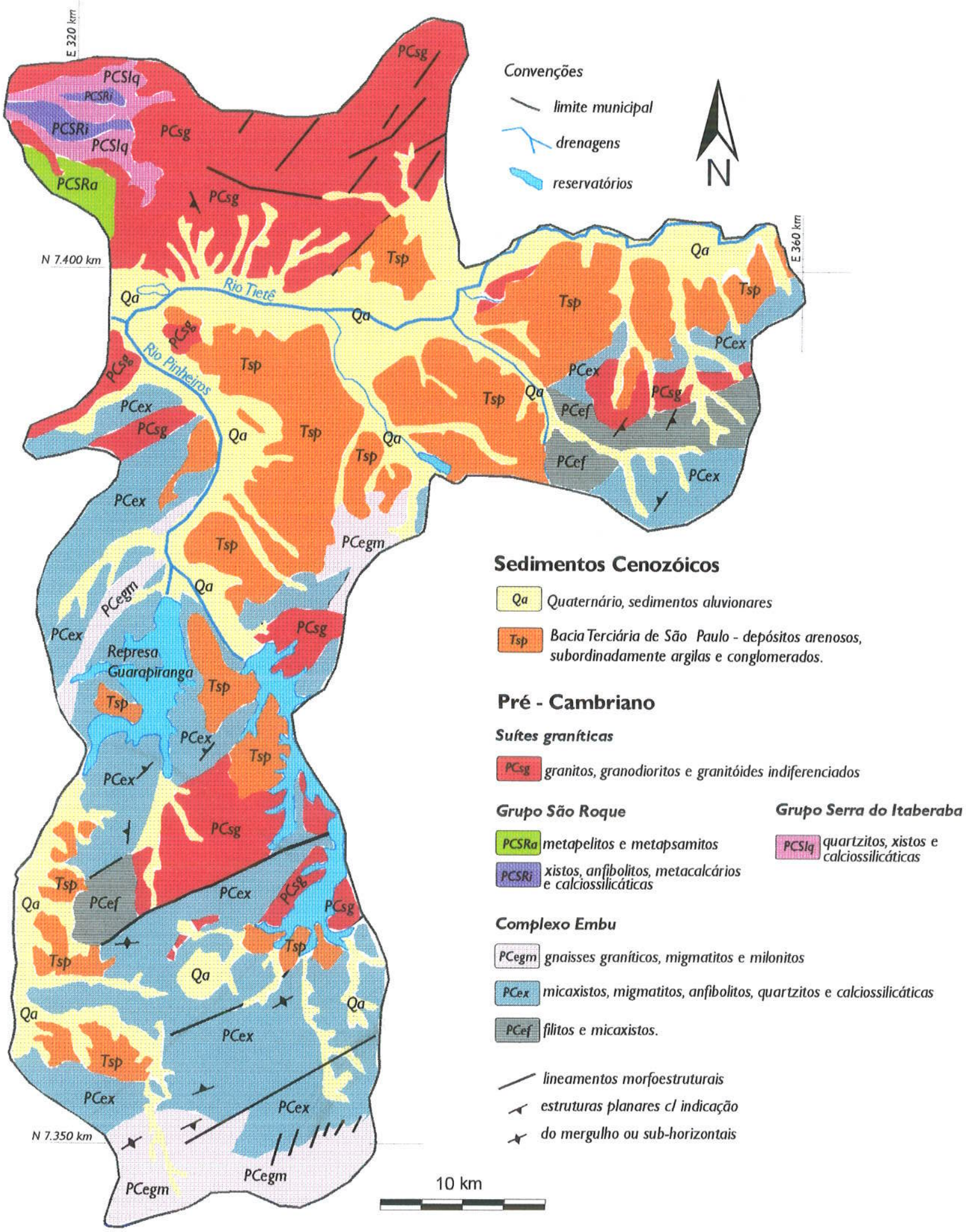

\section{Figura 3.I2 - Geologia do Município de São Paulo,SP. (adaptado de Rodriguez, 1998)}


A compartimentação geomorfológica e topográfica do Planalto Paulistano segue, a grosso modo, as unidades litológicas. Desta maneira, três unidades geomorfológicas principais são reconhecidas.

Nos setores Norte, Noroeste e Sul do município, o embasamento metamórfico sustenta relevo de morrotes baixos, morrotes alongados e morros, com declividades médias (entre 15 a $30 \%$ ), que passam a morros com serras restritas e serras alongadas com escarpas e declividade média a alta (15 a 45\%), representando principalmente as intrusões graniticas (Serra do Tico-Tico) e lentes de quartzito (como o morro do Jaraguá). O aterro São João está inserido no contexto de morros e morrotes do setor noroeste do município.

$\mathrm{Na}$ região central do município domina o relevo de colinas, caracterizado por baixas declividades, desenvolvido sobre sedimentos da Bacia de São Paulo. Localmente ocorrem espigões devido a presença de carapaças ferruginosas (lateriticas), como o espigão central de São Paulo.

Por último, os sedimentos aluvionares quaternários correspondem a unidade morfológica das planícies aluviais que acompanham a rede de drenagem atual, como dos rios Tietê e Pinheiros. Representam áreas planas a suavemente onduladas, sujeitas a inundações periódicas.

\subsubsection{Cobertura Superficial}

O manto de intemperismo que recobre São Paulo encontra-se extremamente descaracterizado em relação às suas condições naturais, devido ao intenso processo de urbanização ocorrido no municipio. Encontra-se quase que em sua totalidade impermeabilizado, restando poucos remanescentes de solo exposto, principalmente junto aos limites Noroeste e Norte, e ao longo dos terrenos protegidos por lei, como as bacias contribuintes da Represa Billings e Guarapiranga, Mata da Cantareira e Parque do Estado (figura 3.13).

De modo geral, a espessura e a composição do manto de intemperismo varia de acordo com a composição química e mineralógica das rochas de origem, e do tipo de relevo incidente. A espessura do manto geraimente acompanha as declividades das encostas, chegando a ausentarse nas áreas mais íngremes (declividades superiores a 45\%), expondo rocha.

As planícies aluvionares são representadas pelos sedimentos aluvionares inconsolidados e pelos solos hidromórficos.

Os relevos de colinas e morros da Formação São Paulo são recobertos por uma cobertura de solo laterizado (presença de materiais cimentantes de alumínio e ferro), de granulometria argiloarenosa, não estruturado, tonalidades avermelhadas, e com espessura na ordem de 3 metros, podendo atingir 8 metros. Sotoposto, incide um horizonte constituido por camadas e lentes intercaladas de areias e argilas, com espessura bastante variável. Foram identificados quatro 
niveis, denominados argilas vermelhas rijas, solos variegados, argilas duras cinza-esverdeado e areias basais (Massad, 1980).

Nos relevos esculpidos sobre rochas xistosas, o solo superficial geralmente não ultrapassa a 1,5 metros de espessura, enquanto que o solo de alteração pode apresentar algumas dezenas de metros, com a nítida presença da estrutura foliada ainda preservada da rocha de origem.

Nos granitos e granitóides, o solo é geralmente argilo-arenoso com espessura variável, sendo comum a presença de grandes matacões imersos no solo ou em superfície.

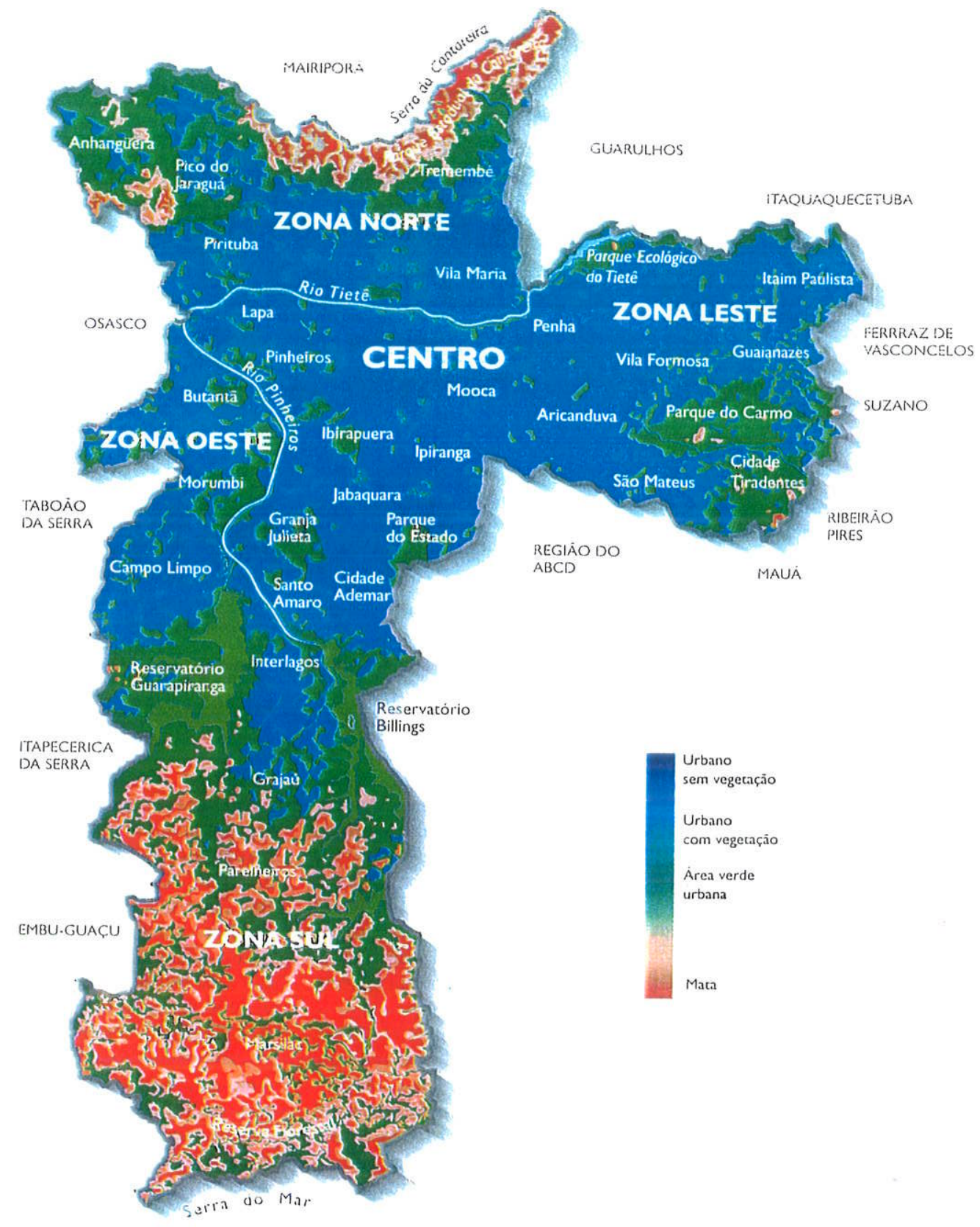

Figura 3.13 - Distribuição da ocupação no Município de São Paulo (SP).Obtido em www.prodam.sp.gov.br/svma/atlasamb/index.htm) 


\subsubsection{Clima}

De acordo com a classificação de Köppen, o município de São Paulo está inserido no clima mesotérmico de inverno seco, onde a temperatura do mês mais quente não atinge $22^{\circ} \mathrm{C}$. Os totais pluviométricos anuais variam entre 1.300 e $1.700 \mathrm{~mm}$. O mês mais seco e frio é julho, com temperaturas médias em torno de $16,5^{\circ} \mathrm{C}$. A estação seca se estende de maio a setembro. $\mathrm{O}$ mês mais chuvoso é janeiro.

A pluviosidade anual média entre 1980 e 1998 foi de $1346 \mathrm{~mm}$, com meses menos chuvosos entre junho e agosto, e mais chuvosos entre dezembro a março. A temperatura média anual no mesmo período foi de $19^{\circ} \mathrm{C}$ (http:// www.prodam.sp.gov.br).

\subsubsection{Processo de seleção do aterro São João}

No contexto dos estudos de casos, o Sítio São João foi escolhido por se tratar de um dos aterros mais antigos do Brasil que foi projetado, implantado e operado, desde o início, como aterro sanitário, além do fato de tratar-se do maior aterro sanitário do estado, e com expressão mundial.

\subsubsection{Histórico da pesquisa de sítios no município}

$\mathrm{Na}$ RMSP as primeiras preocupações em relação a áreas de disposição de resíduos surgiram na década de setenta, quando foi desenvolvido o estudo Programa para a Disposição Final dos Resíduos Sólidos do Município de São Paulo, realizado pela Serete Engenharia S.A em 1977.

O desenvolvimento deste estudo refletia a situação crítica da RMSP, que foi criada (Lei Complementar Federal 14/73) decorrente da expansão da capital paulista em direção aos municípios do seu entorno, principalmente aqueles situados no denominado ABCD paulista (figura 3.11- pag. 95). A proximidade física desses municípios e o expressivo crescimento que ocorreu no final da década de cinqüenta e início da década de sessenta, decorrente da instalação de empresas montadoras de veículos, fizeram com que esses municípios começassem a ter problemas sérios de infra-estrutura, principalmente no caso da disposição dos resíduos sólidos. No caso do município de São Paulo, a população praticamente triplicou entre o fim das décadas de cinquenta e setenta, passando de 2,198 para 5,924 milhões de habitantes respectivamente (http:prodam.sp.gov.br).

Esse estudo, além de avaliar outras alternativas para o destino dos resíduos gerados no município, contemplou a seleção de áreas para a disposição final dos resíduos sólidos (Limpurb/Equipe Umah, 1990). Através de análises cartográficas foram delimitadas 100 (cem) áreas potenciais passíveis de utilização como aterros.

Através de inspeções de campo e sobrevôos de helicóptero, foram descartadas 57 (cinqüenta e sete) áreas devido principalmente a ocupação urbana incidente e/ou vizinhança próxima; área útil insatisfatória e péssimas condições de acesso. 
O restante das áreas (que totalizavam 43) foram analisadas de acordo com os seguintes parâmetros: caracierística do relevo, dimensão das bacias hidrográficas; condiçóes de acesso, uso e ocupação do solo e legislação vigente.

As áreas que se mostraram com aptidão favorável, conforme os parâmetros supracitados, corresponderam somente a 16. As demais foram descartadas principalmente por incidirem em regiôes com ocupações concretizadas ou em expansão, ou porque encontravam-se inseridas em APMs (Área de Proteção aos Mananciais - de acordo com a Lei N 1172/76 , § 25).

Esse estudo resultou na implantação dos aterros de Sapopemba e de São Mateus (Fazenda do Carmo). Para as demais áreas foram recomendadas suas desapropriações.

O periodo posterior a realização deste estudo foi marcado pela implementação de inúmeras leis, decretos e normas técnicas, que abrangeram direta e/ou indiretamente a disciplina do armazenamento, transporte e disposição dos resíduos sólidos.

Como exemplo, das normas técnicas que surgiram, destacam-se a NBR 8849/1985, que fixou condições mínimas exigiveis para a apresentação de projetos de aterros controlados de resíduos sólidos urbanos e a NB 843/1985 que fixou condições mínimas exigiveis para a apresentaçäo de projetos de aterro sanitário de resíduos sólidos urbanos. A NBR 10004/1987 classificou os residuos quanto aos seus riscos potenciais ao meio ambiente.

Dentre as leis que surgiram neste periodo destacam-se a Portaria Minter $\mathrm{N}^{\circ} 53$, de 01/03/79 que estabeleceu normas ao projeto especifico de tratamento e disposição de resíduos sólidos; a Lei $N^{\circ} 7.347$, de 24/07/85 que disciplinou a ação civil pública de responsabilidade por danos causados ao meio ambiente, ao consumidor, a bens e direitos de valor artístico, estético, histórico, turístico e paisagístico; a Resolução Conama $N^{\circ}$ 001, de 23/01/86 que define Impacto Ambiental e obriga a elaboração de Estudos de Impacto Ambiental (ElA/RIMA) para as atividades modificadoras do meio ambiente, inclusive as áreas de disposição de residuos; e a Resolução Conama $N^{\circ} 005$ de 15/06/88 que obriga o licenciamento ambiental de obras do sistema de limpeza urbana.

Em 1989, os aterros de Sapobemba e de São Mateus (indicados pelo estudo de 1977) foram fechados por pressão popular e pelas suas capacidades limitadas. Por motivos desconhecidos, as áreas indicadas nestes estudos não foram desapropriadas e portanto não preservadas para essa finalidade. Nesta época a população superava 9,5 milhões de habitantes que geravam cerca de 6.000 toneladas de resíduos diariamente (www.ibgc.com.br).

Em função do fechamento destes sítios, em 1990, a prefeitura elaborou um novo estudo visando a seleção de áreas, pois a urbanização ocorrida neste período principalmente na região periférica do município, excluiu todas as áreas indicadas como potenciais no estudo realizado em 1977. 
Este estudo denominado de Parecer sobre a Situação dos Aterros Sanitários do Município de São Paulo foi elaborado pela Secretaria de Serviços e Obras e LIMPURB da Prefeitura Municipal (PMSP/SSO/LIMPURB, 1990).

Foram prospectadas áreas principalmente no extremo Leste do município. A pesquisa restringiu-se nas áreas de uso rural, ou aquelas que não estavam totalmente comprometidas com o uso urbano. Foram excluídos do processo de seleção os terrenos protegidos através da Lei de Proteção aos Mananciais (Artigo 25 da Lei 1172/76) inseridos nas bacias dos reservatórios Billings e Guarapiranga no quadrante Sul, e a área de drenagem dos reservatórios Cabuçu e Engordador, no quadrante Norte.

Na etapa posterior foram selecionados os sítios que apresentaram menor grau de rejeição por parte da população, vida útil igual ou superior a 5 anos (considerando 3.000 toneladas diárias), menores distâncias e custos de implantação e operação. Esta pesquisa resultou na delimitação de 7 sitios.

Após o término destes estudos, no final de 1990, a prefeitura elaborou um edital de concorrência, que teve como objetivo a contratação de uma empresa de consultoria para analisar dentre os sete sítios selecionados a melhor alternativa para a implantação do aterro sanitário.

Em dezembro de 1992, entra em operação o Aterro Sanitário da Zona Leste, selecionado e licenciado para receber parcela dos resíduos urbanos gerados pelo bairros inseridos no quadrante Leste do município de São Paulo, que posteriormente passou a se chamar de Aterro Sanitário São João.

\subsubsection{Método utilizado para a seleção de sítios}

O processo de seleção de sítios para a implantação do aterro sanitário São João teve como base as sete áreas indicadas pela prefeitura, coniorme mencionado acima. Estavam inseridas praticamente todas na zona Leste do municipio, próximas aos limiłes de Mauá e Ferraz. de Vasconcelos, com exceção do Sítio Pedreira Aidar, na zona Norte, próxima ao limite com Guarulhos.

A partir da localização geográfica destas áreas foi realizada uma análise da drenagem superficial da região em geral, inserida integralmente na bacia do rio Tietê. Paralelamente foram analisadas as principais condições de acesso, o zoneamento urbano e as diretrizes do plano diretor municipal.

Esta análise integrada dos sítios resultou no agrupamento de três conjuntos denominados de Grupo da $3^{\circ}$ Divisão, Grupo Santa Etelvina e Grupo Fernão Dias (figura 3.14).

O Grupo da $3^{\circ}$ Divisão, englobou os sitios: Minami, Ribeirão Verde, Floresta e São João. Estão situados todos na bacia hidrográfica do rio Aricanduva, e suas principais vias de acesso são pela Estrada de Sapopemba e pela Avenida Aricanduva/Estrada da $3^{a}$ Divisão. 
O Grupo Santa Etelvina, englobou os sítios Conceição e Pedrinhas. Estão inseridos na Bacia do Ribeirão Itaquera, e as principais vias de acesso são pela Avenida Aricanduva e a Estrada do Iguatemi (figura 3.14).

O Grupo Fernão Dias foi representado pelo sítio Pedreira Aidar, situado próximo a divisa com Guarulhos. Está inserido na bacia do rio Cabuçu de Cima, e o acesso principal é pela Rodovia Fernão Dias.

Para a análise de cada sítio foi definida uma área de influência da ordem de 1.000 metros do contorno externo das áreas indicadas. A justificativa para a adoção deste limite foi de que os principais impactos ambientais adversos decorrente da implantação e operação do aterro ocorreriam neste intervalo geográfico. Foram analisados os meios físico, biótico e sócio econômico.

Para cada impacto ambiental diagnosticado foi simulado o grau de sua intensidade e o ambiente decorrente da implantação e operação do aterro saniłário. Os impactos foram graduados em grande, moderado, pequeno e mínimo.

Em relação ao meio físico, os impactos considerados significantes na escolha do sítio foram a poluição dos recursos hídricos, poluição do ar e movimento de terra .

A poluição dos recursos hídricos foi definida como a poluição que ocorre nos corpos de águas superficiais e subterrâneas. A intensidade do impacto foi considerada grande quando havia presença de cursos de água e/ou nível da água aflorante. Moderado, na presença de curso d'água intermitente Pequeno, quando havia possibilidade do aterro atingir somente os cursos d'água de jusante. Não foi registrado situação de impacto mínimo em relação aos recursos hídricos. Nos dias de hoje, com o aumento do grau de exigências por parte dos órgãos ambientais, não seria aceita em hipótese alguma, a atribuição de impacto mínimo no caso de risco de poluição das drenagens a jusante, pois trata-se de um dos principais problemas da operação de aterros sanitários.

O movimento de terra foi definido como o impacto decorrente da necessidade de obtenção de material (solo) para impermeabilização e cobertura de resíduos. O impacto foi considerado grande quando haveria necessidade de extrair material em áreas de empréstimo fora do sítio, e em áreas não degradadas. Impacto moderado, na mesma situação, no enłanto, em áreas já degradadas. Pequeno, quando haveria disponibilidade parcial de material no local do aterro. Mínimo, no caso da existência de material na área do aterro suficiente para toda a sua vida útil.

A poluição do ar e os demais impactos que determinaram o pré - selecionamento da área do aterro estão listados na tabela 3.6 . 


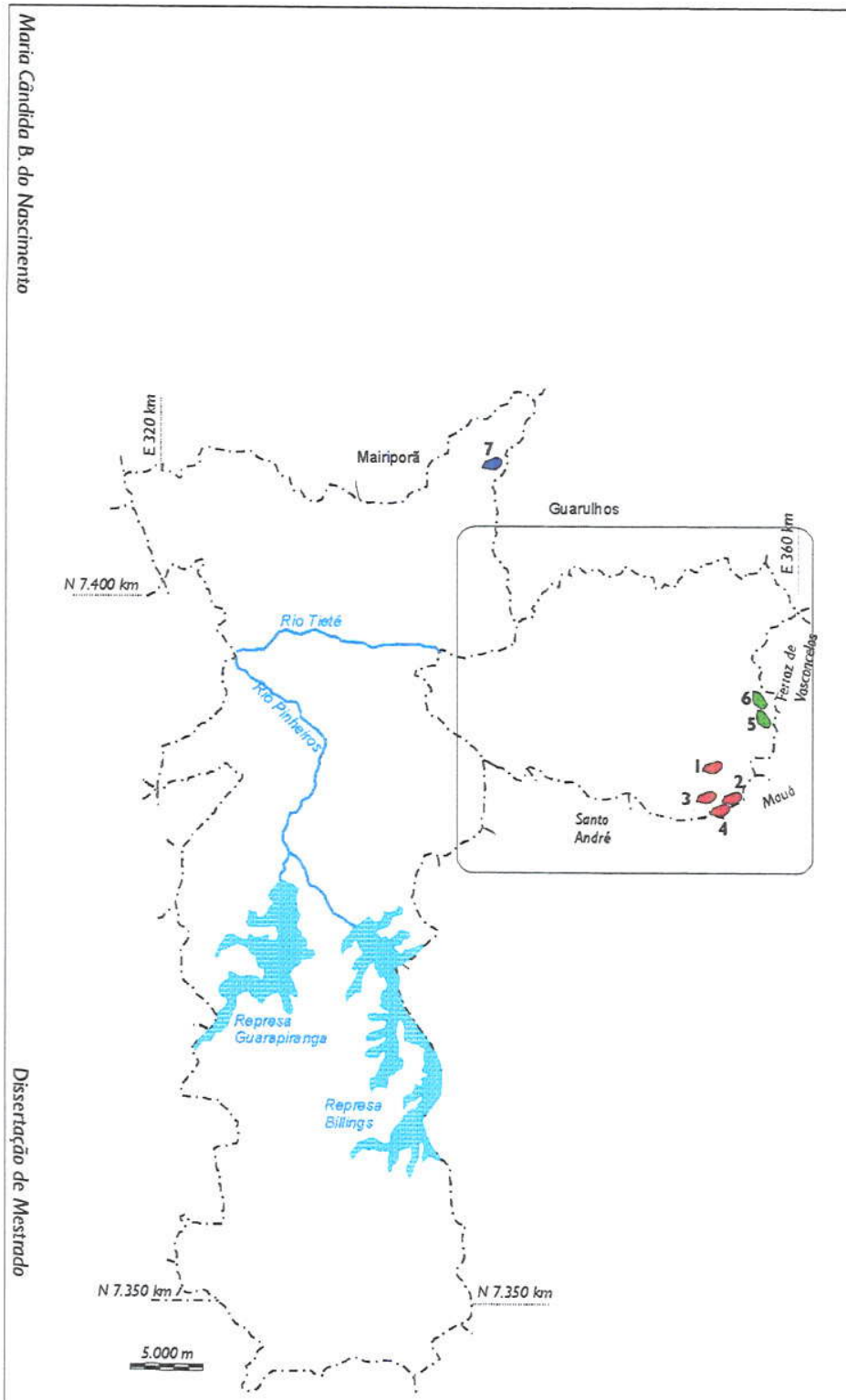

Convençōes

- linha de drenagem

limite da bacia do Rio Aricanduva

limite da Area de Proteção dos Mananciais

- limite municipal

sede municipal

- bairro da cidade de São Paulo

$N$

SITIOS ANALISADOS

Grupo $3^{\circ}$ Divisão

Minami

2 Ribeirão Verde

3 Floresto

4 São João

Grupo Santa Etelvina

5 Minami

6 Ribeirão Verde

Grupo Fernão Dias

7 Pedreira Aidar

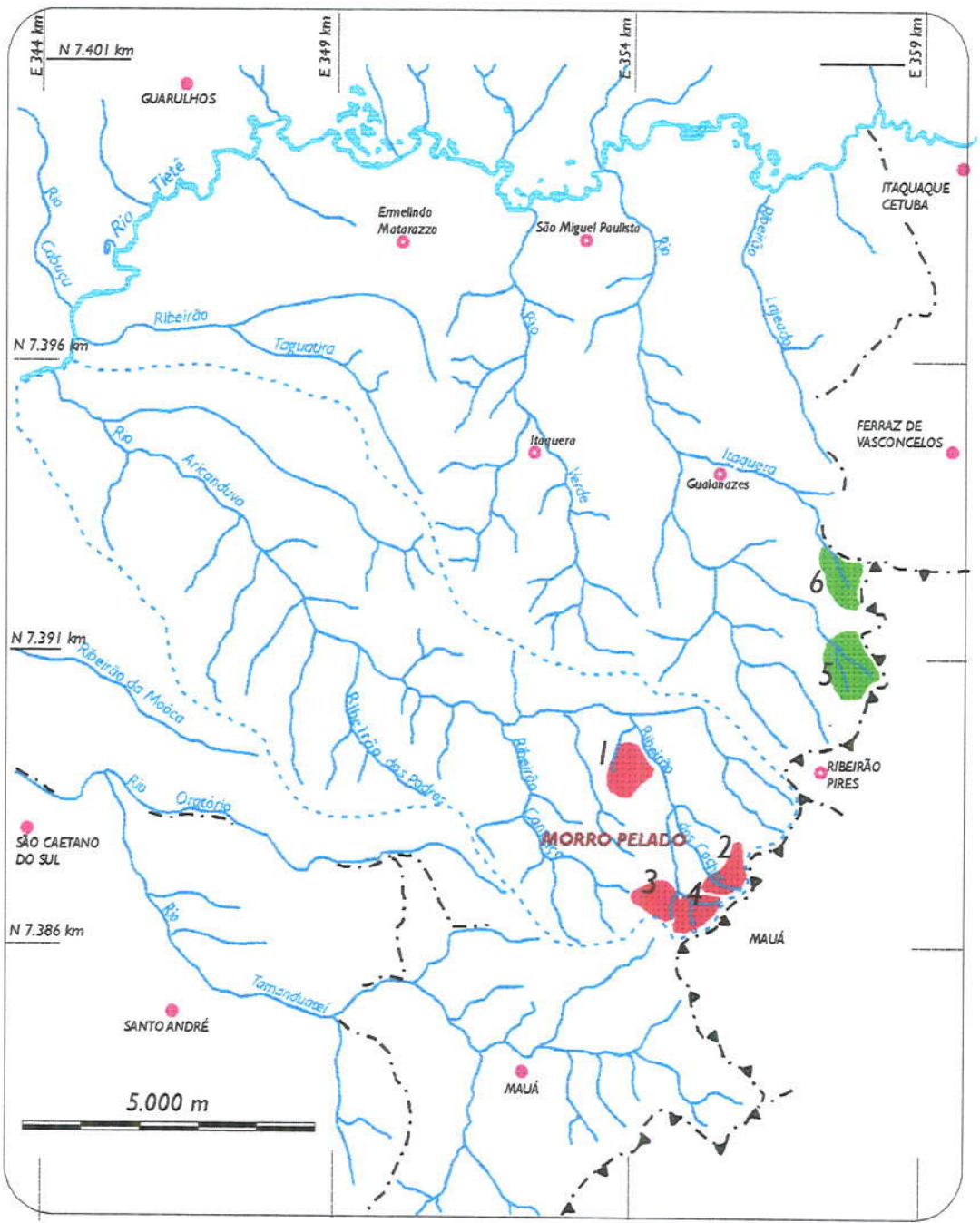

Figura 3.I4 - Localização dos sítios analisados no Município de São Paulo, SP. (adaptado de LIMPURB/Equipe Umah, 1990) 


\begin{tabular}{|c|c|c|c|c|c|c|}
\hline \multirow{2}{*}{$\frac{\mathrm{O}}{\mathrm{HI}}$} & \multirow[b]{2}{*}{ IMPACTO } & \multirow[b]{2}{*}{ DESCRIÇÃO } & \multicolumn{4}{|c|}{ GRADUAÇÃO } \\
\hline & & & GRANDE & MODERADO & PEQUENO & MÍNIMO \\
\hline \multirow{3}{*}{$\frac{0}{\frac{0}{6}}$} & $\begin{array}{l}\text { poluiçāo dos } \\
\text { recursos hidricos }\end{array}$ & $\begin{array}{l}\text { poluição de corpos de água superficiais e } \\
\text { subterrâneos. }\end{array}$ & $\begin{array}{l}\text { presença de cursos d'água } \\
\text { ejou tençol aflorante na área }\end{array}$ & $\begin{array}{l}\text { presença de curso de água intermitente } \\
\text { náa área }\end{array}$ & $\begin{array}{l}\text { possibilidade de poluição } \\
\text { apenas de curso de água de } \\
\text { jusante }\end{array}$ & - \\
\hline & $\begin{array}{l}\text { poluição } \\
\text { do ar }\end{array}$ & $\begin{array}{l}\text { emissāo de material particulado decorrente do } \\
\text { tráfego de caminhōes em estradas não } \\
\text { pavimentadas. }\end{array}$ & $\begin{array}{l}\text { trảifego por estradas não } \\
\text { pavimentadas, cujia utilização é } \\
\text { pequena }\end{array}$ & $\begin{array}{l}\text { tráfego por estradas não pavimentadas } \\
\text { já utilizadas atualmente por caminhões } \\
\text { pesados. }\end{array}$ & postine & $\begin{array}{l}\text { tráfego } \\
\text { unicamente por } \\
\text { vias asfaltadas. }\end{array}$ \\
\hline & $\begin{array}{l}\text { movimento } \\
\text { de } \\
\text { terra }\end{array}$ & $\begin{array}{l}\text { impacto provocado pela movimentaçăo de terra em } \\
\text { locais diferentes da área do aterro para obtenção } \\
\text { de material para impermeabilização e cobertura } \\
\text { dos resíduos. }\end{array}$ & $\begin{array}{l}\text { área de empréstimo externa ao } \\
\text { local, em regiāo não } \\
\text { degradada. }\end{array}$ & $\begin{array}{l}\text { área de empréstimo externa ao local, } \\
\text { em regiăo degradada }\end{array}$ & 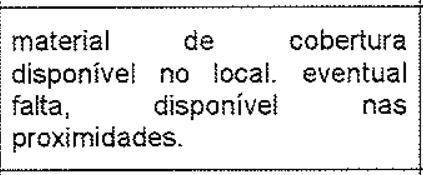 & $\begin{array}{ll}\text { material } & \text { de } \\
\text { cobertura } & \\
\text { seguramente } \\
\text { disponivel no } \\
\text { local. }\end{array}$ \\
\hline \multirow{2}{*}{$\frac{8}{8}$} & $\begin{array}{l}\text { remoção de } \\
\text { vegetação }\end{array}$ & $\begin{array}{l}\text { remoção de vegetação existente no local de } \\
\text { implantaçăo do aterro. }\end{array}$ & $\begin{array}{l}\text { remoção de capoeira de porte } \\
\text { significativo }\end{array}$ & remoção da capoeira de menor porte & $\begin{array}{l}\text { remoção de reflorestamento } \\
\text { e/ou vegetaçấo herbácea. }\end{array}$ & área degradada. \\
\hline & $\begin{array}{l}\text { efeitos sobre a } \\
\text { fauna }\end{array}$ & $\begin{array}{l}\text { redução ou deslocamento da fauna eventualmente } \\
\text { existente no local de implantação do aterro. }\end{array}$ & $\begin{array}{l}\text { remoção de capoeira de porte } \\
\text { sem área de fuga }\end{array}$ & $\begin{array}{l}\text { remoção de vegetação herbácea elou } \\
\text { reflorestamento sem área de fuga. }\end{array}$ & $\begin{array}{l}\text { remoção de vegetação com } \\
\text { área de fuga. }\end{array}$ & área degradada. \\
\hline \multirow{6}{*}{ 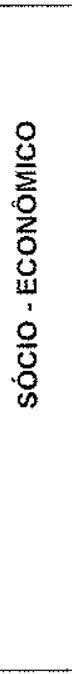 } & $\begin{array}{l}\text { desconforto } \\
\text { à } \\
\text { população }\end{array}$ & $\begin{array}{l}\text { desconforto causado à população da vizinhança } \\
\text { decorrente da repulsa natural ao empreendimento, } \\
\text { e da geração de gases, fumaça, odor e rúdos. }\end{array}$ & $\begin{array}{l}\text { existência de núcleos } \\
\text { habitacionais próximos e nắo } \\
\text { isolados da área. }\end{array}$ & $\begin{array}{l}\text { existência de núcleos urbanos } \\
\text { próximos, mas isolados da área. }\end{array}$ & $\begin{array}{l}\text { existência de ocupação } \\
\text { rarefeita nas proximidades } \\
\text { (sítios e chácaras) }\end{array}$ & $\begin{array}{l}\text { atividades do } \\
\text { entorno } \\
\text { compativeis com } \\
0 \text { empreendimento. }\end{array}$ \\
\hline & $\begin{array}{l}\text { desapropriaçōes } \\
\text { de bens } \\
e \text { atividades }\end{array}$ & $\begin{array}{l}\text { Incomodo aos proprietários causado pela } \\
\text { desapropriação das terras e benfeitorias nelas } \\
\text { existentes. }\end{array}$ & $\begin{array}{l}\text { presença de moradias } \\
\text { atividades produtivas }\end{array}$ & $\begin{array}{l}\text { presença de moradias ou atividades } \\
\text { econômicas. }\end{array}$ & presença de bens imóveis. & $\begin{array}{l}\text { área } \\
\text { desocupada. }\end{array}$ \\
\hline & $\begin{array}{l}\text { desvalorizaçāo } \\
\text { imobiliária }\end{array}$ & $\begin{array}{l}\text { desvalorização das propriedades da vizinhança } \\
\text { decorrente da implantação do aterro sanitário. }\end{array}$ & $\begin{array}{l}\text { área muito próxima da zona } \\
\text { urbana. }\end{array}$ & área cujo entorno mais próximo e rural. & - & $\begin{array}{l}\text { entorno já } \\
\text { degradado por } \\
\text { outras atividades }\end{array}$ \\
\hline & $\begin{array}{c}\text { tráfego de } \\
\text { veículos pesados }\end{array}$ & $\begin{array}{l}\text { Interferência do tráfego de veículos pesados } \\
\text { gerada pela atividade das vias de trânsito local. }\end{array}$ & \begin{tabular}{|l} 
circulação por vias locais \\
urbanas, com intensa \\
movimentaçāo de pedestres.
\end{tabular} & $\begin{array}{l}\text { circulação por vias locais urbanas, } \text { sem } \\
\text { riscos de pedestres. }\end{array}$ & $\begin{array}{l}\text { circulaçāo por viais locais com } \\
\text { tráfego atual similar ao gerado. }\end{array}$ & " \\
\hline & $\begin{array}{c}\text { riscos à } \\
\text { infra-estrutura } \\
\text { de serviços }\end{array}$ & $\begin{array}{l}\text { riscos de interrupção de funcionamento de serviços } \\
\text { públicos cuja infra-estruzura interfere com o local do } \\
\text { aterro. }\end{array}$ & $\begin{array}{l}\text { interferência cruzando a área, } \\
\text { com riscos à saúde pública }\end{array}$ & $\begin{array}{l}\text { interferências cruzando a área, com } \\
\text { riscos a atividade econômica. }\end{array}$ & $\begin{array}{l}\text { interferência tangenciando a } \\
\text { área }\end{array}$ & sem interferência. \\
\hline & $\begin{array}{l}\text { degradação } \\
\text { da paisagem }\end{array}$ & $\begin{array}{l}\text { degradação da paisagem decorrente da } \\
\text { implantação do aterro, associada a sua visibilldade } \\
\text { por eventuais observadores. }\end{array}$ & $\begin{array}{l}\text { local visivel de áreas } \\
\text { urbanizadas. }\end{array}$ & local visivel apenas de estradas. & local abrigado, não degradado. & $\begin{array}{l}\text { local abrigado } \\
\text { com entorno já } \\
\text { degradado. }\end{array}$ \\
\hline
\end{tabular}

Tabela 3.6 - . Parâmetros utilizados para a avaliação de impacto ambiental durante o processo de seleção de sítios no Município de São Paulo. Adaptado de Limpurb/Equipe Umah (1990). 


\subsubsection{Principais caracteristicas das áreas analisadas}

As principais características dos sete sítios analisados encontram-se descritas na tabela 3.7 .

O sítio da Pedreira Aidar está inserido sobre uma cava de extração de gnaisse para brita. De acordo com a compartimentação acima, estes terrenos apresentam potencial pouco favorável para uso como aterro.

Em relação aos aspectos geomorfológicos, praticamente todos os sitios estavam inseridos em anfiteatros com vertentes suavizadas e vales encaixados, com áreas alagadiças de várzeas associadas. Com exceção do sítio Pedrinhas que situava-se sobre a planície do Rio Pedrinha, em antigas cavas de mineração de argila.

Nesta caracterização não foram considerados os condicionantes geológicos de cada área, tais como, litologia e presença de estruturas rúpteis dos maciços. Também não foram consideradas as características texturais e hidráulicas do substrato, visando avaliar a sua permeabilidade. A caracterização hidrológica ficou restrita aos recursos hidricos superficiais, não sendo realizada nenhuma análise do regime das águas subterrâneas.

De acordo com Rodriguez (1998), todos os sítios, com exceção do Sítio Pedreira Aidar, encontram-se sobre rochas xistosas, compostas por biotita-muscovita-xistos e granada-biotitaxistos parcilmante migmatizados. De acordo com a compartimentação física para a disposição de resíduos realizada pelo Consórcio Hicsan/Etep (1994), estas áreas apresentam potencial favorável para uso como aterros sanitários (tabela 2.11 - pag. 30).

Para os meios biótico e sócio-econômico foram caracterizados o uso e a ocupação do solo, ocupação do entorno e as principais condições de acesso, conforme é apresentado sucintamente na tabela 3.7 .

\subsubsection{Seleção final do sítio}

A primeira etapa do processo de seleção do sítio foi realizada através da integração das caracteristicas ambientais de cada sítio com os impactos esperados, caso fosse implantado e operado o aterro sanitário.

No Grupo da $3^{a}$ Divisão foram descartados os sítios Minami e o Sítio Ribeirão Verde devido a ocupação urbana do entorno. No caso do Sítio Ribeirão Verde, o impacto sobre a reação da vizinhança foi considerado de menor intensidade. O grande fator de exclusão foi a presença do Aqueduto Rio Claro que inviabilizava a implantação do aterro, pela impossibilidade de sua remoção.

No Grupo Santa Etelvina, os dois sitios foram descartados. O Sítio Pedrinhas foi descartado principalmente devido as suas condiçōes hidrológicas e geomorfológicas. Estava inserido sobre a várzea do Rio Pedrinha, em antigas cavas de extração de argila, onde o freático era aflorante. Além disto apresentava densa ocupação no entorno e péssimas condiçôes de 


\begin{tabular}{|c|c|c|c|c|c|c|c|}
\hline \multicolumn{2}{|c|}{ Sitios } & \multicolumn{2}{|r|}{ MElo Fisico } & \multicolumn{3}{|c|}{ MEIO BIÓTICO/SÓCIO-ECONÔMICO } & \multirow{2}{*}{ GERAL } \\
\hline GP & ÁREA & $\begin{array}{l}\text { SITUAÇĀO } \\
\text { GEOMORFOLOOGICA }\end{array}$ & $\begin{array}{l}\text { ASPECTOS } \\
\text { HIDROLÓGICOS }\end{array}$ & $\begin{array}{l}\text { USO E OCUPAÇÃO } \\
\text { DO SOLO }\end{array}$ & VIZINHANÇA & $\begin{array}{l}\text { CONDIÇÖES DE } \\
\text { ACESSO }\end{array}$ & \\
\hline \multirow{4}{*}{ 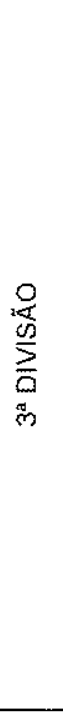 } & $\begin{array}{l}\text { Sítio } \\
\text { Minami }\end{array}$ & \begin{tabular}{|l} 
- relevo suave, com duas \\
vertentes, separadas pelo \\
espigão que divide as sub. \\
bacias dos ribeiróes dos \\
Cochos \& Gabirobeira. \\
\end{tabular} & - fundo de vale com cursos de água perenes; & $\begin{array}{l}\text { - predomina capoeira de } \\
\text { porte significativo; } \\
\text { - vegetaçâo herbácea; } \\
\text { - reflorestamento; } \\
\text { - hortifruticultura. } \\
\end{array}$ & áreas urbanizadas. & & $\begin{array}{l}\text { - desprovida de } \\
\text { barreira natural. }\end{array}$ \\
\hline & $\begin{array}{l}\text { Sítio } \\
\text { Floresta }\end{array}$ & $\begin{array}{l}\text { - vale encaixado, com } \\
\text { encostas suavizadas. }\end{array}$ & - nascente do rib. dos Cochos represada; & $\begin{array}{l}\text { - pastagens; } \\
\text { - reflorestamento; } \\
\text { - edificaçōes rurais; } \\
\text { - gasoduto. }\end{array}$ & $\begin{array}{l}\text { - cobertura vegetal variada, } \\
\text { - pequenas áreas } \\
\text { urbanizadas em Mauá. }\end{array}$ & pavimentado & - há barreira natural. \\
\hline & $\begin{array}{l}\text { Sítio } \\
\text { Sāo João }\end{array}$ & $\begin{array}{l}\text { - amplo anfiteatro circundado } \\
\text { por terrenos de topografia } \\
\text { plana; } \\
\text { - área de várzea próxima. }\end{array}$ & $\begin{array}{l}\text { - regiāo de cabeceira de drenagem, com } \\
\text { fundos de vales formando pequenos cursos de } \\
\text { água; } \\
\text { - área de várzea com freático raso adjacente. }\end{array}$ & $\begin{array}{l}\text { - capoeira de porte; } \\
\text { - reflorestamento; } \\
\text { - vegetaçāo herbácea; } \\
\text { - mata; } \\
\text { - gasoduto. }\end{array}$ & $\begin{array}{l}\text { - idem } \\
\text { - limite com área de } \\
\text { Proteção aos Mananciais. }\end{array}$ & pavimentado & $\begin{array}{l}\text { - desprovida barreira } \\
\text { natural. }\end{array}$ \\
\hline & $\begin{array}{l}\text { Sítio } \\
\text { Ribeirão } \\
\text { Verde }\end{array}$ & $\begin{array}{l}\text { - amplo fundo de vale na } \\
\text { forma de anfiteatro, com } \\
\text { amplitudes topográficas } \\
\text { elevadas; } \\
\text { áreas rebaixadas } \\
\text { compostas por várzeas. }\end{array}$ & $\begin{array}{l}\text { - região de cabeceira, com fundos de vales } \\
\text { menores que formam o ribeirão dos Cochos; } \\
\text { - áreas de várzea, com freático raso. }\end{array}$ & $\begin{array}{l}\text { - capoeiras de porte; } \\
\text { - reflorestamento; } \\
\text { - vegetaçăo herbácea; } \\
\text { - algumas residencias; } \\
\text { - cortado diametralmente } \\
\text { por aqueduto da } \\
\text { SABESP. }\end{array}$ & $\begin{array}{l}\text { - cobertura vegetal; } \\
\text { - Sítio São João; } \\
\text { - pequeno núcleo urbano. }\end{array}$ & - nāo pavimentado & - há barreira natural. \\
\hline \multirow{2}{*}{ 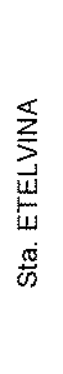 } & $\begin{array}{l}\text { Sitio } \\
\text { Pedrinhas }\end{array}$ & - topografia suavizada. & $\begin{array}{l}\text { - lagoas formadas à partir do afloramento do } \\
\text { freático nas cavas de extração de argila, na } \\
\text { várzea do Rio Pedrinha; } \\
\text { - fundos de vale, pequenos cursos de água } \\
\text { perenes. }\end{array}$ & $\begin{array}{l}\text { - extração de argila; } \\
\text { - vegetação herbácea; } \\
\text { - reflorestamento nas } \\
\text { porçōes mais altas }\end{array}$ & $\begin{array}{l}\text { - cobertura vegetal variada; } \\
\text { - núcleos urbanos. }\end{array}$ & $\begin{array}{ll}\text { - acessos } & \text { locais } \\
\text { estreitos a } & \text { não } \\
\text { pavimentados. } & \end{array}$ & \\
\hline & $\begin{array}{c}\text { Sítio } \\
\text { Conceiçăa }\end{array}$ & - amplo vale encaixado. & $\begin{array}{l}\text { - no vale, pequeno curso de água perene, } \\
\text { contribuinte do Rio ltaquera. }\end{array}$ & $\begin{array}{l}\text { - predomina capoeira de } \\
\text { porte com importância } \\
\text { regional; } \\
\text { - reflorestamento; } \\
\text { - vegetação herbácea. }\end{array}$ & $\begin{array}{l}\text { - cobertura vegetal variada; } \\
\text { - chácaras, } \\
\text { - Sítio Pedrinhas; } \\
\text { - coniuntos habitacionais. }\end{array}$ & $\begin{array}{l}\text { - acesso é dado por } \\
\text { arruamento } \quad \text { com } \\
\text { tráfego intenso de } \\
\text { pedestres. }\end{array}$ & $\begin{array}{l}\text { - desprovida barreira } \\
\text { natural. }\end{array}$ \\
\hline 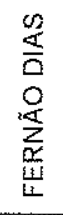 & $\begin{array}{l}\text { Sítio } \\
\text { Pedreira } \\
\text { Aidar }\end{array}$ & $\begin{array}{l}\text { - vale encaixado nã porção } \\
\text { baixa; } \\
\text { - anfiteatro, na porção alta. }\end{array}$ & $\begin{array}{l}\text { - curso de água intermitente, contribuinte do } \\
\text { córrego Piracema, aftuente do Engordador. }\end{array}$ & $\begin{array}{l}\text { - pedreira desativada; } \\
\text { - vegetaçäo herbácea; } \\
\text { - capoeira; } \\
\text { pátio de equipamentos; } \\
\text { - depósito de materiais; } \\
\text { - algumas residências. }\end{array}$ & $\begin{array}{l}\text { - vegetação variada; } \\
\text { - pedreira em operaçāo; } \\
\text { - lixāo de Guarulinos; } \\
\text { - indústrias; } \\
\text { - extraçâo de areia; } \\
\text { - escola. }\end{array}$ & $\begin{array}{l}\text { - estradar râo } \\
\text { pavimentada, com } \\
\text { tráfego de caminhōes } \\
\text { pesados. }\end{array}$ & $\begin{array}{l}\text { - baixa capacidade } \\
\text { de volume. }\end{array}$ \\
\hline
\end{tabular}

Tabela 3.7 - Principais características dos sítios analisados no Município de São Paulo, SP (Adaptado de Limpurb/Equipe Umah, 1990). 
acesso. O Sítio Conceição foi descartado pela presença de conjuntos habitacionais no entorno e pelo intenso tráfego de pedestres na principal via de acesso à área.

As áreas pré-selecionadas compreenderam os sítios Floresta e São João (Grupo $3^{a}$ Divisão) e o Sítio Pedreira Aidar (Grupo Fernão Dias).

Dentre os três sítios, o Sítio Pedreira Aidar foi considerado como a melhor alternativa para a implantação do aterro. As razões atribuidas a sua potencialidade foram a baixo indice de rejeição da população, e a possibilidade de recuperação da área degradada. Apresentava como fator desfavorável a baixa capacidade de volume e a distância.

Os sitios Floresła e São João foram considerados favoráveis pelas suas características físicas e sócio-econômicas. A maior restrição foi atribuída à presença de capoeira no Sítio São João e da necessidade de seu desmatamento.

Os fatores que realmente decidiram pela escolha do sítio foram a vida útil (custo/benefício), condições de acesso e ocorrência de áreas de empréstimo para a cobertura dos resíduos.

De acordo com a análise realizada, concluiu-se que em relação a vida útil - somente o aterro São João atendeu a estimativa de uma vida útil superior a 5 anos.

Em relação as condições de acesso, as três áreas apresentavam as mesmas caracteristicas. A Pedreira Aidar, em relação as demais, apresentou distância bem maior do centro gerador de resíduos.

As áreas de empréstimos existentes no próprio perímetro dos dois sítios da $3^{a}$ Divisão eram suficientes para atender toda a vida útil de operação do aterro, ao contrário da Pedreira Aidar, que apresentou escassez de material de empréstimo.

De acordo com os critérios adotados e apresentados acima, o Sítio São João foi considerado ambientalmente o mais adequado para a implantação do aterro sanitário

\subsubsection{Caracterização geral do Aterro Sanitário São João}

O Aterro Sanitário São João está inserido na porção Leste do Município de São Paulo, na Área da Administração Regional de São Mateus. O centro geométrico do aterro está nas coordenadas geográficas UTM (0355080 - 738491)

A área total do aterro é de 50 hectares, e a porção recoberta por resíduos é de aproximadamente 47 hectares (1998). É limitada a Sudeste pelo divisor de águas dos ribeirões dos Cochos e do Coaguaçu, marco da divisa dos municípios de São Paulo e Mauá (ABCD). O limite Oeste é dado pela planície do Córrego Floresta, a qual se estende a Estrada de Sapopemba (figura 3.14 - pag. 104 e figura 3.15 - pag. 109 ). 
As principais alternativas de acesso são as avenidas Aricanduva e Raqued Chohfi, e as estradas da $3^{a}$ Divisão e de Sapopemba, onde a portaria do aterro fica na altura do kilômetro 33. (figura 3.15).

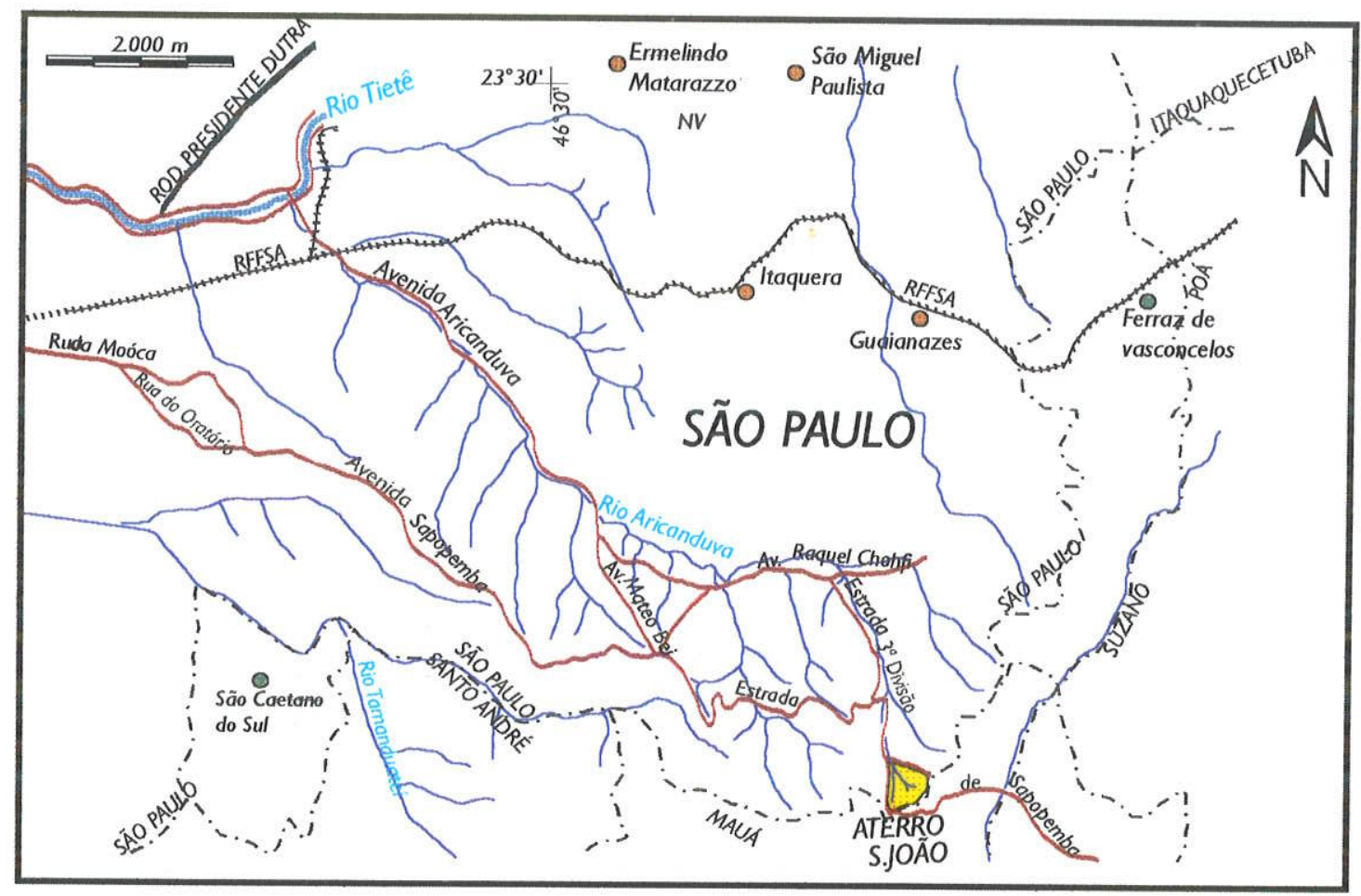

Figura 3.15 - Localização e principais vias de acesso do aterro sanitário São João/SP.

O aterro entrou em operação em 24 de dezembro de 1992. Desde então, recebeu mais de 10.000 milhões de toneladas de resíduos urbanos, em 8 anos de sua existência (foto 32).

O início da sua operação foi sobre as cabeceiras de drenagem do córrego Floresta, contribuinte da margem direita do Rio Aricanduva.

Atualmente recebe os resíduos provenientes da zona leste e sul de São Paulo, totalizando cerca de 6.000 toneladas diárias.

As células de resíduos apresentam 4 metros de altura, que são isoladas através de camadas de argila com espessura média de 20 centímetros, e para cada célula, há canalizações para a coleta de chorume.

As porções topograficamente mais rebaixadas foram aterradas por uma camada de aproximadamente 1 metro de argila compactada. Sobre esta camada foi aplicada uma manta de polietileno de alta densidade, com $3 \mathrm{~mm}$ de espessura, na forma de faixas soldadas "in situ", recobrindo-a com um aterro compactado de 1,00 metro de espessura. 
A impermeabilização através de manta sintética é ao longo de todo o aterro, inclusive nas vertentes do anfiteatro (fotos 32,33 e 36).

Nas diversas nascentes de água existentes foram implantadas obras de canalizações. Estas águas são coletadas em uma caixa de concreto, pouco a jusante do aterro (foto 37). Nesta mesma caixa, são coletadas as águas de um dos formadores do córrego Floresta, que nasce fora da área do aterro e é canalizado sob a área do aterro. As águas residuárias das instalações administrativas do aterro são também enviadas para esta caixa, e posteriormente, encaminhadas para o leito do córrego.

O chorume é coletado ao longo de todas as células de resíduos (fotos 37 e 38), e armazenado temporariamente em duas lagoas implantadas à jusante do aterro (foto 34). $O$ chorume coletado é transferido para a Estação de Tratamento de Esgotos da SABESP. A vazão de chorume varia sensivelmente durante o ano. Durante o período de outubro/1996 a outubro/1997, a descarga variou entre 9,2 e 13,5 litros/segundo.

As águas subterrâneas e a composição do chorume são monitoradas periodicamente.

\subsubsection{Geologia}

O substrato rochoso da área é composto essencialmente por micaxisto com intercalações decimétricas a métricas de quartzito, pertencentes ao Complexo Embú (CPRM, 1990). Os afloramentos de rocha são escassos, recobertos por uma espessa cobertura de solos residuais. Nos taludes de corte, afloram rochas xistosas alteradas (foto 35).

As estruturas principais dos micaxistos e quartzitos são a foliação metamórfica e as fraturas. As falhas existentes são pouco representativas e de pequena extensão.

A foliação é representada por uma xistosidade marcante nos micaxistos, com atitude muito constante, com direção predominante de N3OE e mergulho de 40 NW. Nas proximidades do vale, o mergulho torna-se subhorizontal para SE evidenciando um dobramento sinformal da xistosidade na área do aterro.

O conjunto de fraturas mais freqüente apresenta atitude média N45-65W/75NE, com densidade de ocorrência bastante variável. Foi observada uma densidade de 5 a 10 fraturas por metro linear e a presença de óxido de ferro e mangânes ao longo dessas fraturas. Os demais conjuntos de fraturas apresentam atitudes em torno de N30E/50SE e N2OE/55NW.

Nos fundos de vales, ocorrem aluviões que são constituídos essencialmente por areias e argilas inconsolidadas. 


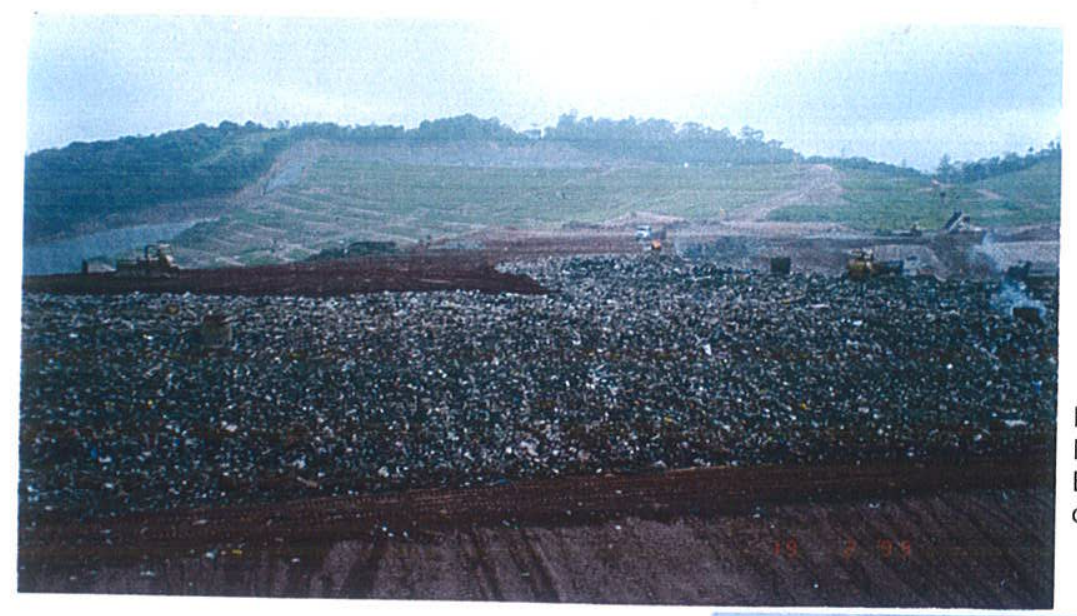

Foto 32 - Aterro sanitário São João.

No fundo, antiga área de disposição.

Em primeiro plano, frente de

disposiçäo em 1999.

Foto 33 - Vista lateral do aterro. Nota-se o anfiteatro preenchido através de células de resíduos. Na vertente esquerda, nota-se a impermeabilização com manta.
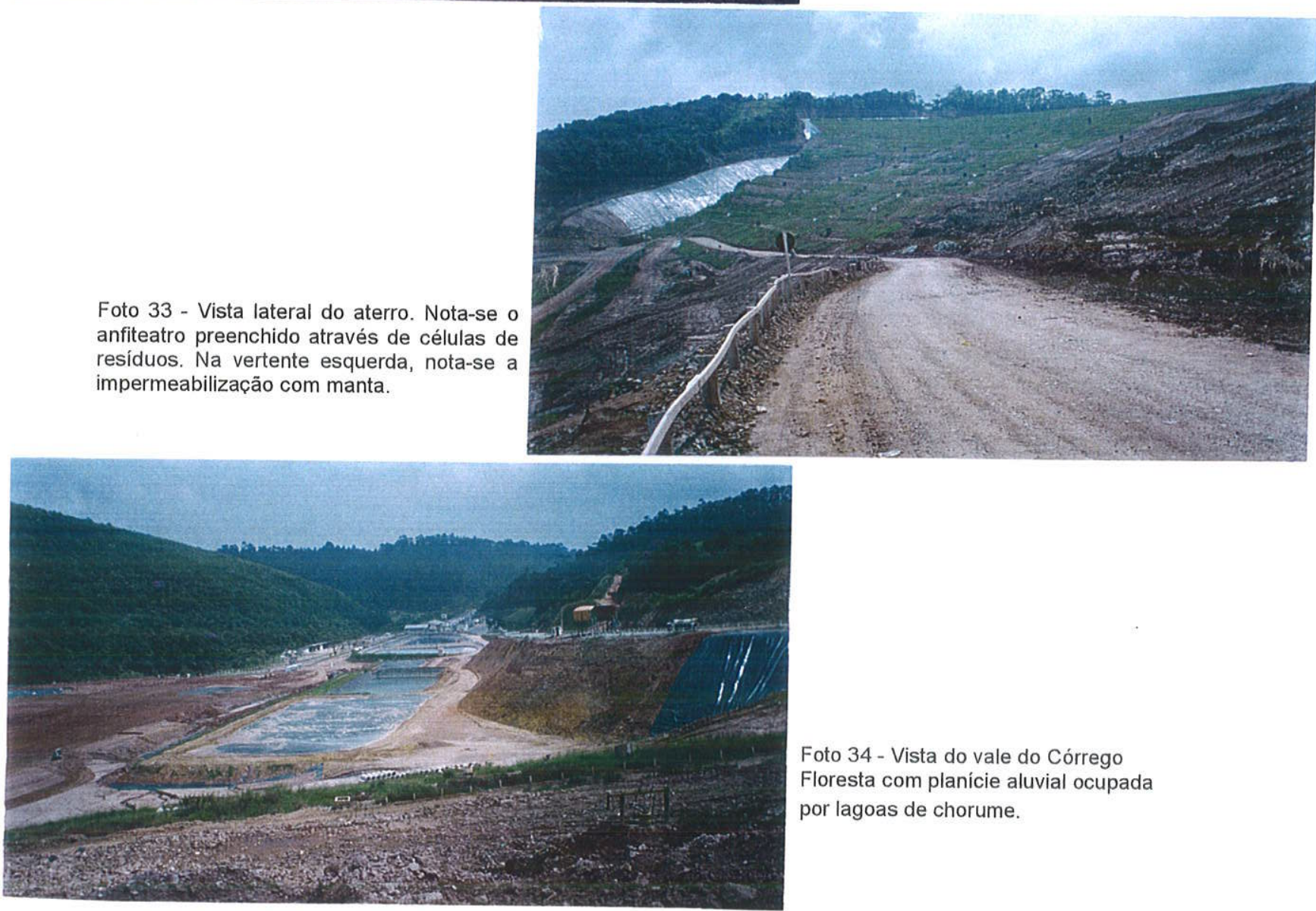

Foto 34 - Vista do vale do Córrego

Floresta com planície aluvial ocupada

por lagoas de chorume.

Foto 35 - Corte na vertente do anfiteatro exibindo micaxistos alterado com lentes de quartzito.

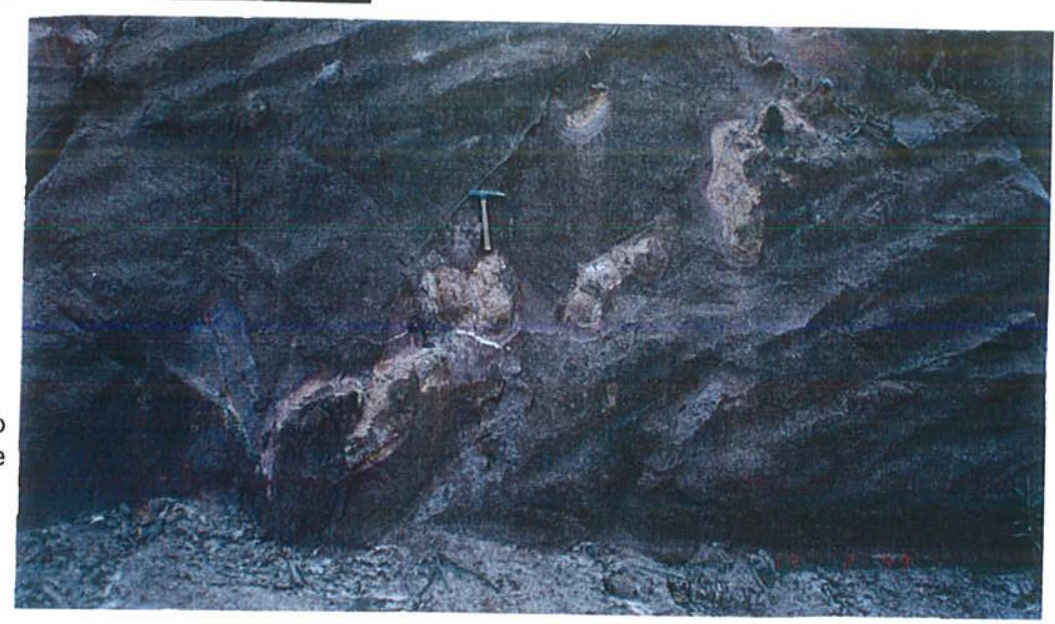




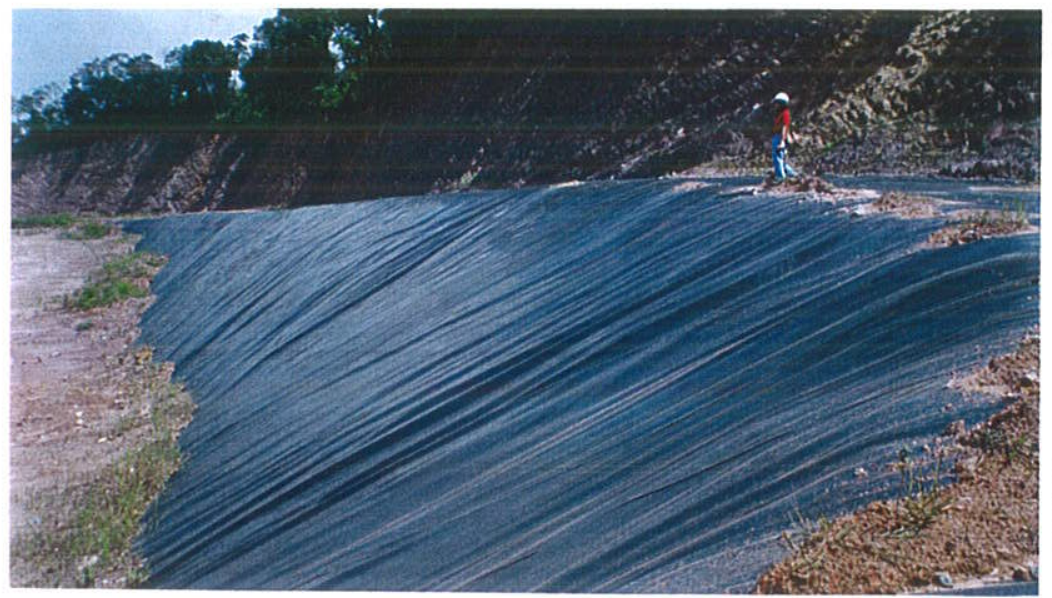

Foto 36 - Vertente esquerda do aterro com corte de talude em micaxisto e manta de impermeabilização.

Foto 37 - Poço de coleta de chorume. Ao fundo, células de disposição com canalização de nascentes e escada para escoamento das águas pluviais.
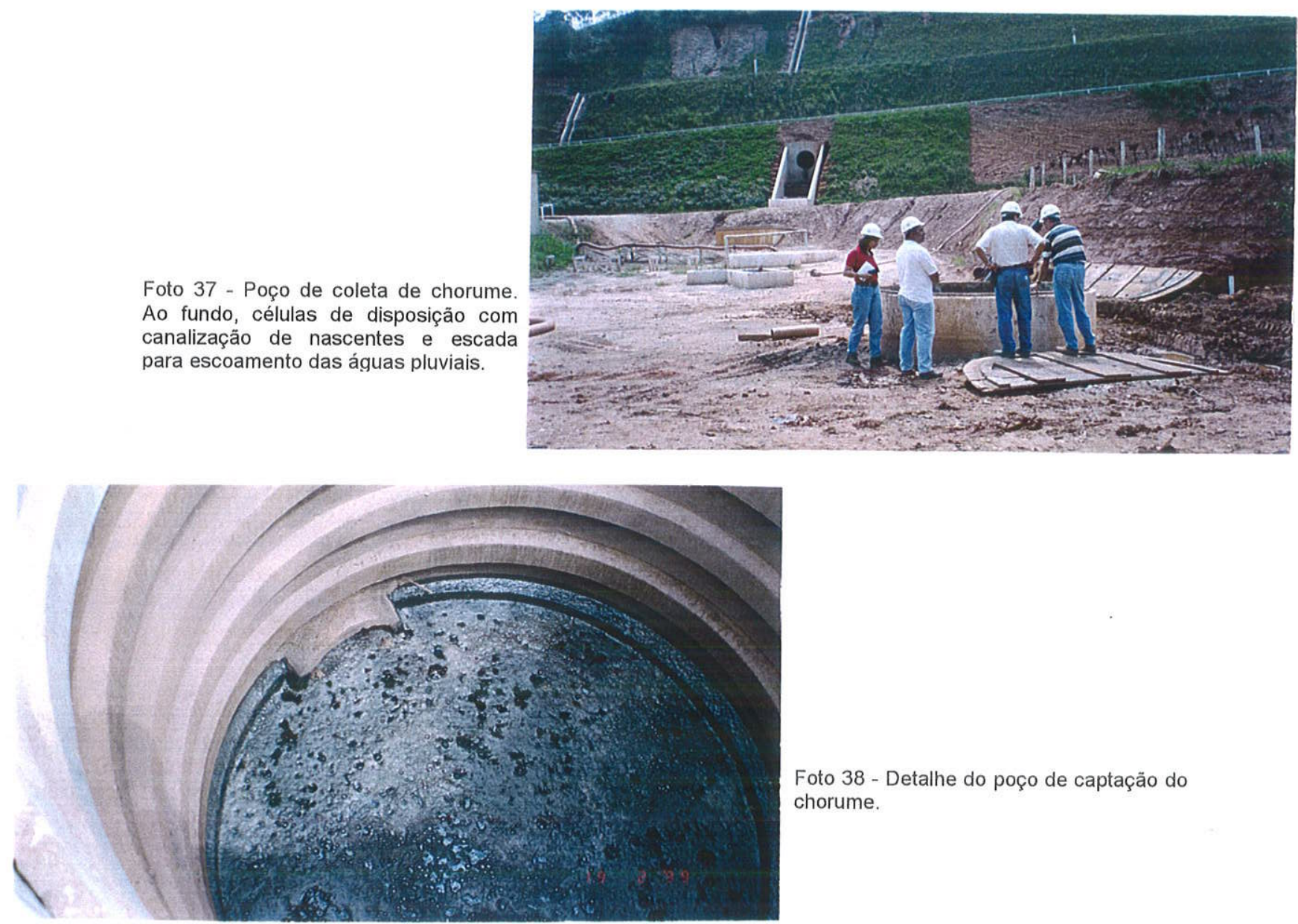

Foto 38 - Detalhe do poço de captaçäo do chorume.

Foto 39 - Poço de monitoramento de águas subterrâneas situado montante do aterro, no limite Leste.

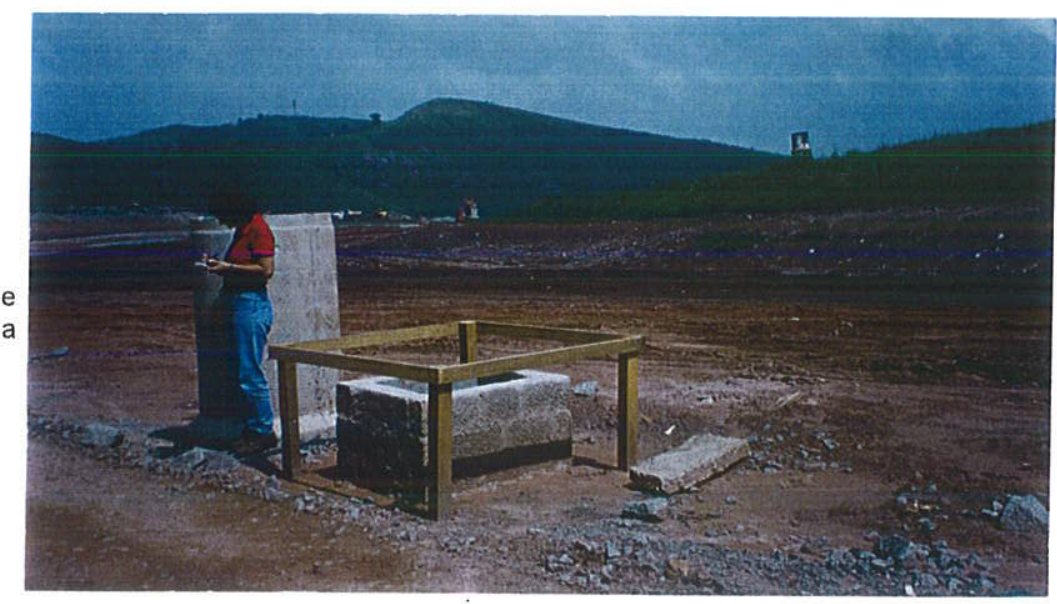




\subsubsection{Geomorfologia}

A região do aterro perience a província geomorfológica do Planalto Atlântico, localmente denominada de Zona do Planalto Paulistano (Almeida, 1964).

O aterro foi implantado sobre cabeceiras de drenagem (anfiteatro) de direção geral de WNW - ESE, com vertentes assimétricas. As encostas voltadas para o Norte são predominantemente côncavo - convexas, e as voltadas para o Sul são retilíneas. A área caracteriza-se pela presença de morros arredondados com espesso manto intempérico.

A porção mais rebaixada do sitio é representada por um fundo de vale aberto e fundo plano.

\subsubsection{Cobertura superficial e aspectos geotécnicos}

A cobertura superficial na área do aterro é constituída por solos superficiais, coluviões, aluviões, depósitos de tálus e solo de alteração de rocha.

Os solos de alteração são provenientes do intemperismo de micaxistos intercalados com camadas pouco espessas de quartzitos. São constituidos por silte arenoso, pouco argiloso, micáceo, coloração rosada a castanha avermelhada. A concentração de areia aumenta na ocorrência de camadas de quartzito.

De acordo com as sondagens a percussão realizadas no sítio, na ocasião de seu licenciamento ambiental (EIA/RIMA) e o projeto básico, estima-se que nas porções mais altas do aterro (nos anfiteatros) a espessura da cobertura de solo varia entre 15 e 20 metros. Nas partes mais baixas, ao longo da planicie, deve estar entre 20 e 30 metros (Equipe Umah, 1990).

A resistência a penetração varia de 7 golpes por $30 \mathrm{~cm}$, nos trechos próximos à superfície, aumentando em profundidade, para até 27 golpes por $30 \mathrm{~cm}$. (Epal, 1994).

Os argilo-minerais presentes nos solos residuais, conforme as análises mineralógicas, são representados principalmente pelo grupo das caolinitas e, subordinadamente, pelos grupos da illita, das argilas de camadas mistas illita-vermiculita e das vermiculitas. A capacidade de troca cationnica (CTC) é baixa, variando de 2,1 a 4,2 $\mathrm{mEq} / 100 \mathrm{~cm}^{3}$, que são valores típicos para este tipo de solo. A granulometria, a mineralogia das argilas e a CTC indicam uma baixa capacidade de auto depuração para o chorume proveniente da massa de resíduos.

\subsubsection{Hidrogeologia}

Conforme descrito no item geologia, o substrato do aterro é constituído predominantemente por rochas xistosas recobertas por um espesso manto de alteração e depósitos aluvionares ao longo da calha do córrego. 
De acordo com dados do DAEE (1975) a recarga medida próxima a área de aterro (subbacia Aços Anhanguera) é de $1,477 \times 10^{-8} \mathrm{~m} / \mathrm{s}$. A transmissividade do embasamento varia entre $1,62 \times 10^{-4} \mathrm{e} 4,63 \times 10^{-6} \mathrm{~m}^{2} / \mathrm{s}$.

De modo geral, na área do aterro estão presentes três tipos de aqüiferos: o aluvionar, que hoje encontra-se completamente descaracterizado devido as obras de corte e aterros para a implantação das lagoas de armazenamento de chorume; o aqüifero poroso associado ao manto de alteração (material sítico-arenoso) e o embasamento cristalino com aqüifero fraturado, representado pela xistosidade fraturas e falhas do embasamento cristalino.

Como o substrato rochoso é praticamente impermeável, as descontinuidades estruturais são responsáveis pelo fluxo de água subterrânea nos micaxistos. Entre estas estruturas, ressaltamse, do ponto de vista da permeabilidade as fraturas NW-SE, algumas falhas e camadas de quartzito.

Os ensaios de infiltração executados nas sondagens realizadas na ocasião do Projeto Executivo indicaram que a permeabilidade é extremamente variável, entre $10^{-3} \mathrm{~cm} / \mathrm{s}$ até praticamente impermeáveis, com valor médio de $10^{-4} \mathrm{~cm} / \mathrm{s}$ para o manto de intemperismo. Nas partes mais profundas do solo de alteração testes de permeabilidade indicaram valores entre $10^{-4}$ a $10^{-6} \mathrm{~cm} / \mathrm{s}$.

No solo de alteração os fluxos subterrâneos apresentam-se controlados pela topografia. Desta forma, o fluxo é convergente em direção à jusante do aterro, alinhando-se em direção ao córrego Floresta.

Com a finalidade de obter-se informações à respeito da profundidade do N.A. e da qualidade da água subterrânea, na ocasião da elaboração do Estudo impacto Ambiental (EIA/RINA) foram realizadas algumas investigações geofísicas, que compreenderam ensaios de eletrorresistividade (sondagem elétrica vertical) e eletromagnético indutivo. Foram instalados poços de monitoramento das águas subterrâneas (hoje desativados) e realizadas amostragens para análises físico-químicas.

Para a investigação geofísica, foram executadas quatro sondagens elétricas, na porção mais rebaixada do relevo. O arranjo de eletrodos utilizado foi de Schlumberger, com eletrodos de corrente distanciados até 200 metros, o suficiente para investigar profundidades em torno de 70 metros. De acordo com os resultados obtidos, a profundidade do topo rochoso varia entre 40 e 50 metros na porção mais rebaixada do relevo. As profundidades do nivel d'água não foram determinadas com precisão (Equipe Umah, 1990).

Foi realizado também o caminhamento eletromagnético onde pretendia-se determinar eventuais plumas de contaminação existentes no local, antes da implantação e operação do empreendimento.

Os perfis foram realizados utilizando 3 arranjos de bobina EM-31-V, EM-34/20m-H e EM$34 / 20 \mathrm{~m}-\mathrm{V}$, para investigar respectivamente 6,15 e 30 metros de profundidade. Os perfis de 
condutividade obtidos mostraram que, não haviam áreas anômalas que poderiam corresponder a manchas de poluição.

Foi escavado um poço de monitoramento, para coleta e análise da água subterrânea na porção topograficamente mais rebaixada do sítio. As escavações mostraram que a profundidade do nivel d'água, varia entre 0,90 a 5,40 metros.

Na profundidade 5,40 metros, a amostra coletada e analisada indicou que a concentração dos elementos analisados encontravam-se todos dentro do limite máximo estabelecido pelos padrões nacionais e internacionais de potabilidade de água Os valores obtidos encontram-se relacionados abaixo.

\begin{tabular}{|c|c|c|c|c|c|c|c|c|c|c|c|c|}
\hline $\begin{array}{l}T_{\text {agua }} \\
\left({ }^{\circ} \mathrm{C}\right)\end{array}$ & $\mathrm{pH}$ & $\begin{array}{c}\text { Cond. } \\
\text { elétrica } \\
\text { (uSi/cm) }\end{array}$ & $\begin{array}{c}\mathrm{CO}_{2} \\
\text { livre } \\
\text { (mg/L) }\end{array}$ & $\begin{array}{c}\text { Alcalinidade } \\
\mathrm{HCO}_{3}^{-} \\
(\mathrm{mg} / \mathrm{L})\end{array}$ & $\begin{array}{c}\text { Alcalinidade } \\
\mathrm{CaCO}_{3}^{-} \\
(\mathrm{mg} / \mathrm{L})\end{array}$ & $\begin{array}{c}\mathrm{Cl}^{-} \\
(\mathrm{mg} / \mathrm{L})\end{array}$ & $\begin{array}{c}\mathrm{NO}_{3} \\
(\mathrm{mg} / \mathrm{L})\end{array}$ & $\begin{array}{c}\mathrm{SO}_{4}{ }^{2-} \\
(\mathrm{mg} / \mathrm{L})\end{array}$ & $\begin{array}{l}\mathrm{HPO}_{4}{ }^{2} \\
(\mathrm{mg} / \mathrm{L})\end{array}$ & $\begin{array}{c}F \\
(m g / L)\end{array}$ & $\begin{array}{c}\mathrm{Br}^{\circ} \\
(\mathrm{mg} / \mathrm{L})\end{array}$ & $\begin{array}{c}\mathrm{NO}_{2}{ }^{-} \\
(\mathrm{mg} / \mathrm{L})\end{array}$ \\
\hline 20 & 5,40 & 123 & 72,6 & 3,6 & 0 & 7,27 & 4,50 & 4,00 & nd & nd & nd & nd \\
\hline
\end{tabular}

Tabela 3.8 Principais características físico-químicas das águas subterrâneas na área do aterro. Adaptado de Equipe Umah (1990)

De acordo com os resultados obtidos e a profundidade do ponto de amostragem pode se concluir que a concentração acima indica se tratar de uma água originária do manto de intemperismo, onde o baixo valor de condutividade elétrica indica a baixa concentração de ions dissolvidos, refletindo percolação em solo lixiviado com pouca presença de rocha.

Os valores encontrados acima, apesar de corresponderem somente a uma análise pontual, serão utilizados para subsidiarem na análise das águas subterrâneas com a implantação e operação do aterro sanitário. Sabe-se que estes valores são correspondentes a composição da água sem a intervenção do empreendimento, podendo ser utilizado portanto, com ressalvas, como parâmetro de comparação de concentração, isto é, o background da região.

\subsubsection{5 Águas Supenficiais}

O aterro sanitário São João está inserido sobre a cabeceira de drenagem de um tributário da margem esquerda, contribuinte da formação do Rio Aricanduva, afluente da margem esquerda do Rio Tietê, conforme mostra a figura a seguir.

A bacia do Rio Aricanduva drena grande parte da zona leste do municipio, e onde concentra-se parcela considerável de ocupação habitacional. A qualidade dessas águas encontrase seriamente comprometida principalmente à partir do córrego Coaguaçu devido ao lançamentos de esgotos em geral.

Os cursos de água desta bacia são classificados como da Classe IV, de acordo com os Decretos Estaduais $N^{\circ} 8.468 / 76$ e 10.755/77. 


\subsubsection{Pluviosidade}

$\mathrm{Na}$ área do aterro há um posto de medição da pluviosidade, operado pela Enterpa Ambiental S.A. Os dados parciais do período de outubro/1996 a outubro/1997 encontram-se listados na tabela apresentada no subitem caracterização geral do aterro.

Conforme mostram as tabelas e gráficos a seguir, o período mais chuvoso corresponde aos meses de dezembro e janeiro, com média total superior a $267 \mathrm{~mm}$. Os periodos menos chuvosos foram abril, maio, julho e agosto, com índice inferior a $73 \mathrm{~mm}$.

\subsubsection{Monitoramento ambiental}

O principal objetivo de analisar as condições ambientais das águas superficiais e subterrâneas de um aterro sanitário em operação foi avaliar a eficácia dos procedimentos de escolna de sítios para aterros sanitários e sua posterior operação.

Conforme já ciłado, o aterro sanitário São João foi escolhido devido as suas particularidades ambientais, pois a maioria dos aterros sanitários já foram operados no passado na forma de lixão. Podemos citar alguns exemplos, como o Aterro Sanitário de Santo André (em operação desde o inicio da década de 80), o Aterro Sanitário Lara (Mauá/SP - em operação desde 1987), Aterro Sanitário Bandeirantes (São Paulo/SP - em operação desde 1979), e o Aterro Sanitário de Osasco (Osasco/SP).

A implantação do aterro $S$. João envolveu o processo de seleção de áreas e a realização dos projetos básico e executivo. As águas subterrâneas e o chorume são monitorados periodicamente, com coleta $e$ análise das amostras. Ao contrário das águas superficiais, que são muito pouco monitoradas.

Conforme descrito no item caracterização do empreendimento, o projeto do aterro foi concebido de forma a permitir o total isolamento do chorume, sem nenhum contato com o solo subjacente ao aterro, e consequentemente com o freático.

O substrato do aterro, nos anfiteatros, é composto principalmente por solos de alteração de micamxistos, com conteúdo de finos que varia de 32 a $46 \%$ e baixas permeabilidades, em geral, entre $10^{-6}$ e $10^{-8} \mathrm{~m} / \mathrm{s}$. De acordo com as análises realizadas no solo, a sua capacidade de auto depuração dos contaminantes do aterro é baixa (Epal,1994).

Hoje, decorrente das sucessivas ampliações que ocorreram desde a sua implantação, a superfície recoberta por resíduos já avançou para as duas vertentes do Córrego Floresta, muito maior em relação ao projeto inicial.

A tabela 2.4 - pag. 13, apresenta a composição físico-químca e bacteriológica média do chorume gerado pelo aterro São João durante o período de 1997 a 2000. Nota-se a coloração acentuada do líquido (9.740 mg Pt/L), a elevada DBO - demanda Bioquímica de Oxigênio 
(8.375mg/L - maior em média a 35 vezes de esgotos sanitários), em acordo com a definição de chorume da NBR 8419/1992.

Nota-se as altas concentrações de cálcio $(1.150 \mathrm{mg} / \mathrm{L})$, cloreto $(2.110 \mathrm{mg} / \mathrm{L})$, magnésio (340 mg/L) e sódio (2.108 mg/L).

A presença de metais pesados, destacando-se o cádmio $(0,03 \mathrm{mg} / \mathrm{L})$, chumbo $(0,20 \mathrm{mg} / \mathrm{L})$, estanho $(2,27 \mathrm{mg} / \mathrm{L})$, o níquel $(0,41 \mathrm{mg} / \mathrm{L})$, o cobre $(0,05 \mathrm{mg} / \mathrm{L})$, manganês $(0,77 \mathrm{mg} / \mathrm{L})$, e o zinco $(1,06 \mathrm{mg} / \mathrm{L})$.

A altíssima Demanda Química de Oxigênio - DQO de $13.141 \mathrm{mg} / \mathrm{L}$, que indica o alto poder poluidor do chorume, pois concentrações acima de $10 \mathrm{mg} / \mathrm{L}$ nas águas subterrânea já são indicativas de poluição.

A elevada concentração de componentes microbiológicos, representados principalmente pelos coliformes fecais/ totais e bactérias.

A coleta e a análise das amostras de chorume, águas superficiais e subterrâneas mais recentes foram realizadas pela Ambiental Laboratórios e Equipamentos Ltda, e as demais (1992 e 1993) pela Puríquima Ltda. As coletas foram realizadas em consonância com o Guia de Coleta e Preservação de Amostras - CETESB e Normatização Técnica CETESB 06.010 - ABR/88 Construção de Poços de Monitoramento de Aqüífero Freático.

\subsubsection{Análise das águas superficiais}

Atualmente o aterro sanitário São João está inserido sobre as duas vertentes que abrigam as nascentes do Córrego Floresta, afluente da margem esquerda do Rio Aricanduva. Trata-se de um córrego de vazão pequena com leito sobre sedimentos aluvionares a jusante, e nas cabeceiras sobre manto intempérico de micaxistos.

As águas de nascentes são coletadas numa caixa de concreto e posteriormente lançadas a montante da ponte da Estrada de Sapopemba, no Córrego Floresta.

Conforme mencionado acima são escassos os dados existentes a respeito do monitoramento das águas superficiais, principalmente em relação a qualidade das águas antes da implantação do aterro.

Em agosto de 1992, antes do início da operação do aterro, foram realizadas nas nascentes do Córrego Floresta, três análises: NASC 1, NASC 2 e NASC 3 (figura 3.16 e tabela 3.9).

Posteriormente, em dezembro de 1993, após um ano de operação do aterro, foi realizada uma outra análise na nascente de outra vertente do córrego, denominada de Asm (figura 3.16).

Sabe-se que estas amostras não são representativas para definir com precisão o background do local. Devido a escassez de dados disponíveis, estes foram utilizados com ressalvas para tentar inferir a qualidade das águas superficiais de jusante. 
A jusante, foram analisadas três amostras coletadas no Córrego Floresta logo após a confluência com a estrada de Sapobemba, que abrangeram os meses de novembro, março e junho de 1999, conforme mostra a figura 3.16 e a tabela 3.9 (Enterpa, 1998, 1999 e 2000).

A análise final das águas de jusante foram comparadas as de montante (NASC 1 a 3 e Asm) e com os padrões de potabilidade de águas, conforme mostra a tabela 3.10.

Considerando a relação diretamente proporcional entre sólidos totais dissolvidos e a condutividade, interpreta-se que as nascentes a montante do aterro, não possuem aumento na quantidade de íons dissolvidos que poderiam indicar contaminação. Comparando estes valores de montante com os dados de jusante, notamse um incremento de até 4 vezes na condutividade, o que indica um aumento brusco no conteúdo de sais dissolvidos. Este aumento é confirmado pelo teor de cloreto, que passa de $3 \mathrm{mg} / \mathrm{L}$ na água a montante para $24 \mathrm{mg} / \mathrm{L}$. nas amostras de jusante do aterro. Comportamento semelhante ocorre com sódio e ferro total.

Os dados acima sugerem que o aterro está contribuindo com sais dissolvidos na água superficial. Este aporte de íons, do ponto de vista de sólidos totais dissolvidos não é significativa, tomando-se como referencia os limites de potabilidade.

Com relação aos metais pesados, como manganês, chumbo, cádmio e bário, as águas a jusante do aterro mostram teores de 0,77 a $1 \mathrm{mg} / \mathrm{L}$ para $\mathrm{Mn}$, e 0,01 a $0,02 \mathrm{mg} / \mathrm{L}$ para $\mathrm{Cd}$, valores estes acima do permitido conforme as normas ambientais para potabilidade. Chumbo não foi detectado nas águas superficiais a jusante. Bário, com $0,1 \mathrm{mg} / \mathrm{L}$, está abaixo do limite permitido.

Os teores de nitrogênio total ( $\mathrm{N}$ kjeldahll) das águas superficiais a jusante do aterro apresentam valores de até $7,7 \mathrm{mg} / \mathrm{L}$, indicando alteração em relação ao teor de águas não contaminadas com insumos orgânicos, pois estas apresentam teores máximos entre 0,5 e $1 \mathrm{mg} / \mathrm{L}$ de $N$ total (CETESB 1998).

$O$ valor de DBO confirma a contaminação por insumos orgânicos indicada pelo $\mathrm{N}$ total, pois a água a jusante possui até $9 \mathrm{mg} / \mathrm{L}$ de DBO.

O quadro alterado das águas superficiais a jusante do aterro é completado pelo número de coliformes presentes, que chega a $4.300 \mathrm{NMP} / 100 \mathrm{ml}$.

A partir do exposto acima, conclui-se que a operação do aterro São João está contribuindo na alteração da qualidade das águas superficiais que drenam o vale hospedeiro do aterro. 


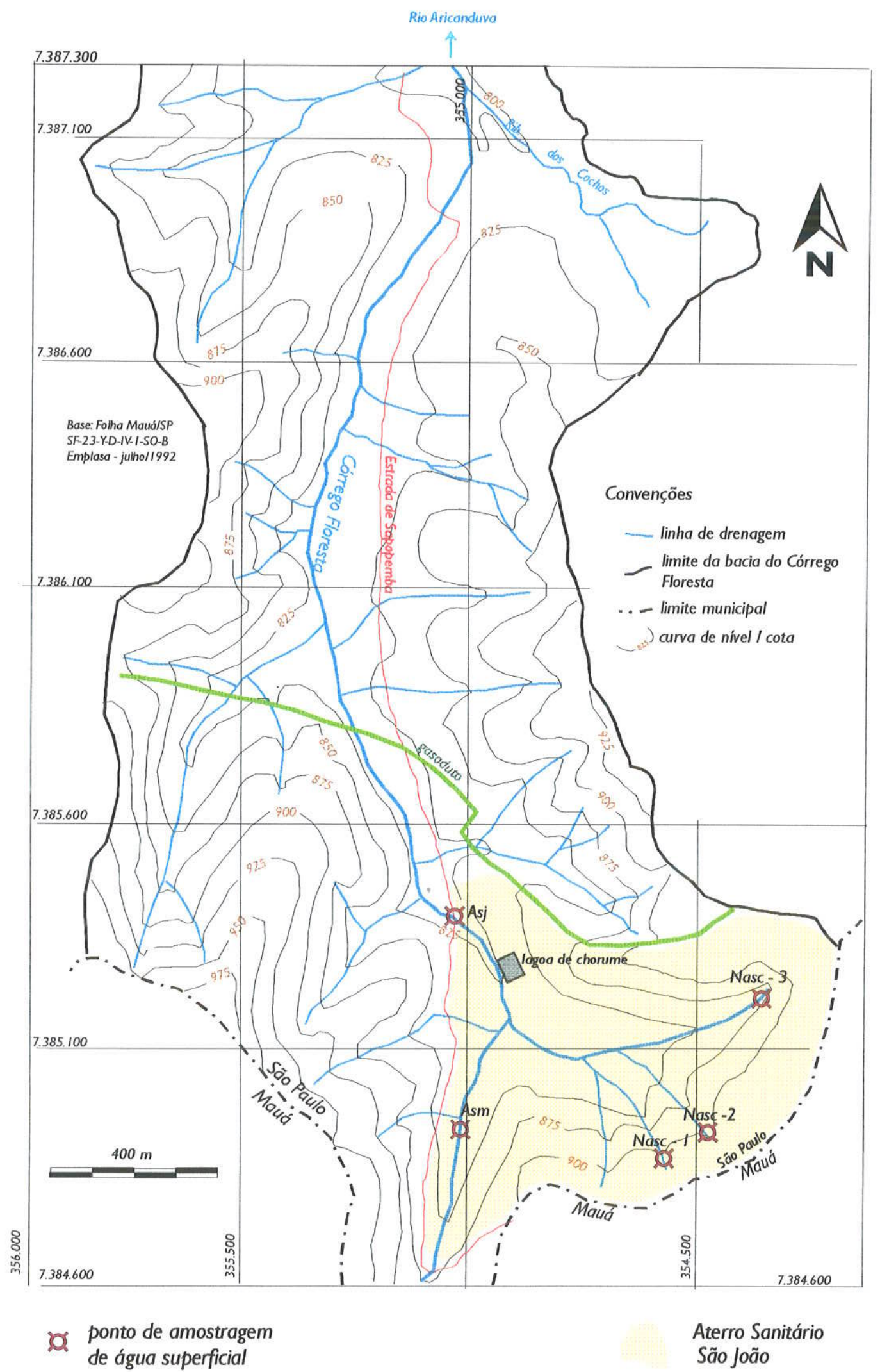

Figura 3.16 - Localização dos pontos de amostragem das águas superficiais do aterro sanitário São João, São Paulo,SP. 


\begin{tabular}{|c|c|c|c|c|c|c|c|c|}
\hline $\begin{array}{l}\text { Ponto de Amostragem } \\
\text { Data de Coleta }\end{array}$ & $\begin{array}{l}\text { NASC-1 } \\
\text { AGO. } 92\end{array}$ & $\begin{array}{l}\text { NASC } 2 \\
\text { AGO.92 }\end{array}$ & $\begin{array}{l}\text { NASC }-3 \\
\text { AGO } 92\end{array}$ & $\begin{array}{c}\text { Asm } \\
\text { dez.93 }\end{array}$ & $\begin{array}{c}\text { Asj } \\
\operatorname{dez}, 93\end{array}$ & $\begin{array}{c}\text { Asj } \\
\text { nov. } 99\end{array}$ & $\begin{array}{c}\text { Asj } \\
\text { março.00 }\end{array}$ & $\begin{array}{l}\text { Asj } \\
\text { jun.00 }\end{array}$ \\
\hline \multicolumn{9}{|c|}{ PARAMETROS FISICOS E ORGANOLEPTICOS } \\
\hline Cor Hazen ou ${ }^{\star} \mathrm{mgPt} / \mathrm{L}$ & - & & - & 10 & 20 & ${ }^{* 3} 29$ & $* 320$ & ${ }^{3} 64$ \\
\hline Condutividade $(\mu \mathrm{S} / \mathrm{cm})$ & 33,00 & 22,00 & 21,00 & 53,60 & 130,10 & 125,00 & 176,00 & 158,00 \\
\hline $\mathrm{pH}$ & 6,03 & 5,81 & 6,33 & 6,32 & 6,60 & 6,75 & 6,40 & 6,67 \\
\hline Temperatura $\left({ }^{\circ} \mathrm{C}\right)$ & - & - & - & 19,50 & 21,40 & - & 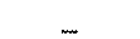 & -... \\
\hline Turbidez (UNT) & & $\ldots$ & $\ldots$ & 1 & 20 & 10 & 6 & 14 \\
\hline \multicolumn{9}{|c|}{ PARÁMETROS QUIMICOS INORGANICOS (mg/L) } \\
\hline-1 & & - & - & - & - & nd & 0,10 & 0,10 \\
\hline Cádmio & 0,005 & nd & 0,006 & 0,01 & 0,01 & 0,02 & nd & nd \\
\hline Cálcio & - & - & - & 0,50 & 5,50 & - & - & - \\
\hline Chumbo & - & - & - & - & - & nd & nd & nd \\
\hline Cromo Total & nd & nd & nd & 0,02 & $\overline{0,02}$ & nd & nd & nd \\
\hline Fosfato Total & - & - & - & - & - & nd & nd & nd \\
\hline Fósforo Total & - & - & - & 0,10 & 0,19 & - & - & - \\
\hline Mercúrio & - & - & - & - & - & nid & nd & nd \\
\hline Oxigênio Dissolvido (OD) & - & - & - & 5,00 & 4,50 & - & - & - \\
\hline Potássio & - & - & - & 1,40 & 4,50 & 2,80 & 9,80 & 8,80 \\
\hline Selênio & & - & $\ldots$ & 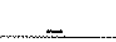 & - & nd & nd & nd \\
\hline \multicolumn{9}{|c|}{ PARAMMETROS QUIMICOS ORGÂNICOS $(\mu \mathrm{g} / \mathrm{L})$} \\
\hline Benzeno & - & - & - & - & - & 0,40 & 10,00 & 10,00 \\
\hline Etilbenzeno & - & - & - & - & - & 0,40 & 10 & 10 \\
\hline Fenóis (mg/L) & $\ldots$ & - & - & - & $\ldots$ & - & $\ldots$ & $\ldots$ \\
\hline Tolueno & - & - & - & - & - & 3,60 & 10 & 10 \\
\hline Tricloroetileno & - & - & - & - & - & 0,10 & 0,10 & 0.60 \\
\hline Xileno & - & & & - & - & 0,70 & 10,00 & 10,00 \\
\hline \multicolumn{9}{|c|}{ PARAMETROS QUIMMICOS QUE AFETAM A QUALIDADE ORGANOLEPTICA (mg/L) } \\
\hline Aluminio Total & - & - & - & - & _. & 0,78 & 0,22 & 0,16 \\
\hline Cloreto & 3,00 & $3, \overline{00}$ & 2,50 & 10,00 & 10,00 & 9,50 & 24,00 & 23.00 \\
\hline Cloreto de Metila $(\mathrm{mg} / \mathrm{kg})$ & - & - & - & - & - & 1,80 & 1,00 & 0,50 \\
\hline Cloreto de Vinila & - & - & - & - & - & 20,00 & 1,00 & 10,00 \\
\hline Cobre & - & - & - & - & - & nd & nd & nd \\
\hline DBOS & 2 & 4,00 & 1,00 & 2 & $\overline{9}$ & - & $\ldots$ & $\ldots$ \\
\hline DQO & 20 & 32,00 & 20,00 & 10 & 13 & - & - & - \\
\hline Dureza Total & $\ldots$ & $\ldots$ & - & - & - & 42,00 & 39,00 & 37,00 \\
\hline Ferro Total & 0,83 & - & $0, \overline{42}$ & 0,20 & 1,20 & 4,50 & 7,60 & 5,50 \\
\hline Magnésio & $\ldots$ & - & - & - & - & 2,30 & 4,00 & 1,90 \\
\hline Manģânes total. & $\ldots$ & - & - & - & - & 0,77 & 0,86 & 1,00 \\
\hline Nitrog. Kjeldall Total & 0,12 & $4, \overline{20}$ & 0,31 & 4,37 & 4,15 & 2,50 & 7,70 & 7,10 \\
\hline Nitrogênio Nitrato & - & - & - & - & - & 0,10 & 0,11 & 0,22 \\
\hline Nitrogennio Nitrito & - & - & $\ldots$ & - & - & 0,03 & 0,70 & nd \\
\hline Óleos e graxas & - & - & - & - & - & 7,00 & 1,00 & 6,00 \\
\hline Sódio & - & - & - & 2,10 & 6,60 & 9,60 & 9,30 & 9,20 \\
\hline Sólidos Totais Dissolvidos & $\ldots$ & - & - & m & _ & 43,00 & 158,00 & 35,00 \\
\hline Sulfato & 4,00 & 3,00 & nd & 10,00 & 10,00 & - & - & - \\
\hline Zinco & 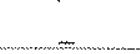 & 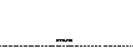 & & & & 0,08 & 0,08 & nd \\
\hline \multicolumn{9}{|l|}{ MICROBIOLOGICOS (NMP/100mI) } \\
\hline Coliformes Fecais & ausente & ausente & ausente & 2 & 240 & - & 400 & 3 \\
\hline Coliformes Totais & 13 & ausente & ausente & 2 & 240 & - & 4.300 & 460 \\
\hline Cont. Pd. Bact. Heterotrófica (ufc/ml) & - & - & - & 780 & 15.800 & - & - & - \\
\hline Pseudomonas Aeroginosa & - & - & - & - & - & ausente & $\overline{11}$ & $\overline{4}$ \\
\hline Salmonela & 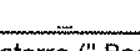 & $-\frac{1}{3 n}$ & 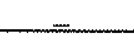 & & -5 & ausente & ausente & ausente \\
\hline
\end{tabular}

Tabela 3.9 - Dados analíticos da água superficial do aterro sanitário São João, Município de São Paulo, SP. (Adaptado de Enterpa, 1998, 1999 e 2000). 


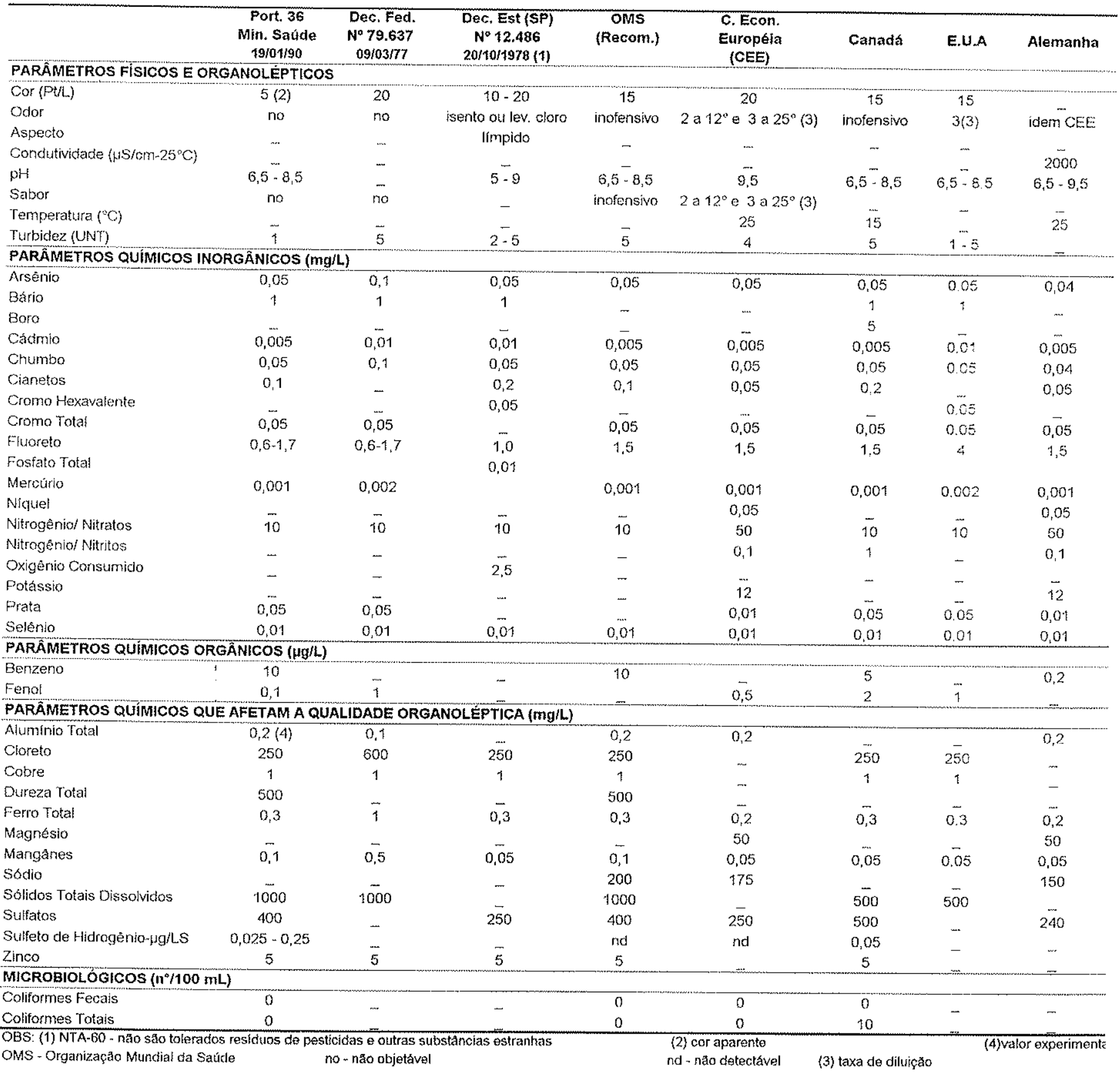

Tabela 3.10 - Padrões nacionais e intemacionais de potabilidade da água. Adaptado de Cetesb (1974) e Cetesb (1990). 


\subsubsection{Análise das águas subterrâneas}

Para avaliar a qualidade das águas subterrâneas foram analisadas as amostras coletadas em 3 poços de monitoramento de montante e 9 poços de jusante (anexo 1). As concentrações médias estão representadas na tabela 3.11 .

Nos poços de montante (PM-1, PM-2 e PM-3), as análises abrangeram amostras coletadas nos anos de 1996, 1997, 1998 e 2000, em diferentes meses do ano (Epal, 1997 e 1998, Enterpa, 1999 e 2000, conforme mostra a tabela do anexo 1. Os poços de jusante (PJ -1 a PJ -9) abrangeram amostras coletadas nos anos de 1996 a 2000 ..

Os poços de montante estão inseridos no divisor de água (figura 3.17), e teoricamente não são atingidos pela disposição de residuos, que se dá a jusante destes poços. A profundidade do nível estático destes poços varia entre 51 a 53 metros.

Os poços de jusante, estão inseridos predominantemente na porção inferior das vertentes e na planície aluvionar (figura 3.17). A profundidade do nível estático varia de 2,0 a 3,5 metros (poços PJ-1, PJ-2 e PJ-4) e entre 1,5 a 1,0 metros nos poços instalados nas porções topograficamente mais rebaixadas (PJ-5 a 9 ).

Os poços nas vertentes e divisor topográfico estão no manto intempérico. Os poços na planície estão em sedimentos aluvionares.

A avaliação da qualidade ambiental das águas subterrâneas do aterro foi determinada a partir da comparação dos poços de montante, dos poços de jusante e dos padrões de potabilidade (rabela 3.9).

Considerando os valores de sólidos totais dissolvidos (STD), condutividade, dureza total e a alcalinidade de bicarbonato (conforme expresso na tabela 3.10 ), as águas nos poços de monitoramento a jusante do aterro apresentaram valores normais e típicos de águas subterrâneas (STD de 50 a $110 \mathrm{mg} / \mathrm{L}$ ), não evidenciando nenhuma alteração de sua qualidade devido a influência do aterro. O poço a montante, por outro lado, apresenta um valor de STD (550 mg/L) muito contrastante com os poços de jusante. O mesmo ocorre com a concentração de sódio, também muito superior neste poço a montante. Interpreta-se este dado como uma indicação de contribuição de íns, provavelmente provenientes do material do aterro no poço a montante.

Com relação aos metais pesados, tanto o poço a montante, como os poços a jusante, apresentaram valores alterados em relação aos limites de potabilidade estabelecidos por padrões nacionais e internacionais.

O bário apresentou valores superiores no poço a montante (PM 01 - com 0,11 a 0,80 mg/L) e valores normais nos poços a jusante do aterro, com teores de 0,07 a $0,50 \mathrm{mg} / \mathrm{h}$, tomando como referência o limite de $1 \mathrm{mg} / \mathrm{L}$ estabelecido pelas normas ambientais. 
O cádmio apresentou teores de $0,02 \mathrm{mg} / \mathrm{L}$ no poço a montante (PM01), enquanto a jusante não foi detectado, confirmando contaminação a montante, com valores acima dos limites de 0,005 até $0,01 \mathrm{mg} / \mathrm{L}$.

Os teores de chumbo atingem até $1,7 \mathrm{mg} / \mathrm{L}$ no poço a montante e valores em torno de 0,05 $\mathrm{mg} / \mathrm{L}$ a jusante. Considerando os limites de potabilidade de 0,1 a $0,04 \mathrm{mg} / \mathrm{L}$ de $\mathrm{Pb}$, a água subterrânea, tanto a montante, como a jusante estão alteradas.

O cromo segue o comportamento acima detectado, com valores de até $0,52 \mathrm{mg} / \mathrm{L}$ no poço a montante e até $0,02 \mathrm{mg} / \mathrm{L}$ nos poços a jusante, sendo que o limite de potabilidade é de $0,05 \mathrm{mg} / \mathrm{L}$.

Os teores de cobre, manganês e zinco detectados nos poços monitorados apresentam-se dentro dos limites de potabilidade, com concentrações de 0,$7 ; 0,28$ e 1,4 mg/L, respectivamente.

O conteúdo em nitrogênio total é bastante variável nos poços, com teores desde não detectável até $6,1 \mathrm{mg} / \mathrm{L}$. Este valor alto corresponde ao poço PJ 03, localizado a jusante do aterro na planície fluvial, evidenciando presença de detritos de atividade orgânica, provavelmente oriundos do aterro ou outra fonte de esgotamento sanitário. No poço a montante o teor de nitrogênio não é detectável.

O valor de DBO oscila entre 2 e $9 \mathrm{mg} / \mathrm{L}$ nos poços a montante e entre 2 a $124 \mathrm{mg} / \mathrm{L}$ a jusante, sendo que este valor mais alto corresponde ao poço PJ 02, localizado no talvegue da drenagem principal que cruza o aterro. Estes teores claramente indicam presença de contaminação por matéria orgânica na água subterrânea, principaimente na área a jusante do aterro. Este quadro é confirmado pelos teores de coliformes totais, presentes na água subterrânea desde montante a jusante.

Teoricamente esperava-se que os poços a montante do aterro não teriam influência da infiltração proveniente do aterro, pois foram locados em situação de divisor topográfico de águas (PM 01) e na vertente acima da disposição dos resíduos (PM 02 e 03, figura 3.17). Mas, conforme os dados do monitoramento acima apresentados, verificou-se que existe contaminação dos poços a montante, muito provavelmente proveniente do aterro.

Interpreta-se este fluxo inesperado atingindo os poços em função de uma não coincidência entre o divisor topográfico e o divisor de águas subterrâneas. Nesta situação, o divisor de águas subterrâneas estaria deslocado no sentido jusante e abaixo da cobertura de resíduos. Desta maneira, a infiltração vindo da camada de resíduos atinge o divisor de águas subterrâneas onde sofre uma distribuição para montante e jusante, atingindo o poço topograficamente acima deste divisor subterrâneo. Outra hipótese seria baseada na geologia estrutural da área, caracterizada pela foliação metamórfica mergulhando em torno de $40^{\circ}$ para NW e o sistema de fraturas com direção dominante para N50-60W e mergulhos fortes para NE e SW (Epal, 1994). Neste quadro, interpreta-se que a contaminação seria dirigida no sentido SE, a montante da topografia, devido a linhas de fluxo da água subterrânea ao longo das fraturas acima citadas. Ressalta-se que estas interpretações são preliminares e que sua confirmação exigem investigações especificas, inclusive 
devido ao fato da presença de manta sintética, a qual deveria conter qualquer infiltração na área de disposição dos resíduos. 
Seleção de sítios visando a implantação de aterros sanitários com base em critérios geológicos, geomorfológicos e hidrológicos

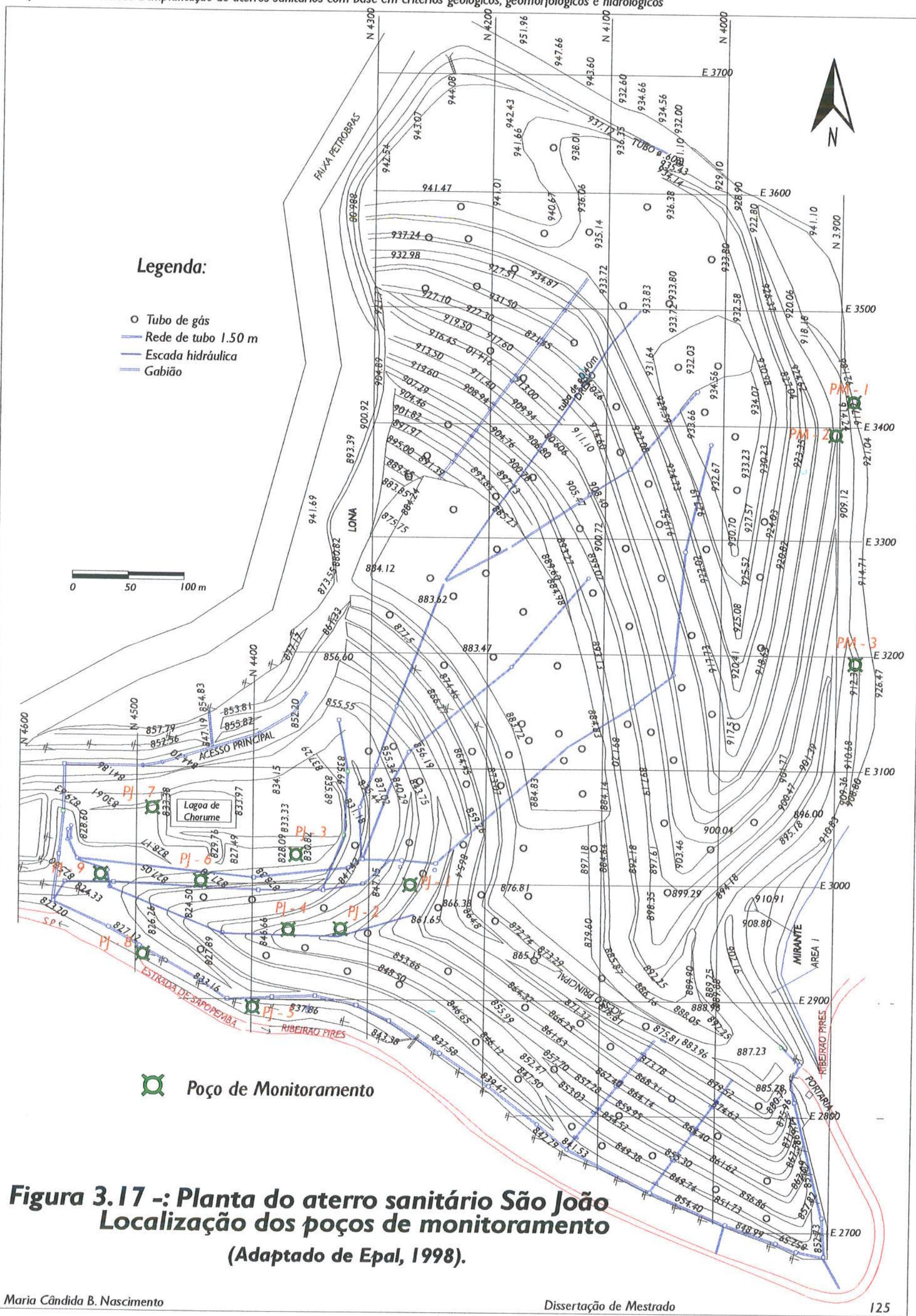




\begin{tabular}{|c|c|c|c|c|c|c|c|c|c|c|c|c|c|}
\hline Ponto de Amostragem & & PM-1 & $\mathrm{PM}-2$ & $\mathrm{PM}-3$ & PJ-1 & PJ-2 & PJ-3 & PJ-4 & PJ-S & PJ-6 & PJ-7 & PJ-8 & PJng \\
\hline & & média & média & média & média & média & & média & média & & média & média & média \\
\hline PARAMETROS FÍSICO & IS EORGAN & NOLEPTIC & $\cos$ & & & & & & & & & & \\
\hline Cor & mg PVL. & 585,80 & 66,00 & 10,25 & - & - & - & 21,0 & 13,29 & 1,00 & 107,00 & 8,29 & 32,50 \\
\hline Odor & - & - & - & & - & - & - & inod. & & inod. & inod. & & - \\
\hline Aspecto & & - & - & & - & - & - & amarl. & & limp. & amarel. & & $\ldots$ \\
\hline Condutividade & $\mu \overline{s / \mathrm{cm}}$ & 100,00 & 22,00 & 63,67 & 45,75 & 66,50 & 90,00 & 79,3 & 48,50 & 23,00 & 238,00 & 61,50 & 96,65 \\
\hline $\mathrm{pH}$ & & 5,79 & 5,71 & 6,14 & 5,37 & 5,89 & 5,49 & 6,1 & 5,28 & 5,84 & 6,91 & 5,59 & 5,78 \\
\hline Temperatura & ${ }^{\circ} \mathrm{C}$ & & 21,00 & - & 21,25 & 19,67 & - & 21,5 & $\ldots$ & - & - & - & 20,70 \\
\hline Turbidez & UNT & $13 \overline{9}, 75$ & 12,00 & 3,75 & & & & 5 & 2,86 & $\overline{1}$ & 20,00 & $3, \overline{21}$ & 14,50 \\
\hline PARAMETROS QUIMI & COS INORGI & AANICOS & & & & & & & & & & & \\
\hline Alc. Bicarbonatos & $\mathrm{mg} / \mathrm{L}$ & 67,00 & & 11,50 & - & - & . & n & 7,00 & 18,00 & $\ldots$ & 6,00 & - \\
\hline Arsênio & $\mathrm{mg} / \mathrm{L}$ & nd & nd & nd & nd & nd & 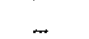 & nd & nd & nd & nd & nd & - \\
\hline Bário & $\mathrm{mg} / \mathrm{L}$ & 0,38 & 0,46 & nd & 0,14 & nd & nd & nd & 0,18 & nd & 0,12 & nd & - \\
\hline Boro & $\mathrm{mg} / \mathrm{L}$ & nd & 0,20 & nd & 0,10 & 0,095 & - & 0,18 & 0,30 & nd & nd & 4,90 & - \\
\hline Cádmio & $\mathrm{mg} / \mathrm{L}$. & 0,02 & nd & nd & nd & nd & - & nd & nd & nd & nd & nd & $0, \overline{00}$ \\
\hline Cáicio & $\mathrm{mg} / \mathrm{L}$ & - & - & - & - & - & $0, \overline{76}$ & 0,35 & - & - & - & _ & 3,70 \\
\hline Chumba & $\mathrm{mg} / \mathrm{h}$ & $0, \overline{39}$ & $0, \overline{68}$ & nd & $\overline{\text { nd }}$ & $\overline{\mathrm{nd}}$ & nd & 0,05 & 0,05 & $0, \overline{04}$ & 0,04 & $\overline{\text { nd }}$ & - \\
\hline Cianetos & $\mathrm{mg} / \mathrm{L}$ & nd & nd & nd & nd & nd & $\ldots$ & nd & nd & nd & nd & nd & $\ldots$ \\
\hline Cromo Total & $\mathrm{mg} / \mathrm{L}$ & 0,09 & 0,21 & nd & no & 0,04 & nd & nd & nd & nd & nd & nd & 0,02 \\
\hline Estanho & $\mathrm{mg} / \mathrm{L}$ & nd & nd & nó & nd & nd & - & 0,08 & nd & nd & nd & nd & $\ldots$ \\
\hline Fiuoreto & $\mathrm{mg} / \mathrm{L}$. & 0,25 & 0.19 & 0,18 & 0,30 & 0,19 & $\ldots$ & 0,06 & 0,24 & 0,10 & 0,18 & 0,25 & - \\
\hline Fosfato Total & $\mathrm{mg} / \mathrm{L}$ & 0,98 & $\ldots$ & nd & $\ldots$ & - & 0,10 & nd & nd & nd & - & 0,18 & $\ldots$ \\
\hline Fósforo & $\mathrm{mg} / \mathrm{L}$ & $\ldots$ & - & - & - & - & - & - & - & - & - & - & 0,02 \\
\hline Mercútio & $\mathrm{mg} / \mathrm{L}$ & nd & nd & nd & nd & nd & nd & nd & nd & nd & nd & nd & - \\
\hline Niquel & $\mathrm{mg} / \mathrm{L}$ & 0,09 & 0,15 & nd & 0,22 & 0,15 & - & nd & nd & nd & nd & nd & - \\
\hline Nítrogênio Nitrato & $\mathrm{mg} / \mathrm{L}$ & 0,20 & - & 0.10 & - & .. & 0,32 & nd & 0,50 & 0,35 & - & 0,25 & $\ldots$ \\
\hline Nitrogênio Nitrito & $m g / L$ & nd & - & nd & - & - & nd & nd & nd & nd & 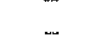 & nd & - \\
\hline Oxigênio Consumido & $\mathrm{mg} / \mathrm{L}$ & 3,10 & - & 0,65 & - & - & - & - & 1,25 & - & - & 1,05 & - \\
\hline Oxigênio Dissol.(OD) & $\mathrm{mg} / \mathrm{h}$ & - & - & $\ldots$ & - & $\ldots$ & - & - & - & 1,20 & ... & $\ldots$ & 2,30 \\
\hline Potássio & $\mathrm{mg} / \mathrm{h}$ & 1,00 & - & 1,04 & - & 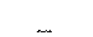 & 2,60 & 1,80 & 0,46 & 0,70 & 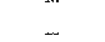 & 0,41 & 3,55 \\
\hline Prata & $\mathrm{mg} / \mathrm{L}$ & nd & $0, \overline{0} 4$ & nd & $\overrightarrow{\text { nd }}$ & $\tilde{\text { nd }}$ & - & nd & nd & nd & nd & nd & $\ldots$ \\
\hline Selênio & $\mathrm{mg} / \mathrm{L}$ & nd & nd & nd & nd & nd & nd & nd & nd & nd & nd & ind & \\
\hline PARAMETROS QUIMI & COS ORGAN & NICOS & & & & & & & & & & & \\
\hline Benzeno & $\mu \mathrm{g} / \mathrm{L}$ & 0,40 & nd & 6,80 & nd & nd & 10,00 & 10,00 & 10,00 & 0,40 & $\ldots$ & 10,00 & - \\
\hline Etil Benzeno & $\mu \mathrm{g} / \mathrm{L}$ & 0,40 & nd & 6,80 & nd & nd & 10,00 & 10,00 & 10,00 & 0,40 & - & 10,00 & - \\
\hline Fenóis & $\mathrm{mg} / \mathrm{L}$ & nd & 0,004 & nd & 0,004 & 0,005 & nd & nd & nd & nd & $\overline{\text { nd }}$ & nd & - \\
\hline Tolueno & $\mu \mathrm{g} / \mathrm{L}$ & 0,20 & nd & 6,73 & nd & nd & 10,00 & 10,00 & 10,00 & 0,50 & -. & 10,00 & $\ldots$ \\
\hline Tricloroetiłeno & $\mu g / L$ & 0,10 & nd & 0,57 & nd & nd & 10,00 & 10,00 & 0,35 & 0,10 & - & 0,80 & - \\
\hline Xilenos & $\mu \mathrm{g} / \mathrm{L}$ & 0,30 & nd & 3,47 & nd & nd & 10,00 & 10,00 & 10,00 & 0,30 & & 10,00 & \\
\hline PARÁME & COS QUE & FETAM & QUALI & IDADE O & RGANO & LEFPTIC & & & & & & & \\
\hline Aluminio Total & $\mathrm{mg} / \mathrm{L}$ & 25,00 & - & 0,24 & - & $\ldots$ & nd & nd & 0,96 & 7,90 & - & 0,53 & \\
\hline Cloreto & $\mathrm{mg} / \mathrm{L}$ & 5,00 & - & 3,17 & . & $\ldots$ & 7,00 & 4,50 & 7,50 & 2,50 & - & 6,00 & 1,50 \\
\hline Cloreto de Metila & $\mathrm{mg} / \mathrm{Kg}$ & 0,10 & - & 0,53 & - & - & - & - & 0,75 & 0,10 & 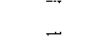 & 0,75 & ... \\
\hline Cloreto de Vinila & $\mathrm{mg} / \mathrm{L}$ & 20,00 & & 10,33 & - & - & - & - & 5,50 & 20,00 & - & 5,50 & - \\
\hline Cobre & $\mathrm{mg} / \mathrm{L}$. & 0,12 & $0, \overline{33}$ & nd & 0,005 & $0, \overline{2} 2$ & nd & 0,05 & nd & nd & $\overrightarrow{n d}$ & nd & ... \\
\hline DBOS & $\mathrm{mg} / \mathrm{L}$. & 2,00 & 4,50 & 2,00 & 2,333 & 69,67 & 2,00 & 2,25 & 2,57 & 2,00 & 6,33 & 3,43 & 9,50 \\
\hline DQO & $m g / L$. & 5,00 & 15,67 & 5,00 & nd & 225,50 & 5,00 & 5,00 & 5,71 & 5,00 & 14,67 & 7,14 & 20,50 \\
\hline Dureza Total & $\mathrm{mg} / \mathrm{L}$ & 23,00 & 22,00 & 12,33 & - & - & 25,00 & 10,00 & 5,50 & 8,00 & 50,00 & 8,00 & - \\
\hline Ferro Solúvel & $\mathrm{mg} / \mathrm{L}$ & 0,87 & 0,50 & 0,09 & $0, \overline{220}$ & 2,00 & - & 0,20 & 0,15 & 0,30 & 4,84 & 0,10 & - \\
\hline Ferro Tolal & $\mathrm{mg} / \mathrm{L}$ & 27,00 & - & 0,30 & _ & _- & 16,00 & 11,00 & 0,56 & 3,10 & 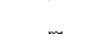 & 0,31 & 2,20 \\
\hline Magnésio & $\mathrm{mg} / \mathrm{L}$ & 5,00 & - & 1,10 & - & - & 1,10 & 0,58 & 0,31 & 0,48 & $\ldots$ & 0,27 & -. \\
\hline Mangânes Solúvel & $\mathrm{mg} / \mathrm{h}$ & 0,07 & $0, \overline{38}$ & 0,11 & 0,217 & 0,13 & & 0,17 & 0,06 & 0,05 & 0,83 & 0,11 & - \\
\hline Manganês Total & $\mathrm{mg} / \mathrm{L}$ & 0,28 & - & 0,12 & - & - & 1,00 & 0,27 & 0,09 & 0,14 & - & 0,05 & - \\
\hline Nitrog. Kjeldahl Total. & $\mathrm{mg} / \mathrm{h}$ & nd & - & 0,27 & - & - & 6,10 & 5,30 & 0,47 & nd & - & 0.44 & $1, \overline{79}$ \\
\hline Óleos e Graxas & $m g / h$ & 3,80 & 23,00 & 2,50 & 15,00 & 17,67 & 2,00 & 3,33 & 3,86 & 2,00 & 1,67 & 2,71 & m. \\
\hline Sódio & $\mathrm{mg} / \mathrm{L}$ & 18,00 & - & 2,40 & - & - & 3,70 & 2,10 & 4,40 & 2,00 & - & 3,15 & 5,30 \\
\hline Sól. Sedimentáveis & $\mathrm{m} / \mathrm{L}$ & 0,12 & $5, \overline{75}$ & 0,10 & $0, \overline{133}$ & 1,70 & - & 0,15 & 0,10 & 0,10 & 0,15 & 0,10 & $\ldots$ \\
\hline Sól. Totais Dissolv. & $\mathrm{mg} / \mathrm{h}$ & 577,00 & 1199 & 57,67 & - & ... & 110,0 & 55,00 & 68,00 & 4,00 & 233,00 & 58,50 & $\ldots$ \\
\hline Sólidos Totais & $m g / L$. & 552,00 & - & - & - & - & - & - & 50,00 & 154,0 & - & 50,00 & - \\
\hline Sulfato & $m g / L$. & 15,40 & 10,00 & 6,00 & - & - & - & 5,00 & 7,29 & 4,00 & $7, \overline{33}$ & 7.57 & 5,50 \\
\hline Sulfeto & $\mathrm{mg} / \mathrm{h}$ & nd & nd & nd & - & - & - & nd & nd & nd & nd & nd & .- \\
\hline Zinco & $\mathrm{mg} / \mathrm{h}$. & 0,29 & 0,40 & 0,07 & $0, \overline{0} 73$ & 0,10 & 0,05 & 0,06 & 0,06 & 0,14 & 0,05 & 0,46 & \\
\hline SLÓGICOS & & & & & & & & & & & & & \\
\hline Coliformes Fecais & $\mathrm{NMP} / 100 \mathrm{ml}$ & & - & 3,00 & - & -. & aus. & aus. & ats. & 1.200 & - & 4 & 155 \\
\hline Coliformes Totais & $\mathrm{NMP} / 100 \mathrm{ml}$ & 460,00 & - & 803,33 & - & - & aus. & aus. & 26 & 1.100 & - & 132 & 230 \\
\hline C.P.Bt.Heterotrófica & ufc/ml & 120,00 & -- & 25.500 & -- & $\ldots$ & aus. & aus. & 31.000 & aus. & - & 48.000 & 1.800 \\
\hline $\begin{array}{l}\text { Pseud. Aeroginosa } \\
\text { Salmonella }\end{array}$ & $\mathrm{NMP} / 100 \mathrm{ml}$ & - & - & $\begin{array}{c}122,00 \\
\text { aus }\end{array}$ & - & $\ldots$ & $\begin{array}{l}\text { aus. } \\
\text { aus. }\end{array}$ & $\begin{array}{l}\text { aus. } \\
\text { aus. }\end{array}$ & $\begin{array}{c}9 \\
\text { aus. }\end{array}$ & $\begin{array}{l}\text { aus. } \\
\text { aus. }\end{array}$ & - & $\begin{array}{c}11 \\
\text { aus }\end{array}$ & - \\
\hline
\end{tabular}

Tabela 3.11 - Dados analíticos da áqua subterrânea do aterro sanitário São João (Extraído de Epal, 1997 e Enterpa 1999 e 2000) 


\section{CONCLUSÕES E RECOMENDAÇÕES}

As referências consultadas e o estudo de casos mostram que o processo de seleção de sítios para aterros sanitários é uma das etapas mais complexas no gerenciamento de resíduos sólidos.

A situação ideal do meio físico de uma área geralmente não acompanha suas condições econômicas e sociais. A rejeição de aterros sanitários ainda é muito grande pela população, principalmente devido a desinformação sobre suas características construtivas e operacionais. Área de disposição de resíduos ainda é considerada popularmente sinônimo de mosca, mal cheiro, urubus, ratos, poluição visual, fogo e fumaça, causando a conhecida síndrome Not in My Back Yard (não no meu quintal).

A prospecção de sítios, com base em parâmetros do meio físico, visa localizar situações naturais que permitem diminuir, ou até evitar, intervenções dispendiosas de engenharia, reduzindo assim os custos totais da implantação e operação de aterros sanitários. Por outro lado, ressalta-se que as condições favoráveis do meio físico não dispensam cuidados especiais em relação a proteção do solo e das águas subterrâneas através de impermeabilização da base do aterro, drenagem e coleta do chorume e das águas pluviais, e o monitoramento geotécnico e ambiental. Como exemplo, cita-se o aterro São João, que apesar de estar localizado segundo condições favoráveis em relação às características do meio físico, apresenta problemas de alteração da qualidade das águas superficiais e subterrâneas.

Portanto, o processo de escolha de sitios deve seguir os critérios do meio físico desde a etapa de pré - seleção das áreas e proceder até a sua escolha final, como forma de prevenir a contaminação do solo e das águas.

Muitas vezes excluir sítios que apresentam condições físicas adequadas para aterros sanitários é tão fácil quanto excluir sítios que não apresentam condições de acesso ideais. Isto ainda ocorre pelo fato de que é muito mais fácil avaliar o custo da recuperação de uma estrada, do que o risco de contaminação e o conseqüente custo de remediação de uma área contaminada.

No caso do município de Juiz de Fora, lihéus e São Paulo a etapa inicial de seleção das áreas seguiu critérios físicos. Nesta etapa procurou-se prospectar sítios que apresentassem condições fisiográficas ideais, como anfiteatros inseridos em cabeceiras de drenagem (com baixa a média declividade) e em áreas de divisores de água em cotas altas.

Juiz de Fora (MG), que inicialmente apresentava maior disponibilidade de áreas para implantar aterros devido as condições de relevo e manto intempérico, mostrou, após o processo de seleção de áreas, que somente uma parcela muito restrita do municipio poderia receber um aterro sanitário. Esta restrição foi imposta principalmente pela presença de grandes áreas de preservação de mananciais. Mesmo assim, o processo seletivo indicou o Sítio Igrejinha como favorável do ponto de vista do meio físico, biótico e sócio - econômico. Por motivos desconhecidos, o aterro não foi 
implantado em nenhuma das áreas indicadas, e a forma de disposição dos resíduos no município ainda continua na forma de aterro descontrolado.

O município de llhéus (BA), que aparentemente apresentava condições ambientais desfavoráveis para a implantação de aterros devido a presença da orla marítima, manguezais, restingas e Mata Atlântica, após uma primeira análise das suas condições fisiográficas mostrou grande disponibilidade de áreas favoráveis para aterros sanitários.

Após a identificação de um conjunto de sítios favoráveis em llhéus, estes foram classificados através da aplicação de coeficientes de importância, onde os parâmetros considerados foram a distância dos sítios em relação ao centro gerador de residuos, condições de vias de acesso, vida útil do aterro sanitário, disponibilidade de solo para cobertura diária dos resíduos, ocupação atual da área, titulação da área, disponibilidade de infra-estrutura na área, características do solo, clima, e distância de área urbanas.

Nesta hierarquização de sítios foi dado pequeno peso aos parâmetros do meio físico (que se relacionam diretamente com a característica do substrato), onde o único parâmetro considerado foi denominado de "característica do solo", que correspondeu essencialmente a textura do solo. Os parâmetros mínimos necessários para avaliar a fragilidade das áreas em relação a contaminação de chorume não foram ponderados. Apesar de investigadas, não foram consideradas a espessura, granulometria e o coeficiente de permeabilidade da camada insaturada; a profundidade do nivel d' água; as estruturas geológicas (análise de fraturamento e acamamento das rochas) do embasamento rochoso; e a ocorrência de captações de águas superficiais e subterrâneas a jusante e na área de influência dos sítios. O único parâmetro relativo ao meio físico recebeu um coeficiente de importância inferior que a distância dos sítios em relação ao centro da cidade e das condições das vias de acesso. Consequentemente, as considerações à respeito da proteção do solo, das águas superficiais e subterrâneas foram transferidas para o projeto executivo do aterro.

O processo de hierarquização acima citado não considerou como indicativos ambientais os parâmetros geológicos, geomorfológicos e hidrológicos, inicialmente utilizados para a prospecção dos sítios, contrariando assim, os princípios que norteiam o processo seletivo de sítios, tema central desta dissertação. Portanto, a classificação dos sítios certamente apresentaria outra seqüência, se fossem considerados os parâmetros do meio físico.

O resultado desta hierarquização envolveu a escolha de três áreas para serem discutidas em audiência pública. Dentre estas, foi incluído o sítio Cururupe, área do lixão da cidade, que foi descartado na primeira fase de seleção de áreas devido a sua inserção em áreas alagadiças.

$\mathrm{Na}$ audiência pública ficou decidido que o aterro sanitário seria implantado no Setor Norte do município. A decisão desta audiência foi aceita e o sítio escolhido não seguiu as recomendações do meio físico, pois há carência de áreas de empréstimo e incidem afloramentos rochosos dispersos praticamente em toda a área do aterro. 
Os exemplos tratados nesta dissertação, principalmente o caso de llhéus (BA) mostram que qualquer hierarquização quantitativa com pesos e notas em processos de seleção de áreas para aterros sanitários, deve contemplar como parâmetros independentes a espessura, composição granulométrica e permeabilidade da camada insaturada; profundidade e variação do nível d' água; profundidade e grau de fraturamento do substrato rochoso; captações e uso da águas superficiais a jusante e área de influência do aterro; e captações e uso das águas subterrâneas a jusante e área de influência do aterro. Deve-se prever sempre que a contaminação do solo e das águas superficiais e subterrâneas são riscos potenciais na disposição de resíduos e portanto devem ser considerados de grande importância na atribuição de pesos.

No caso em que a escolha final de sitios para aterros sanitários esteja vinculada a apreciação pública, recomenda-se que a comunidade envolvida na questão, seja esclarecida em relação aos riscos de contaminação do solo e das águas subterrâneas e superficiais do empreendimento, caso as alternativas apontadas pela comunidade não contemplem parâmetros físicos mínimos necessários para receberem um aterro sanitário. A decisão final da audiência pública deve ser analisada pelo grupo técnico multidisciplinar que planejou e elaborou o processo seletivo de áreas, antes da tomada da decisão final.

No caso de São Paulo (SP) o processo de escolha de áreas ocorreu numa época onde as exigências ambientais eram relativamente menores, se comparadas a seleção dos sítios de llhéus e Juiz de Fora. Além deste fato, o processo de seleção foi limitado pela carência de áreas não urbanizadas e não protegidas por leis e/ou decretos. Apesar disto, os parâmetros do meio físico foram satisfatoriamente obedecidos na escolha do sitio.

No entanto, os resultados do monitoramento das águas superficiais e subterrâneas realizado no Sítio São João mostram que a qualidade dessas águas estão comprometidas pela disposição de resíduos.

De acordo com as características físicas do substrato e do projeto inicial do aterro, esperava-se a não contaminação deste sítio. Provavelmente esta contaminação é decorrente da deficiência operacional do aterro, associada ao recebimento excessivo de resíduos, pois o aterro foi concebido para receber 3.000 toneladas de resíduos por dia. Atualmente, depois de oito anos de operação, recebe diariamente cerca de $6.000 \mathrm{t} / \mathrm{dia}$.

Com base na literatura analisada e os estudos de caso nos municipios de llhéus (BA), Juiz de Fora (MG) e São Paulo (SP) é possivel propor uma seqüência metodológica que atende os requisitos mínimos do meio físico para a escolha e seleção de sítios para aterros sanitários. Recomenda-se que todo processo seletivo de áreas para aterros sanitários obedeça no mínimo o roteiro metodológico proposto na figura 4.1. 

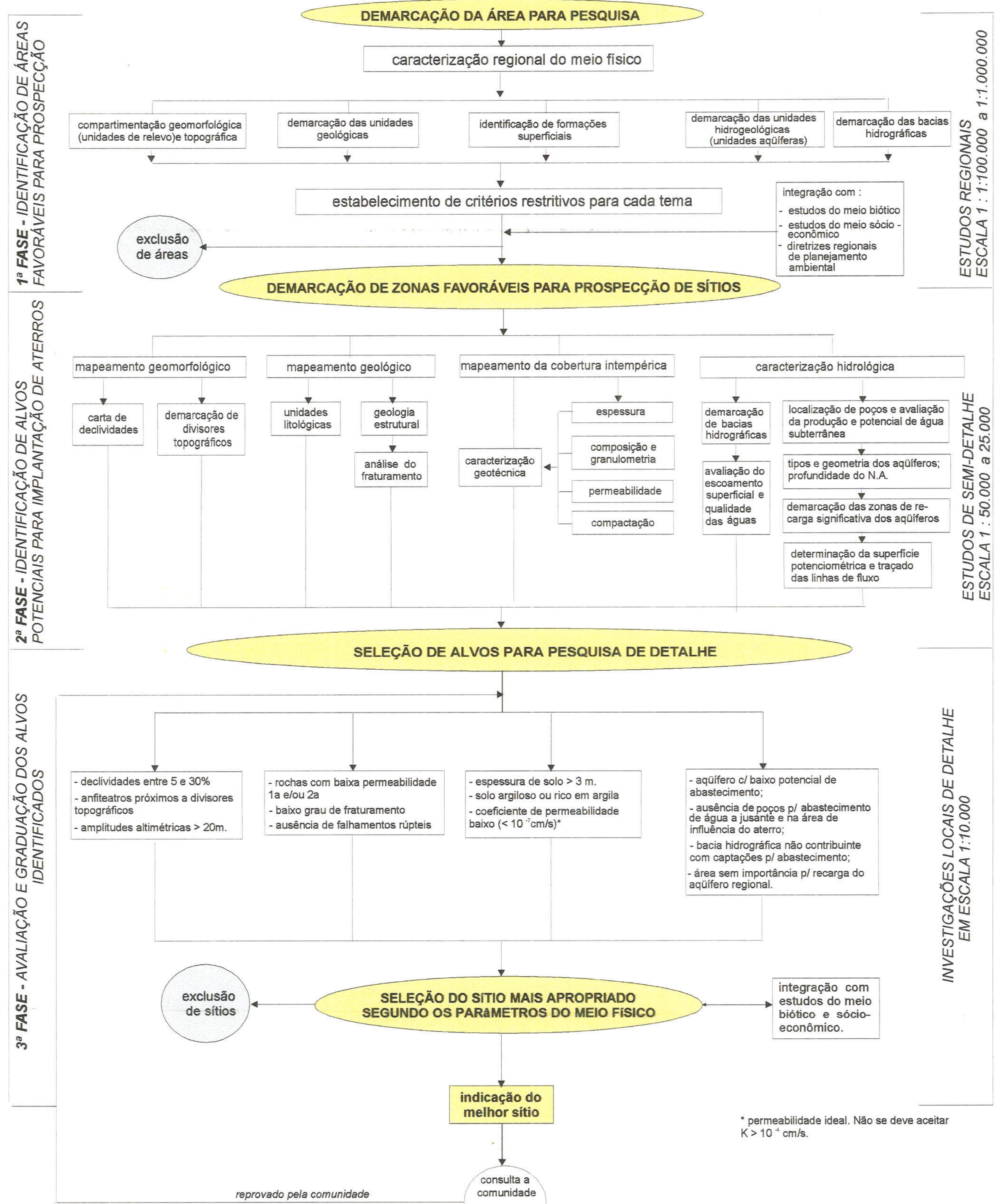

Seleção de sítios visando a implantação de aterros sanitários com base em critérios geológicos, geomorfológicos e hidrológicos

Universidade de São Paulo- Instituto de Geociências Dissertação de Mestrado 


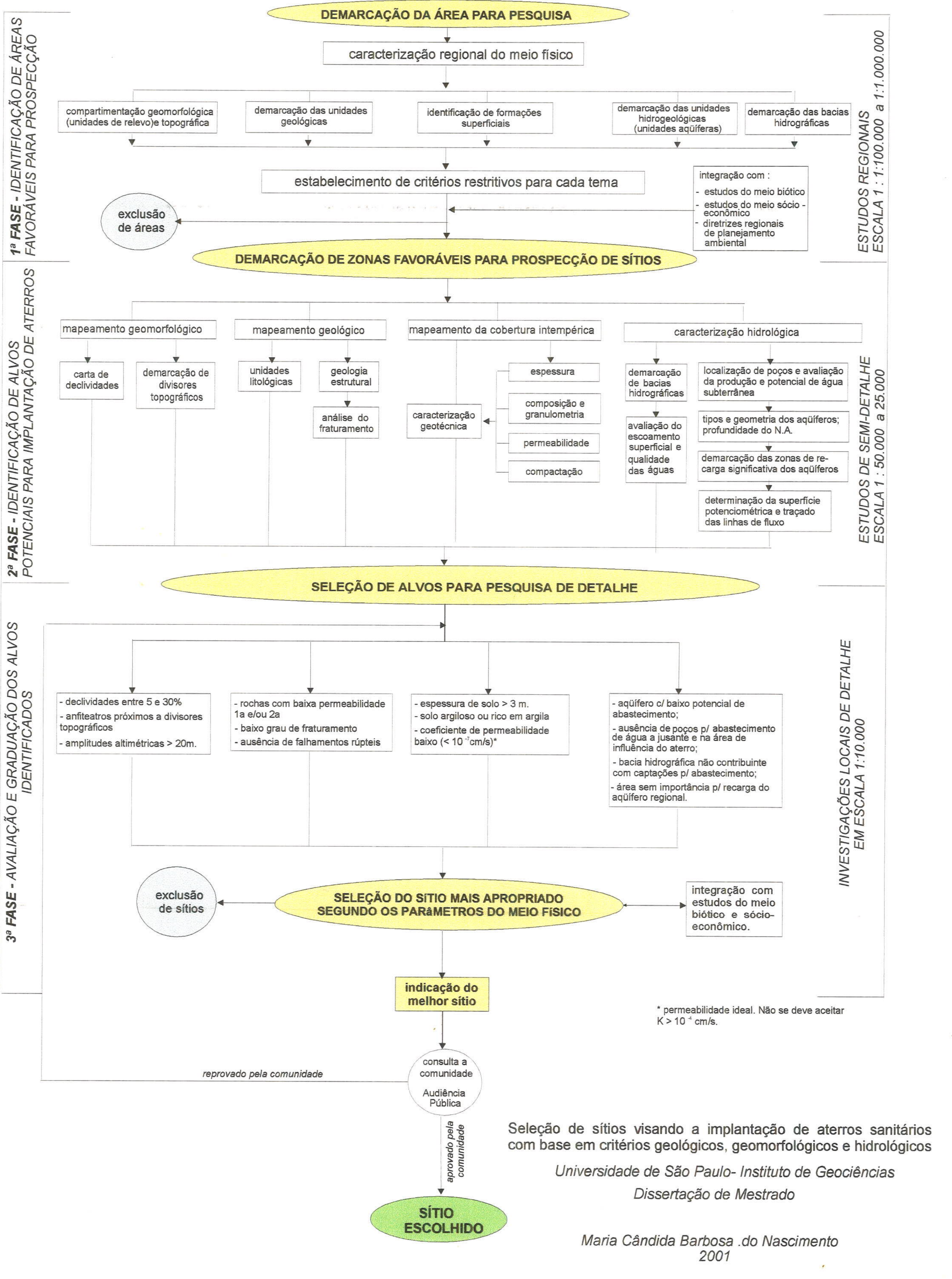

Figura 4.1 - Etapas de investigação e processos decisivos com relação ao meio físico na prospecção e seleção de sítios para aterros sanitários 


\section{REFERÊNCIAS}

ABNT - ASSOCIAÇÃO BRASILEIRA DE NORMAS TÉCNICAS. 1985. NBR 8849. Apresentação de Projetos de Aterros Controlados de Resíduos Sólidos Urbanos. 9p., São Paulo.

ABNT- ASSOCIAÇÃO BRASILEIRA DE NORMAS TÉCNICAS. 1987. NBR 10.004. Residuos Sólidos. 63p., São Paulo.

ABNT - ASSOCIAÇÃO BRASILEIRA DE NORMAS TÉCNICAS. 1990. NBR 11.174 Armazenamento de Resíduos Classes II - Não Inertes e III - Inertes. 5p., São Paulo.

ABNT - ASSOCIAÇÃO BRASILEIRA DE NORMAS TÉCNICAS. 1992. NBR 8419. Apresentação de Projetos de Aterros Sanitários de Resíduos Sólidos Urbanos. 9p., São Paulo.

ABNT - ASSOCIAÇÃO BRASILEIRA DE NORMAS TÉCNICAS. 1997 . NBR 13.896 Aterros de Resíduos Não perigosos - Critério para Projeto, Implantação e Operação. 12p., São Paulo.

AB'SABER, A.N. 1957- A geomorfologia do sítio urbano de São Paulo. Boletim da Faculdade de Filosofia Ciências e Letras, USP, 219, $34 \mathrm{p}$.

ALLOWAY, B.J. \& AYRES, D.C. 1997. Chemical principles of environmental pollution. Blackie Academic \& Professional, Second edition, 395p., London.

ALMEIDA, F.F.M. 1964 - Fundamentos geológicos do relevo paulista. Boletim do Instituto Geográfico e Geológico de São Paulo, IGG no. 41, 87p.

BAGANHA, C. 1996. Deteç̧ão e monitoramento da contaminação ambiental hidrogeológica na área de influência do aterro sanitário do Parque Santa Bárbara, Municipio de Campinas, SP. Dissertação de mestrado, Instituto de Geociências, Universidade Estadual de São Paulo, Unesp, Rio Claro, 115p.

BAGCHI, A. 1990. Design, construction and monitoring of sanitary landfills. New York: John Willey and Sons.

BARRES, M.; GRENET, Y.; MILLOT, N. \& MEISEL, A. 1990. Sanitary landfilling in France. In: Carra, J.S. \& Cossu, R. (edts) International perspectives on municipal solid wastes and sanitary landfilling. $\mathrm{Pg} .78-93$.

BEAR, J. 1972. Dynamics of fluids in porous media. Elsevier 764p., New York.

BROWN, K.W.; SCHRAB, G.E. \& DONNELLY, K.C. 1991. Acute and genetic toxicity of municipal Landfill Leachate, TR - 153, Texas Water Resources Institute, Texas A \& M. University - atenuação do chorume

BRUNNER, D.R. \& KELLER, D.J. 1972. Sanitary landfill design and operation. U.S. Environmental Protection Agency, Report SW-65ts, Washington, D.C: U.S. Government Printing Office.

CALDERONI, S. 1999 . Os bilhões perdidos no lixo. Humanitas Publicações FFLCH/USP.

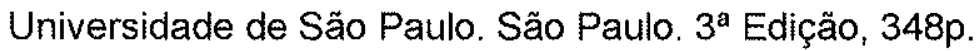

CARRA, J.S. \& COSSU, R. 1990. International perspectives on municipal solid wastes and sanitary landfilling. Academic Press Ltd., 234p., San Diego. 
CETESB- COMPANHIA DE TECNOLOGIA DE SANEAMENTO AMBIENTAL 1974. Água. Qualidade, padrões de potabilidade e poluição. Edição patrocinada por ABES/BNH/CETESB, 208p.

CETESB- COMPANHIA DE TECNOLOGIA DE SANEAMENTO AMBIENTAL 1990. Compilação de padrões ambientais. Tabelas, CETESB/SMA-SP.

CETESB - COMPANHIA DE TECNOLOGIA DE SANEAMENTO AMBIENTAL 1991.Critérios de exigência de EIA/RIMA e roteiros para sua elaboração em relação a usinas de reciclagem e/ou compostagem, aterros para resíduos sólidos domiciliares e industriais e incineradores. Manual de Orientação. Série Manuais. Governo do Estado de São Paulo, 35p.

CETESB - COMPANHIA DE TECNOLOGIA DE SANEAMENTO AMBIENTAL 1992. Aterros industriais: critérios para projeto, implantação e operação, Parte I. CETESB, Departamento de Treinamento para Ações Ambientais, apoio PROCOP, São Paulo, $255 p$.

CETESB - COMPANHIA DE TECNOLOGIA DE SANEAMENTO AMBIENTAL. 1998. Proposta de Política Estadual de Resíduos Sólidos. Série Documentos Ambientais. Secretaria do Meio Ambiente - Governo do Estado de São Paulo, 338p.

CHIAN, E.S.K. 1977. Stability of organic matter in landfill leachates. Water Research. Pergamon Press 11(2): 225-232p.

CHIAN, E.S.K \& DE WALLE, F.B.1976. Sanitary landfill leachates and their treatment. Journal of the Environmental Engineering Division, ASCE, 103 (EE2): 411-431.

CHIAN, E.S.K. \& DE WALLE, F.B.1977a. Evaluation of leachate treatment. Characterization of leachate. U.S. Environmental Protection Agency. EPA-600/2-77-186a. Vol 1, Cincinnati, Ohio.

CHIAN, E.S.K \& DE WALLE, F.B.1977b. Evaluation of leachate treatment. Characterization of Leachate. U.S. Environmental Protection Agency. EPA-600/2-77-186b. Vol II, Cincinnati, Ohio.

CHRISTENSEN, T.H. 1990. Sanitary landfilling in Denmark. In: Carra, J.S. \& Cossu, R. (edts) International perspectives on municipal solid wastes and sanitary landfilling. Pg. 37-50.

CONDER (COMPANHIA DE DESENVOLVIMENTO DA REGIÃO METROPOLITANA DE SALVADOR)/EQUIPE UMAH - URBANISMO, MEIO AMBIENTE E HABITAÇÃO S/C LTDA.1997. Estudo de impacto Ambiental e Respectivo Relatório de Impacto Ambiental. Salvador/BA. 2v. 180p.

COSSU, R \& URBINI, G. 1990. Sanitary landfilling in Italy. In: Carra, J.S. \& Cossu, R. (edts) International perspectives on municipal solid wastes and sanitary landfilling. Pg. 94 109.

COUTINHO, J.M.V. - 1979 - Mapa geológico da grande São Paulo, Emplasa, São Paulo.

COUTINHO, J.M.V. - 1980 - Relações estruturais e litológicas da Bacia de São Paulo com o Pré-cambriano circunvizinho. Aspectos Geológicos e Geotécnicos da Bacia Sedimentar de São Paulo, Publicação Especial, ABGE - SBG, São Paulo. 
CPRM-COMPANHIA DE PESQUISAS DE RECURSOS MINERAIS.1990. Projeto Santa Isabel - Mogi das Cruzes - Mauá. São Paulo. CPRM/SCTDE - Pró-Minério. V.1

CPRM-COMPANHIA DE PESQUISAS DE RECURSOS MINERAIS. 1993. Programa de Levantamentos Geológicos Básicos do Brasil. Folha Itabuna (SD.24-Y-B-VI). Estado da Bahia. Escala 1:100.000. DNPM/CPRM. 252p. Mapas

DAEE- DEPARTAMENTO DE ÁGUAS E ESGOTOS 1975. Estudos de águas subterrâneas Região Administrativa I - Grande São Paulo. Governo do Estado de São Paulo. São Paulo/SP.

DATALEGIS INFORMÁTICA LTDA E FUNDAÇÃO SOS MATA ATLÂNTICA 1996. Ecos's Legislação Ambiental. Software para consulta sobre Legislação Ambiental Brasileira. CD-ROM, São Paulo/SP.

DAVIS, M.L. \& CORNWELL, D.A. 1991. Introduction to environmental engineering. Second Edition. McGraw-Hill, Inc. New York.

DNPM - DEPARTAMENTO NACIONAL DA PRODUÇÃO MINERAL 1976. Projeto Vale do Paraíba do Sul. Relatório Final, Convênio DNPM/CPRM, Rio de Janeiro, $280 \mathrm{p}$.

DNPM - DEPARTAMENTO NACIONAL DA PRODUÇÃO MINERAL 1979. Geologia da Região Centro Oriental da Bahia. Projetos Bahia, Bahia I/ e Sul da Bahia. Relatório Integrado. DNPM/CPRM. Brasília/DF. 128p.

DEMLURB (DEPARTAMENTO MUNICIPAL DE LIMPEZA URBANA)/EQUIPE UMAH URBANISMO, MEIO AMBIENTE E HABITAÇÃO S/C LTDA. 1995. Plano Diretor de limpeza urbana do municipio de Juiz de Fora/MG. Prefeitura Municipal de Juiz de Fora/MG, Relatório, 108p..

DEPARTMENT OF THE ENVIRONMENT 1986. Landfilling wastes. A technical memorandum for the disposal of wastes on landfill sites. Waste Management Paper $N^{\circ} 26$. London Her Majesty's Stationary Office. London/England.

ENTERPA AMBIENTAL S/A 1998. Monitoramento de águas subterrâneas e superficiais do aterro São João. Análises químicas realizadas pela Ambiental Laboratórios, Tabelas, São Paulo.

ENTERPA AMBIENTAL S/A 1999. Caracterização de águas subterrâneas (poços de monitoramento) e águas superficiais (lagoa de chorume e córrego) - Aterro São João. Análises químicas realizadas pela Ambiental Laboratórios, Tabelas, São Paulo.

ENTERPA AMBIENTAL S/A 1999a. Caracterização de águas subterrâneas (poços de monitoramento) e do chorume do aterro São João, São Paulo, SP. Análises químicas realizadas pela Ambiental Laboratórios, Tabelas, São Paulo.

ENTERPA AMBIENTAL S/A 2000. Caracterização de águas superficiais (córrego)- Aterro São João. Análises químicas realizadas pela Ambiental Ltda., Tabelas, São Paulo.

ENTERPA AMBIENTAL S/A 2000a. Caracterização de águas subterrâneas (poços de monitoramento) e caixas de chorume. Análises químicas realizadas pela Ambiental Ltda., Tabelas, São Paulo.

EPAL - ENGENHEIROS ASSOCIADOS S/C LTDA. 1994. Aterro sanitário Sítio São João. Avaliação Geológica e Hidrogeológica. São Paulo/SP. 26p. Anexos. 
EPAL - ENGENHEIROS ASSOCIADOS S/C LTDA. 1997. Aterro Sanitário Sítio São João. Monitoramento do Lençol Freático. São Paulo/SP. 7p. Anexos

EPAL - ENGENHEIROS ASSOCIADOS S/C LTDA. 1998. Aterro Sanitário Sítio São João Monitoramento de Águas Subterrâneas. Características Físicas/Orgânicas. São Paulo/SP.

EQUIPE UMAH - URBANISMO, MEIO AMBIENTE E HABITAÇÄO S/C LTDA. 1990. Estudo de impacto ambiental do aterro sanitário São João - São Paulo/SP. Relatório, 127p., Barueri.

FERGUSON, R.G. 1990. Sanitary landfilling in Canada. In: Carra, J.S. \& Cossu, R. (edts) International perspectives on municipal solid wastes and sanitary landfilling. Pg. 2636.

FERREIRA, A. B. H. 1988. Dicionário Aurélio básico da língua portuguesa. Editora Nova Fronteira, 687 p., Rio de Janeiro.

FONSECA, M.J.G. 1979. Texto Explicativo - Folhas Rio de Janeiro (SF 23), Vitória (SF 24) e Iguape (SG 23), Carta Geológica do Brasil ao Milionésimo, DNPM, 65p., Brasilia.

FREEZE, R.A. \& CHERRY, J.A. 1979. Groundwater. Prentice Hall Inc. 604 p.

GAUDY, A.F \& GAUDY, E.T.1988. Elements of bioenvironmental engineering. San Jose,CA: Engineering Press, Inc.

HASUI, Y. E OLIVEIRA, M.A.F. 1984. Província Mantiqueira - setor central, In: Almeida, F.F.M. e Hasui, Y., O Pré-cambriano do Brasil, Editora Edgard Blücher, 378 pg.

HEILBRON, M. 1993. Evolução tectono-metamónfica da seção Bom Jardim de Minas MG)Barra do Piraí (RJ). Setor Central da Faixa Ribeira. São Paulo, Tese de Doutoramento, Instituto de Geociências, Universidade de São Paulo, São Paulo, 268 p.

HICSAN/ETEP (Consórcio). 1994. Plano Diretor de residuos sólidos da Região Metropolitana de São Paulo. Realizado através da CETESB - Projeto Tietê, Governo do Estado de São Paulo.

HIGESA S/A 1996. Plano diretor de recursos hídricos da região Leste (1:250.000). Relatório, Governo do Estado da Bahia, 170p.

IETC-INTERNATIONAL ENVIRONMENTAL CENTRE. 1996. International source book on environmentally sound tecnologies for municipal solid waste management. Technical Publication. Series (6). UNEP. Osaka/Shiga

INM - Instituto Nacional de Meteorologia - 1995 - Relatório climático, $5^{\circ}$ Distrito, Estação Principal de Juiz de Fora, Minas Gerais.

IPT - INSTITUTO DE PESQUISAS TECNOLÓGICAS DO ESTADO DE SÃO PAULO 1981a. Mapa geológico do Estado de São Paulo. Escala 1:500.000. Programa de Desenvolvimento de Recursos Minerais - Pró-Minério. São Paulo/SP. 2 v.

IPT - INSTITUTO DE PESQUISAS TECNOLÓGICAS DO ESTADO DE SÃO PAULO 1981b. Mapa geomorfológico do Estado de São Paulo. Escala 1:1.000.000. Programa de Desenvolvimento de Recursos Minerais - Pró-Minério. São Paulo/SP. 2v. 
IPT/CEMPRE - INSTITUTO DE PESQUISAS TECNOLÓGICAS DO ESTADO DE SÃO PAULO E COMPROMISSO EMPRESARIAL PARA RECICLAGEM. 1995. Lixo Municipal. Manual de Gerenciamento Integrado. São Paulo/SP. 277p.

KEENAN, J. D.; STEINER R.L. \& FUNGAROLI, A.A. 1983. Chemical - Physical leachate treatment. Journal of the Environmental Engineering Division, ASCE, 109 (EE6): 1371-1384.

KELLY, W.E. 1976. Groundwater pollution near a landfill. Journal of the Environmental Engineering Division, ASCE, 109 (EE6): 1189-1199.

KEMPA, E. S. \& JEDRCZAK, A. 1990. Sanitary landfilling in Poland. In: Carra, J.S. \& Cossu, R. (edts) International perspectives on municipal solid wastes and sanitary landfilling. Pg. 156-160.

KESWICK, B.H. \& GERBA, C.P. 1980. Virus in groundwater. Environmental Science and Technology, 14: 1290-1297.

LECHNER, P. 1990. Sanitary landfilling in Austria. In: Carra, J.S. \& Cossu, R. (edts) International perspectives on municipal solid wastes and sanitany landfilling. Pg. 1523, Academic Press, London.

LECKIE, J.O.; PACEY, J.G. \& HALVADAKIS, C.1979. Landfill management with moisture control. Journal of the Environmental Engineering Division, ASCE/American Society of Engineers, 105 (EE2): 337-355.

LIMPURB/EQUIPE UMAH 1990. Aterro sanitário da zona leste - relatório 1 (Localização). Relatório de Impacto Ambiental, contrato Equipe Umah/Prefeitura do Município de São Paulo, 77p.

LIMPURB/SIGIL .1997. Resíduos gerados por origem e empresa. Série Relatórios, 47p., São Paulo/SP.

LU, J.C.S.; MORISON R.D. \& STEARNS, R.J. 1984. Production and management of leachate from municipal landfills: Summary and Assessment. U.S. Environmental Protection Agency. EPA-600/2-84-92. Municipal Environmental Laboratory. Cincinnati, Ohio.

MASSAD, F. 1980. Características e propriedades geotécnicas de alguns solos da Bacia de São Paulo. Aspectos Geológicos e Geotécnicos da Bacia de São Paulo, Publicação Especial, ABGE-SBG/NSP, pg 53-93.

NOGAMI, J.S. \& VILLIBOR, D.F. 1995. Pavimentação de baixo custo com solos lateríticos. Editora Vilibor, 213 p., São Paulo.

NOGUEIRA, J.R. 1999. Evolução geológica dos terrennos de alto grau metamónfico da Faixa Ribeira na região de Juiz de Fora, Minas Gerais. Tese de Doutorameto, Instituto de Geociências, Universidade Estadual de Campinas, 190p., Campinas.

NUNES, B.T. de; RAMOS, V.L. \& DILLINGER, A.M.S. 1981. Geomorfologia. In: Projeto RADAMBRASIL. Programa de Integração Nacional. Levantamento dos Recursos Naturais. Ministério das Minas e Energia Folha SD.24. Salvador. Brasília/DF. p.123276. 
O'LEARY, P.; TANSEL, B. \& FERO, R. 1986. How to evaluate a potencial landfill site. Waste Age, 17: 78-79.

OLIVEIRA, M.A.F. 1980. Petrologia das rochas granuliticas da Faixa Paraiba do Sul, Estados do Rio de Janeiro e Minas Gerais. Tese de Doutoramento, Instituto de Geociências e Ciências Exatas, Universidade Estadual Paulista, UNESP, Rio Claro, $120 p$.

ORTH, M.H.A. \& MOTTA, F.S. 1998. Caraterização gravimétrica e físico-química dos resíduos sólidos domiciliares no Município de São Paulo. Revista Limpeza Pública (ABLP) 48: 9-16.

PEAVY, H.S.; ROWE, D.R. \& TCHOBANOGLOUS G. 1985. Environmental engineering. New York. McGraw-hill. Publishing CO.

PFEFFER, J.T.1986. Treatment of leachate from land disposal facilities proceedings of the waste. Tec. 86. Conference: Preparing Now for Tomorrow's Needs, Proceedings, vol. 1:22-24. Chicago.

PFEFFER, J.T. 1992. Solid waste management engineering. Prentice Hall. Englewood Cliffs, $152 p$.

PMSP/SSO/LIMPURB 1990. Parecer sobre a situação dos aterros sanitários no Município de São Paulo. Prefeitura do Município de São Paulo, Secretaria de Serviços e Obras e Empresa de Limpeza Urbana de São Paulo, Parecer Técnico, 32p..

QASIM, S.R. 1965. Chemical characteristics of seepage water from simulated landfills. Ph.D Thesis, West Virginia University, Morgantown, WV: p.145.

QASIM, S.R. e J.C. BUCHINAL. 1970, Leaching of polluants from refuse beds. Journal Sanitary Engineering Division, Proceedings of the American Society of Civil Engineers, 96 (SA-1):49-58.

QASIM, S.R. e CHIANG W.1994. Sanitary landfill leachate generation, control and treatment. Technomic Publishing Company - Inc. 339p.

RADAMBRASIL/Projeto. 1983. Folhas Rio de Janeiro - Vitória (geomorfologia/pedologia) MME, volume 32, 147p., Rio de Janeiro.

RAMSAY, J.G. \& HUBER, M.I.1987- The techniques of modern structural geology: Folds and Fractures. London. Academic Press, $700 \mathrm{p}$.

ROBERTSON, J. B. 1982. Chemical and nuclear wastes: different problems with different solutions? Washington: United States Geological Survey. P. 8-13.

ROBINSON, H.D. \& MARIS, P.J. 1979. Leachate from domestic waste: generation, comosition, and treatment. A review. Water Research Centre, Technical Report TR $108,37 p$.

ROCHA, A.A. \& NEDER, L.T. C. 1997. Agravos sanitários e ambientais decorrentes do tratamento e/ou disposição de resíduos sólidos nas áreas de proteção de mananciais - RMSP. Revista Limpeza Pública (ABLP), 46: 7-14.

RODRIGUEZ, S.K. 1998. Geologia urbana da Região Metropolitana de São Paulo. Tese de Doutoramento, Instituto de Geociências, Universidade de São Paulo, São Paulo, 171p. 
ROHDE, G.M. 1989. Método para seleção de áreas para aterros sanitários. Cientec. Fundação de Ciência e Tecnologia. Boletim Técnico 13. Rio Grande do Sul. 23p.

SMA - Secretaria do Meio Ambiente do Estado de São Paulo 1998. Proposta de política estadual de resíduos sólidos. Documentos Ambientais, Governo do Estado de São Paulo, 338p.

STANFORTH, R.; HAM, R. \& ANDERSON, M. 1979. Development of a synthetic municipal landfill leachate. Journal Water Pollution Control Federation, 51 (7) 1965-1975.

TCHOBANOGLOUS, G.; THEISEN, H. \& VIGIL, S. 1993. Integrated solid waste management engineering principles management issues, Mc Graw-Hill. Inc., New York.

TRESSOLTI, M. \& CONSONI, A,J. 1998. Disposição de resíduos. In: Geologia de engenharia. ABGE-Associação Brasileira de Geologia de Engenharia. Editores: Antônio Manuel dos Santos Oliveira e Sérgio Nertan Alves de Brito. São Paulo, SP. pg. $343-360$

U.S. ENVIRONMENTAL PROTECTION AGENCY. 1978. Process manual, Municipal sludge landfills, EPAm625/1-78-010, SW 705, U.S. Environmental Research Information Center, Office of Solid Waste, Washington.

VERRIER, S. J. 1990. Urban waste generation, composition and disposal in South Africa In: Carra, J.S. \& Cossu, R. (edts) International perspectives on municipal solid wastes and sanitary landfilling. Pg. 161-176. 
ANEXO 1 


\begin{tabular}{|c|c|c|c|c|c|c|c|c|c|c|c|c|c|c|c|c|c|c|c|c|c|c|c|}
\hline \multirow{2}{*}{$\begin{array}{l}\text { Ponto de Amostrage } \\
\text { Data de Coleta }\end{array}$} & \multicolumn{5}{|c|}{ PJ-01 } & \multicolumn{4}{|c|}{ PJ-02 } & PJ-03 & & & J-04 & & & & & & $\mathrm{PJ}-0 \mathrm{~S}$ & & & & \\
\hline & nov.96 & fev.97 & jum. 97 & out.97 & média & set 96 & jun. 97 & out97 & média & nov. 98 & nov.96 & fev. 97 & nov 98 & fev. 99 & média & dez.99 & jan,oof & Jlev.OL & $\operatorname{mar} 00$ & $a b r, 00 r$ & mai.00 & jun 00 & média \\
\hline PARÂMETROS FISIC & $\cos E$ & ORGAI & NOLÉF & PIICOS & & & & & & & & & & & & & & & & & & & \\
\hline Cor (mg Pt/L ou Hazel & $1-$ & - & - & - & - & - & $\sim$ & - & - & - & - & - & - & 27,0 & 21.0 & 3,00 & 8,00 & 12 & 17,00 & 3,00 & 2,00 & 48,00 & 13,29 \\
\hline Odor & - & - & - & - & $\ldots$ & $\ldots$ & - & - & - & - & $\ldots$ & - & - & inod. & inod. & pres. & inod. : & inod. & inod. & inod. & inod. & inod. & - \\
\hline Aspecto & - & - & - & $\ldots$ & - & - & - & $\sim$ & - & - & - & 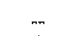 & - & amarl. & amari. & límp. & límp. '। & 'llmp. ? & nat. susi & V. ame & Iimp. & nat. sus & - \\
\hline Condutividade ( $\mu$ sict & 32,0 & 44,0 & 41,0 & 66,0 & 45,75 & $\ldots$ & 41,0 & 92,0 & 66,50 & 90,00 & 120,0 & 75,0 & 43,00 & -. & 79,3 & - & - & $\ldots$ & 18,00 & - & - & 79,00 & 48,50 \\
\hline pH & 6,12 & 5,47 & 5,12 & 4,75 & 5.37 & 6.21 & 5,76 & 5,69 & 5,89 & 5.49 & 6,64 & 6.43 & 5,36 & 5,85 & 6,1 & 4,96 & 4,56 & 5.39 & 5,78 & 4,85 & 5.07 & 6,35 & 5,28 \\
\hline Temperatura ("O) & 21,0 & 21.0 & 20,0 & 23,0 & 21.25 & 17.0 & 19,0 & 23,0 & 19,67 & - & 22,0 & 21,0 & $\ldots$ & $\ldots$ & 21,5 & - & - & $\ldots$ & $\ldots$ & $\ldots$ & - & - & $\ldots$ \\
\hline Turbidez (UNT) & & 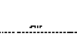 & & & & & - & - & & - & 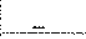 & 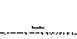 & - & 5 & 5 & 1 & 2 & 2 & 2 & 1 & 4 & 8 & 2,86 \\
\hline PARAMETROS QUIM & Aicos & INORG & ÂNIC & os lmg & & & & & & & & & & & & & & & & & & & \\
\hline Alc. Bicarbonatos & - & - & $\cdots$ & $\ldots$ & - & 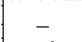 & - & - & - & - & 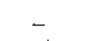 & . & 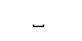 & & & - & - & - & 4,00 & - & $\ldots$ & 10,00 & 7,00 \\
\hline Arsenio & nd & nd & fnd & nd & no & $n d$ & nd & nd & nd & $\ldots$ & nd & nd & - & nd & nd & nd & nd & nd & ind & nd & nd & nd & fld \\
\hline Bátio & nd & 0.14 & nd & nd & 0.14 & nd & nd & nd & nd & nd & nd & nd & nd & nd & nd & nd & nd & nd & nd & no & 0,18 & nd & 0.18 \\
\hline Boro & 0.07 & 0,20 & nd & 0,036 & 0.10 & nd & nd & 0,095 & 0,095 & - & 0,11 & 0,24 & - & nd & 0.18 & nd & nd & nd & nd & nd & 0.30 & no & 0,30 \\
\hline Cadmio & nd & nd & $n d$ & no & nd & ind & nd & nd & nd & - & and & nd & $\ldots$ & nd & $n a^{\circ}$ & ind & nd & nd & nd & nd & nd & nd & nd \\
\hline Cálcio & - & - & - & $\ldots$ & - & $\cdots$ & $\ldots$ & $\ldots$ & $\ldots$ & 0,76 & $\ldots$ & $\ldots$ & 0,35 & $\ldots$ & 0.35 & $m$ & $\ldots$. & - & -- & m & $\ldots$ & $\ldots$ & - \\
\hline Chumbo & nd & nd & nd & nd & nd & nd & nd & nd & nd & nd & nd & nd & nd & 0,05 & 0.05 & nd & 0.05 & nd & nd & nd & no & nd & 0,05 \\
\hline Cianetos & nd & nd & nd & nd & nd & nd & nd & nd & nd & $\ldots$ & nd & ind & - & nd & $w^{2}$ & nid & nd & nd & nd & nd & na & nd & nd \\
\hline Cromo rotal & nd & nd & nd & nd & nd & nd & 0.04 & nd & $0,0 \mathrm{n}$ & nd & nd & nd & nd & nd & nd & nd & nd & nd & nd & nd & nd & nd & $\mathrm{nd}$ \\
\hline Estanho & nd & nd & nd & nd & nd & nd & nd & nd & nd & - & nd & nd & - & 0,08 & 0.08 & nd & nd & nd & nd & nd & no & nd & nd \\
\hline Fluoreto & 0,40 & nd & 0,38 & 0,12 & 0,30 & 0.22 & 0,25 & 0,10 & 0.19 & - & nd & nd & $\ldots$ & 0,06 & 0,06 & 0,56 & 0.12 & 0.07 & 0,35 & 0,20 & 0.57 & 0,20 & 0,24 \\
\hline Fosfato Total & - & - & - & - & $\cdots$ & - & - & - &.- & 0,10 & - & - & nd & - & nd & $\sim$ & - & - & nd & - & $\ldots$ & nd & nd \\
\hline Fostoro & -- & -- & $\cdots$ & -- & - & $\ldots$ & $\ldots$ & - & - & - & - & - & - & $\ldots$ & - & - & $\ldots$ & $\ldots$ & $\ldots$ & - & - & $\ldots$ & - \\
\hline Mercúria & nd & no & nd & nd & nd & nd & nd & nd & nd & nd & nd & nd & nd & nd & nd & nd & nid & nd & ind & $n i$ & nd & nd & nd \\
\hline Niquel & nd & nd & nd & 0,22 & 0,22 & nd & nd & 0.15 & 0,15 & - & nd & nd & $\ldots$ & $n d$ & nd & nd & nd & nd & nd & nos & nd & nd & nd \\
\hline Nitrogénio Nittato & $\cdots$ & ... & - & $\cdots$ & - & $\ldots$ & $\ldots$ & - & - & 0,32 & $\cdots$ & m & ná & - & nd & -. & $\ldots$ & $\ldots$ & 0,20 & - & - & 0,80 & 0,50 \\
\hline Nitrogénio Nitrito & - & . & - & - & $\cdots$ & $\ldots$ & - & -- & - & nd & - & - & nd & - & nd & - & $\ldots$ & $\ldots$ & nd & - & - & nd & nd \\
\hline Oxigenio Consumido & -- &..- & $\ldots$ &.- & - & - & $\ldots$ & - & .- & - & - & $\ldots$ & $\ldots$ & $\ldots$ & - & $\ldots$ & - & - & 1,00 & $\ldots$ & $\ldots$ & 1,50 & 1.25 \\
\hline Oxigénio Dissol (OO) &.- & - & - & - & - & - & - & - & ... & $\ldots$ & - & - & - & - & $\ldots$ & $\ldots$ & - & - & - & - & - & $\ldots$ & $\ldots$ \\
\hline Potássio & - & $\ldots$ & - & - & $\cdots$ & $\ldots$ & - & -- & - & 2,60 & - & $\sim$ & 1,80 & $\ldots$ & 1.80 & $\ldots$ & $\ldots$ & $\ldots$ & 0,43 & $\ldots$ & - & 0.49 & 0,46 \\
\hline Prata & nd & nd & nit & nd & nd & nd & nd & nd & nod & - & nd & nd & $\ldots$ & nd & nd & nd & nd & nd & nd & nd & nd & nd & $n d$ \\
\hline Selénio & nd & nd & nd & nd & nd & nd & nd & nd & nd & nd & nd & nd & nd & nd & nd & $n d$ & nd & nd & nid & nid & nd & nd & nid \\
\hline PARÁMETROS QUIM & Itcos & ORGÁ & Nicos & $\{\mu \mathrm{g} / \mathrm{L}\}$ & & & & & & & & & & & & & & & & & & & \\
\hline Benzeno & - & - & nd & - & nd & $\cdots$ & nd & - & nd & 10,00 & - & - & 10,00 & $\ldots$ & 10,00 & - & - & - & 10,00 & $\ldots$ & ... & 10,00 & 10,00 \\
\hline Etil Benzeno & - & $\ldots$ & nd & .. & nd & $\ldots$ & nd & $\ldots$ & nd & 10,00 & - & - & 10,00 & $\ldots$ & 10,00 & $\ldots$ & ... & - & 10,00 & .- & - & 10,00 & 10,00 \\
\hline Fenóis (mg/L) & nd & 0.002 & $\ldots$ & 0,005 & 0,004 & nd & $\ldots$ & 0,005 & 0,005 & nd & nd & nd & $n d$ & nid & nd & nd & nd & nd & nd & no & nd & ned & nd \\
\hline Tolueno & $\ldots$ & $\ldots$ & nd & $\ldots$ & nd & -. & nd & ... & nd & 10,00 & $\ldots$ & $\ldots$ & 10,00 & $\ldots$ & 10,00 & _- & _ & $\ldots$ & 10,00 & $\ldots$ & m & 10.00 & 10,00 \\
\hline Tricloroetileno & ـ & - & nd & - & no & .. & nd & - & nd & 10,00 & - & - & 10,00 & - & 10,00 & $\ldots$ & - & _ & 0.10 & ـ. & _ & 0,60 & 0.35 \\
\hline Xilenos & $\ldots$ & $\ldots$ & nd & & nd & & nd & - & nd & 10,00 & & & 10.00 & & 10,00 & & & & 10,00 & & & 10,00 & 10,00 \\
\hline PARĀMETROS QUIM & $\operatorname{rcos}$ & QUE Al & IFETAI & $\mathrm{MAQU}$ & ALIDAD & DE ORG & ANOLÉ & PTICA & mg/L) & & & & & & & & & & & & & & \\
\hline Aluminio Total & .. & - & - & $\ldots$ & - & - & - & - & - & nd & - & - & nd & - & nd & $\ldots$ & - & - & 0.21 & - & -- & 1,70 & 0,96 \\
\hline Cloreto & $\ldots$ & $\ldots$ & - & - & - & $\ldots$ & $\ldots$ & $\ldots$ & - & 7,00 & - & .. & 4,50 & -- & 4,50 & .. & $\ldots$ & $\ldots$ & 3,00 & $\ldots$ & $\ldots$ & 12,00 & 7.50 \\
\hline Cloreto Metila (mg/kg & - & .- & -- & $\ldots$ & $\ldots$ & $-\ldots$ & $\ldots$ & - & - & - & - & $\ldots$ & - & - & - & -- & - & $\ldots$ & 1.00 & - & $\ldots$ & 0,50 & 0.75 \\
\hline Clurelo de Vinila & $\ldots$. & $\ldots$ & $\ldots$ & - & $\ldots$ & $\ldots$. & $\ldots$ & - & $\ldots$ & $\ldots$ & $\ldots$ & $\ldots$ & $\ldots$ & $\ldots$ & $\ldots$ & $\ldots$ & $\ldots$ & $\ldots$. & 1.00 & .- & $\ldots$ & 10,00 & 5.50 \\
\hline Cobre & nd & 0,005 & nd & nd & 0,005 & 0.19 & 0.25 & nd & 0,22 & nd & nd & 0.05 & nd & nd & 0,05 & nd & nd & nd & nd & nd & nd & nd & nd \\
\hline$D B O B$ & 2,00 & 3,00 & nd & 2,00 & 2,333 & 83,00 & 124,0 & 2,00 & 69,67 & 2,00 & 2,00 & 3,00 & 2,00 & 2,00 & 2,26 & 6,00 & 2,00 & 2,00 & 2,00 & 2,00 & 2,00 & 2,00 & 2,57 \\
\hline DQO & nd & nd & nd & nd & nd & 148,0 & 303,0 & nd & 225,50 & 5,00 & nd & no & 5,00 & 5,00 & 5,00 & 10.00 & 5,00 & 5,00 & 5,00 & 5,00 & 5,00 & 5,00 & 5,71 \\
\hline Dureza & - & $\ldots$ & - & - & - & .- & - & ـ & - & 25,00 & - & - & 10,00 & - & 10,00 & .. & $\ldots$ & - & 6,00 & - & $\ldots$ & 5,00 & $\$, 50$ \\
\hline Ferro Solúvel & nd & nd & 0,22 & nd & 0,220 & 1,40 & 2,60 & nd & 2,00 & - & nd & nd & - & 0,20 & 0,20 & 0,06 & $n d$ & 0.06 & nd & 0,09 & nd & 0,37 & 0.15 \\
\hline Ferro Tolal & - & - & - & $\ldots$ & .. & .- & - & - & - & 16,00 & $\ldots$ & .. & 11,00 & $\ldots$ & 11,00 & $\ldots$ & - & - & 0,22 & -. & .. & 0,90 & 0,56 \\
\hline Magnesio & - & - & - & - & $\ldots$ & _- & - & $\ldots$ & $\ldots$ & 1,10 & .. & - & 0,58 & - & 0,58 & $\ldots$ & $\ldots$ & $\ldots$ & 0,44 & _- & $\ldots$ & 0,17 & 0,31 \\
\hline Mangánes Solúvel & 0,10 & 0,35 & nd & 0,20 & 0,217 & 0,18 & nd & 0,07 & 0,13 & $\ldots$ & 0,12 & 0.15 & .- & 0,24 & 0,17 & - & nd & nd & 0,06 & nd & nd & 0,06 & 0.06 \\
\hline Manganęs Total & $\ldots$ & . & - & - & - & - & - & - & - & 1,00 & - & - & 0.27 & $\ldots$ & 0.27 & . & .. & -- & 0,09 & - & - & nd & 0,09 \\
\hline Nitrog. Kjeddanl Total & - & - & $\ldots$ & $\ldots$ & - & - & - & - & - & 6,10 & - & $\ldots$ & 5,30 & - & $\$, 30$ & - & $\ldots$. & $\ldots$ & nd & $\ldots$ & $\ldots$ & 0,47 & 0,47 \\
\hline Óleos e Graxas & nd & nd & nd & 15,00 & 15,00 & 13,00 & 35,00 & 5,00 & 17,67 & 2,00 & nd & 4,00 & 4,00 & 2,00 & 3,33 & 6.00 & 7,00 & 2,00 & 2,00 & 2,00 & 4,00 & 4,00 & 3,86 \\
\hline Sodio & $\ldots$ & - & - & - & - & - & $\ldots$ & - & ... & 3,70 & $\ldots$ & - & 2,10 & - & 2,10 & -_ & - & -- & 1,70 & -- & - & 7,10 & 4.40 \\
\hline Sol. Sedimentávés (n & 0,20 & 0,10 & nd & 0.10 & 0.133 & 1,50 & 0,60 & 3,00 & 1,70 & - & 0,20 & 0,10 & - & ${ }^{n}$ & 0,15 & 0,10 & 0,10 & 0.10 & 0,10 & 0.10 & 0,10 & 0.10 & 0,10 \\
\hline Sól. Totais Dissolv. & - & - & - & - & - & - & $\ldots$ & $\ldots$ & - & 110,0 & $\ldots$ & $\ldots$ & 55,00 & - & 55,00 & - & $\ldots$ & ـ & 42,00 & .. & $\ldots .$. & 94,00 & 68.00 \\
\hline Solidos Totais & $\ldots$ & - & - & - & $\ldots$ & $\ldots$ & $\ldots$ & $\ldots$ & - & $\ldots$ & - & $\cdots$ & m & $\cdots$ & $\ldots$ & $\ldots$ & $\ldots$ & - & 50,00 & $\ldots$ & w. & $\ldots$ & 50,00 \\
\hline Suffato & $\ldots$ & $\ldots$ & $\ldots$ & - & m & $\ldots$ & $\ldots$ & - & $\ldots$ & $\ldots$ & - & - & - & 5.00 & 5,00 & 16,00 & 5,00 & 8,00 & 8,00 & 3,00 & 6,00 & 5,00 & 7.29 \\
\hline Suffeto & - & - & $\ldots$ & .. & - & .- & - & - & - & - & - & - & - & nd & nd & nid & nd & nd & nd & nd & nd & nd & nd \\
\hline Zinco & 0.07 & 0.07 & 0,05 & 0.10 & 0,073 & 0,12 & 0,08 & 0,11 & 0.10 & 0,05 & 0,03 & 0.04 & 0,07 & 0,09 & 0,06 & 0,04 & 0,05 & 0,05 & nd & nd & 0,08 & 0,06 & 0,06 \\
\hline MICROBLOLOGICOS & (NMP) & $1100 \mathrm{ml}$ & & & & & & & & & & & & & & & & & & & & & \\
\hline Colifomes Fecais & - & - & $\ldots$ & - & - & - & - & - & - & aus. & - & - & aus. & - & aus. &.- & ... & .... & aus. & $\ldots$ & .. & atss. & aus. \\
\hline Coliformes Totais & $\ldots$ & -. & $\ldots$ & $\ldots$ & $\ldots$ & - & $\ldots$ & -- & - & aus. & -- & $\ldots$ & aus. & - & aus. & $\ldots$ & $\ldots$ & $\ldots$ & 43 & $\ldots$ & $\ldots$ & 9 & 26,00 \\
\hline C.P.Bt.Hetero. (ufc/ml & $\ldots$ & -. & -.- & - & $\ldots$ & $\ldots$ & .. & $\cdots$ & $\ldots$ & aus. & . & $\ldots$ & aus. & $\ldots$ & aus. & $\ldots$ & $\ldots$ & $\ldots$ & 48.000 & $\ldots$ & $\ldots$ & 14.000 & 31000 \\
\hline Pseud. Aeroginosa & $\ldots$ & - & - & - & - & - & -- & $\ldots$ & $\ldots$ & aus. & .. & .- & aus. & $\ldots$ & aus. & $\ldots$ & $\ldots$ & -- & 3 & $\ldots$ & $\ldots$ & 15 & 9.00 \\
\hline $\begin{array}{l}\text { Salmonella } \\
- \text { - resultado não obticio }\end{array}$ &.$\overline{\mathrm{Col}}$ & 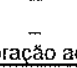 & entu & $a$ & - & - & - & - & - & aus. & - & $\ldots$ & aus. & - & aus. & m & $\ldots$ & - & aus. & - & $\ldots$ & aus. & aus. \\
\hline
\end{tabular}

Dados analíticos da água subterrânea do aterro São João, São Paulo (SP). 


\begin{tabular}{|c|c|c|c|c|c|c|c|c|c|c|c|c|c|c|c|c|}
\hline \multirow{2}{*}{\multicolumn{2}{|c|}{$\begin{array}{ll}\text { Ponto de Amostragen } & \text { PJ-06 } \\
\text { Data de Coleta } & \text { nav.99 }\end{array}$}} & \multicolumn{4}{|c|}{ PJ-07 } & \multicolumn{8}{|c|}{ PS-08 } & \multicolumn{3}{|c|}{ PJ-9 } \\
\hline & & fev. 99 & mai.99 & ago.99 & média & dez.99 & jan.00 & fevoo & $\operatorname{mar} .00$ & $a b r .00$ & mai.00 & jun.00 & média & dez.93 & jan.94 & média \\
\hline \multicolumn{17}{|c|}{ PARAMETROS FISICOS E ORGANOLEPTICOS } \\
\hline Cor (mg Pthl. ou Hazen; & 1,00 & 12,00 & - & 202,00 & 107,00 & 3,00 & 11,00 & 8,00 & 12,00 & 3,00 & 1.00 & 20,00 & 8,29 & 40,00 & 25,00 & 32,50 \\
\hline Odor & inod. & mod. & - & inod. & inod. & pres. & inod. & inod. & inod. & inod. & inod. & inod. & & - & - & $\ldots$ \\
\hline Aspecto & limp. & amarel. & - & amarel. & amarel. & limp. & limp. & $\operatorname{limp}$ & nat. suse & ov. arnar & $\operatorname{limp}$ & mat sus. & & - & - & - \\
\hline Condutividade ( $\mathrm{H} / \mathrm{cm}$ ) & 23,00 & - & 238,00 & - & 238,00 & - & - & - & 38.0 & - & - & 85.0 & 61,50 & 113,4 & 79.9 & 96,65 \\
\hline $\mathrm{pH}$ & 5.84 & 6,50 & 6,36 & 7,86 & 6,91 & 5,04 & 5,09 & 5,66 & 5,91 & 5,61 & 5,68 & 6.13 & 5,59 & 5,74 & 5,82 & 5.78 \\
\hline Temperalura (:C) & $\ldots$ & - & $\ldots$ & u & - & - & - & -. & $\ldots$ & - & - & - & ... & 20.7 & 20.7 & 20.70 \\
\hline Turbidez (UNT) & 1 & 2 & & 38 & 20,00 & 1 & 3 & 1 & 4 & 1 & 1 & 12 & 3,21 & 20 & 9 & 14,50 \\
\hline \multicolumn{17}{|c|}{ PARAMETROS QUIMICOS INORGÂNICOS (mg/L) } \\
\hline Alc. Bicarbonatos & 18,00 & - & $\sim$ & - & .. & - & - & - & 5,00 & - & - & 7,00 & 6,00 & - & - & $\ldots$ \\
\hline Arsênio & nd & nd & nd & nd & nd & nd & nd & nd & nd & nd & nd & nd & nd & $\ldots$ & $\ldots$ & - \\
\hline Bário & nd & 0,17 & 0,07 & nd & 0,12 & nd & nd & nd & nd & nd & nd & nd & nd & - & - & - \\
\hline Boro & nd & nd & nd & nd & nd & nd & nd & nd & nd & nd & 4,90 & nd & 4,90 & - & - & $\ldots$ \\
\hline Cádmio & nd & nd & nd & nd & nd & nd & nd & nd & nd & no & nd & nd & nd & 0,00 & 0,00 & 0,00 \\
\hline Cálcio & - & - & - & - & - & - & $\ldots$ & - & - & - & $\ldots$ & $\ldots$ & - & 4,20 & 3,20 & 3,70 \\
\hline Chumbo & 0,04 & 0,06 & 0,02 & nd & 0,04 & nd & nd & nd & nd & nd & nd & nd & nd & $\ldots$ & -- & $\ldots$ \\
\hline Cianetos & nd & nd & nd & nd & nd & nd & nd & nd & nd & nd & not & $n d$ & nd & - & $\ldots$ & - \\
\hline Cromo Total & nd & nd & nd & nd & nd & nd & nd & nd & nd & nd & nd & nd & nd & 0,02 & - & 0.02 \\
\hline Estanho & nd & nd & nd & nd & fid & nd & nd & nd & nd & nd & nd & nd & nd & - & .. & - \\
\hline Fluoreto & 0.10 & 0,06 & $0,2 A$ & 0,24 & 0.18 & 0,37 & 0.17 & 0,10 & 0,40 & 0,27 & 0,25 & 0,22 & 0,25 & $\ldots$ & $\ldots$ & - \\
\hline Fosfato Total & nd & - & - & $\ldots$ & $\ldots$ & - & - & - & nd & - & $\ldots$ & 0,18 & 0.18 & - & - & $\ldots$ \\
\hline Fósforo & m & $\ldots$ & -. & - & - & $\ldots$ & $\ldots$ & $\ldots$ & $\ldots$ & - & - & $\ldots$ & - & 0,02 & 0,02 & 0,02 \\
\hline Mercúrio & nd & nd & nd & nd & nd & nd & nd & nd & nd & nd & nd & nd & nd & $\ldots$ & .. & - \\
\hline Niquel & no & nd & nd & nd & nd & nd & nd & nd & nd & nd & nd & nd & nd & - & - & .. \\
\hline Nitrogênio Niträto & 0,35 & $m$ & - & -- & $\cdots$ & $m$ & $\cdots$ & - & 0,40 & - & 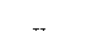 & 0,10 & 0,25 & - & -. & $\ldots$ \\
\hline Nitrogênio Nittrito & nd & $\ldots$ & - & - & - & - & $\ldots$ & .. & nd & - & - & nd & nd & $\ldots$ & - & - \\
\hline Oxigenio Consumido & - & - & - & . & $\ldots$ & - & -- & $\ldots$ & 0,80 & $\ldots$ & - & 1,30 & 1.05 & - & $\ldots$ & - \\
\hline Oxigentio Dissol. (OD) & 1,20 & $\ldots$ & - & $\ldots$ & - & - & - & - & - & - & $\ldots$ & - & - & 2,30 & 2,30 & 2,30 \\
\hline Potássio & 0.70 & - & $\ldots$ & - & $\ldots$ & $\ldots$ & - & - & 0,35 & $\ldots$ & $\ldots$ & 0,47 & 0,41 & 3,70 & 3.40 & 3.55 \\
\hline Prata & nd & nd & nd & nd & nd & nd & nd & ind & nd & $n d$ & nd & nd & nd & - & $\ldots$ & - \\
\hline Selênio & nid & nd & nd & nd & nd & nd & nd & nd & nd & ned & nd & nd & nd & & & \\
\hline PARAMETROS QUIMIO & COS OR & GANICO & $S\left(\mu / g^{\prime L}\right)$ & & & & & & & & & & & & & \\
\hline Benzeno & 0,40 & - & - & $\ldots$ & $\ldots$ & $\cdots$ & $\ldots$ & - & 10,00 & - & $+r$ & 10,00 & 10,00 & $\ldots$ & - & - \\
\hline Etil Benzeno & 0,40 & $\ldots$ & - & - & $\cdots$ & $m$ & $\ldots$ & $\ldots$ & 10,00 & - & - & 10,00 & 10,00 & - & $\ldots$ & - \\
\hline Fenóis (mg/L) & nd & nd & nd & nd & nd & nd & nd & nd & nd & nd & nd & nd & nd & - & - & $\ldots$ \\
\hline Tolueno & 0.50 & $\ldots$ & $\cdots$ & $\ldots$ & $\cdots$ & -- &.- & $\cdots$ & 10,00 & - & $w$ & 10,00 & 10,00 & $\ldots$ & $\ldots$ & - \\
\hline Tricloroetileno & 0,10 & - & - & $\ldots$ & - & - & - & - & 1,00 & - & - & 0,60 & 0,80 & n. & - & - \\
\hline Xilenos & 0,30 & - & $\ldots$ & - & & & $=$ & 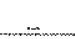 & 10,00 & & & 10,00 & 10,00 & & & $\ldots$ \\
\hline PARAMMETROS QUIMIC & $\cos Q$ & E AFETA & $A M A Q U$ & JALIDAD & EE ORGA & NOLEPT & ICA (mg & $g(h)$ & & & & & & & & \\
\hline Aluminio Total & 7.90 & $\ldots$ & - & - & - & - & -- & - & 0.32 & - & $\ldots$ & 0,73 & 0,53 & .. & - & - \\
\hline Cloreto & 2,50 & - & $\ldots$ & $\ldots$ & $\ldots$ & $\ldots$ & - & - & 8,50 & - & - & 3.50 & 6,00 & 1,00 & 2.00 & 1,50 \\
\hline Cloreto Metila ( $m g / \mathrm{Kg}$ ) & 0,10 & - & - & $\ldots$ & - & - & - & $\ldots$ & 1,00 & - & - & 0,50 & 0.75 & - & - & - \\
\hline Cloreto de Vimisa & 20,00 & $\ldots$ & $\ldots$ & - & $\ldots$ & $\ldots$ & $\ldots$ & $\ldots$ & 1,00 & $\ldots$ & $\ldots$ & 10,00 & 5,50 & $\ldots$ & $\ldots$ & $\ldots$ \\
\hline Cobre & nd & nd & nd & nd & nd & nd & nod & no & nd & nd & nd & nd & nd & - & - & - \\
\hline DBOS & 2,00 & 2,00 & 9,00 & 8,00 & 6,33 & 12,00 & 2,00 & 2,00 & 2,00 & 2,00 & 2.00 & 2,00 & 3,43 & 14,00 & 5,00 & 9,50 \\
\hline 1000 & 5,00 & 5,00 & 24,00 & 15,00 & 14,67 & 20,00 & 5,00 & 5,00 & 5,00 & 5,00 & 5.00 & 5,00 & 7,14 & 26,00 & 15,00 & 20,50 \\
\hline Dureza Tolal & 8,00 & $\ldots$ & 50,00 & - & 50,00 & - & - & - & 6.00 & - & - & 10,00 & 8,00 & - & -. & - \\
\hline Ferro Soluvel & 0,30 & 0,23 & 4,28 & 10,00 & 4,84 & 0,12 & nd & 0.11 & nd & 0,06 & 0,08 & 0,14 & 0.10 & - & - & - \\
\hline Fetro Tolal & 3,10 & $\ldots$ & $\ldots$ & - & - & - & $\ldots$ & -. & 0.22 & $\ldots$ & $\ldots$ & 0.40 & 0,31 & 1,50 & 2,90 & 2,20 \\
\hline Magnésio & 0.48 & - & $\ldots$ & - & - & - & - & .. & 0,23 & $\ldots$ & - & 0,31 & 0,27 & $\ldots$ & $\ldots$ & $\ldots$ \\
\hline Manganes Soluvet & 0,05 & 0,10 & 1,09 & 1,30 & 0,83 & $\ldots$ & - & 0,16 & nd & nd & nd & 0,06 & 0.11 & - & - & - \\
\hline Manganés Tota! & 0,14 & - & - & - & $\ldots$ & $\ldots$ & - & - & nd & - & - & 0.05 & 0.05 & - & - & - \\
\hline Nitrog. Kjeldahi Total & nd & - & - & - & - & - & ... & _ & 0,07 & $\ldots$ & $\ldots$ & 0,80 & 0.44 & 0,07 & 3,50 & 1,79 \\
\hline Óleos e Graxas & 2,00 & 2,00 & 2,00 & 1,00 & 1,67 & 1,00 & 2,00 & 1,00 & 1,00 & 4,00 & 4,00 & 6,00 & 2,71 & - & - & - \\
\hline Sodio & 2,00 & - & - & - & - & - & - & - & 4,90 & - & - & 1,40 & 3,15 & 5,50 & 5,10 & 5,30 \\
\hline Sol. Sedimentáveis (m) & 0,10 & * & 0,10 & 0.20 & 0,15 & 0,10 & 0,10 & 0,10 & 0,10 & 0,10 & 0,10 & 0,10 & 0,10 & - & - & - \\
\hline Sól. Totais Dissolv. & 4,00 & .- & 233,00 & $\ldots$ & 233,00 & $\ldots$ & $\ldots$ & $\ldots$ & 42,00 & $\ldots$ & $\ldots$ & 75,00 & 58,50 & - & - & $\ldots$ \\
\hline Sólidos Totais & 154,0 & - & - & $\ldots$ & $\ldots$ & $\ldots$ & - & $\ldots$ & 50,00 & - & $\ldots$ & $\ldots$ & 50,00 & - & - & - \\
\hline Sulfato & 4,00 & 5,00 & 7,00 & 10,00 & 7,33 & 15,00 & 5,00 & 8,00 & 7,00 & 3,00 & 8.00 & 7.00 & 7,57 & 1,00 & 10,00 & 5,50 \\
\hline Sulfeto & nd & nd & nd & nd & nd & nd & nd & nd & nid & nd & nd & nd & nd & - & - & $\ldots$ \\
\hline Zinco & 0,14 & nd & 0.04 & 0,06 & 0,05 & 0,06 & 0,05 & 0,06 & 0,06 & nd & 2,40 & 0,15 & 0,46 & & & \\
\hline MICROBIOLOGGLOS (N & NMP/100 & $\theta \mathrm{mll}$ & & & & & & & & & & & & & & \\
\hline Coliformes Fecais & 1.200 & - & - & - & - & - & - & - & aus. & - & - & 4 & 4,00 & 300 & 10 & 155,00 \\
\hline Coliformes Totais & 1.100 & $\ldots$ & -- & $\ldots$ & -- & $\ldots$ & $\ldots$ & $\ldots$ & 23 & $\ldots$ & $\ldots$ & 240 & 131,50 & 400 & 60 & 230,00 \\
\hline C.P.Bt.Hetero. (ufc/ml) & aus. & $\ldots$ & -- & $\cdots$ & $\cdots$ & ... & $\ldots$ & $\ldots$ & 80.000 & $\ldots$ & $\ldots$ & 16.000 & 48000 & 1.800 & $\ldots$ & 1800 \\
\hline Pseud. Aeroginosa & aus. & $\ldots$ & $\ldots$ & - & $\ldots$ & $\ldots$ & - & $\cdots$ & aus. & - & - & 11 & 11,00 & - & - & $\ldots$ \\
\hline $\begin{array}{l}\text { Salmonella } \\
\text { - resuttado năo obtido. }\end{array}$ & $\begin{array}{l}\text { aus. } \\
\text { Coloraces }\end{array}$ & a acentu & uadà & - & - & - & $\ldots$ & - & aus. & - & - & aus. & aus & - & - & $\ldots$ \\
\hline
\end{tabular}

Dados analíticos da água subterrânea do aterro São João, São Paulo (SP), continuação . 